Historic, Archive Document

Do not assume content reflects current scientific knowledge, policies, or practices. 



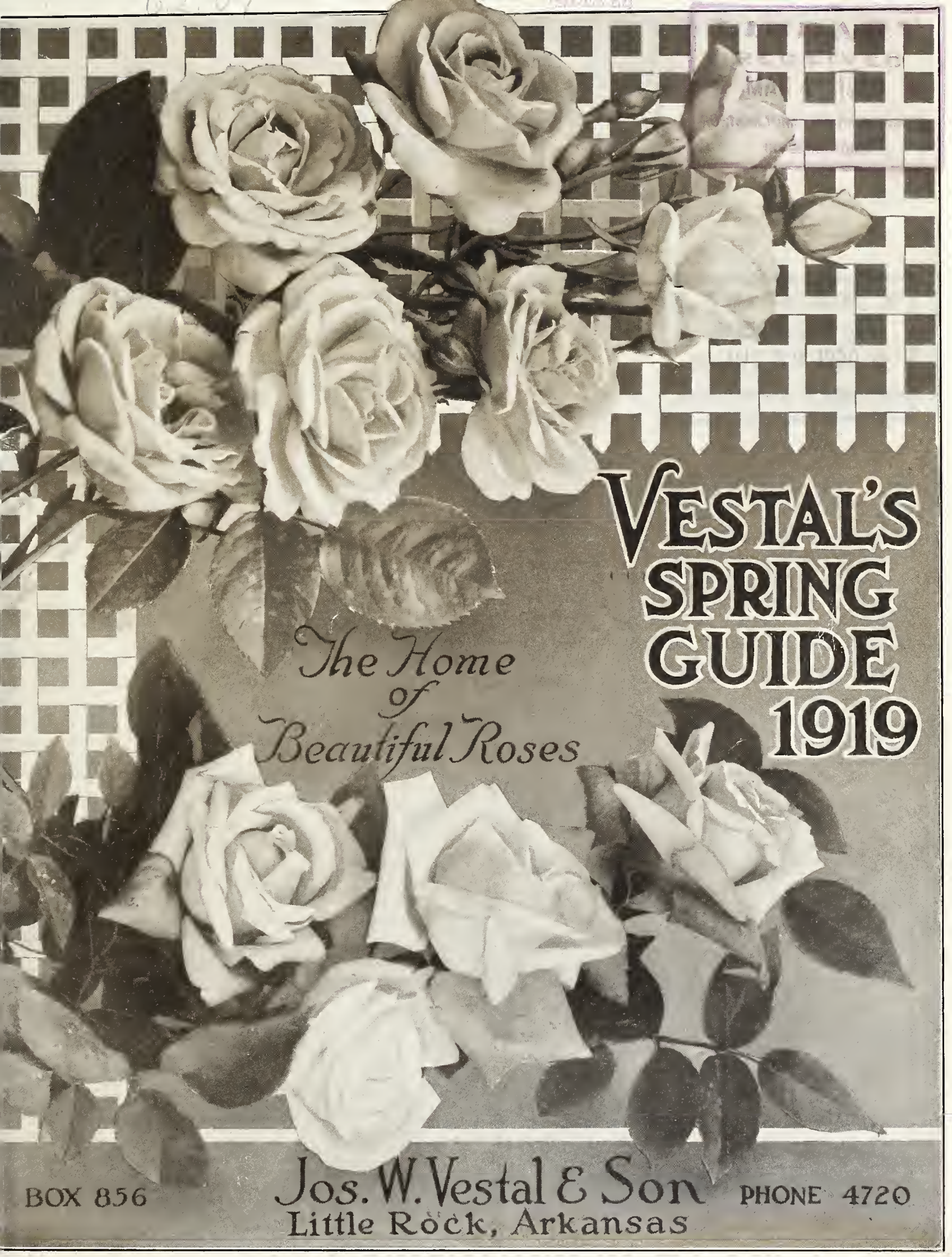




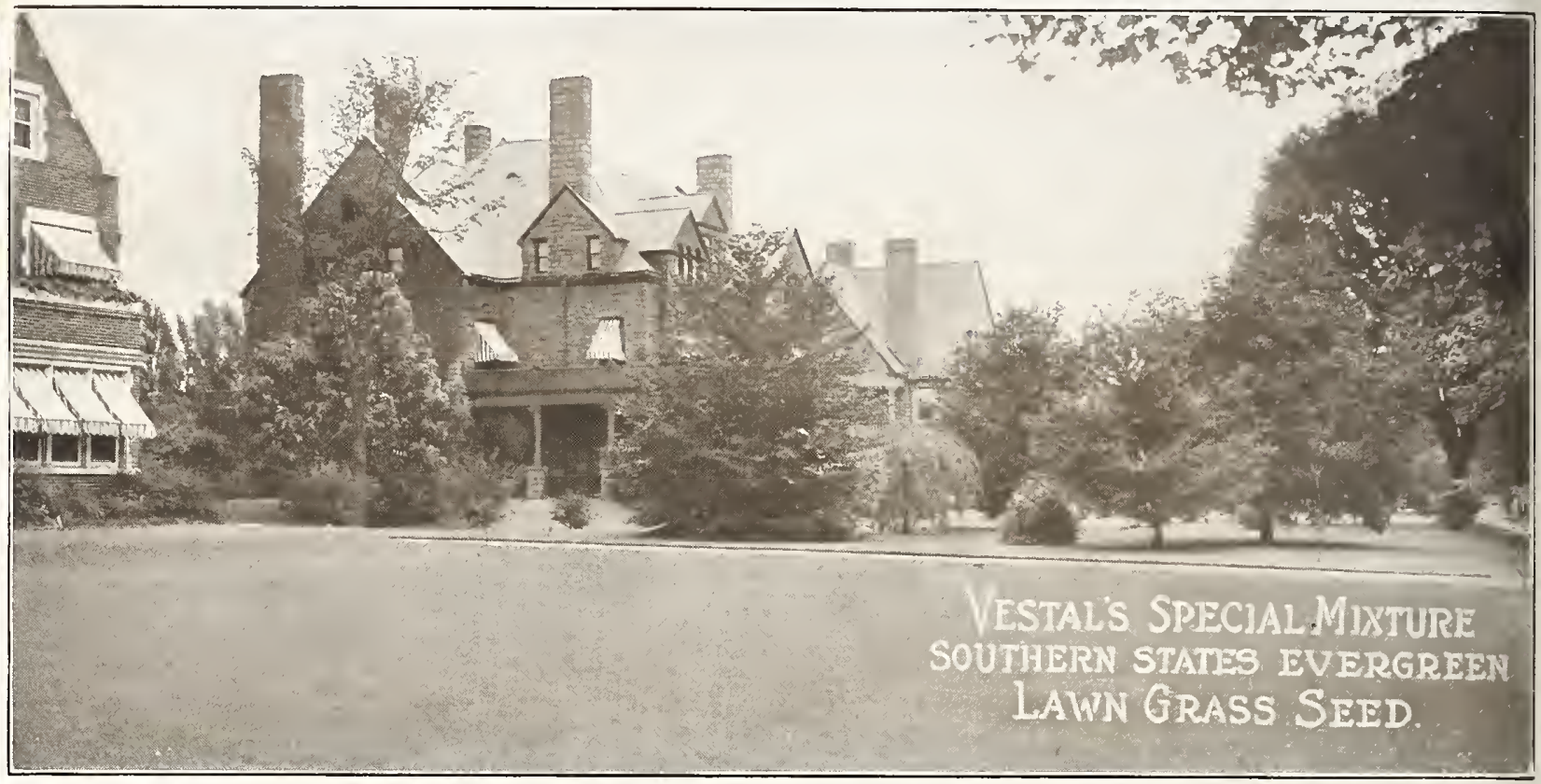

Southern States Evergreen Lawn Grass Seed For the convenience of those of our customers

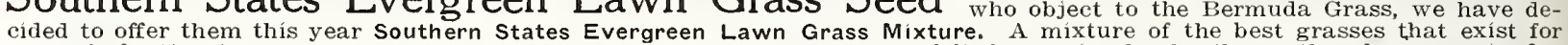

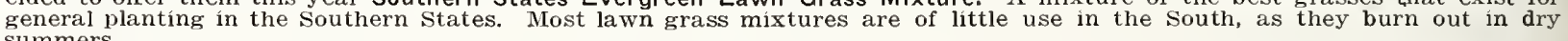
summers.

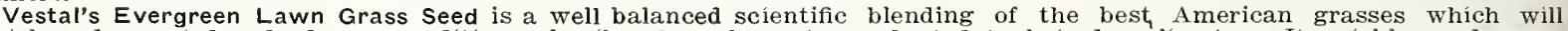

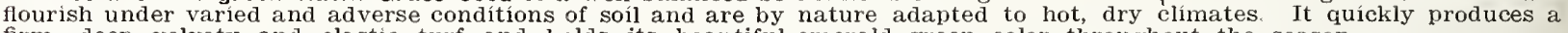
firm, deep velvety and elastic turf and holds its beautiful emerald green color throughout the season.

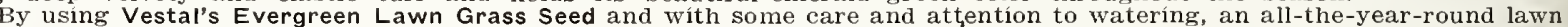

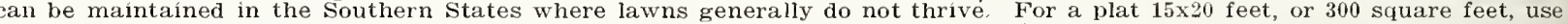
one quart. Príce, delivered free, 45 cents per quart; $\$ 1.25$ for 3 quarts; $\$ 2.00$ for 6 quarts.

CALIFORNIA PRIVET Conceded to be the best plant for hedging purposes. Remarkable for the beauty of its The Great Hedging Plant very glossy and wax-like; hardy everywhere. Real growth. The foliage is dark green, the value of your property by planting a California Privet hedge. Does well in all situations and under all condítions.

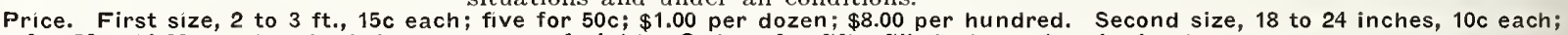
six for $50 \mathrm{c} ; \$ 6.00$ per hundred, by express or freight. Orders for fífty filled at one hundred rates.

AMOOR RIVER PR IVET Similar in habit to California, but with dark lustrous foliage and more upright Price, first size plants, habit of growth. Reputed to be hardier than the California

Price, first size plants, 2 to 3 feet, $\$ 10.00$ per 100 ; second size plants, 18 to 24 inches in height, 15 cents each; $\$ 1.00$ per dozen; $\$ 8.00$ per 100 .

\section{Dear Sirs:}

I must tell you of our real success in u s ing Southern States Evergreen Grass. Little over a year ago we built a home in a new part of Cairo. Our condítions $\mathrm{make}$ grass hard to grow, but after planting Southern $S t$ ate $s$ Evergreen Lawn Grass seed we have $s u m m e d$ and wintered it and it's just dandy.

MRS. H. S. CANDEE, Calro, III.

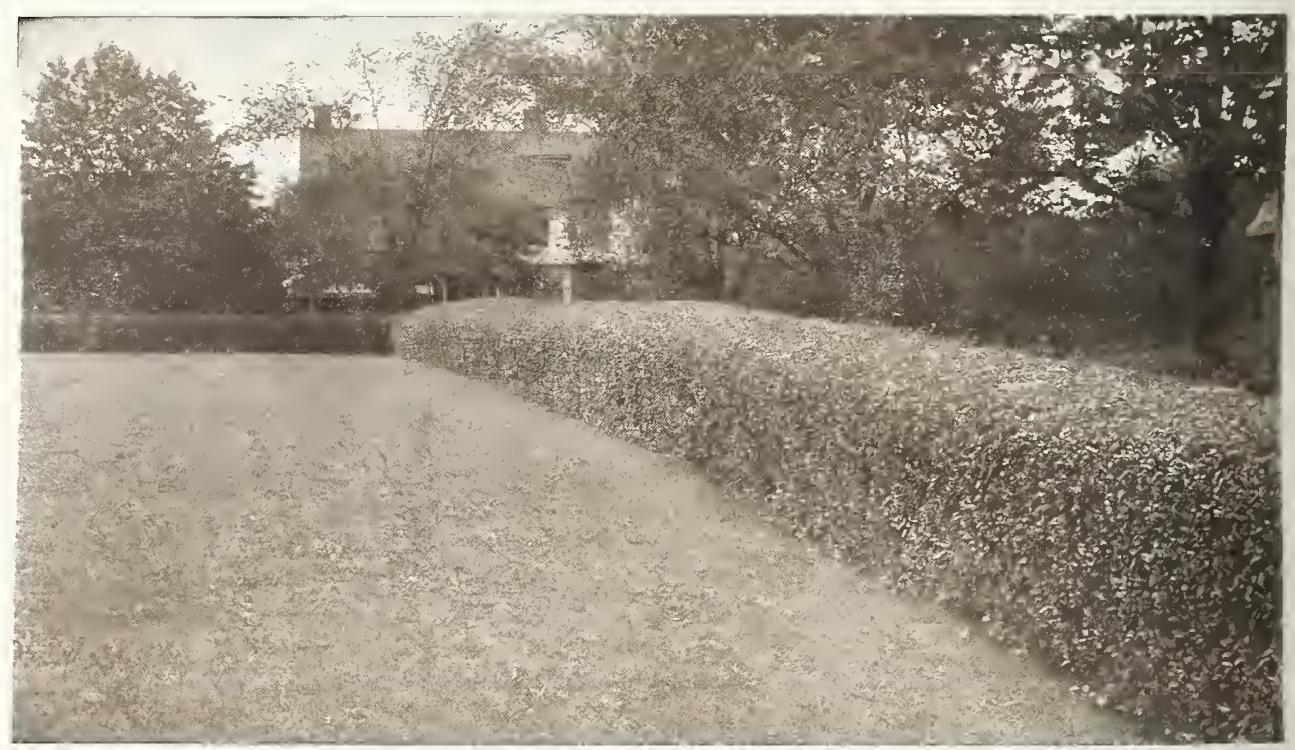




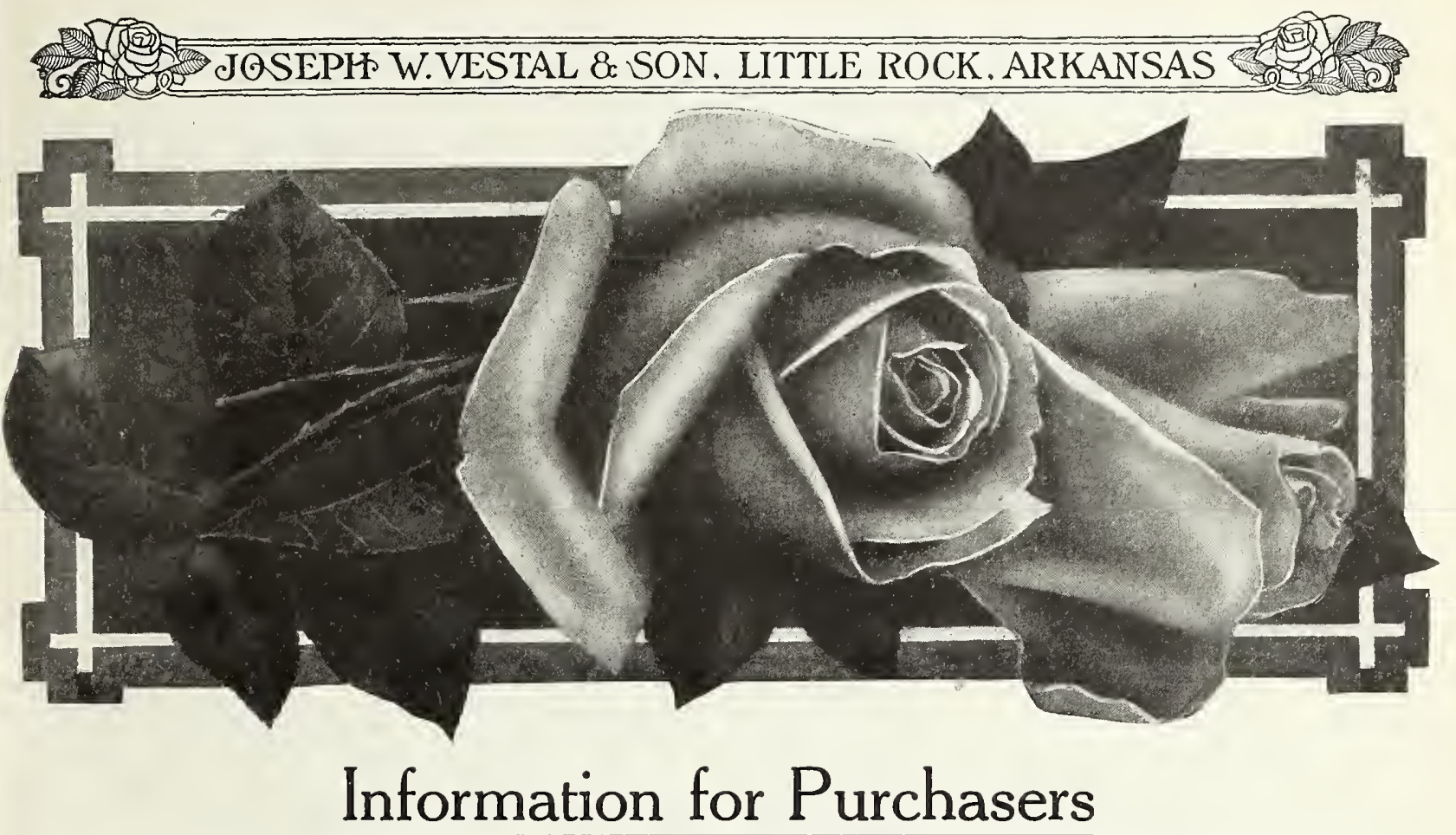

WHEN YOU ORDER, please use the printed envelope and order sheet enclosed. Others will be sent you upon request. Always write your name the same, adding the postoffice, county and State on each and every communication you send us. If you have occasion to write us, please use a separate sheet.

LOST OR UNSIGNED ORDERS. Letters are often sent us unsigned and letters are sometimes lost in the mails If you do not hear from us within a reasonable time, please send us a duplicate of your order, stating when and in what form payment was sent and sign the name and address the same as in the first order, so that it may have immediate attention

HOW TO SEND MONEY. Our terms are cash. To avoid delay please send money with order. Money may be sent at our risk if forwarded by $P$. O. Money Order, Express Money Order, Bank Draft or in Reglstered Letter, and cost of same may be deducted from amount forwarded; but we cannot be responsible for any order or money that fails to reach us when not sent as above directed. CASH should be sent by Registered Letter, but coins should be carefully wrapped and care taken to seal letter securely. New postage stamps accepted for small amounts.

AGENTS. We employ no agents and are only responsible for orders sent direct to us.

ERRORS. As an evidence of our human failings we sometimes make mistakes. Careful as we are to protect ourselves and our patrons, preach as much as we will to our employes, yet they occur; when they do, notify us at once; we will correct them promptly.

SHOULD YOU RECEIVE two or more Catalogues alike, which somet,imes occurs, have the kindness to present such as you do not need to others who will likely want plants. By doing so confer a double favor. We will also feel thankful for your recommendations of our establishment to your friends wanting plants. A copy of our Catalogue will be furnished to friends requiring plants on receipt of their address.

WHEN SENDING CLUB ORDERS please give full name and address of each member of the club, so that we may enter their names on our books and forward them our Catalogues as issued.

BETTER THAN WE PROMISE. We always do better than we promise in the way of extra plants, so when the order will at all afford it we add to it some plant or plants

gratis, often choice new kinds; several of the Roses now so eagerly sought after were first introduced to our customers in this way-presented with their order.

ORDERS BY EXPRESS. Two-year-old roses, large size shrubbery, fruit trees, etc, are too large to mail and must be sent by express. We recommend that customers instruct us to ship smaller size plants also by express, when in our judgment it is best to do so. We can send larger plants this way and can leave most of the earth on roots, which is, of course, much better for our customers. Express charges must be paid by the purchaser, unless otherwise agreed. But we are careful to pack as light as safety of the plants will permit and add as many extras as we can afford to help cover charges, and since the expressage on plants, bulbs, etc. is now twenty per cent less than regular merchandise rates, the cost of sending goods in this way, even to distant points, is quite reasonable.

OUR GUARANTEE. We guarantee all our plants to reach their destination in a good growing condition, but when we have done this our responsibility ceases, because we know that if they receive proper treatment they will grow nicely. Many plants die from careless treatment and neglect; in such cases we can not and should not be expected to replace them.

Do not be confused with senseless guarantees which mean nothing. The best guarantee is that given by a reputable house to deliver all goods in first-class growing condition, and falling therein, to replace them immediately. Furthermore, we guarantee that when goods are received, if they are not thoroughly satisfactory, we will make them so or refund your money. When plants reach you in good condition and are planted with ordinary care there is no difficulty in guaranteeing them to bloom at the time nature intended they should, which is sometimes termed "a seasonable time." It would be quite as sensible if we were to guarantee that they should bloom at any other time but at the time nature intended that they should, the so-called seasonable time. We are sure that a guarantee that states that plants are guaranteed to bloom under the above conditions, provided they are not winter killed or die from any other cause, will be taken for what it is worth. Vestal's plants are guaranteed to reach you in first-class condition, and if you give them any kind of care, we guarantee them to grow and bloom.

The firm VESTAL $\&$ SON has no connection whatever with any other concern in Little Rock or elsewhere, but is the old original firm established on this present site by Its founder, JOSEPH W. VESTAL, In 1880 . Letters addressed to VESTAL, LITTLE ROCK, ARKANSAS, will reach us. 


\section{Who Should Plant Roses. The Joy of Accomplishment}

Everyone should plant roses. There is no home, worthy of the name, where space could not be found for from ten to one hundred rose bushes. If a renter, plant roses; you will get returns in beautiful flowers in from two to three months. If a flat dweller, and you have three or more windows, you can plant ten or more rose bushes in window boxes. The results will be a delight, and you can move the window boxes with other personal belongings, when moving day comes around. If a home owner it matters not how pretentious or humble, nothing can make it more home-like, more attractive and inviting, than a well selected rose planting. If a landlord, there is no improvement that can be made at so small an expenditure that will so quickly enhance the rental value and desirability of property, insuring permanent tenants, as a good rose planting.

Roses are the most popular flowering plant grown. As either plants or flowers, they may be properly and effectively used for a great number of purposes. In the Southern States roses may be had in abundance nearly the entire year; longer than any other flower. We can never have too many roses around our homes; we seldom have enough.

The mild winters, long fall and spring seasons, and abundance of rain during the summer, give the lovers of roses in the Southern States a more ideal climatic condition for growths in the yard or open bed than any section of the world.

SOIL. If the soil is naturally well drained, it will be unnecessary to provide drainage. But nothing is more prejudicial to the health of Roses than poorly drained soil; therefore, if needful, provide drainage. Dig a trench to the depth of $2 \frac{1 / 2}{2}$ feet, and in the bottom deposit a 4 or 5-inch layer of drainage material so that all surplus water will drain away quickly. It is a good idea to mix with the soil in the bottom of the trench a few broken bones, say a peck, for a bed holding a dozen Roses-they will furnish plant food for the Roses for three or four years to come. A rich, deep clay loam is the best soil. If it contains grass roots, or is made up of rooted sods, all the better; any ordinary soil will answer, providing it is well manured.

MANURES. While manure from the cow-stable is probably best, you can draw upon the horse-stable or pig-sty with equal expectation of good results. Wellrotted leaves are fair, but too light except for heavy soils. Commercial fertilizers, such as bone or guano, may be used to advantage if handled with discretion. A rule to remember is never to let any "green" or "raw" manure come close to the roots of your Roses, but see that it is buried well beneath the root reach, or applied as a top-dressing.

The best time to apply manures is just as the ground begins to freeze in the autumn; let it serve as a protection over winter and dig it in next spring. Even with the best care it may prove necessary at times, say after six or eight years, to renew the Roses or move the bed, adopting the farmer's principle of rotation of crops.

TREATMENT ON ARRIVAL. When you receive the Roses, give them the greatest care; never expose the roots to the drying action of spring winds for a moment. A plant with bare roots exposed to the dry air is like a fish out of water. Should the plants, through delay in transit, come dried out, as occasionally happens, soak the balls of earth and roots in water; if the stems have dried out, after soaking the ball, bury the whole plant in damp earth for several days. This treatment may put them in good condition, while if they are planted when dried out there is danger of their dying.

TIME TO PLANT. The proper time for planting in the various sections of the country largely depends, first upon the location, "and, second, upon the character of the plant. In all sections where frosts are infrequent and the winters mild, pot-grown as well as dormant Roses may be planted in the late fall, as well as in the early spring. In the Southern States fall planting of both these classes of Roses is considered desirable, but, if the conditions are such that it can not be accomplished, then in the early spring months, they may be set out with entire safety.

As to where the preference lies between plants that are pot-grown under glass, and dormant, field-grown plants, it is not easy to discriminate. Our own experience has been that in the Southern and Southwestern States, the planting of the one-year-old Roses during the months of February, March and April, according to the location, may be accomplished with splendid satisfaction.

MULCHING. The main object being to retain the moisture rather than to enrich the soil, cultivate the garden once a week up to the middle of July, to maintain a dust mulch; after that, a liberal covering of "long" cow or horse stable manure that will not heat will accomplish this purpose best.

HARDINESS. Hardiness in a Rose is a matter of which no one can speak with positive certainty, because the condition of the weather as a rule prescribes the hardiness of a plant, as quite frequently plants that have been out year after year will be winter killed by unusual conditions. As stated elsewhere, the hardiness of the different varieties of plants can be depended upon to be as near accurate as it is possible for any one to determine.

WINTER PROTECTION. Where the temperature gets below freezing, the less hardy Roses will require protection, and all of them will be better for it, at least about the roots. Soon after the first frost, having hilled up the soil around the stems, cover the Rose beds all over with a 3 or 4-inch layer of good heavy stable manure, and over this a 6 -inch layer of leaves, held in place by the most sightly material available. A 12 -inch fence of poultry wire will keep the leaves in bounds nicely. If the leaves are not available, straw, corn-fodder and even boxes put over the Roses to shed the rains, will protect from the cold, biting winds and the alternate freezing and thawing of early spring sunshine and cold

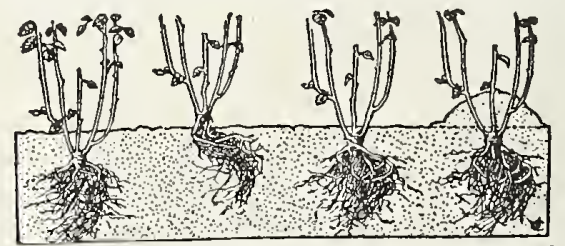

Too deep Too shallow Just right Right and and setwrong nights; but do not smother the Roses, for if too tightly covered they will die. Remove the covering gradually in the spring when danger from frost is past. 


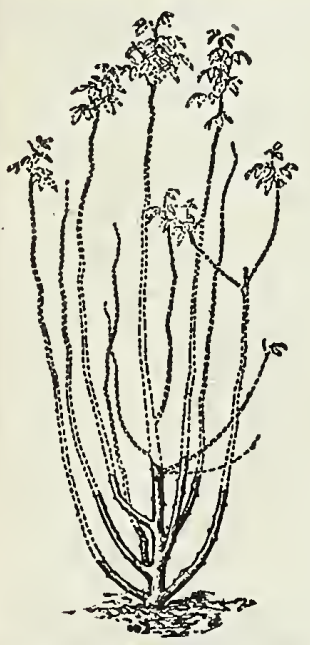

Showlng where to prune.

\section{How to Prune Your Roses}

Pruning is the art of improving the productive power and the appearance of a plant. It consists of two distinct operations. 1. The removal of dead, weak, overcrowded, and otherwise useless shoots. Unripe wood which in the spring will usually be found to have discolored pith, caused by the winter frosts, should be cut clean away at the base of the shoot. 2 . Pruning Proper, the shortening of those shoots which are allowed to remain after the thinning-out process has been completed.

The most frequent errors made in pruning are: (1) leaving too many shoots when thinning out: (2) pruning severely the shoots of varieties which require little, if any, shortening: (3) pruning lightly the varieties which require severe pruning; (4) leaving Rose plants crowded with shoots and cutting these to a uniform length all over the plant in a similar way that a hedge is clipped.

In thinning out a shoot, it should be either cut clean away to the base of the plant, or to its starting point on the elder shoot from which it springs, as the case may be. When the plant has been pruned, the shoots should be left as nearly as possible equidistant from each other, and regularly arranged around it so that it presents a well-balanced appearance on all sides.National Rose Society's Handbook on Pruning.

\section{Diseases and Insects}

MILDEW-This disease very frequently attacks the foliage of Roses, especially the Crimson Rambler. It is shown by a grayish crinkling appearance of the leaves and usually occurs after a change in the temperature. It can be checked to a certain extent by sprinkling the leaves with powdered sulphur immediately after its appearance. If, however, this does not check it, dissolve one ounce of potassium sulphuret in two gallons of cold water and apply a fine spray.

GREEN FLY OR APHIS-A green suckling insect which usually gathers in great numbers upon the tips of the new growth. A solution of tobacco made from tobacco insecticide soap, which you will find offered elsewhere in this book, will exterminate them.

RED SPIDER-Is also a small insect indiscernible to the naked eye, and a frequent spraying with a strong hose is all that is necessary.

LEAF ROLLER. Is an insect of yellowish-white color, resembling the butterfly, and lays eggs on the underside of the leaf, which soon form a cocoon, rolling around itself the leaf, hence the name, leaf-roller.

ROSE BUG-A familiar insect, appears in the earliest summer, sometimes in great quantities, and is very troublesome. It is a very destructive insect and usually feeds. upon the white petals, but is easily destroyed, especially in the early morning, when they will readily fall into a vessel containing kerosene. They can be poisoned, but it is not a very desirable way to get rid of them. This is to spray with wood alcohol, which will kill any insect by contact, operates quickly and does not injure the flower if applied in a mist-like spray. Care should be exercised by the operator not to inhale any of the fumes.

BLACK SPOT-A fungous disease, appearing as its name indicates as a black spot upon the leaf, eventually turning yellow and falling. It rarely occurs in the early part of the season, and the Teas are almost, but not quite, exempt from its ravages. The best preventative if your bushes have been troubled by it in the past is spraying in April before the foliage has developed and not while the flowers are in bloom, because of the discoloration of the foliage. The disease usually appears at the base of the plant and works upwards, so a watch should be kept and as soon as any leaves appear affected with this disease they should be pulled off and taken entirely away from the balance of the plants. If this is thoroughly done it will usually hold the disease in check.

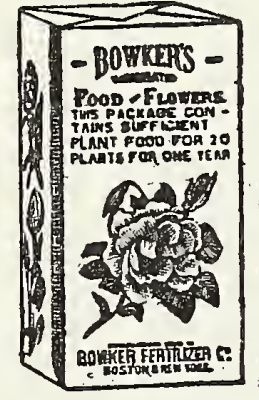

\section{Bowker's Ammoniated Food for Flowers}

A new odorless Fertilizer for Pot plants. Makes plants grow and bloom luxuriantly, and drives insects from the soil.

It starts the plant at once into a healthy and vigorous growth and abundant bloom. It drives worms and other troublesome insects from the soil. It has no disagreeable odor, and is the only artificial fertilizer which can be used without danger or injury to the plants. It takes the place of liquid manure, and is just the thing that has been wanted for a long time. We have sold tens of thousands of packages of it, and have yet to hear the first complaint. If your plants are doing poorly, get a packet and see how quickly they will be benefited. It acts like a charm. The Ammoniated Food is put up in wooden boxes, with attractive wrappers. One package, sufficient for twenty-five ordinary-sized plants for one year, for 50 cents. Sent by mail, postage prepaid, on receipt of price.

\section{Insecticides}

Thompson's Rose Nicotine is chemically pure nicotine and quick death to insects on Roses. Very convenient to use-no trouble, no odor, no staining; simply apply as directed with spray pump or plant sprinkler. Small can, 30 cents; larger size, 60 cents, postpaid.

Tobacco Powder-The Sprinkling Kind for Sprinkling or Dusting Only, is made from heavy black leaf tobacco, strong in nicotine, and so finely pulverized that it can be applied with an ordinary magazine bellows gun direct to plants, indoors or out, or sprinkled around the hothouse to keep the pests in check. Price, one-pound package, 35 cents.

Sulpho-Tobacco Soap. Another splendid insecticide. Directions for use on every package. $3-0 z$. cake makes $1 \frac{1}{2}$ gallons prepared solution, 15 cts. each.; $8-\mathrm{oz}$. cake makes 4 gallons prepared solution, 30 cts., postpaid.

Hellebore, Powdered White. For the destruction of slugs, worms, caterpillars, etc. Less poisonous than Paris green and London purple, and safer to use. Use as a powder or dissolve one ounce in three gallons of water. Postpaid, $1 / 2$ lb., $40 \mathrm{cts}$.; lb., $75 \mathrm{cts}$.

Grape Dust. For mildew, mold or rust mites. Price, $1 / 2$ lb., 25 cts., postpaid.

Bordeaux Mixture (Dry). For dusting plants affected with mildew and all fungous diseases. Can be used as a spray. 1-lb. box, 35 cts. (makes 5 gallons liquid); 5 lbs., $\$ 1.25$, by express.

Slug Shot. Is an Insecticide for the destruction of Potato and Rose Bugs, and all Iice, Worms or Caterpillars upon Melons, Eggs, Cucumbers, Cotton, Tobacco and Cabbage Plants, Tomatoes, Currants, Fruit or Ornamental Trees, Grape Vines, Shrubs and Flowering Plants. An admirable remedy for the Black Clematis Bug.

Directions for Use: Slug Shot is an impalpable composite powder, to be dusted upon the plants. It contains Poison, thoroughly diffused through natural fertilizers, and is perfectly safe in its use to man or beast. Price, one-pound package, 25 cents, postpald.

RUBBER PLANT SPRINKLER. Large size, \$1.10 postpaid. 


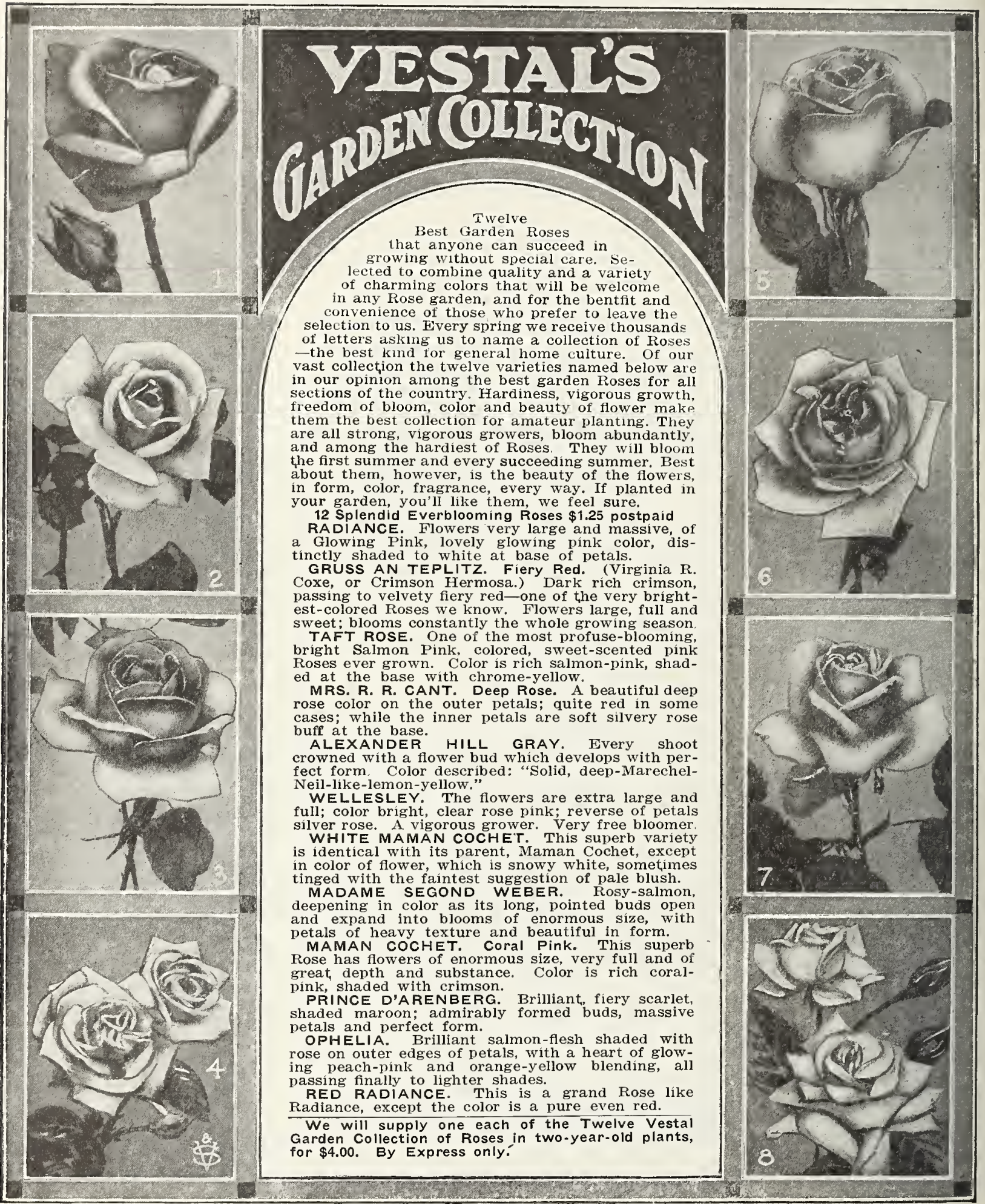




\section{COLUMBIA - The Best New Rose of the Year}

Could be rightfully called the Giant Pink, owing to the enormous blooms it produces Of distinctive merit, being an extremely strong, rank grower, one of the strongest of the everblooming, blooming as it does with the greatest freedom, the buds carried on long, stiff, erect stems, of the very largest size imaginable in a Rose bloom, open flowers often measuring six inches across, full of petals and of wonderful depth, which it retains in perfect formation. Very fragrant. Color clear imperial pink on the order of the La France, deepening as it opens to glowing pink. A peculiarity of the variety is that the shades all become more intense until the full maturity of the open flower is reached, and this color is enduring. Being fully double makes it a fine summer Rose, particularly adapted to garden culture. We feel that after all is said, we have not said half enough for Columbia. Price, one-year, 25 cents; two-year, 75 cents.

\section{Double Ophelia}

This new Rose has the brightest future, in our estimation, of any Rose introduced for the last quarter century. The color is one so difficult to describe that any description can only be a partial one, and gives but a faint idea of the superb beauty and richness of the shades Salmon-flesh, shaded with rose. Buds of unusual attractiveness, opening full and double, like the old Malmaison, but decidedly brighter. Habit excellent, growth strong produces flowers on long stems, standing well up above the foliage, and in great profusion all summer. Price, 35 cents each; two-year, $\$ 1.00$ each.

\section{Freiherr Von Marshall}

Wonderfully Strong Growing and Hardy.

As an outdoor Rose it has no superior. It has wonderfully beautiful foliage and produces large, full, beautiful shaped flowers, which are borne in profusion all through the season Magnificent, crimson-scarlet Hybrid Tea Rose with long and pointed hubs; delíciously fragrant. Wonderfully strong growing and hardy. Price, one-year-old plants, 15 cents each; two-year-old plants, 35 cents each.

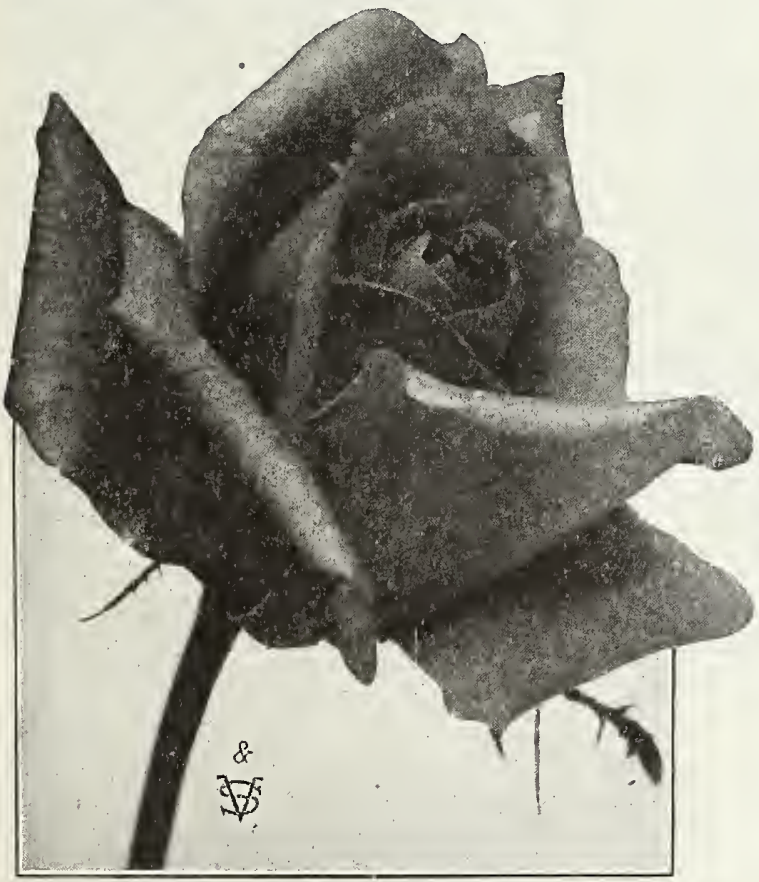

Freiherr Von Marshall.

Intense and rich in coloring.

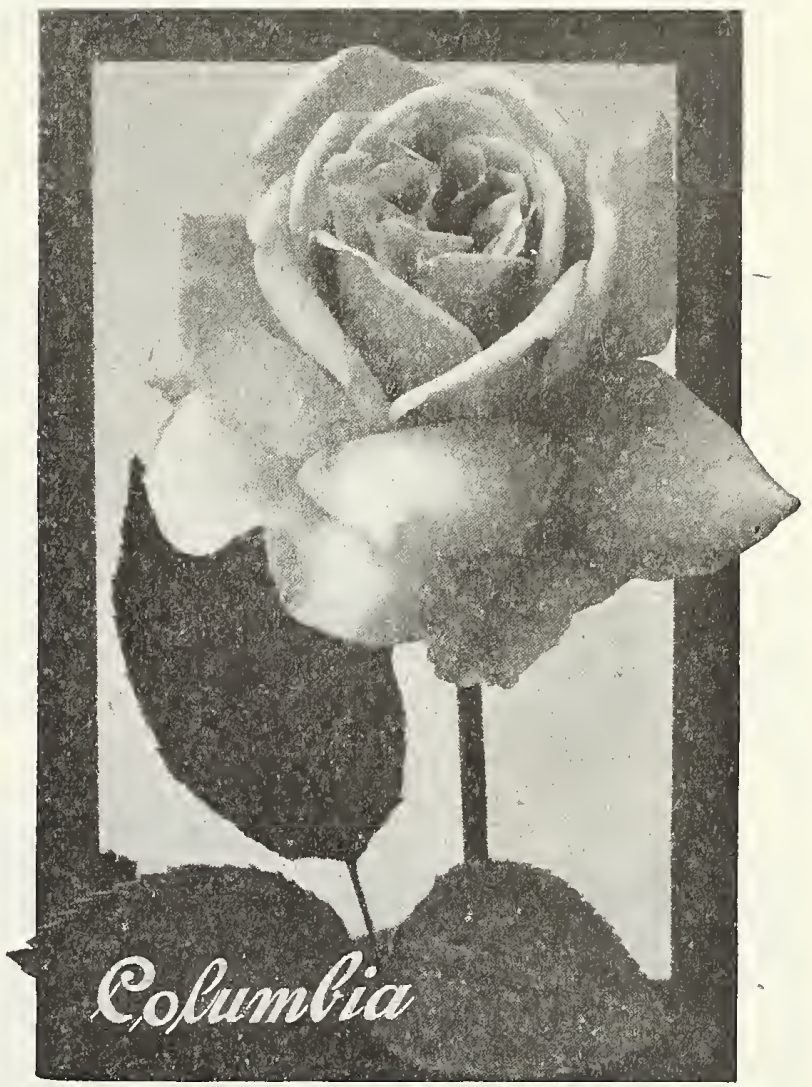

\section{Our Roses}

Are grown in $3-1 \mathrm{NCH}$ pots.

They are superior to the young Roses from two-inch pots usually sent, out because the larger pot gives ample room for root action and allows the plant to grow naturally. They are sturdy and compact and when sent by express with the soil on the roots, transplanting scarcely che cks their growth. The cut shows a fair sample of the two-inch pot plants as usually sent out by the mail trade, (and a fair sample taken from our stock, growing in three-inch pots)

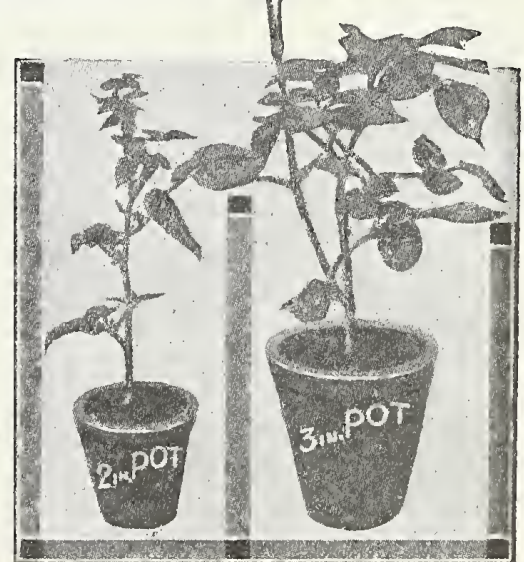




\section{NEW HARDY EVERBLOOMING ROSES}

\section{NATIONAL EMBLEM}

Owing to its magnificent color and formation, this Rose was named National Emblem, and no Rose in our estimation has a better right to the honor of being the Standard Bearer. Its color is a deep crimson overlaid velvety crimson shading to vermilion toward the edges. Buds long and pointed on stout stems opening full and double, each one coming to perfection and produced in marvelous profusion throughout the entire season. Plants make a gorgeous sight owing to the brightness of the blooms and the luster of the foliage, being entirely free from mildew. A grand garden or bedding Rose. Price, 30 cents each; two-year-old plants, 75 cents each.

\section{Mrs. Theodore Roosevelt}

Creamy white, with rose center; bud, long and pointed; flowers very large, full and of splendid form. A vigorous grower. Grand bedder. Its freedom of bloom is most remarkable, beginning on very small plants and continues without interruption. Price, one-year-old palnts, 20 cents each; two-year-old plants, 50 cents each.

\section{HELEN GOULD}

It has proven itself to be the strongest growing, freest blooming, largest flowering and hardiest Rose in existence. It is a better Rose for general planting than American Beauty-the dream and hope of every Rose grower for years past. A strong, dwarf, compact grower, absolutely free from disease of all kinds, young plants blooming continuously throughout the year. The flowers are as large as the American Beauty, are full and perfectly double; the buds are beautifully made, long and pointed, produced on long, stiff, erect stems. The color is a warm rosy crimson, the color of a ripe watermelon. Price, 15 cents each; large plants, 40 cents each.

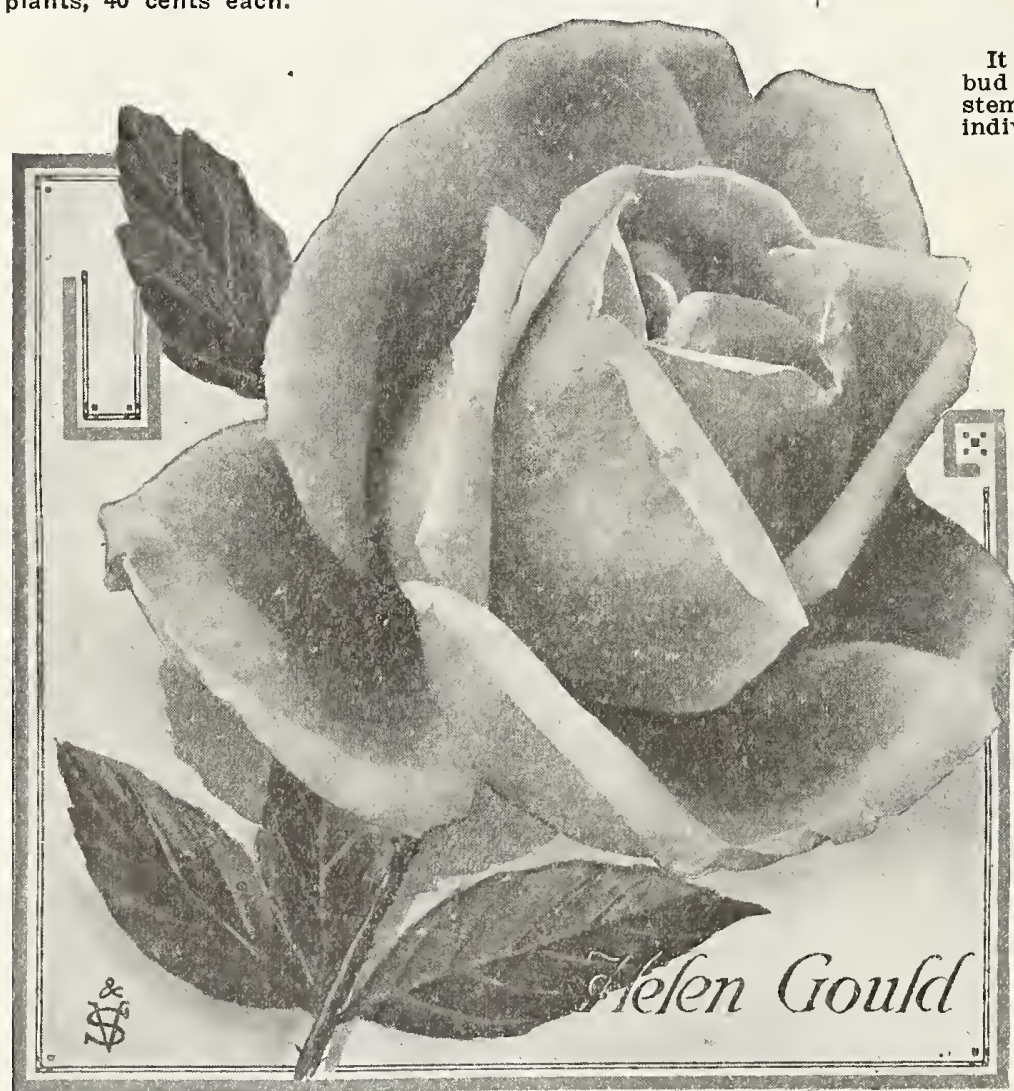

Long pointed buds, rosy crimson In color.

\section{Mrs. David Jardine}

A Wondrous, Hardy, Brllliant, PInk Bush Rose.

An exquisite new Hybrid Tea of a shade of brilliant pink not equaled by any other Rose: The color varies from a deep shade in the center to an exquisite salmon tint on the outer petals, with a peculiar soft, pastel effect. Its petals exhale a fragrance only to be compared to the famous Attar of Roses. The lasting quality of the flowers when cut is marvelous. They have been known to keep in perfect condition more than a week in water. A wonderfully vigorous grower, absolutely hardy everywhere, bearing its flowers in great profusion all summer. Price, one-year, 20 cents each: two-year, 50 cents each.

\section{Pernet's Triumph}

The flowers are extra large, having broad, thick petals and long tapering buds, with delicious fragrance. Color, a fine clear magenta red, sometimes passing to bright crimson. The flowers retain their beauty for a long time. Price, 15 cents each; two-year-old plants, 30 cents each.

\section{President Carnot}

It is a Rose of the largest size, beautiful both in bud and open flower. The buds come on long, stiff stems, in clusters of from six to twelve. Each individual flower stands out distinct on its stem. No crowding as in the case of so many Roses that bloom in clusters. The color is distinct and novel, a lovely fawn, shading to pearl. it often measures five to six inches in diameter. We have no hesitation in saying that this charming Rose will become as popular as La France, as it has all the good qualities of that Rose, and at the same time is so distinct that it atracts immediate at,tention. It is, indeed, a wonderful Rose-one that everybody can grow and bloom. Price, fine young, strong plants, 15 cents each; fine two-year-old plants, 40 cents each.

\section{Mme. Cecile Berthod}

Deep golden yellow Rose. Most beautiful, both in bud and flower, which is deep golden yellow. In fact, the deepest yellow in color of any Rose we grow. The foliage is very bright. This is a Rose of magnificent size and color. Price, 15 cents each; two-yearold plants, 35 cents each.

\section{Lady Battersea}

This variety has long oval buds, sharply pointed, very striking in form: the color is bright cherry crimson; the stems are stiff and extremely long for a red Rose; a vigorous grower; not very full, but an unusually showy variety; the only red Rose approaching Niphetos in form; color, brilliant and unusual. Price, 10 cents each; large two-yearold plants, 35 cents each.

Kind Friends: Your pleasant surprise box of plants sent me came yesterday. The plants were in good condition and a better assortment I never saw, and so many for the price. I am greatly proud and pleased with them. Thanking you for your good selection and promptness, I am still remaining yours for success. MRS. M. C. JENKINS, Kansas City, Mo. 


\section{PINK RADIANCE AND RED RADIANCE}

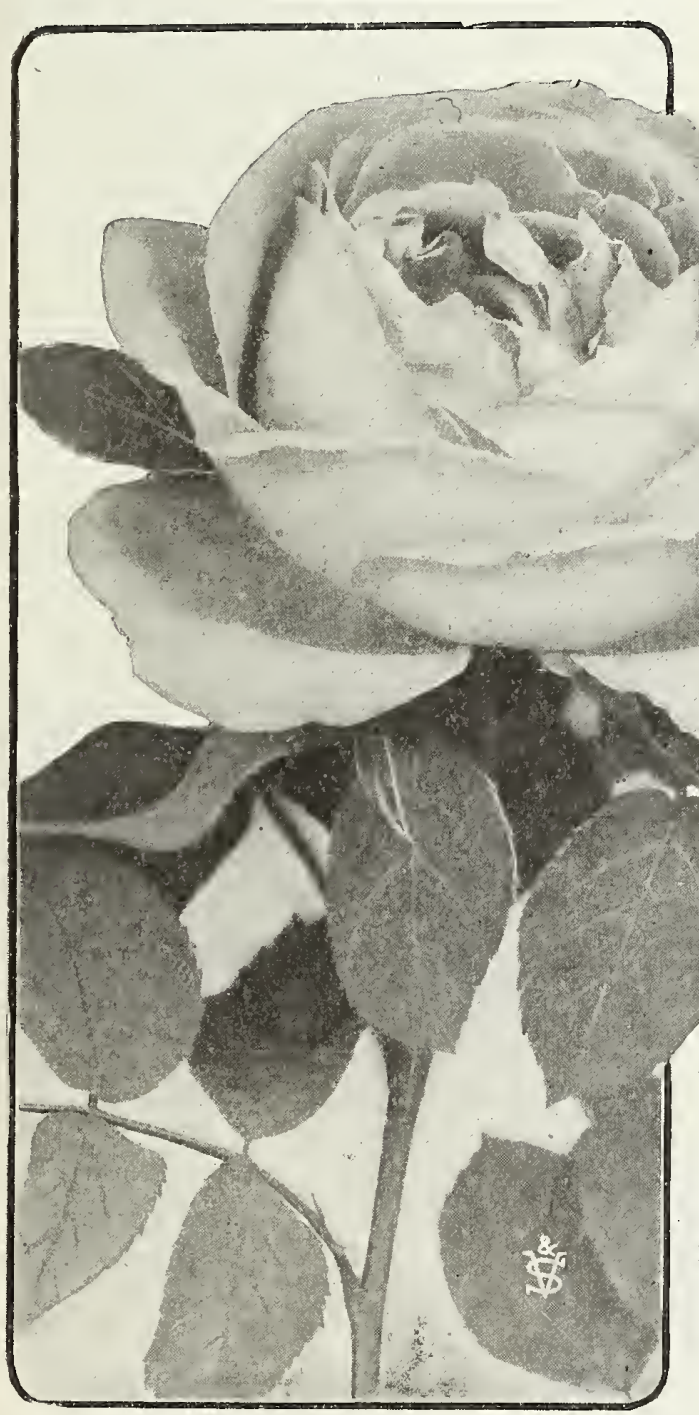

In the Radiance Roses are found all the good qualities that go to make an ideal garden Rose-grand size, handsome form, free flowering, hardiness, pleasing colors.

\section{RADIANCE}

MAGNIFICENT ROSE.

(Giant Flowering, Handsome in Form and a Wonderful Garden Rose.)

This grand, giant-flowering Rose stands head and shoulder above all other Roses of its class. The flowers, which are of splendid form, are large and full, and somewhat of the June Rose type. The buds are particularly handsome in form, the full blooms large and double, the petals of immense size and the blossoms are highly perfumed. The growth of the plant is vigorous, making strong canes which are thick and heavy. Radiance is rightly considered a leading Rose of the garden for cutting and successfully competes with many of the finest greenhouse productions as a cutflower variety. Radiance produces a wealth of heavy, clean, dark green foliage and has the qualities that make it the ideal garden Rose. Price, strong plants on own roots, 20 cents (wlll bloom the first season); two-yearold plants, 50 cents each.

\section{RED RADIANCE}

No Rose has yet equalled, certainly none has excelled Radiance as a garden Rose, when all points are taken into consideration, such as hardiness, freedom of bloom, vigorous growth and character of bloom. In Red Radiance we have an exact replica of its prototype, Radiance, except in color and bud, The color is an even shade of clear red, without a trace of any other color, retaining its vividness for an unusually long time after being cut. It is a remarkable bloomer, being constantly in flower, from early spring until freezing weather. Strong, vigorous, branching grower, each branch terminating in a large, bold, double bloom. Hardy everywhere. Altogether it is a Rose destined to become one of the leading garden Roses of America. Price, one-year, 20 cents each; two-year, 50 cents each.

Gentlemen: As a result of early planting and then later planting, I have had a wealth of lovely Hyacinths, Narcissus, Roses and Violets for the Holidays and all during the autumn. I recommend your Roses to my friends. MRS. R. MOSELEY, Stonewall, La.

The flowers of Radiance are somewhat of the June Rose type, immense in size and highly perfumed.

\section{STRIPED RADIANCE}

Exceptionally Striking in its Variegation.

Striped Radiance is a sport of the now famous cut-flower Rose Radiance. The flowers are large, ground color soft carmine striped and dashed with creamy-white. The Rose is extremely beautiful in its bud-form, being quite long pointed. Habit of growth is vigorous and branching, and this Rose will always prove one of great interest. Really a distinct novelty. Nice one-year plants, 25 cents; 3 for 60 cents; strong two-year plants, 50 cents; 3 for $\$ 1.25$.

Striped Radiance is an Interesting novelty. Everyone should try.

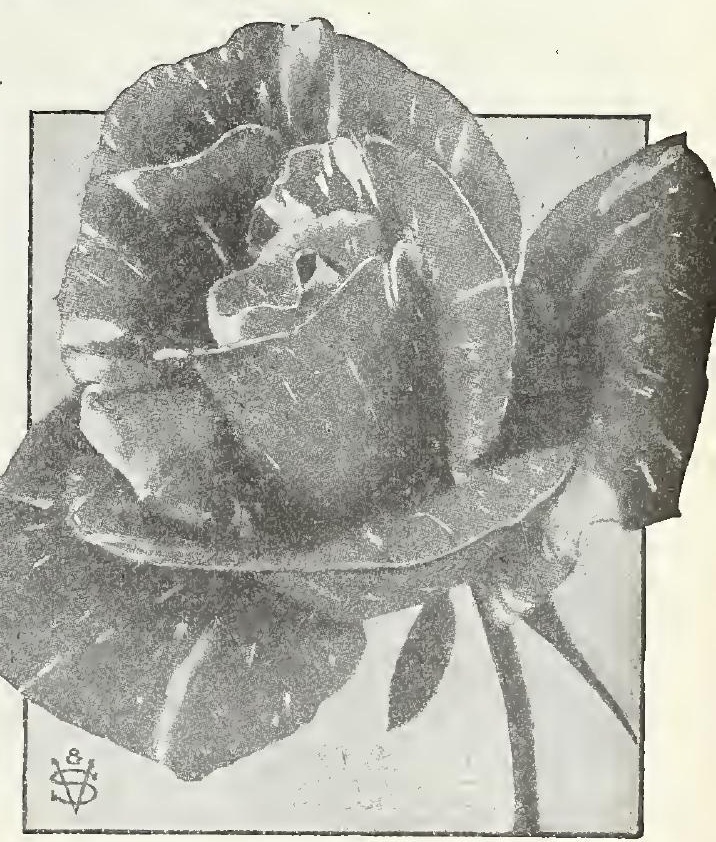




\section{SIX WONDERFUL RED ROSES}

THE NEW

AMERICAN ROSE

\section{FRANCIS SCOTT KEY}

"The Rose for Every Garden of Every American Home." "Named in Honor of the Writer of tha Star Spangled Banner."

The new American Rose, Francis Scott Key, dazzling crimson, globular Rose of gigantic size. In this new Rose we find the embodiment of a perfect bloom combining size, form an color, the attributes of all exhibition flowers. This new American Rose produces intensely black grain scarlet-crimson blooms on strong shoots of sturdy erect growth, embellished with a foliage of the deepest green. The Rose is deliciously perfumed. In growth it is strong, vigorous and freebranching, with large and handsome foliage. Beautiful as are the hundreds at present in cultivation-as ideal varietiesfor every purpose, the new American Rose, Francis Scott Key, is the most outstanding and represents the greatest effort in American hybridizing, possessing as it does, all the good qualities an American everblooming garden Rose should have. It should be of considerable interest to all and most gratifying that we should have such a wonderful Rose named in honor of the writer of The Star Spangled Banner. Francis Scott Key is the Rose for every American home and should be planted in every garden. Price, strong, one-year-oid plants, 20 cents each; two-year-oid plants, 60 cents each.

\section{Hadley}

In the Hadley we have a Rose that possesses a rich and lasting crimson color, coupled with vigor of growth, robust, constitution, and free blooming habit. It will be welcomed alike by the grower who forces Roses under glass for cut flowers and the one who plants outdoors for summer flowers. It is a development of a strain of red Roses, including Liberty, General McArthur and Richmond. The color is magnificent, rich velvety, crimson, retaining its brilliancy throughout the season. The fragrance is delightful and refreshing. The flowers are borne on long stems and keep in good condition a long time when cut. The growth is splendid, sturdy and healthy, the foliage large and abundant. Price, one-year-oid plants, 20 cents; two-year-oid plants, $50 \mathrm{c}$ each.

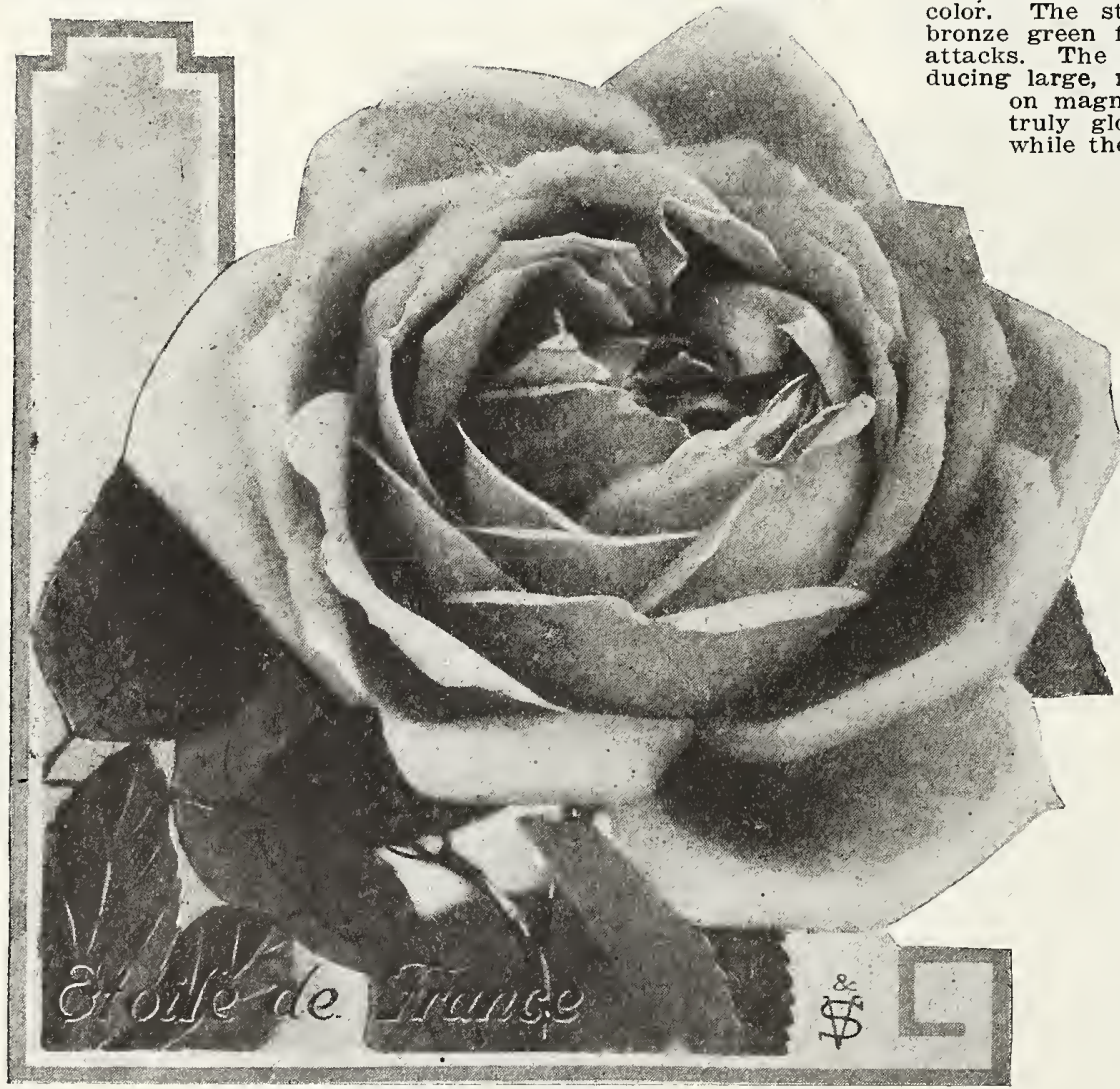

Etoile de France

The Crimson Garden Rose, a Rose in which we find the embodiment of a perfect bloom, size, form and color.

\section{Cherry Ripe}

Beautiful, Fragrant, Hardy.

One of the brightest vivid crimson scarlet Roses in existence. Of free branching habit of growth; very vigorous and healthy. Every shoot produces a large, double, well-formed flower, which, combined with its fragrance and hardiness, makes this essentially one of the greatest red Roses for outdoor planting. Price, 15 cents each; two-year-old plants, 40 cents each.

\section{ETOILE DE FRANCE}

\section{Magnificent in Form and Coloring.}

One of the best and sweetest hardy Roses of its color. The strong, upright bushes have beautiful bronze green foliage which is not subject to insect attacks. The bushes are blooming constantly, promassive, deep, full cup-formed flowers magnificent, long, stiff stems. They are of ruly glorious form and delightful fragrance, color is exquisite-a clear red of velplants, 15 cents; two-year-old plants, 40 cents each.

\section{General McArthur}

\section{one of the Very best Red Bedding} Roses.

General McArthur is as fragrant as a Rose can be; has good sized flowers and blooms continuously. The bud, when first opening, is the brightest crimson-scarlet and the flower retains this perfect coloring until it drops its petals. Blooms continuously the whole season through and gives fine stems for cutting. Its habit of growth is remarkably good, making strong, shapely plants that may be depended on for large flower shoots. A great favorite. Price, one-year-old plants, 15 cents each; two-year-old plants, 40 cents each.

\section{Mevrouw Dora Van Tets}

A chaste Rose of great beauty. "The habit of growth is perfection, every shoot producing a bloom, a veritable pearl for garden decoration. The color is a deep glowing crimson; a flower you want to linger with, and which you visit again and again. Price, one-year-old, 20 cents each: two-year-old, 40 cents each.

\begin{tabular}{c} 
Try Our Trlal Collectlon of \\
Everblooming Roses \\
SIXTEEN CHOICE VARIETIES \\
\hline Very Fine Plants. Best Sorts. \\
\hline OUR SELECTION, $\$ 1$ POSTPAID.
\end{tabular}



ROSES-_-PURE GOLDEN YELLOW AND 'SHADES OF YELLOW

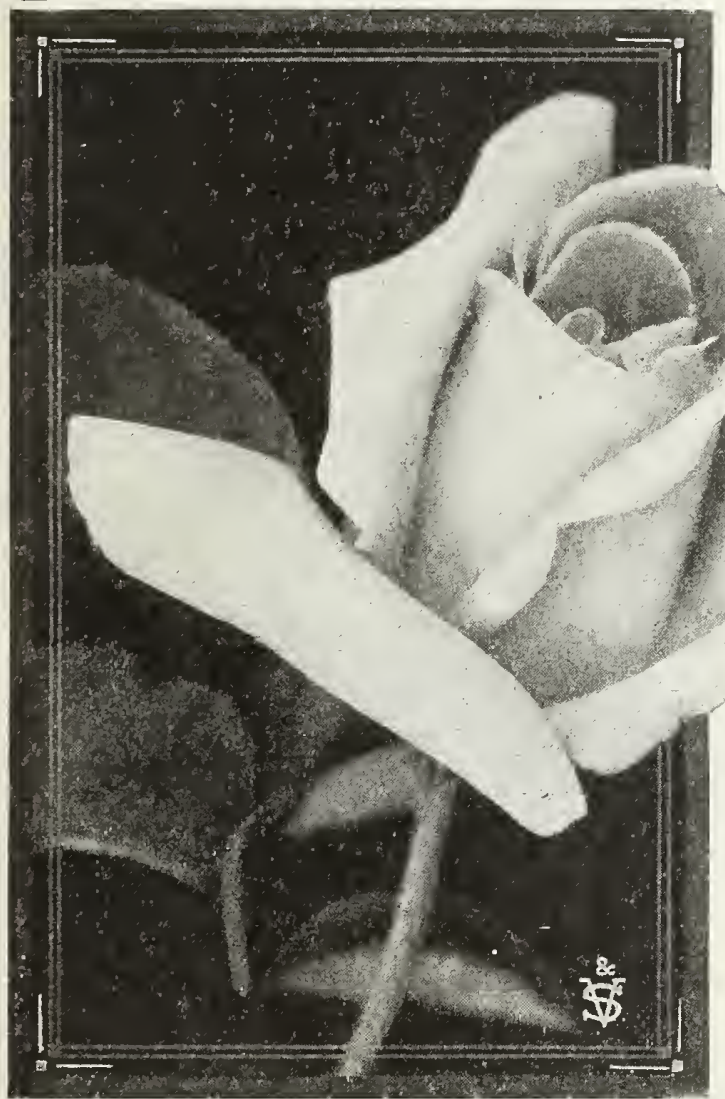

\section{SUNBURST}

"Stands Head and Shoulders Above All." This magnificent giant-flowering Rose stands head and shoulders above all other Roses of its class. It is a constant blooming variety, producing fragrant blooms of an especially deep color throughout the summer. It has all the good points of merit; a fine long pointed bud; long stems; extraordinary vigorous and healthy, and belongs in the class of big Roses. The color is a beautiful orange-copper, golden orange and golden yellow, large intense shades, and brilliant in effect. Price, strong one-year plants, 20 cents each, three for 50 cents; two-year plants, 50 cents each.

\section{Mrs. Aaron Ward}

This Rose is a real joy to the grower and absolutely distinct. One of the most delightful Roses of recent years, in a color that catches the eye at once. Coppery orange in the open bud, golden orange when partly developed, pinkish fawn of lovely shade when fully open, when it looks like a full fluffy rosette. No wonder everybody that sees it falls in love with it. Price, 15 cents for oneyear-old plants: 35 cents for two-year-old.

\section{Blumenschmidt}

This is undoubtedly the best Pure Yellow Rose for garden planting yet introduced; color is clear bright golden yellow; the plant is a strong, robust grower and very hardy; makes beautiful buds and is very double and sweet, and one of the very best. A sport from Mademoiselle Franciska Kruger. We believe it to be the only good yellow bedding Rose up to date. You had better try some of this, as unquestionably it has a great future. Price, 15 cents each two-year-old plants, 30 cents each.

Illustration Snows Flower of Golden Orange Rose Sunburst.

Herzogin Marie Antoinette The New Orange Yellow Rose

Hybrid Tea of deep orange, striped salmon crimson, passing to old gold or orange. Very large flowers of perfect form produced on heavy upright canes. One of the finest yellow Roses, being a very free bloomer. Sweetly perfumed. Price of strong one-year-old pot plants, 15 cents each; two-year-old plants, 40 cents.

\section{Sunset Rose}

One of the finest of all Yellow Roses.

A strong vigorous grower and free bloomer, highly recommended both for open ground and house culture, which makes it more desirable. The flowers and buds are of extra large size, very full and finely formed and highly perfumed. Color, rich golden amber or gold, elegantly shaded with dark ruby-crimson resembling the beautiful tints seen in a summer sunset. Strong, 20 cents each; two-year-old plants, 40 cents each.

\section{FRANCO RUSSIA}

A new Rose of exquisite kind and color, ranked by many enthusiasts as the best yellow Tea Rose. The flowers are of large size, perfectly double to the center and perfect in shape both in bud and blossoms. The color is magnificentdeep rich lemon yellow, with creamy yellow center with tints of sulphur. It is beautiful beyond description. A strong, healthy grower, and one of the grandest Roses in this book. Price, 15 cents each; two-year-old plants, 35 cents each.

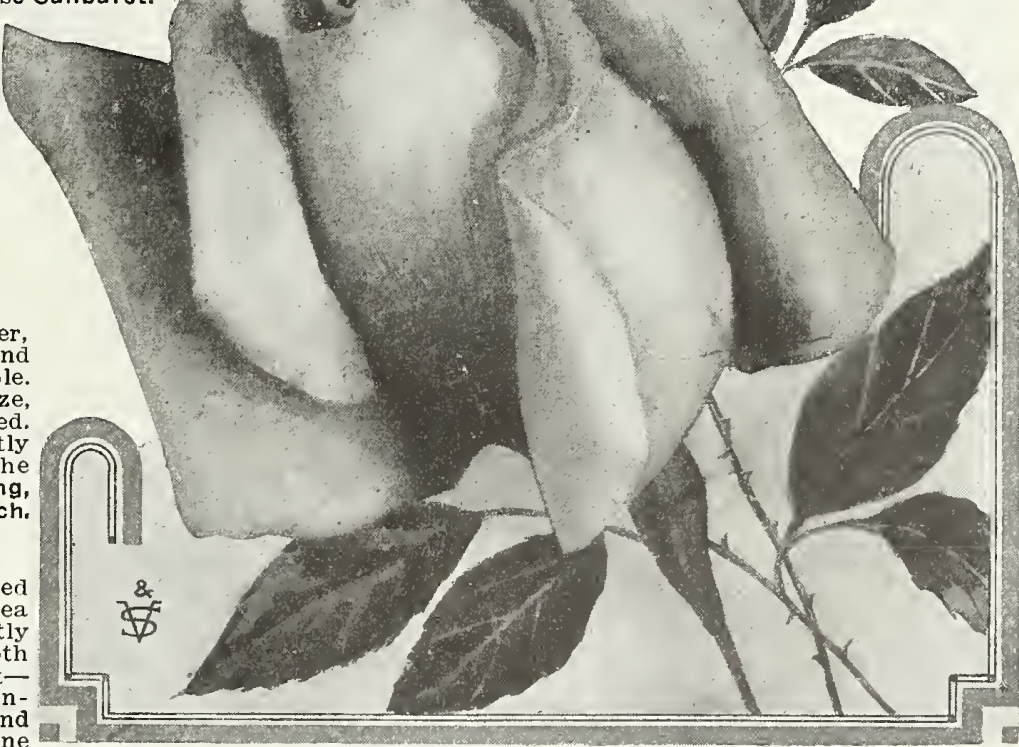

Franco Russia. A Rose particularly attractlve In Its bud stage. 


\section{ROSES-WHITE AND LIGHT SHADES}

\section{MABEL DREW New Hardy Ever-}

A truly magnificent Rose, superb in every respect. It is exquisitely shaped, with smooth, circular petals of great substance, arranged in perfect symmetry. The blooms are large and full, carried on strong and erect flower stalks. The color is a deep cream in the young state, passing to intense canary-yellow in the center as the flower develops. It is a Hybrid Tea Rose with a deliciously refreshing perfume. The flowers are produced continuously and in great profusion. A vigorous grower with rich cedar-green foliage. Price, 15 cents each; two-year-old plants, 40 cents each.

\section{CORNELIA COOK}

The buds are most beautiful, of immense size, and are borne up high on massive stems, and with their round, full, heavy form, carry an air of grace and dignity quite unusual. The flowers are the clearest, snowiest white, and are arranged in the most faultless and symmetrical manner. Cornelia Cook has the largest bud of any white Rose. Price, 10 cents each; large two-year-old plants, 40 cents each.

MOLLIE SHARMAN CRAWFORD New White Ever-

This fine variety is destined to achieve the greatest distinction as a garden Rose. The flowers are splendid, of the largest size, grandly formed. They are snow-white, and of splendid texture. It is of admirable habit, fast-growing and free-branching; foliage dark and heavy, forming a good background for the snow-white flowers. Stems strong. holding the flowers erect. It blooms very freely and is delightfully fragrant. Price, 15 cents each; two-year-old plants, 40 cents each.

\section{MARIE VAN HOUTTE}

of a fine, faultless, straw-yellow color, with the outer petals washed and outlined with a bright rosy crimson; occasionally the whole flower will be suffused with light pink. It grows vigorously, blooms profusely, and is most deliciously scented. Price, 15 cents each; large two-year-old plants, 30 cents each.

\section{KAISERIN AUGUSTA VICTORIA A Superb, Hardy}

This marvelous Rose has had many rivals for the place it still retains as the greatest white Rose in existence. Strong, sturdy grower, flowering with the utmost freedom. It holds first place as the most popular of white Roses for general planting. From early spring until late fall its glorious full-double flowers in all their perfection are produced continuously on long, stiff, erect stems; color delicate creamy-white, with a delicious magnolia-like fragrance, exquisite buds, absolutely hardy. Price, one-year-old plants, 15 cents each; two-year-old plants, 35 cents each.

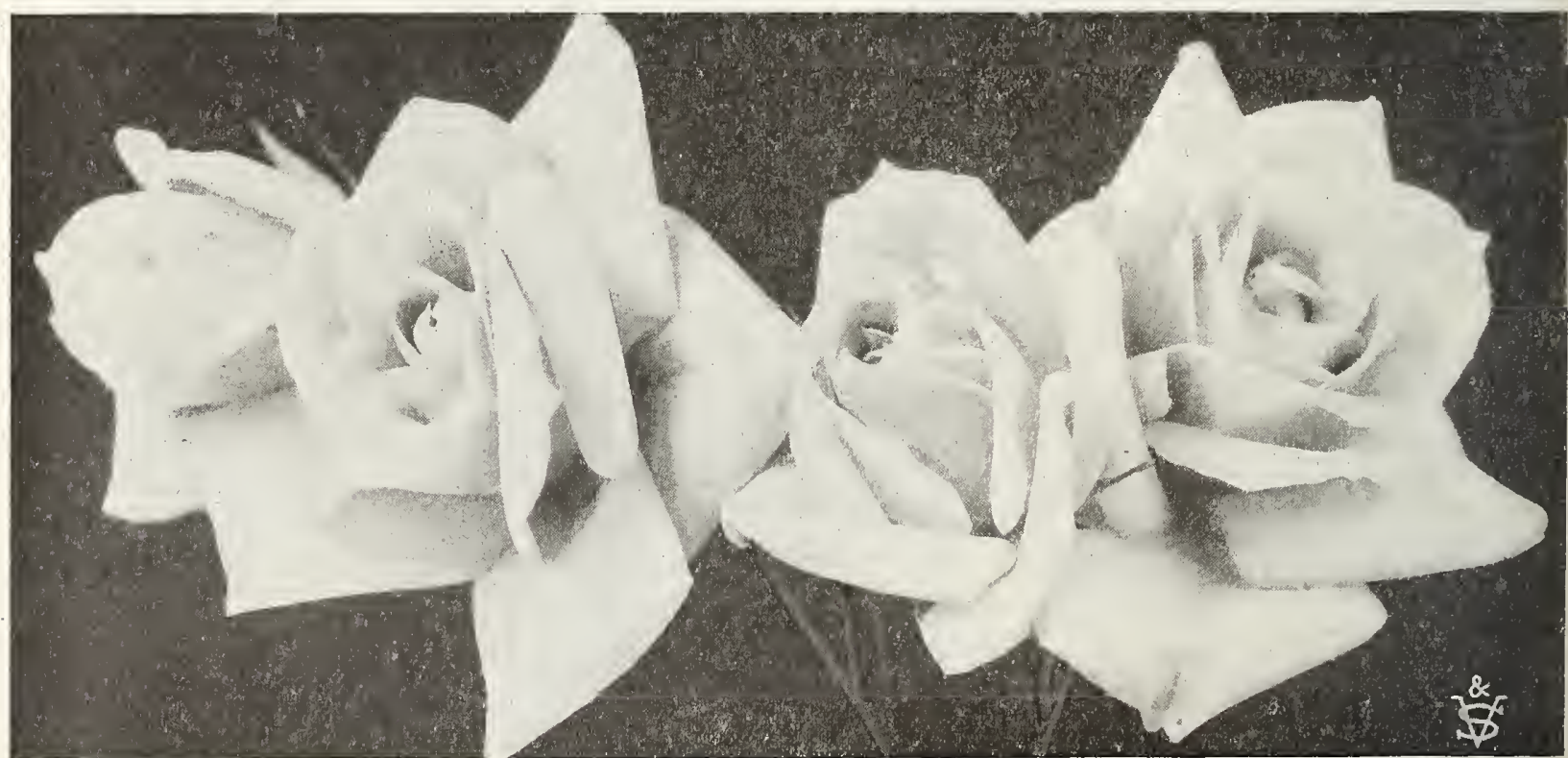

The Summer Blooming Ivory-White Rose Kaiserin; Ivory-white in color; flowers double and delightfully fragrant. 


\section{ROSES-.-Blush and Tinted Shades}

\section{New Rose Wm. R. Smith}

A Vigorous, Healthy Grower, Excellent in Quality and Beautiful in Bloom.

Whether you live East, West, North or South, whether you wish one Rose or 1,000, here is a Rose which has our unqualified endorsement. It will thrive abindantly in almost any reasonable location. The flowers are large, full and double, and most exquisitely formed. The petals are so firm they look like wax, softly curled, colored cream with flesh tint tips, buff yellow base and the center a heart of pink. Perfect buds. The flowers are borne on long, strong stems, just right for making bouquets. Fragrance is delightful. You will admire the foliage, too, deep green leaves on red stems and the new growth of rich garnet; the plant will grow for you vigorously, is among the hardiest in this class and blooms abundantly. Price, one-year-old plants. 15 cents each; two-year-old plants, 40 cents each.

\section{Lady Ursula}

Color a most beautiful shade of flesh-pink, of great substance and good form; petals large, circular and delicately perfumed. A grand grower, producing its round, full blooms in wonderful profusion. Price, one-year-old plants, 15 cents each; two-year-old plants, 40 cents each.

\section{Mad. De Watteville}

The Tulip Rose. The color is a magnificent shade of creamy yellow, richly colored with rosy blush; the largr petals are bordered with bright crimson, giving it a very striking and beautiful appearance. Price, one-year-old plants, 15 cents each; two-year-old plants, 35 cents each.

\section{Eugenie Munchen}

Buds long and pointed, opening up into large, full flowers. Color silvery lilac-rose, graduating into amber-white at the base of the petals. An excellent outdoor Rose. Price, one-year, 15 cents each; two year, 40 cents each.

\section{Madame Joseph Schwartz}

Flowers pure white, tinged and shaded with pale yellow and rosy blush; very full and sweet. Price, one-year, 15 cents each; two-year, 40 cents each.

\section{BESSIE BROWN}

\section{"A Great Outdoor Rose."}

A Grand Hardy Rose. Again we desire to call your attention to this magnificent Rose, which maintains itself as one of the best that has ever been introduced into this country. It has unsurpassed beauty of a totally distinct character, bearing large, full, deep and double flowers profusely in the open ground all through the summer. The color is almost pure white, though sometimes flushed with pink; petals large and of fine form. Price, one-year-old plants, 15 cents each; two-year-old plants, 35 cents each.

Dear Sirs: The plants reached me in fine condition and everything was exactly like ordered. I thank you very much for your careful flling order and for the nice premiums sent. Respectfully, MRS. J. B. CULLEN, Hallville, Texas.

\section{F. R. Patzer}

A most beautiful and distinct Rose of very free flowering character. The blooms are produced with great freedom on stiff stems, and are of large size and substance. The color is creamy-buff, back of petals delicate warm pink; as the petals reflex the color becomes light orange-pink, forming a most charming combination. Valuable for garden culture. Price, one-year-old plants, 15 cents each; two-year-old plants, 40 cents each.

\section{Madame Valere Beaumez}

Cream, yellow and orange are the colors in this queenly Rose. All the tints exquisitely beautiful, form very full and nicely rounded; a strong grower. We feel sure that this Rose will rank in the dozen best bedders. Price, one-year. old plants, 20 cents each; two-year-old plants, 50 cents each.

\section{Mrs. Jas. G. Penny}

This variety sported with us from Radiance some three years ago and is an exact duplicate of that variety in all respects save color. The color is a lovely shade of shell pink with a deep glowing heart of bright pink, which lights up the flower wonderfully. The growth is very vigorous and, like its parent, it is a persistent bloomer, flowering all the time. This variety has been highly commended by all who have seen it in our establishment and we have every confidence in recommending it as a first-class variety. Price, 25 cents each; large, 50 cents.

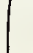

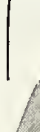$$
\text { and }
$$ 


\section{The Intense Crimson Garden Rose PRINCE DE ARENBURG}

Whatever Else is Planted, Plant This Rose for Wonderiul Flowers

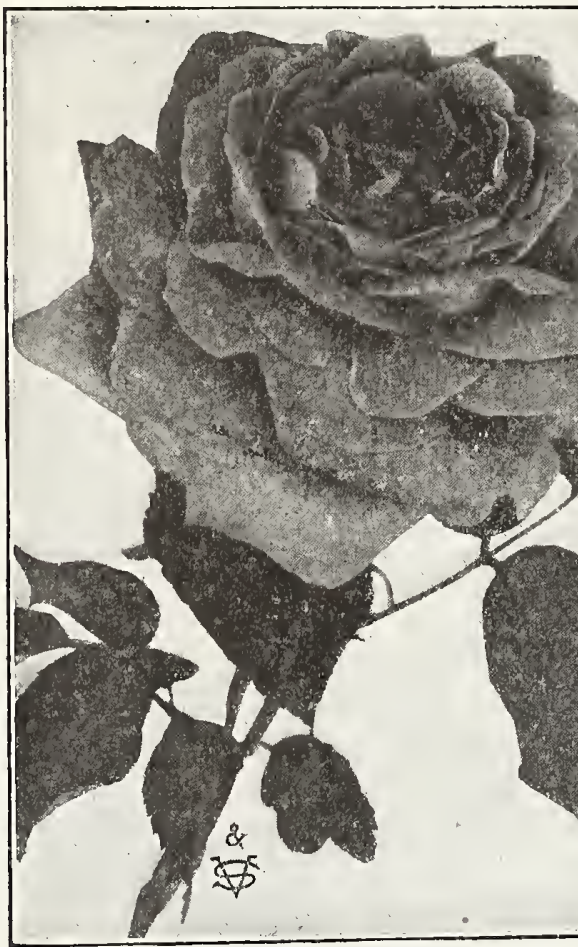

\section{PRINCE DE ARENBERG}

This is one of the newer Roses that has been brought prominently before the public this season and we have not seen a Rose that has met with such universal appreciation by both amateur and professional growers. To those who prefer a Rose with full color we can recommend none more highly than this gorgeous crimson scarlet Rose. It is hardy in practically all localities and as an outdoor garden Rose it has no superior. Of strong, vigorous, healthy growth, branching freely; it produces its wonderful blooms profusely from April until December. Every shoot carries a wellformed flower of exquisite fragrance and splendid lasting qualities. The illustration gives but a faint idea or the richness of this magnificent Rose. Price, one-year-old plants, 20 cents each: two-year-old palnts, 50 cents each.

\section{THREE SOUPERT ROSES}

\section{Price, one-year-old, 10c each; two-year-old, 30c each.}

\section{Clothilde Soupert}

This grand Rose continues to be one of the best and most beautiful varieties for bedding ever introduced. Flowers are deliciously sweet; color beautiful creamywhite, tinged with amber.

\section{Yellow Soupert, or Mosella}

Color is chrome-yellow in the center, getting creamywhite on the edges of the petals.

\section{Mlle. Cecile Bruner}

Rosy pink on rich creamy white ground; a great bloomer; very satisfactory for bedding.

Prince de Arenberg.

"Deepest Velvety or Blackest Crimson;
Enormous Size."

"Deepest Velvety or Blackest Crimson;
Enormous Size."
Dora Hansen "Coloring Almost

This beautiful Rose is one of the best new Roses th introduced. Its beauty and exquisite coloring is almost indescribable. The color is a soft satiny salmon rose; center fawn and outside petals are mon rose; center red, tinted copper and yellow. The flowers are very full and double and bloom early and late. We recommend this Rose very highly, both for garden purposes and for cut flowers. Price, strong, one-year-old plants, 15 cents each; two-year-old plants, 40 cents each.

\section{MADAME SEGOND WEBER}

One of the grandest novelties of recent years; everybody is talling about it, and the more one knows of this wonderful Rose the more he will talk about it, and what is of real value, every bit of talk about Mme. Segond Weber is in praise of her. Rosysalmon or flesh-pink in color, of the general type and color of "My Maryland." The bud is long and pointed, opening into enormous blooms, which deepen its color until fully expanded, when it is as impressive as an "American Beauty." The texture of the Rose is very thick and heavy and the form of the petals peculiarly beautiful. A great garden Rose. Price, one-year-old plants, 15c each; two-year-old plants, 40c each.

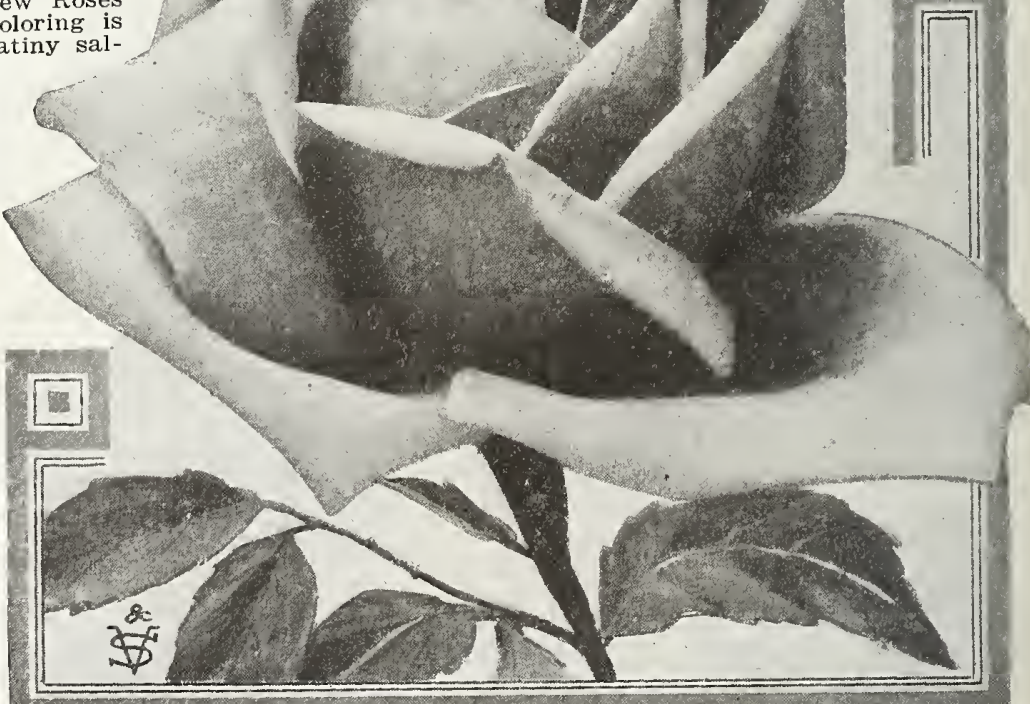

Madame Segond Weber. A Bright Pink Rose of a Beautiful Shade. 


\section{Six Beautiful Cochet Roses-Always Popular}

If you want six of the finest Roses listed in this book, which will produce hundreds of superb flowers throughout the growing season, and producing the kind of flowers one never tires of, order this Cochet set. No matter where you live, they will give you perfect satisfaction. The Cochet Roses are perfectly hardy in every part of the country, even where the winters are most severe, with slight protection. In the more temperate section and in the South they thrive vigorously and bloom most lavishly all summer long, growing into great, strong, lusty bushes which increase in beauty with the passing years

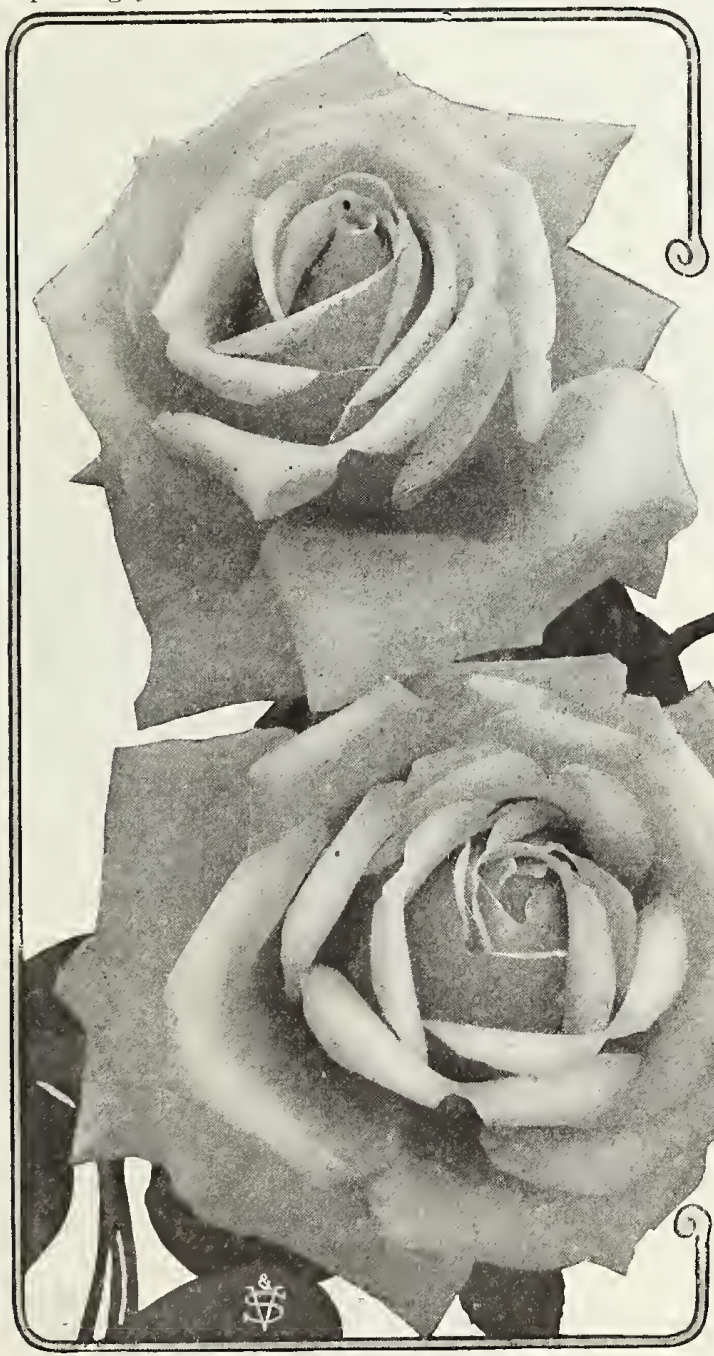

White cochet.

A Rose particularly attractive in its bud stage.
Six Superb New Hardy Everblooming Varieties

Price of Cochet Roses, one-year-old plants, 15 cents each; set of six for 75 cents; two-year-old plants, 35 cents each; set of six for $\$ 1.75$.

\section{White Maman Cochet}

A splendid Rose; has all the good qualities of Maman Cochet. Like some other white Roses, this variety, especially in the autumn, shows pink markings on the outside petals when the flower is in bud. When open the blooms are pure white and entrancingly lovely, large, fragrant, hardy and freely produced.

\section{Crimson Maman Cochet}

\section{(Etoile de France.)}

This well known Rose we have named descriptively Crimson Maman Cochet, because of its vigor of growth, stiffness of stem, heaviness of foliage, freedom of bloom, and hardiness. Bears masses of full, deepformed flowers singly, on long, substantial stems. The color is a new and clear shade of red or crimsonvelvet, brightening in center; of exquisite fragrance. One of the best and sweetest Hardy Hybrid Tea Roses of its color.

\section{Red Maman Cochet \\ (Helen Gould.)}

This is a Rose that will grow and give satisfaction in almost any soil or situation. It produces its splendid flowers in amazing profustion, on long, strong shoots. For vigor and freedom of bloom, thousands of growers regard this Rose as better than American Beauty, and without a peer. The flowers are very full, perfectly double; buds long and pointed. Color is a warm, rosy crimson, hardy everywhere. The exquisite fragrance, beauty of form and hardiness of nature make it ever popular.

\section{Pink Maman Cochet}

This superb Rose is well known as a queen among Roses, one of the best and most beautiful varieties ever grown, and quite hardy. The flowers are of enormous size, very full and of great depth and substance. Color, rich coral-pink, elegantly shaded with rosy crimson; has broad, thick, shell-like petals and makes superb long-pointed buds; immense bloomer, and flowers the whole season. Deliciously sweet and a hardy, vigorous grower. It ranks among the very finest hardy everblooming Roses.

\section{Yellow Maman Cochet}

We continue to regard this grand kind as absolutely the best, everblooming yellow Rose. It is ideal for open ground culturea typical Cochet Rose, with gracefully molded buds, flowers magnificent when open, on stiff, strong stems. This lind is identical in every way with Pink and White Cochet, except the color of the flower, which is deep sulphur-yellow.

\section{Blush Maman Cochet}

(Wm. R. Smith.)

This magnificent, variety is an American-raised, pedigree seedling. It inherits hardiness, constitution, fine habit, grand foliage and superb fowers. Where there are so many good qualities, it is difficult to emphasize the leading one, but in this variety we would name its ability to resist disease. The color is a deep ivory-white overlaid with a good, bright shade of pink. As a summer Rose it ranks with the best.

SPFCIAI OFFER. One each of Pink, Whlte, Red, Yellow, Blush and Crimson Cochet, strong plants, for 75 cents; SPECIAL OFFER: two of each, 12 in all, $\$ 1.25$. Two-year-old plants, one of each, 6 in all, $\$ 1.75$, by express. 


\section{BEAUTIFUL YELLOW ROSE LADY HILLINGDON}

"Everybody Can Grow It."

It has long willowy stems that are in no sense weak, as the buds are held upright; has a long slender pointed bud of brilliant, deep golden-yellow, and a striking peculiarity of this Rose is that each day the golden-yellow color becomes deeper yellow and more intense, unlike all other yellow Roses of which we are familiar, as invariably the tendency after being cut is to get lighter in color. Price, one-year-old plants, 15 cents each; two-year-old plants, 40 cents each.

\section{Perle des Jardins}

\section{Pearl of the Garden.}

The color is a clear golden yellow, of a beautiful shade, and is entirely distinct from any other variety; the flowers are large, full, of globular form, with great depth and substance, richly perfumed, and very beautiful in every way. This magnificent Rose still holds its position as one of the most exquisite and beautiful of its color ever introduced, and the demand for it is constantly increasing as its great value becomes known. It is ideal for cutting purposes. fine garden Rose, being strong and thrifty. Price particularly plants, 10 cents each; two-year-old plants, 30 cents each.

\section{Helena Cambier}

of unusual beauty, with large, double, beautifully formed flowers, the colors are varying, ranging from salmon-rose to coppery rose; very often a handsome saffron hue. As the flowers expand, the colors become lighter. A most remarkable sort in every respect and one to which we give our highest endorsement. Good everywhere, especially in the South. Price, one-year plants, 15 cents each; two-year, 40 cents each.

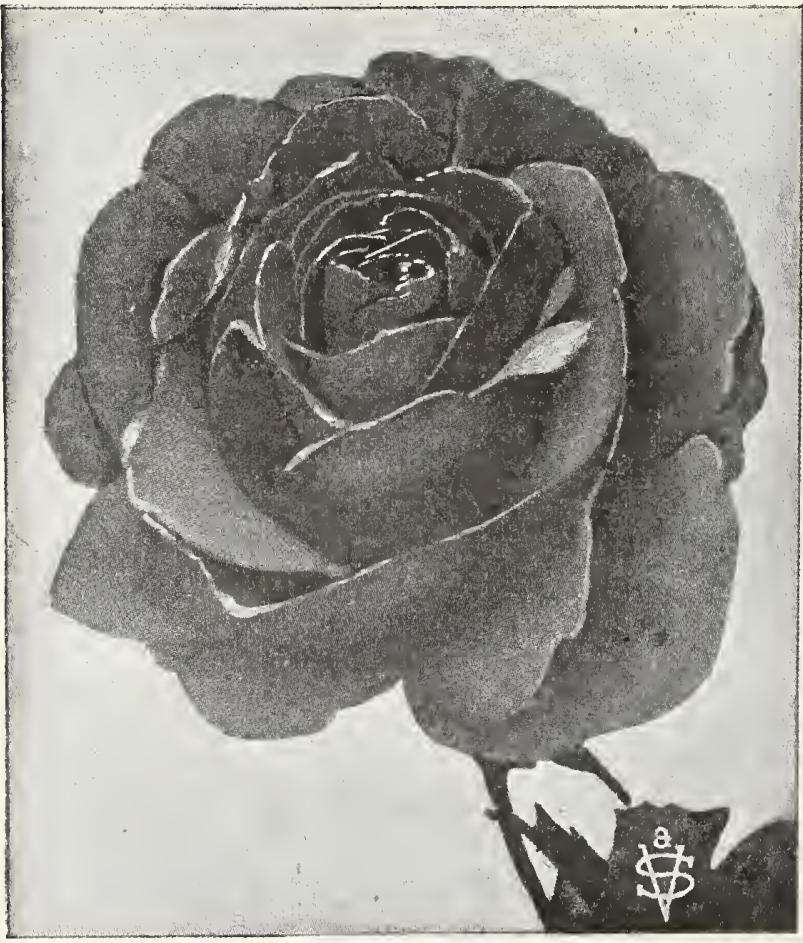

Virginia R. Coxe.

"A Fine Bush Rose of a Fiery Color."
Gentlemen: I re ceived the Roses which I ordered from you in good condition and am delighted with them; also I thank you for the extra Rose which you included in the order. Yours truly, MRS. D. N. SCOTT, Stone, Bluff, Okla. 


\section{THE BEAUTIFUL LA FRANCE ROSES}

The La France Roses are of the highest merit, and each member of the family has particularly strong points. Practically hardy everywhere, they are splendidly adapted for general planting.

Price of all the La France Roses, 15 cents each, 4 for 50 cents; two-year-old plants, 40 cents each.

LA FRANCE. This is probably the most popular Rose in cultivation. Both buds and flowers are of lovely form and grand size, exceedingly sweet: color fine peach-blossom, elegantly clouded with rosy flesh. Begins to bloom while very small, and continues bearing until stopped by freezing weather.

WHITE LA FRANCE. A seedling of La France; extra large, full, deep, pearly white flowers, delicately shaded with soft rose; exquisitely beautiful and delightfully fragrant.

RED LA FRANCE. This is a superb Rose, belonging to the Hybrid Tea class, and closely resembles La France, but much deeper in color and a better grower; the flowers are extra large, exceedingly beautiful, very double and full and deliciously sweet color lovely rose-pink, very deep and exquisitely shaded; a constant bloomer.

THE STRIPED LA FRANCE. An elegant new Rose, closely resembling La France in form and substance, but the flowers are distinctly striped with pearl-white and satin-rose.

SPECIAL OFFER-Set of 4 charming La France Roses, 1 -year size, 50 cents, postpaid; 2 -year size, $\$ 1.40$ by express.

\section{Florence Forrester}

FLORENCE FORRESTER. Clear snow-white with a lemon tinge; as the flowers age they become a pure white, the blooms are even larger than Paul Neyron. Its habit is absolutely perfect, and the freedom with which it flowers is marvelous. We consider this Rose the grandest of all whites for bedding. For size and substance has no equal. Is very sweetly perfumed. Beautiful long pointed buds on tall stiff stems. An excellent Rose for cutting. Price, one-year-old plants, 15 cents each; two-year-old plants, 35 cents each.

\section{AMERICAN BEAUTY}

The World Famous Rose.

If any Rose has earned the title of the "National Rose," it is the American Beauty. "Wherever this Rose is known, it is the queen, and it surely deserves the name. Beautiful, fragrant, enduring, it is and always shall be, the Queen of Roses. In size, color and form it has no equal. This Rose has become as famous as the Marechal Niel. The flowers of this grand Rose are so eagerly sought that they sell in the flower stores of the larger cities during the holiday season at the extravagant price of from $\$ 1.50$ to $\$ 2.00$ for a single bud or flower. Indeed, the market is never fully supplied with them even at this high price. It is because of its large size, rich color and delicious fragrance. It is a hardy Rose of the largest size, having the everblooming qualities of the Tea Rose with the delicious odor of the Damask or Moss Rose. It is the sweetest of all Roses. In color it is a deep brilliant red, shading to a rich, carmine crimson. American Beauty is, like Marechal Niel, difficult to start from small plants, therefore we advise our customers to buy strong plants of it. This Rose will never be sold cheaply, for the reason that it is hard to propagate. Prlce, large 2-year-old plants, 50 cents each; extra large 3 -year-old plants, $\$ 1.00$ each.

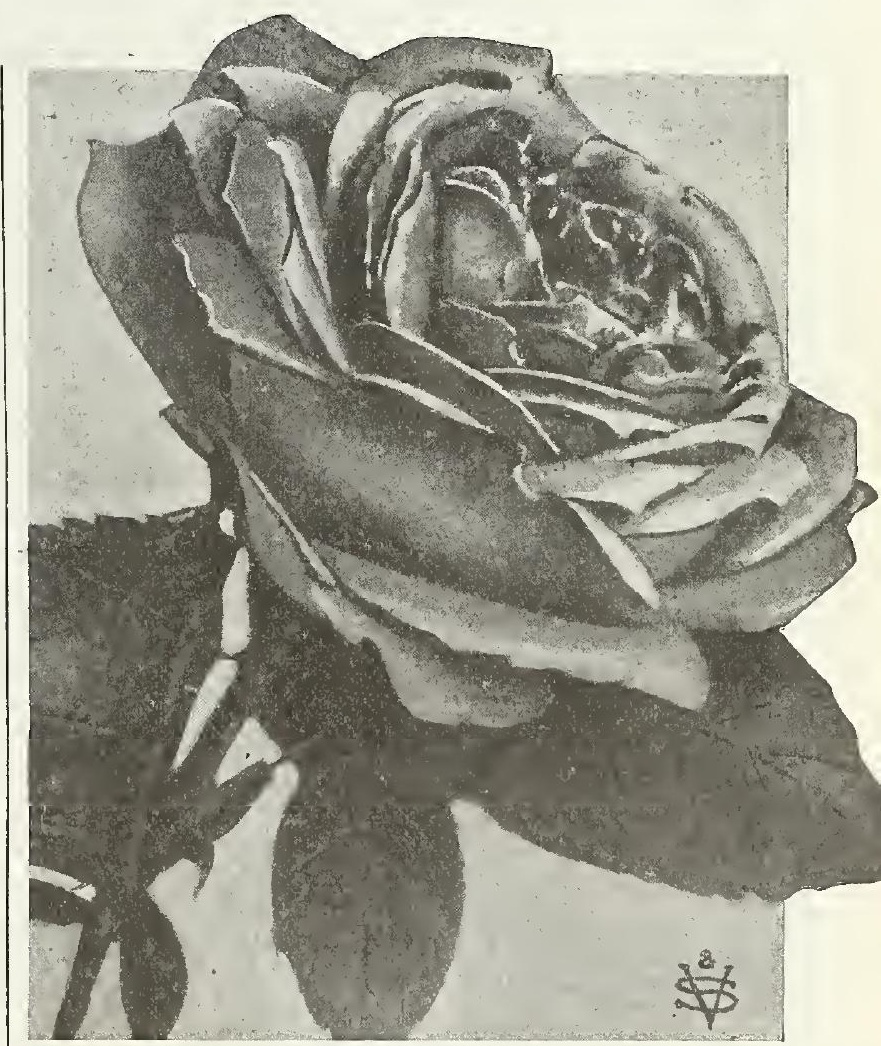

American Beauty.

Considered the Largest Flowering Rose Grown. 


\section{Dwarf Polyanthus Roses}

Plant Baby Ramblers for Bright Edging. They Bloom Unceasingly.

These are entirely distinct from the larger flowered Roses and there is a place for both in every garden, being so hardy and adapted to so many uses. Masses of 25 or more together will be found to make a very effective planting.

\section{The Famous Crimson} Baby Rambler

One of the most useful and ornamental Roses yet introduced. It blooms in immense clusters similar to Crimson Rambler, every day in the year, but grows only 20 inches high. Better than an azalea, it is superb for single specimens, dwarf hedges and for bedding. The color is clear and brilliant ruby-red; foliage dark and glossy. Free from insects and absolutely hardy everywhere.

\section{Pink Baby Rambler Orleans Rose.}

The showiest and prettiest of the pink "Baby" Roses: this charming and dainty little variety is of beautifully rounded habit and is a huge bouquet of brilliant bloom, deep cerise, with showy center of pure white, florets not crowded, but of beautiful arrangement.

\section{Double White}

\section{Baby Rambler}

A most beautiful companion to the Crimson Baby Rambler, growing to the same height, and bearing great masses of double, pure white flowers, covering the plant as with a mantle. The Roses are delightfully scented, reminding one somewhat of a hyacinth.

\section{Baby Tausendschon}

A dwarf form of the Climbing Tausendschon or Thousand Beauties. It has all the characteristics of the climber in the charm of its flowers, but blooming the entire season. Flowers firm, white, delicately flushed pink, changing to deep rosy-carmine.
Price of all Baby Ramblers listed on this page: One-year-old plants, 15 cents each, $\$ 1.50$ per dozen; two-year-old plants, 35 cents each, $\$ 3.00$ per dozen.

Erna Teschendorff

The color of the flowers is the brightest red. The flowers are large and very double and are produced in constant succession throughout the whole season.

\section{Mrs. Wm. Cutbush}

of dwarf growth, producing in constant profusion flowers of pale pink, borne in huge trusses throughout the entire summer and autumn. Hardy.

\section{Bonnie Belle}

Enormous trusses of dark cherry-red flowers. Unusually long buds ior a Polyantha. Worthy of tilal.

\section{Geo. Elger}

A superb Polyantha Rose with just sufficient of Tea Rose blood to make it different from any in its class. It produces great quantities of lovely little buds of golden yellow, opening into miniature symmetrical Roses. Each bush is so loaded with blooms that they resemble a huge bouquet. Like all Roses of this class, it is free in growth and bloom, blooming all summer. Hardy everywhere with some protection. Foliage bright, attractive green. Excellent companion for the Baby Ramblers.

\section{Jessie}

This new Baby Rambler is an ideal Rose for massing, bedding or for pot culture. The flowers, which are produced in huge clusters, are of a bright cherry-crimson color which does not fade. Superb. The best of all the Baby Ramblers for pot culture.

\section{VESTAL'S "SUNNY SOUTH"}

Set of four distinct Everblooming Roses shown on next page.

In the "Sunny South" Collection of Everblooming Roses named below we offer four choice varieties especially adapted for outgdoor bedding. They combine the greatest variety of form and richness of color it is possible to get in that number. All are free blooming and delightfully fragrant. For vigorous growth, freedom of bloom combined with hardiness, fragrance, healthy and abundant foliage, they are unexcelled. The smallest or third size are sturdy plants from 3-inch pots and will, under ordinary conditions, give an abundance of bloom this season, but the larger sizes will, of course, bloom earlier, more profusely and should produce larger flowers on longer stems.

\section{Mrs. George Sawyer}

It is without question the most remarkable of all pink Roses. It has a shining, intense deep pink color possessed by no other Rose. It is a fine grower, free bloomer, good size and form, fragrant and in a class by itself as to color. Price, one-year, 15 cents; two-year, 40 cents.

\section{Crimson Queen}

A very strong upright grower, flower large and full. Color a rich bright velvety crimson. A grand garden Rose, as it is always in bloom. One-year, 20 cents; two-year, 40 cents.

\section{Madame Segond Weber}

Rosy-salmon, deepening in color as its long, pointed buds open and expand into blooms of enormous size, with petals of heavy texture and beautiful in form. One-year, 15 cents; two-year, 40 cents.

\section{Florence Pemberton}

Distinctive creamy white, shaded Rose; petals bordered rosy salmon; flowers large, very full and beautifully formed. Soon produces large magnificent bush constantly in bloom. One-year, 15 cents; two-year, 40 cents.

We will supply one each of the Four Sunny South Roses in one-year-old plants, for 50 cents; one each of these fine Roses in two-year-old plants for $\$ 1.50$; or they can be purchased separately at prices named. 


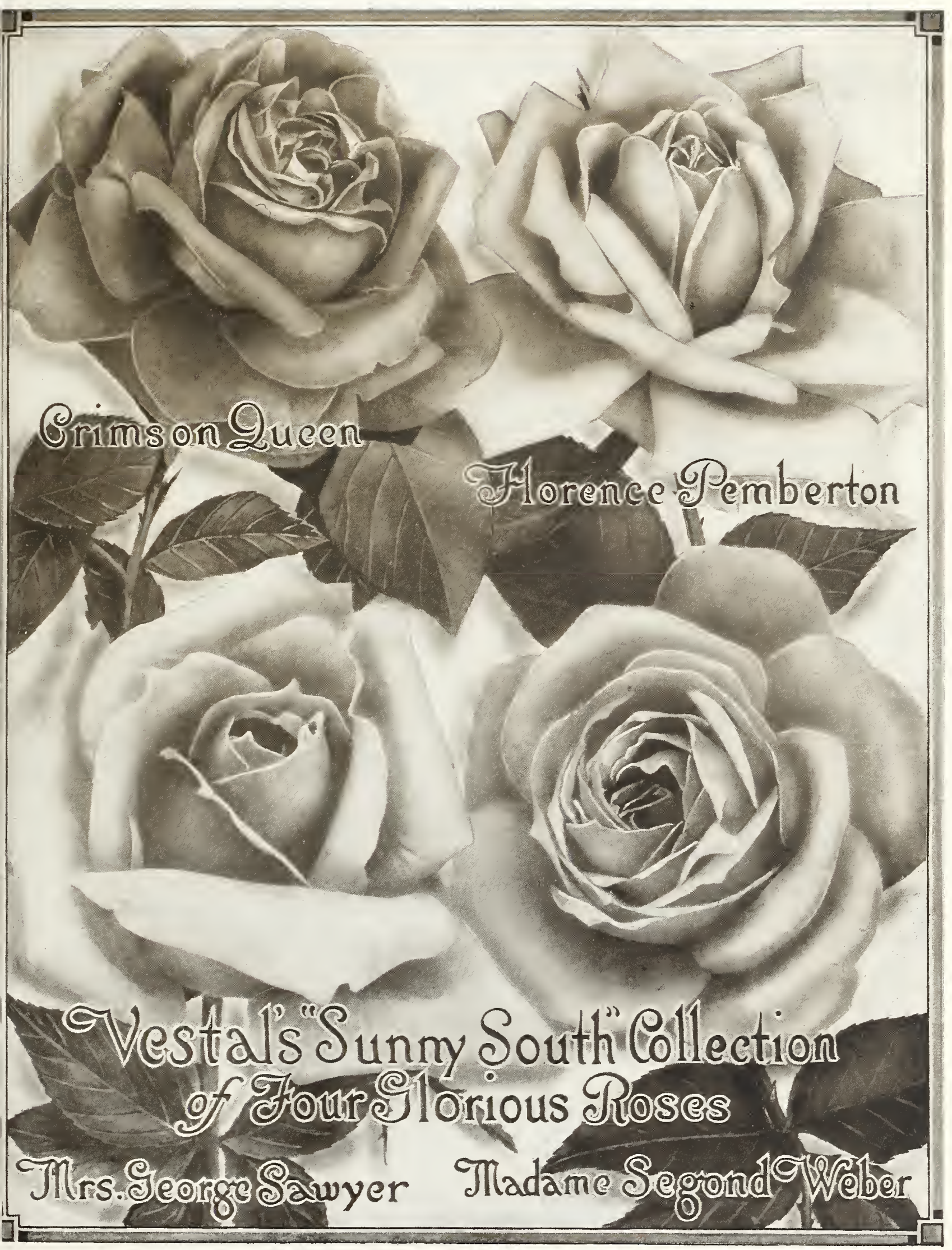




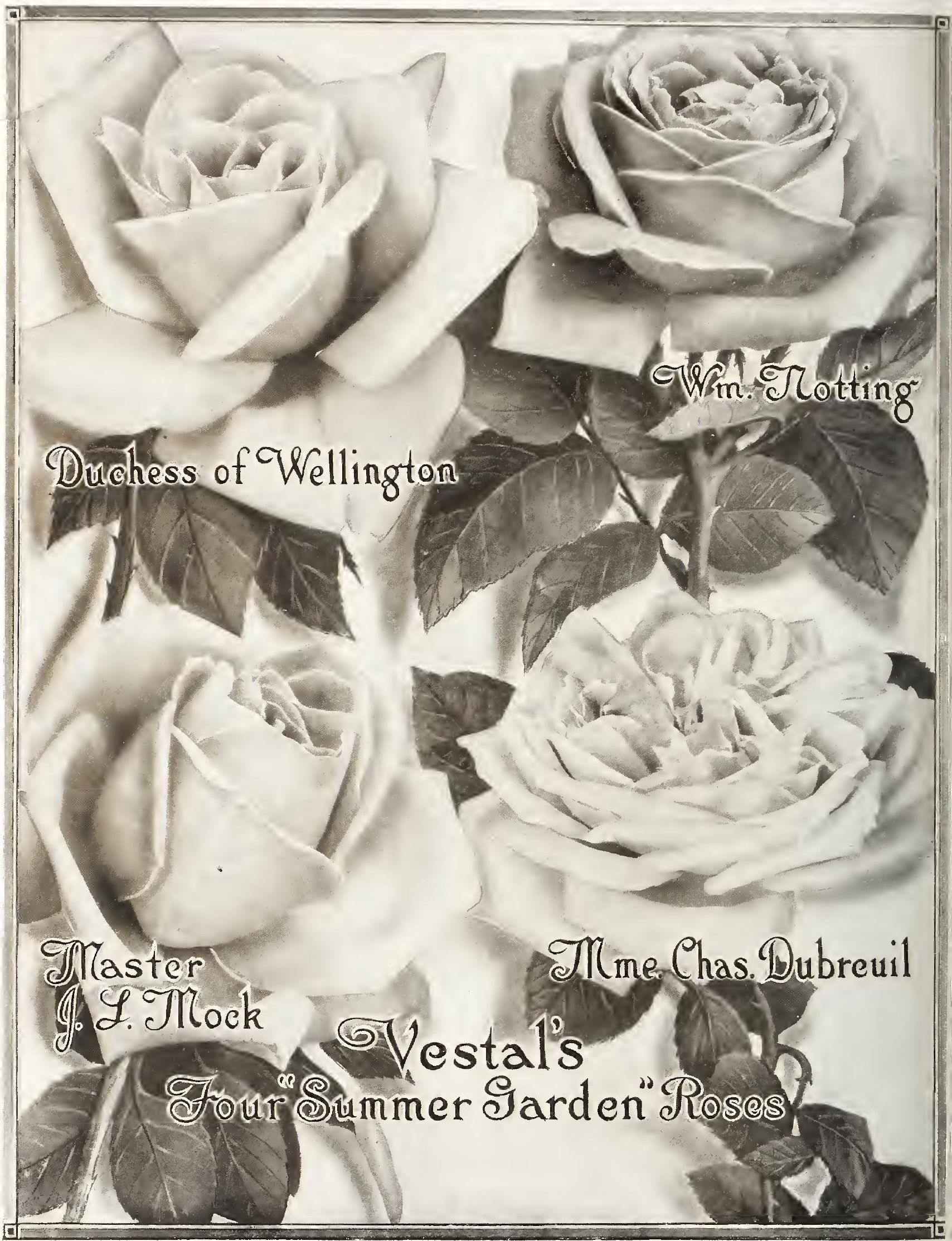




\section{Vestal's Four Summer Garden Roses}

\section{Jonkheer J. L. Mock}

Like the rest of the Rose-growing world, we are enthusiastic in praise of this famous Rose, which gained the distinction of being winner of the Grand Prize-Highest Award-at the International Rose Show held at Paris. The color is carmine on the outside, which contrasts beautifully with the lovely imperial pink of the inside of the flower as the petals unfold and curl, and the exquisite blooms are produced freely on stiff, erect stems. The flowers are very large, perfectly formed and highly perfumed. You should plant an entire Rosebed of this one kind. Prlce, one-year-old plants, 20 cents each; two-year-old plants, 50 cents each.

\section{Florence Pemberton}

Distinctive creamy white, shaded rose; petals oordered rosy salmon; flowers large, very full and beautifully formed. Soon produces large magnificnt bush constantly in bloom. Strong grower and one of the best distinctive Hybrid Teas. Price, 15 cents each; two-year-old plants, 40 cents each.

\section{William Notting}

"A Grand Bold Flower; Coral-Red; Center Bright Salmon."

In all the range of colors among Hybrid Teas it stands unique and quite distinct. Its color is coral-red center bright salmon; flowers large, full and of splendid form, a grand, bold, well-built flower, perfect in shape and form, of the most modern type, extra perpetual flowering. A grand exhibition and garden Rose, with a perfect habit of growth, the most attractive color; a really superb variety; very fragrant. Price, 20 cents each; two-year-old plants, 50 cents each.

MADAME CHARLES DUBREUIL, Growth vigorous. The color is a salmon-rose, shaded carmine on the reverse of the petals. Very large, full and of flne form. Price, 1-year, 20c; 2-year, 40c.

Gentlemen: Just received the shipment of Roses and they are in perfect condition. I am so very proud of them and thank you so much for the extra

Roses you sent. My other roses are growing and with but one or two exc e p t i o $\mathrm{ns}$. they have all put on new leaves. Again

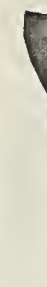

We will supply one each of the Four summer Garden Roses in 1-year. old plants, for 50 cents; one each of these fine Roses in 2-year-old plants for $\$ 1.50$; or they can be purchased separately at prlces named. 


\section{MADAME JULES GROLEZ}

Red Kaiserin Augusta Victoria.

One of the very best of the new Roses, and one that has so many good qualities that we are quite certain it will find a place in the garden of every flower lover. It has been thoroughly tested by us and we have formed such a high opinion of it that, this year, we have grown an unusually large stock in order to give the Rose the widest possible distribution Mad. Jules Grolez is an exceedingly free-blooming variety, with very large, finely formed flowers. The color is distinct and charming shade of cherry-red. The fine form and attractive shape of the flowers make them excellent for cutting. Like Kaiserin Augusta Victoria, Mad. Jules Grolez is a Rose of great value for open-ground culture. It is a remarkably strong growing variety, as hardy as the Hybrid Perpetuals, free-flowering and in every way excellent. Price, one-year-old plants, 15 cents each; two-year-old plants, 40 cents each.

\section{Crimson Queen}

"The Greatest Advance In High Colored Roses." (Summer blooming, hardy with protection). The color of this Rose is intense crimson, changing to crimson-maroon. It is extraordinarily free growing and free blooming. A very superb variety. The flowers are perfect in form and shape, being full and double to the center and having long stems for cutting. A strong robust grower. A Rose that will take the place of every other Rose in this color, and it is the greatest advance in high colored Roses yet raised. It is delightfully sweet scented. Price, one-year-old pot plants, 20 cents each; two-year-old piants, 50 cents each.

\section{Robin Hood}

This new Rose has a glorious rosy-scarlet color that is at once soft and bright and lasting; the bloom is full and of beautiful build. It is a grand grower, heavy caned and profuse in foliage; flowers very freely produced. Price, 15 cents for one-year plants; 40 cents for two-year plants.

\section{Mrs. B. R. Cant}

This Rose is an extremely strong-growing variety, producing heavy stems, with large, healthy foliage and flowers almost the equal and style of Helen Gould, but more double; deep rose, with silvery rose center. A bright, clear garden Rose, and a prolific bloomer, especially good for outdoor cultivation. Delightfully fragrant. Price, one-year-old plants, 15 cents each; two-year-old plants, 40 cents each.

\section{Clara Watson}

Rich salmon-pink, with very graceful flowers, resembling Bridesmaid in form and produced in remarkable profusion. The buds, which are supported on long stems, are very beautiful. 15 cents each; two-year-old plants, 40 cents each.

\section{HOOSIER BEAUTY}

"Recognized as One of the Great Introductions."

The color is a deep rich velvety crimson. The velvety blooms with huge petals form a revelation in coloring. The flowers are faultless and perfect, large and quite full, beautifully arranged and of wonderful depth and substance. It is a Rose of unusual make-up. The growth is sturdy, uniform and perfect and the blooms which are held rigidly upright are of the most delicate and sweet perfume. It is a continuous bloomer and is a decorative Rose of the highest value, and has been recognized as one of the great introductions for garden and cut-flower purposes of recent years. Price, 20 cents each two-year-old plants, 60 cents each.

\section{White American Beauty}

The best White Rose in existence. Pure snow-white, with long buds and immense, perfectly double flowers, 4 to 5 inches across, with wax-like petals and very durable. It is one of the most continuous-flowering Roses in this excellent class. Hardy everywhere that Roses grow. Good for cutting and for garden decoration. The Garden, England, says: "White = American Beauty is universally admitted to be the finest White Rose in cultivation." Price, one-year, 25 cents; two-year, 60 cents.

\section{Mrs. George Shawyer}

This is one of the newer varieties introduced by the grow ers of Lady Hillingdon. We have not seen a Rose that has met with such universal appreciation by both the amateu and professional grower, and has won awards in almost every place shown since it was introduced, both in this country and Europe. The color is one very hard to describe, being a shade of brilliant clear rose or bright peach-pink. It is a wonderful grower and bloomer, producing great numbers of strong shoots, each shoot tipped with a bud. The flowers are very large, well formed and full, petals of good substance. A very, fine garden Rose, as well as a forcing Rose. Price, one-year-old plants, 15 cents each; two-yearold plants, 50 cents each.

\section{Mad. Abel Chatenay}

Grand Perpetual-Blooming Rose.

This splendid Rose is one of the very best of its colorrosy-carmine, with darker shade. It does remarkably well in the open ground, has wonderfully beautiful flowers, which are full, deep and double. A very hardy Rose. Chatenay is a strong grower and free bloomer and has won friends wnerever it has been planted. We have a large stock of superio quality, and urgently recommend all our customers to include Mad. Abel Chatenay in their Rose orders for this spring. Price, 15 cents each; two-year-old plants, 40 cents each.
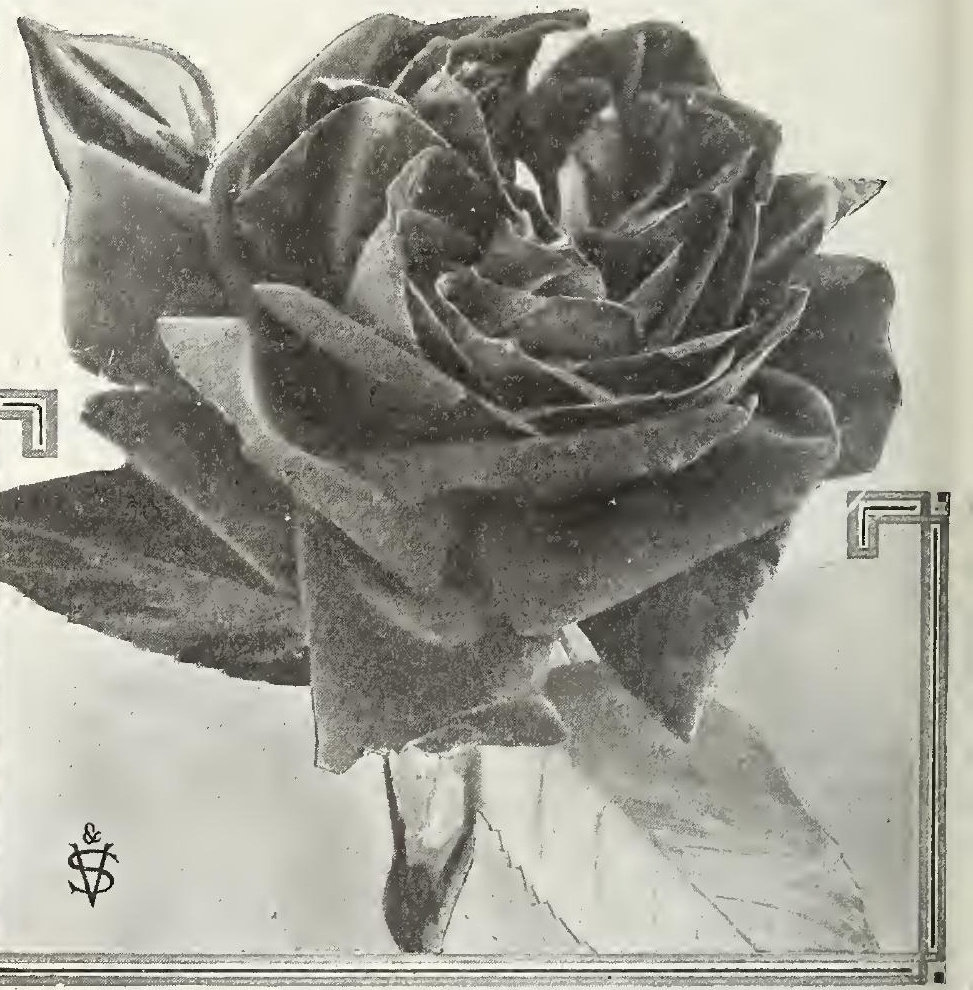

Hoosier Beauty is a New Rose of Wonderful Brightness and Charm. BrIIIlant Crimson In Color. 


\section{MADISON---Immense Flowers of Clearest Snowiest White}

Madison is one of the very best of the new Roses, and one that has so many good qualities that we are quite certain it will find a place in the garden of every fiower lover. It has been thoroughly tested by us and we have formed such a high opinion of it that, this year, we have grown an unusually large stock in order to give the Rose the widest possible distribution. The buds are most beautiful, of immense size, and are borne up high on massive stems, and with their round, full, heavy form, carry an air of grace and dignity quite unusual. The flowers are the clearest, snowiest white, and are arranged in the most faultless and symmetical manner. The fine form and attractive shape of the flowers make them excellent for cutting. Like Kaiserin Augusta Victoria, Madison is a Rose of great value for open-ground culture. Price, oneyear-old plants, 15 cents each; two-year-old plants, 40 cents each.

\section{Mlle. Franciska Kruger}

A favorite Rose for the garden and the most satisfactory variety in its color. The coloring is strikingly handosme, a blending of deep yellow with coppery yellow and buff shading. Fine buds and splendid flowers which remain in good condition a long time. Price, 10 cents each; two-year-old plants, 40 cents each.

\section{Meteor}

An Old Favorite, Always in Demand.

Notwithstanding this famous old hardy favorite has long been grown, it still may be regarded as the most beautifully formed, brilliant velvety crimson variety now in cultivation. Beautiful buds and flowers, very large and exquisitely made. The bush is remarkably vigorous in growth, perfectly hardy and constantly in bloom. Price, one-year-old plants, 15 cents each; two-year-old plants, 40 cents each.

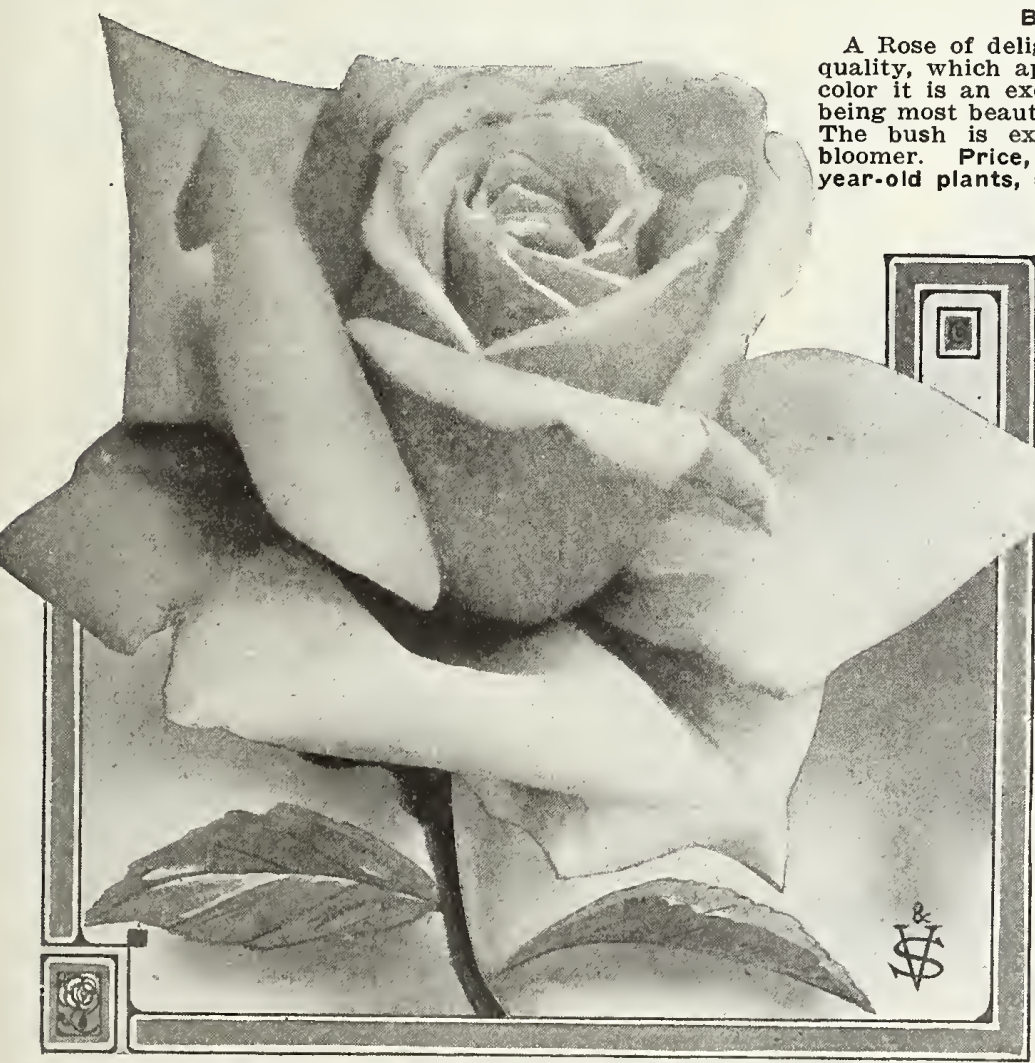

The comblnation of colors In the salmon-yellow Rose Ophella makes it a highly decorative varlety.

\section{William Shean}

"Very Free Blooming and DistInct."

This is one of the most unique of Roses, both in colortones and contrast. The flowers are a beautiful pure pink, with delicate tinting. The flowers are of immense size and substance, and of perfect form. The plant makes a sturdy, well formed bush that will give satisfaction anywher $\theta$. Very free blooming and distinct. Price, strong one-year-old plants, 20 cents each, three for 50 cents; two-year-old plants, 40 cents each.

\section{Suzanna Blanchet}

One of the best Roses. Outdoors it grows splendidly, and blooms with such freedom as to make it one of the most satisfactory Roses for general cultivation. Color beautiful pale flesh, passing to silvery white, shaded with fine rosy amber; large finely pointed buds. Price, one-year-old plants, 10 cents; two-year-old plants, 40 cents each.

\section{My Maryland}

Beautiful In Bud and Flower.

A Rose of delightful color, distinctive shape and superfine is an exquisite shade of pink, the buds and flowere most beautifully formed and borne on long, stiff stems. The bush is extra strong, hardy and a most prodiglou: bloomer. Price, one-year-old plants, 15 cents each; twoyear-old plants, 50 cents each.

\section{OPHELIA}

This new Rose has the brightest future in our estimation, of any Rose introduced for the last quarter century. The color is one so difficult to describe that any description can only be a partial one, and gives but a faint idea of the superb beauty and richness of the shades. Salmon-flesh, shaded with rose. Buds of unusual attractiveness, opening full and double. The illustration conveys but a faint idea of It: beauty and formation, which is of large and perfect shape. Habit excellent, growth strong, produces flowers on long stems, well up above the foliage, and in great profusion all summer. Hardy in almost all localities. Grand for forcing or outdoors. Prlce, 20 cents each; two-year-old plants, 50 cents each, by express.

\section{For Hedge Purposes}

American Pillar makes strong canes that grow upright several feet before bending over, therefore a magnificent hedge can be made with this variety without the necessity of providing a support. In May the entire hedge become covered from base to tip with the exquisite, delicately fragrant blooms, entrancingly beautiful. Dozen rates, 1-year, 12 for $\$ 1.50$; 2-year, 12 for $\$ 4.00$. 


\section{PRESIDENT TAFT}

It is without question the most remarkable of all pink Roses. It has a shining, intense deep pink color possessed by no other Rose. It is a fine grower, free bloomer, good size and form, fragrant, and in a class by itself as to color. Mr. Frank Good, who is probably familiar with more Roses than any man in America, says: "Talk all you want to about the Rose President Taft, and then you will not say enough. Price, one-year-old plants, 15 cents each; twoyear-old plants, 40 cents each.

\section{RHEA REID}

After many tests and observations we are prepared to say there is no crimson or scarlet Rose better than this varlety and for outdoor cultivation it ranks at the very top of the list. The flowers are exquisitely formed, are delightfully fragrant and the color is crimson-scarlet. Growth is wonderfully strong, sturdy and healthy, which is the lmportant feature after all. It will succeed anywhere and is hardy. A great Rose in the fullest sense. Price, one-year-old plants, 15 cents each; two-year-old plants, 40 cents each.

\section{MADAME JENNY GILLEMOT}

The Yellow Kaiserin.

Buds long and pointed, deep saffron yellow, opening canary with dark golden shadings; blooms large, petals immense: opens very freely; a fine upright grower of branching habit. Exquisitely beautiful; very large in size; bud very long and pointed. Price, one-year-old plants, 20 cents each; two-year-old plants, 50 cents each.

\section{Alice Roosevelt}

\section{An Improved Mme. Chatenay.}

A rare and very beautiful Rose of novel and distinct color. rich pink or rose flushed with orange and fawn. Flowers large, well filled and very fragrant. A strong, healthy grower and free bloomer; quite hardy and fine for the yard or garden. Price, 15 cents each; two-year-old plants, 40 cents each.

\section{Edith Part}

A Rose with a novel and entirely distinct blend of color, which is a rich red with a suffusion of deep salmon and coppery-yellow with a deeper shading in the bud stage of carmine and yellow; very sweetly scented. Prlce, one-year, 15 cents; two-year, 50 cents.

\section{Gen. Arnold Janssen}

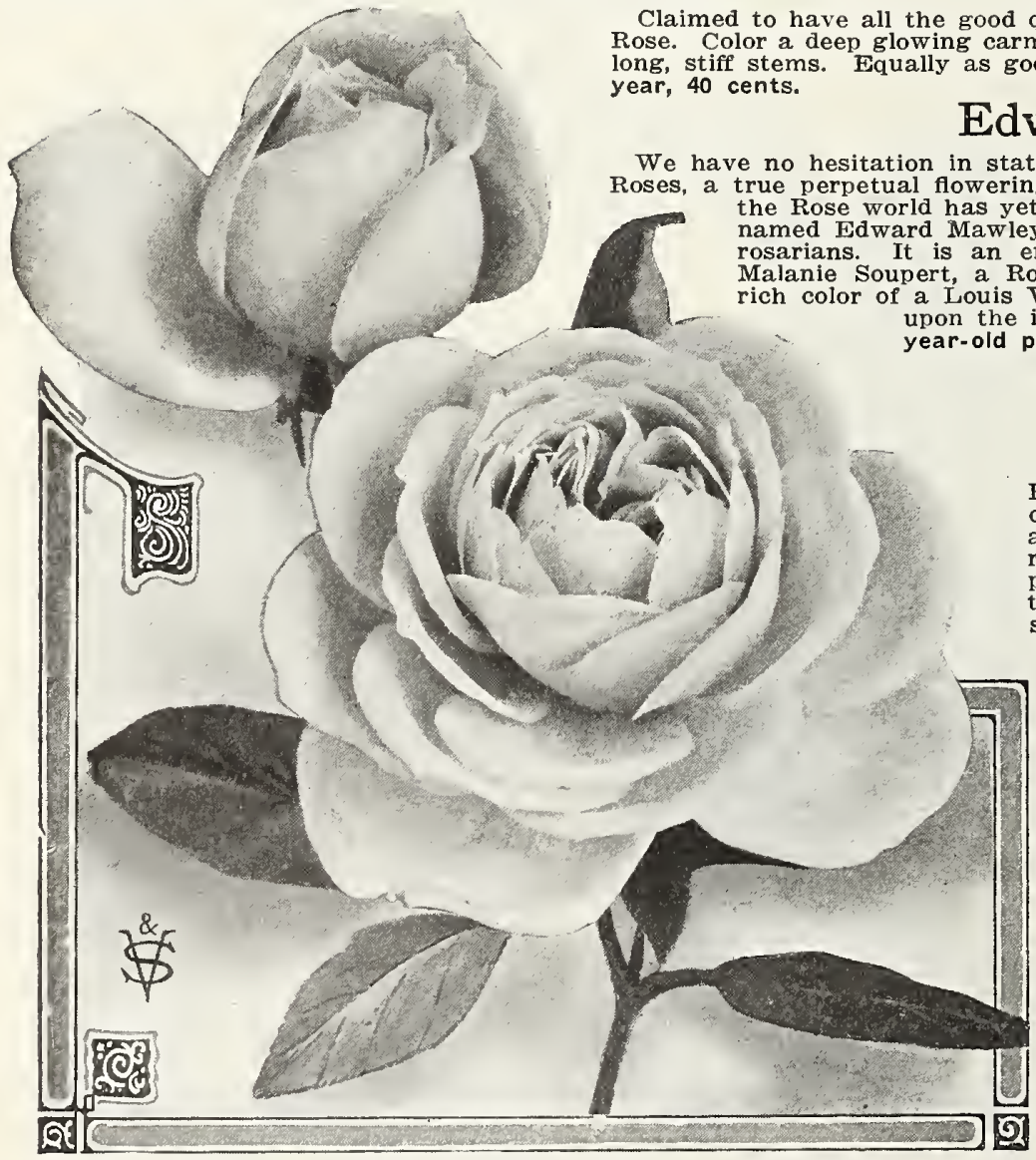

The Grand Rose Wellesley-Flowers Brlght Plnk.

\section{WELLESLEY}

Wellesley is a Hybrid Tea Rose, as fine as a Rose can be; has good-sized flowers and blooms continuously. The bud, when flrst opening, is a beautiful shade of bright pink and the flower retains this perfect coloring until it drops its petals. Blooms continuously the whole season
through, and gives fine stems for cutting. Will stand the winters any place south of the Ohio River, but north of that line lt should be protected. It is a very vigorous, healthy grower, carrying the flowers on long, stiff stems. Remarkably free flowering and fine keeping qualities. Price, 15 cents each; twoyear-old plants, 40 cents each.

\section{Paul Neyron}

The flowers are immense! probably the largest and finest Rose; bright, shining pink; clear and beautiful; very double and full; finely scented; blooms the first season and all summer; no collection is complete without this magnificent variety. Price, 1-year, 20 cents; 2-year, 50 cents.

\section{Ulrich Brunner}

A great Rose, known to all planters as one of the best in this class. Immense, large, bold flowers, full and globular; rich, glowing crimson, elegantly flamed with scarlet. Hardy, unusually free bloomer. Highly fragrant. Price, 1-year, 20c; 2-year, 50c. 


\section{LAURENT CARLE}

An extremely vigorous grower of erect branching habit and fine dark green foliage; long buds borne on long stems, opening into large flowers of perfect form, just full enough to open freely; color, brilliant velvety carmine; a very promising variety. Price, 20 cents each; two-year-old plants, 50 cents each.

\section{Miss Mildred Vestal}

This superb new Rose is a result of a cross fertilization between "Rhea Reid," that grand red bedding Rose, and "Richmond," the greatest of all red forcing Roses, which insures in their offspring every point of excellence. It has magnificent large foliage, free from disease of all kinds, and is a tremendous grower-one of the best in all our list. The glory of the plant, however, is in the immense deep double flower of a new and clear shade of crimson scarlet. Prlce, one-year-old plants, 20 cents each; two-year-old plants, 50 cents each.

\section{Marie Delesalle}

As free in growth as Teplitz, flowering continuously; buds long and elegant, opening into lovely blooms of fine form and large petals; color bright deep cerise. A decidedly free bedding Rose Price, one-year-old plants, 15 cents each; two-year-old plants, 40 cents each.

\section{Mad. Melaine Soupert}

The strong vigorous plants form symmetrical bushes, with an abundance of heavy, dark foliage, and the superb, large globular flowers are borne on stiff, erect stems. The form is distinct and elegant, and the fragrance delicious. Color golden yellow suffused with faint shades of pink. Price, one-year-old pot plants, 15 cents each; two-year-old plants, 40 cents each.

\section{Mme. Constant Soupert}

This is one of the most valuable Roses that has been sent out in recent, years. The growth is vigorous and the flowers large and very full, perfect form, color lasting a long time in perfection, citron-yellow shaded with rosy peach; plump, pointed buds of great size. The parentage, Maman Cochet and Marechal Niel, a sufficient guarantee of royal blood. Price, strong pot-grown plants, 15 cents each; two-year. old plants, 40 cents each.

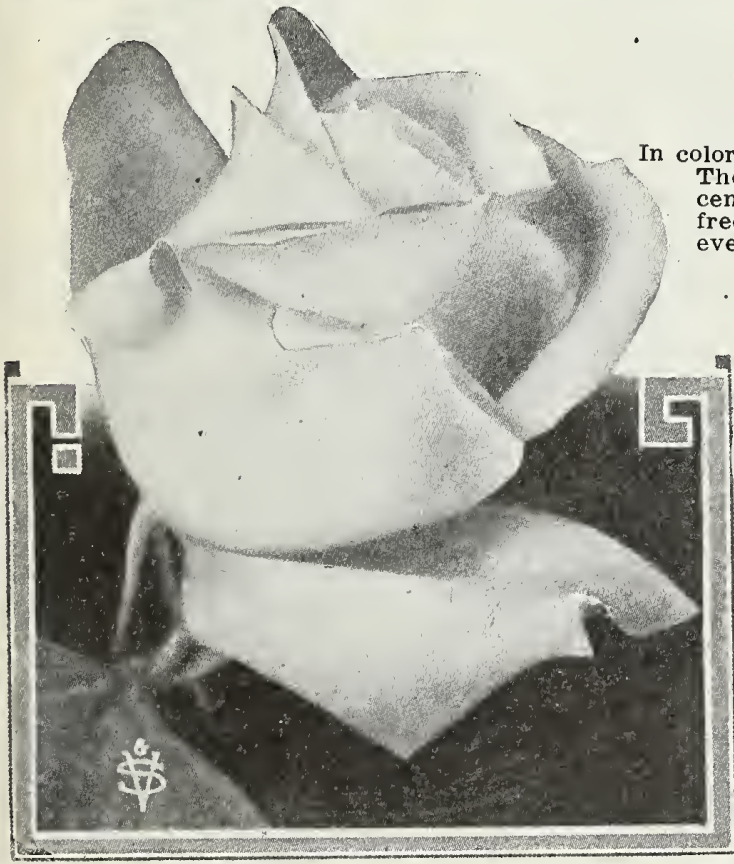

Souv. de Plerre Notting. The apricot-yellow flowers make It a most striking garden Rose; 15 cents.

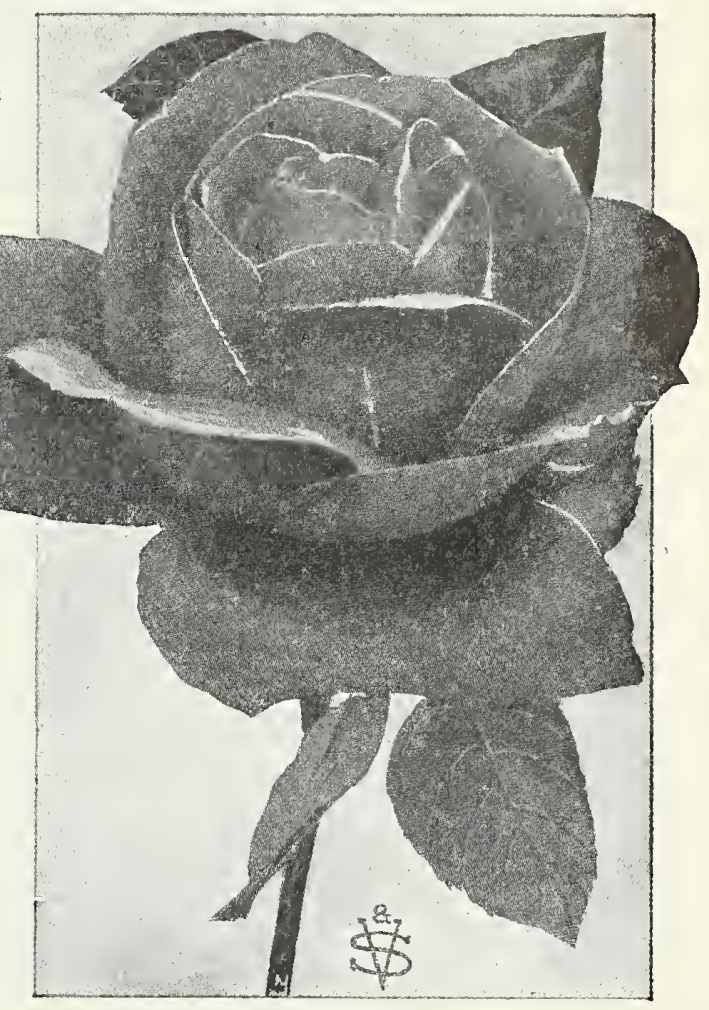

Laurent Carle.

A Varlety for Every Rose Garden.

THE NEW CITRON-YELLOW ROSE

Miss Alice de Rothschild

"Marechal Niel Perfumed, Deliclously Fragrant."

lor a rich, deep citron-yellow, which intensifies as the bloom expands. The flowers are very large, full and of perfect form, with high pointed center; the petals charmingly reflex. Growth is vigorous, erect and free, continuous in blooming, deliciously fragrant; a superb Rose in every respect. 15 cents each; two-year plants, 40 cents each.

\section{Safrano}

Valued very highly for its beautiful buds and handsome flowers. The color is a bright apricot-yellow, passing to orange and fawn, sometimes tinted with rose. A splendid old-time Rose that has never been replaced by any new-comer of its class or color. It is a variety especially adapted to outdoor planting; vigorous, healthy blooms all summer. Price, 10 cents each; two-year-old plants, 40 cents each.

\section{SOUVENIR DE PIERRE NOTTING}

Marvelously beautiful flowers of the Maman Cochet type, very large and well filled, opening beautiful clear apricot-yellow tinged with golden, mixed with orange-yellow, edges of petals shaded carmine-rose. Truly a gorgeous effect. The bush is strong and upright in growth, with heavy canes, and bears a great profusion of these magnificent Roses all summer long. It can always be depended upon for a supply of cut flowers. Price, one-year-old plants 15 cents each; two-year-old plants, 40 cents each.

Dear Sirs: The Roses came in good shape and continue to look fine. Accept thanks for the extra plants, and if you have catalogue on hand, please send me one, and oblige, MRS. J. L. GREENLEE, Gentry, Ark. 


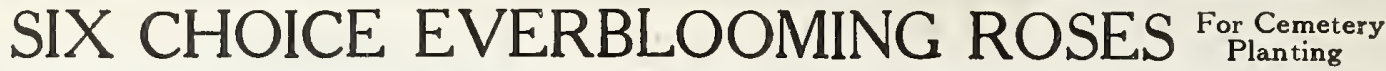

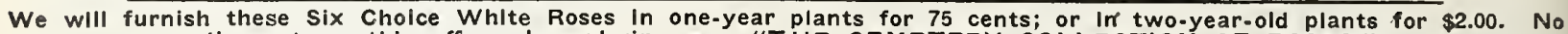
discount on this offer. In ordering say, "THE CEMETERY COLLECTION OF ROSES."

\section{Cornelia Gook}

Very large, pure white buds and flowers. Excellent. Price, 15 cents each; two-year, 40 cents.

\section{The Bride}

An excellent white Rose, and very free flowering. Price, 10 cents each; two-year, 40 cents.

\section{Marie Guillot}

This Rose is as perfect in bud and flower as a Camelia. Pure white in color. Price, 10 cents each; two-year, 40 cents.

largest size, pure white in color. Price, $15 \mathrm{ceach}$; two-year, 40c. CHOICE WHITE ROSES FOR THIS PURPOSE. DO NOT INCLUDE IN CLUB RATES.

\section{Primerose}

A magniflcent bedding Rose coming melon-yellow during the spring and summer, deeper in the autumn, with apricot hadings, a most distinct colorlng, flowers large, of perfect form, long-pointed buds, deliciously scented and very free. Price, one-year, 20 cents; two-year-old, 50 cents.

\section{Duchess of Wellington}

The ground color is chrome-yellow through which run veins of rich orange and shadings of the same running into the rich yellow. Like all high-colored Roses, it varies, but the rule is, that it intensifies rather than lightens in its wonderful shadings. Price, one-year, 15 cents; two-year-old, 40 cents.

\section{Madame Charles Lutaud}

A fine, vigorous grower, with erect branching habit. Stems are almost thornless; foliage broad and nicely bronzed; bud very long and pointed on long stems. The bloom is large and full. Color, rich chrome-yellow, with rosy-scarlet, on the outer petals. Prlce, one-year, 20 cents each; twoyear-oid, 50 cents.

\section{LARGE PURE YELLOW ROSE.}

\section{ALEXANDER HILL GRAY}

The respect of all Rose lovers warrants the lssuing of a champion Rose, and a Tea at that, to pay due homage to one of the world's greatest Tea Rose growers. It is wonderfully floriferous, every shoot being crowned with a flower bud, which develops into a bloom of very large size, great substance and perfect formation with high pointed center from which the petals gracefully reflex. The best and largest pure yellow Tea Rose yet introduced. Its color is a solid, deep throughout Marechal Niel-like lemon-yellow; strongly scented. Price, 15 cents each; large size, 40 cents each.

You Surely Have a Place for Some of the Perfectly Hardy Climbing Roses!

You Can Use Them On PORCHES

ARBORS

ARCHES

PERGOLAS

CLOTHES-POSTS, and

OLD STUMPS OF TREES

Grow them on walls to hide unsightly buildings, on tops of banks to hang over the retaining walls: use them in treeform and have one at every fence-post around your place.

\section{Madame Margottin} favorite. The color of the flowers, which are very fragrant, is dark citron-yellow, with apricot shading and red center; a strong grower and profuse bloomer. Price, one-year-olo plants, 10 cents each; two-year-old plants, 35 cents each.

\section{Tipperary}

Thls Rose makes long, slender, stiff stems in a very short time, many of them to a plant, and every one tipped with a yellow flower. The bud is long and sharply pointed, and opens into a full rosette. Everyone should grow this pretty yellow, for it is a variety that will please. Price, 20 cents each; two. year-old, 50 cents each.

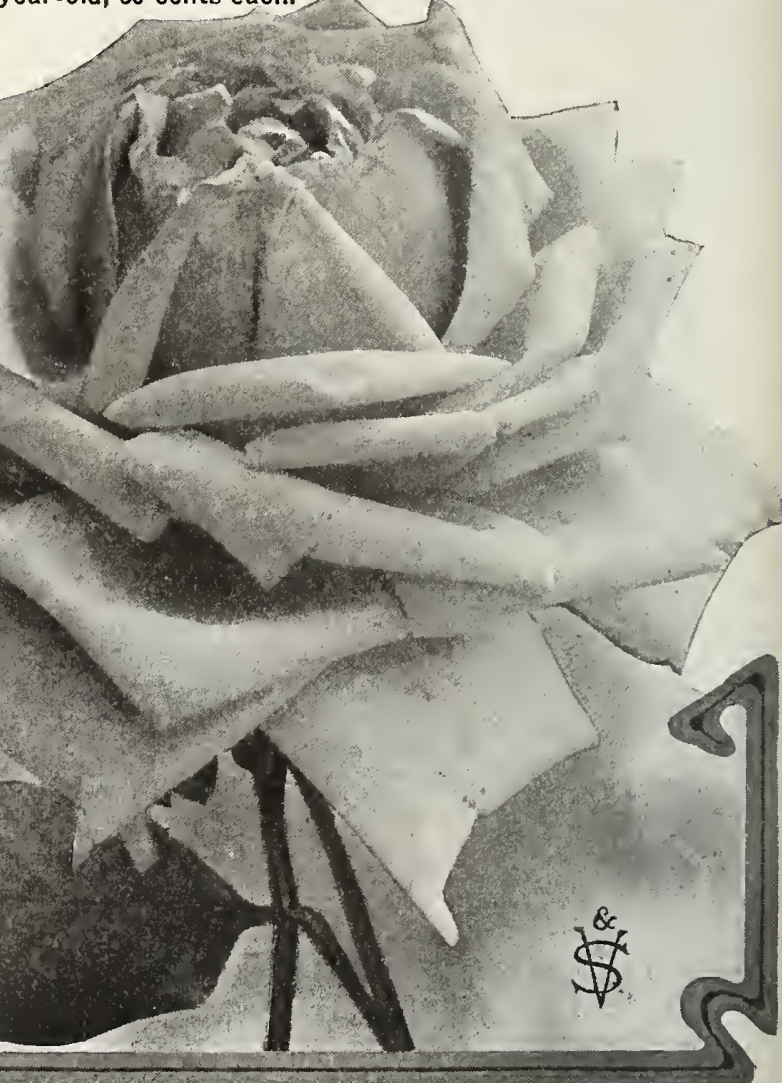

Alexander HIII Gray.

A deep yellow Rose every one can grow. It keeps up a fine successlon of bloom.
This large and perfectly double Rose is considered a great 


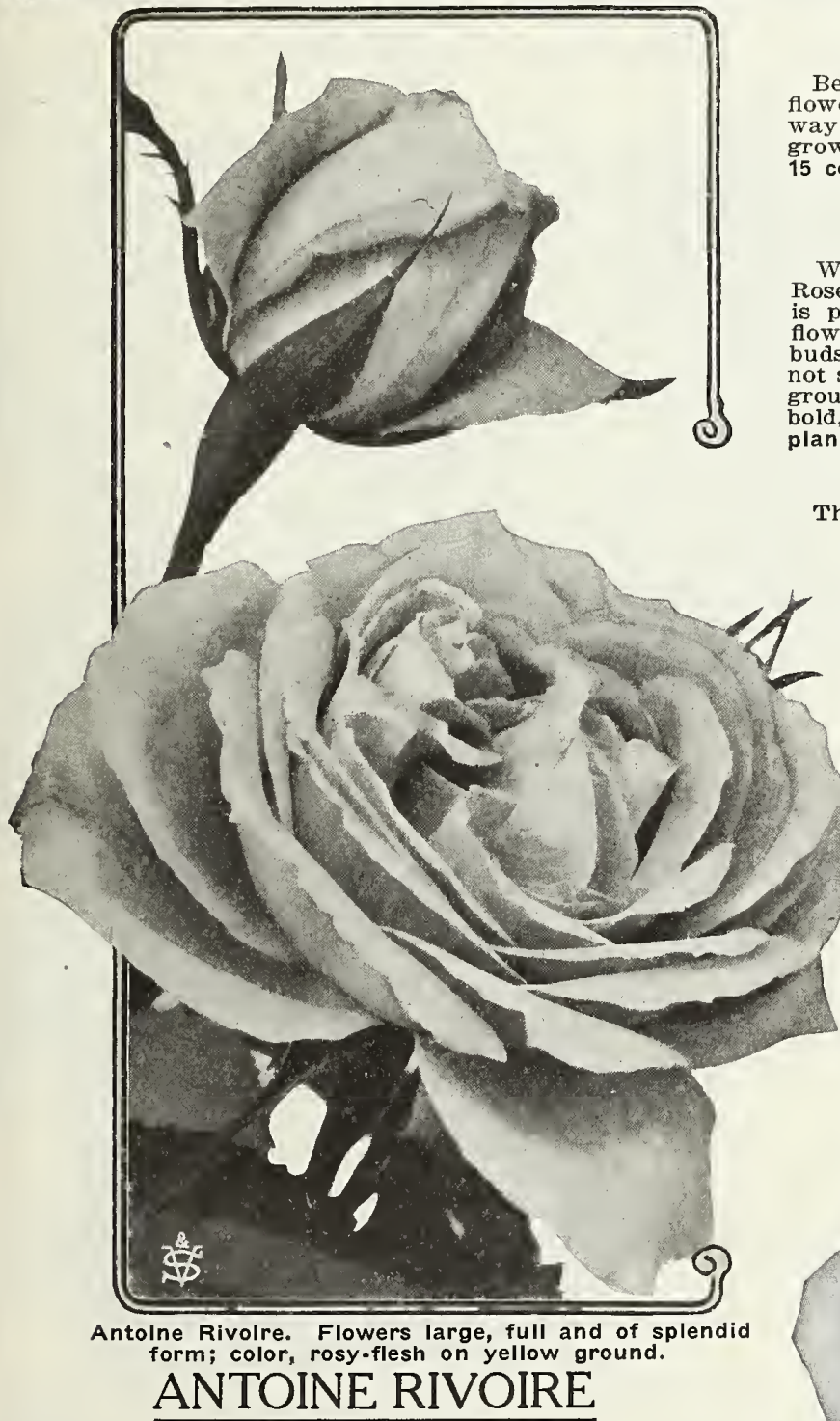

\section{COUNTESS OF GOSSFORD}

Beautiful, clear salmon pink shaded with saffron. The owers are of handsome shape and fine substance. In every it is a remarkably fine, hardy bush Rose which will row to perfection in any garden. Price, one-year-old plants, cents each; two-year-old plants, 40 cents each.

\section{Marie Guillot}

The Queen of White Roses.

We recommend it as one of the most reliable white Tea Roses in cultivation, especially for outdoor culture. The color is pure white, sometimes faintly tinged pale yellow. The flowers are beautifully made, very large, full and double; the buds are very pretty, of sweet fragrance. Anyone who has not seen this splendid variety growing at its best in the open can not conceive of the lovely beauty of its large handsome flowers. Price, 15 cents each; two-year-old lants, 30 cents each.

\section{Etoile De Lyon}

This magnificent Tea Rose is a rich golden yellow; a strong, healthy and vigorous grower, immense bloomer, bearing flowers and buds early and late. The flowers are very deep, rich and full, excellent substance, very sweet. Surely one of the best and most beautiful yellow Tea Roses for general planting ever introduced. Remarkably hardy, both as to heat and cold; frequently standing the winters here uninjured in open ground without protection, and blooming nicely all through the hottest part of the summer. Price, 15 cents each; large two-year-old plants, 30 cents each.

\section{LADY ALICE STANLEY}

"The Most Popular Garden Rose."

This, we predict, will become very popular as a garden Rose. The petals are shell-shaped, forming a perfect flower; the color on outside of petals is a deep coral-rose; inside, delicate flesh, often flushed and suffused with bright flesh. Remarkably attractive, without doubt a magnificent Rose. Price, 20 ce nts: two-year-old plants, 50 cents.

(Summer blooming, hardy with protection). A great favorite in the South: sturdy in growth: branching in habit free flowering as a Geranium; charmingly shaded rosy-flesh color, on yellow ground with a delicate border of carmine; flowers sweetly fragrant. Price, one-year-old plants, 15 cents each; two-year-old plants, 35 cents each.

\section{Admiral Ward}

A splendid crimson-red shaded fiery red; it has large globular flowers with curved petals; its growth is vigorous, of desirable spreading habit, with healthy, attractive bronzygreen foliage. Price, 20 cents each; two-year-old plants, 50 cents each.

Gentlemen: Both orders received in fine condition. The Peach trees were much better than I had expected, and hope to place an order for more next fall. Was afraid to risk them too much this late in the spring. Thanks for extra flowers. My Canna Bed from your 50-cent collection last spring was admired by every one that saw it. Yours truly, MAUDE HARPER, Winnfield, La. 


\section{Everblooming Climbing Roses for the South}

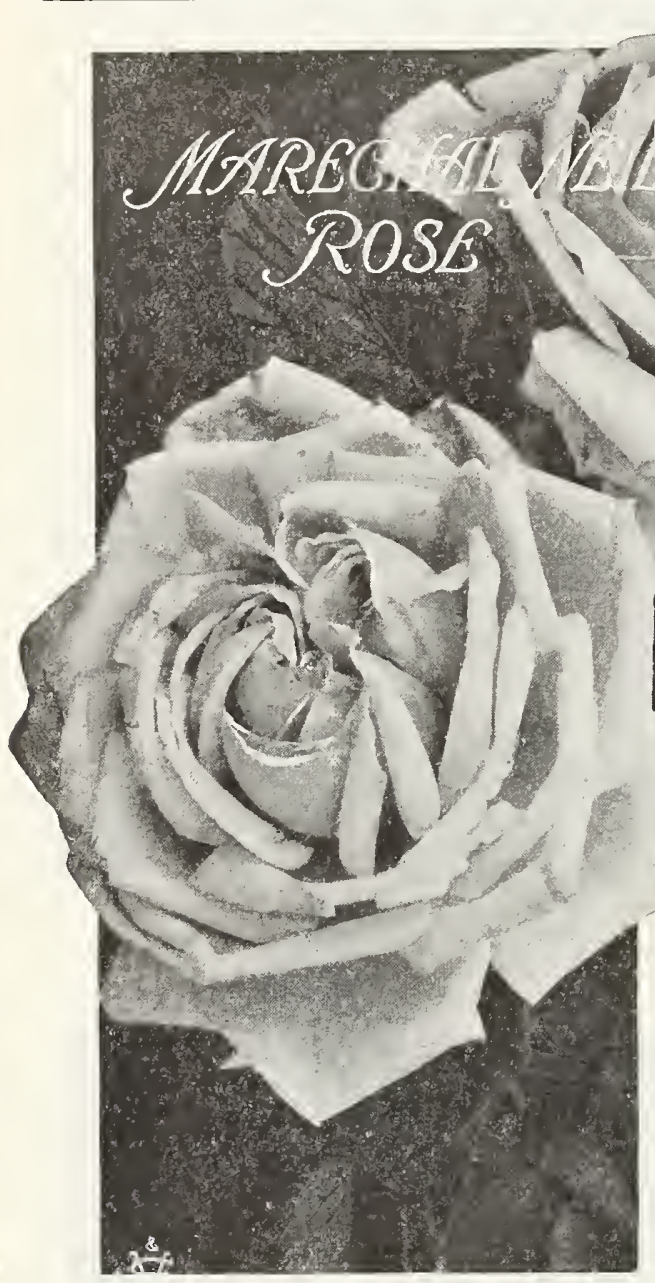

Reine Marie Henriette

A strong growing and climbing Rose, making a grand pillar Rose in the South. Flowers full and well formed: rich, brilliant crimson. A grand Rose and a fine companion to Marechal Niel. Try it. Price, 15 cents each; large size, 35 cents. Climbing Devoniensis

A sport from Devoniensis, from which it differs only in climbing habit of growth. It is fully as productive as the old sort, and being more vigorous, is justly a grand Rose. Color, white, tinged with blush; very sweet. Price, 10 cents each; two-year-old plants, 40 cents each.

\section{Ruth Vestal}

A strong and vigorous grower and true everbloomer. Pure snow white buds, and flowers are of the largest size and perfect form. Exceedingly fragrant. Price, 15 cents each two-year-old plants, 35 cents each.

\section{Gloire de Dijon}

A magnificent Rose; one of the finest in every respect. Large, perfectly double and tea-scented; color rich creamy white, beautifully tinged with amber and pale blush. Price, 20 cents each; two-year-old, 50 cents.
These are the Roses so necessary for the home, giving to it, no matter how humble or pretentious, a touch of beauty not to be had by any other form of adornment. They have also a most useful side, in that they give most delightful and refreshing shade when used on the porch, veranda or pergola. They are used very extensively in covering unsightly spots in the grounds, for screening outbuildings and for trailing down over embankments.

\section{MARECHAL NIEL}

)

The Famous Rose.

The fame of the superb yellow Rose Marechal Niel, with its large, deep, golden-yellow flowers, is world-wide. It is almost universally held to be the finest Rose for indoors or outdoors, where the climate admits of its cultivation. Its magnificent golden-yellow flowers are almost massive in dimensions, and reports from growers tell of single plants showing one to two thousand blooms at a time. It is of strong growth and beautiful foliage. It is grand in petal. shape, color, fragrance, lasting qualities and size, an extremely free bloomer and flowers throughout the season. Contrary to many Roses, which lose their color after opening. Marechal Niel decidedly improves and takes a deeper yellow after being kept for a day or two. The tea fragrance is strongly present in this Rose. It is a variety which practically stands by itself. Price, 15 cents each; stronger plants, 25 cents; two-year-old plants, 50 and

\section{Climbing White Maman Cochet}

The Sensational, New, Hardy, Everblooming, White Climbing Rose, Long Sought For.

Just as the old favorite White Cochet is one of the very best of all Thite Tea Roses, so we believe this new White Climbing Tea will jump the plant grows wondrous strength and vigor. This is without doubt one of the appeals strongly to those who like to have something different from their ants, 50 cents each.

\section{Gainesborough}

For a hardy everblooming climbat beauty. ve place this variety at the head of the Hybrid Teas. Its delicate colors to describe, being delicately tinted flesh, almost white, and lustrous When in full bloom it resembles a large, fine, white, fluffy Peony, Wuggestion of stiffness, often measuring eight to nine inches in diameter. Be sure and try this grand Rose; you will meet with no disClimbing Queen's Scarlet

Climbing China. A genuine Queen's Scarlet with a vigorous climbing habit; wili make a fine Rose. Color, velvety crimson. Price, 15 cents each; two-year-old plants, 50 cents each. Climbing Richmond

The beautiful, hardy, everblooming Pillar Rose. A fine, handsome bush, 3 to 6 feet high, with glossy foliage, and blooms constantly from early June till freezing weather. One of the most beautiful. Pure, rich velvety red, fully equal to General Jacqueminot in color and equally large and beautiful. Price, 20 cents each; two-year-old plants, 50 cents each.

\section{Lamarque}

A fine climber for greenhouse and conservatories; pale canary yellow, almost white; beautiful buds; large, full flowers, very double and sweet. Price, $\cdot 15$ cents each; large plants, 30 cents each.

\section{W. Allen Richardson}

The coloring of this Rose is simply exquisite. The base and back of petals are a bright yellow, the center highly colored with glowing copper and rose; first class climber. We highly recommend it. Price, 10 cents each; large plants, 30 cents each. 


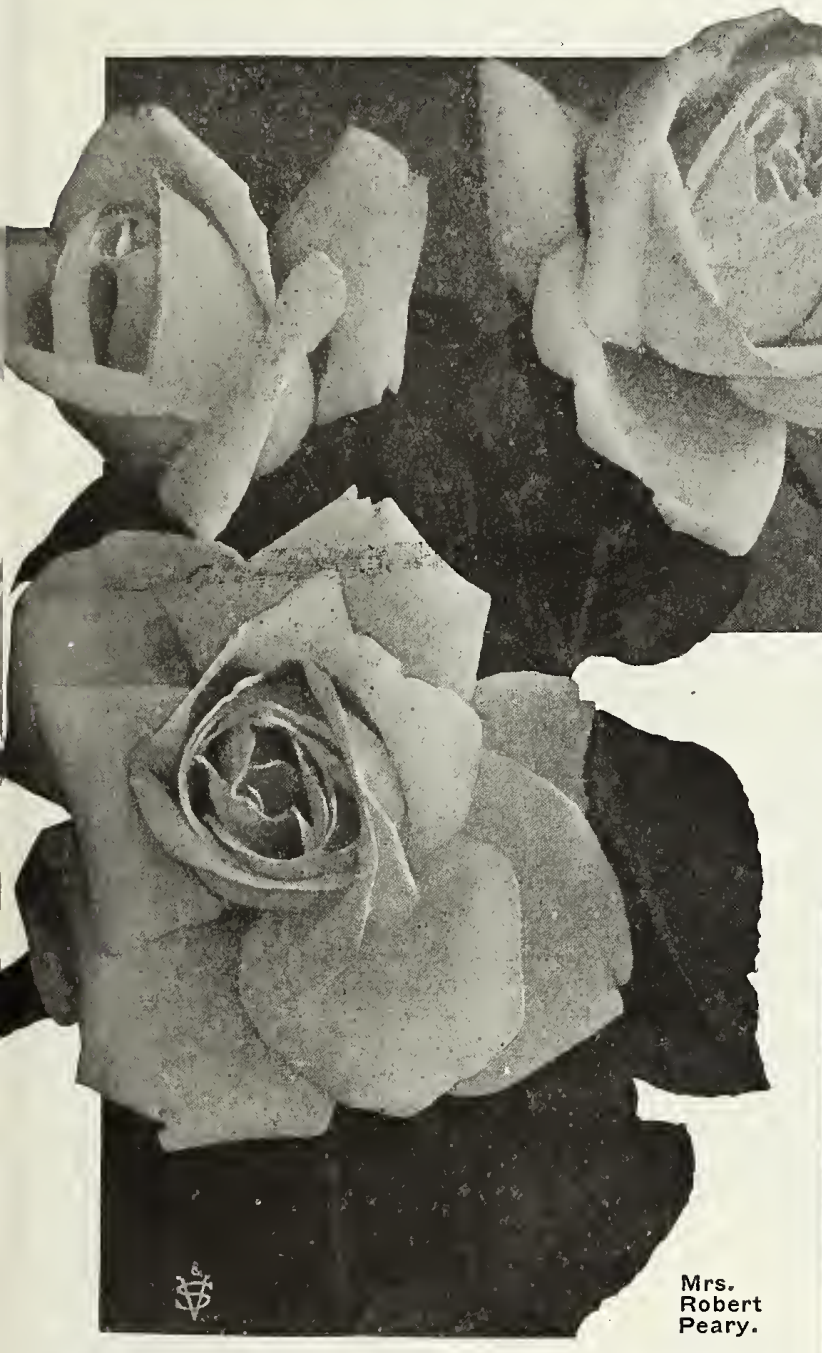

\section{Special Offer of Climbing Roses} WHEN SELECTION IS LEFT TO US

We will choose for you same as if for a personal friend, for we feel the responsibility of giving you good varieties and also first-class, healthy plants that will be sure to bloom. Mention the colors, and the quantity of each color you prefer, to enable us to select to your satisfaction.

PRICES: TEA ROSES (OUR SELECTION) 1-year size 2-year size............................................... $\$ 3$, by express

Dear Sirs: The Trial Collection of Roses were fine and I was more than pleased with them, and they all came in fine shape. Thanking you for your promptness in filling my order, I remain, Very truly yours, MRS. JAS. R. HAUPE, Lenapah, Okla.
A Great, White, Hardy, Everblooming Climbing Rose (or Climbing Kaiserin Augusta Victoria.)

The first white hardy everblooming climbing Rose. It is an offspring of that grand variety, the best pure white hardy everblooming Rose, Kaiserin Augusta Victoria. The flowers are something grand; they are the equal of the finest and most beautiful cut flower Roses; of splendid substance; extra large, full, deep and double, and are produced on long, stiff stems. Buds are long and pointed. In bud and flower it is truly beautiful; has a delicious fragrance-just like cherry blossoms. If you want a quick growing, hardy climber, sure-to-bloom Rose, one that will give you flowers this season, this is the only white variety that will do it. Price, 15 cents each; large size, 40 cents each.

\section{Climbing Wootton}

To our mind this great Rose is to be classed with Mrs. Robert Peary and other great climbing varieties for these reasons: It is perfectly hardy, has no weak spots, grows with wonderful vigor, blooms continuously throughout the growing season, produces flowers that are nothing less than superb, both in beauty and in fragrance. If there is such a thing as having one Rose more beautiful than another, we think this variety may be entitled to this distinction. It is a strong, rampant climber, growing in one season to a height of from ten to fifteen feet, with large, heavy, insectproof foliage. It produces in most wonderful profusion its superbly-formed flowers, which are bright magenta-red, passing to violet crimson, richly shaded. The flowers are large, full and regular, with thick, leathery petals, and deliciously scented. Make beautiful buds. Price, 15 cents each; large size, 40 cents each.

\section{Climbing Clothilde Soupert}

\section{Hardy, Everblooming Climbing Rose.}

Quick and abundant bloomer and healthy, vigorous growth The flowers are two and one-half to three inches across, and perfectly double, rich creamy-white, sometimes tinted with blush and borne in immense profusion, the whole growing season from June to November; handsome, glossy green foliage, not subject to insects or disease. Price, 15 cents each; two-year-old plants, 35 cents each.

\section{Climbing Meteor}

A superb everblooming climbing Rose. A sport from Meteor, famous for its magnificent flowers. True climbing habit, attaining a height of 10 to 15 feet in a single season. Free, persistent bloomer, with magnificently formed buds and flowers. Dark, velvety crimson, the equal of any Rose in cultivation. Hardy, with protection and will give absolute satisfaction. Price, 15 cents each; two-year-old plants, 40 cents each.

\section{Climbing Gruss an Teplitz}

A climbing form of Gruss an Teplitz. Unquestionably one of the finest climbing Roses ever introduced. The color when first opening is very dark rich crimson, quickly changing to bright scarlet, shading to velvety fiery red. The flowers are very showy and handsome. Remarkably healthy and vigorous; almost immune from all diseases. Price, one-year-old plants, 15 cents each; two-year-old plants, 40 cents each.

IN BUYING ROSES buy them as you would anything else-keeping in mind that the cheapest is often the dearest in the long run. Cheap Roses must necessarily be grown cheaply, therefore buy where you know you are safe, both as regards prices and quality. Our stock for this season's trade was never in better condition or larger supply. 


\section{FREE-FLOWERING HARDY CLIMBERS}

Large-FlowerIng Types.

\section{CLIMBING AMERICAN BEAUTY}

Here we have the latest triumph in American Rose growing, the true Climbing American Beauty in all its promise and glory, the realized dream of every Rose grower. Just the same as American Beauty practically. Large flowers, each produced on separate stems, vivid rosy-crimson in color, with delicious fragrance. Borne in the greatest profusion throughout the growing season. Foliage tough and leathery, deep, glossy green, sun and insect proof. The youngest plants attain a height of 10 to 15 feet in a single season. Hardy and as sturdy as an oak in all localities. Splendid in the South. For single specimens, trailing over verandas, for trellises, anywhere and everywhere, this Rose will give the greatest satisfaction. Words of description can hardly do justice to this magnificent Rose. Absolutely true to name, on its own roots. Strong one-year-old plants, 15 cents each; two-year-old plants, 50 cents each.

\section{Dr. W. Van Fleet}

Dr. W. Van Fleet bears flowers which, when open, run four inches and over in diameter. The center is built high, petals beautifully undulated and cupped. The color is a remarkably delicate shade of flesh pink on the outer surface, deepening to rosy flesh in the center. The flowers are full and double, of delicate perfume, buds pointed, stems twelve to eighteen inches, and fine for cutting. The foliage is a peculiar shade of bronze green, large and glossy, with spines a bright bronze red. The variety is a vigorous grower, immune from mildew. Price, oneyear-old plants, 20 cents each; two-year-old plants, 50 cents each.

\section{Tausendschon or Thousand Beauties} A Grand Hardy Climbing Rose.

A beautiful, new climbing Rose which has leaped into popularity by its inherent merit and beauty. The name "Thousand Beauties" is very appropriate and refers particularly to the wonderful variety of colorings found on any one plant. The flowers are soft pink at first, but as they age the most beautiful shades of carmine-rose, cerise, blush and soft white with a gleam of light yellow, soft crimson and intermediate tints; a combination of charming coloring, which is bewildering. Price, 15 cents each; two-year-old plants, 50 cents each.

\section{American Pillar}

The Flowers are single, of immense size, three and four inches across and very durable. They hang in immense clusters all along the branches and make a remarkable sight, a veritable sheet of bloom. The color is a dainty apple-blossom pink, while in the center of each flower is a cluster of bright yellow stamens. This Rose is as hardy as an oak tree, of very strong growth, soon covering any space allotted to it. Price, one-year-old plants, 20 cents each; two-year-old plants, 50 cents each.

\section{Silver Moon}

The flowers run four and one-half inches and over in diameter, clear silver white in color, petals of great substance and beautifully cupped. The center is filled with bright yellow stamens, a very attractive feature. It is very floriferous, the plants literally covering themselves with great Clematislike flowers. They are borne on strong stems, twelve to eighteen inches long, and are delicately fragrant. The foliage is large and abundant, bronzygreen, glossy and practically immune from mildew. Price, 20 cents each; two-year-old plants, 50 cents each.

\section{THE FAMOUS DOROTHY PERKINS ROSES}

DOROTHY PERKINS. Beautiful shell-pink color, which holds for a long time, fading finally to a lovely deep rose; very sweet-scented; fully equal to Crimson Rambler in foliage, hardiness, habit of growth and blooming qualities.

EXCELSA. (Red Dorothy Perkins). A radiant bloodred cluster Rose, as free and double as Dorothy Perkins, of which it is the red prototype. The clusters are very large. Price of all Perkins Roses, one-year-old Plants,
WHITE DOROTHY. A fine, hardy climber of Dorothy Perkins type. We believe it is a better Rose in many respects than that variety. It bears double pure white flowers in immense panicles. By far the best white hardy Rose yet sent out

DOROTHY DENNISON. (The Blush Dorothy Perkins.) Flowers of a delicate cherry pink color, which fades to a soft white; deep green foliage Vigorous grower, perfectly hardy. Will cover a large porch or trellis in an incredibly short time. One of the most charming of ail climbers. 15 cents each; two-year-old plants, 35 cents each. 


\section{Any 12 Roses---A Complete Rose Garden---for $\$ 1.00$}

It does not follow that because the following Hardy Tea Roses for the home garden are relegated merely to a line of description that they are in any way inferior to others given more extended notice. These are the tried and true favorites, so well known and beloved of all who cherish Roses-and that means everybody. The limitations of this book will not permit us to extol their virtues, as they deserve, for many are worthy of a full page of description.

AGRIPPINA. Free bloomer; color, bright red.

BOUGERE. Peach-pink, delicately shaded with lilac; deep, full and double.

CHAMPION OF THE WORLD. Lovely, clear, deep pink. Large and double. One of the best of all Roses for outdoor cultivation.

C O UNTES S ANNA THUN. It is of immense size and of the most lovely and perfect form imaginable. Color a beautiful citron yellow, with coppery and peach center, shading to orange salmon and silvery pink.

DUCHESS DE BRABANT. A bright China Rose, with coppery yellow center, ends of petals suffused with carmine.

DEVONIENSIS. Creamy white with rosy center; large and full.

EUGENE MUNCHEN. Buds long and pointed, opening up into large, full flowers. Color silvery lilac-rose, graduating into amber-white at the base of the petals. An excellent outdoor Rose.

HERMOSA. An old favorite. It is always in bloom, and always beautiful. The flowers are cupped, finely formed and full. Color the most pleasing shade of pink; soft, but deep.

MLLE. JEAN DUPUY. Flowers large and full, of gorgeous coloring, salmon, shaded bright rose, with touches of yellow.

MADAME SCHWALLER. Large, globular flowers; color transparent salmon-rose; petals finely edged with violet-carmine; highly perfumed.

Price of all Roses named on this page, 10 cents each, and 12 for $\$ 1.00$, postpaid; two-year-old plants at 30 cents each, $\$ 3.00$ per dozen, purchaser's selection; our selection, 25 cents each, $\$ 2.50$ per dozen, by express.

\section{"Great Trial Collection Of Vestal Roses"}

\section{SIXTEEN SUPERB HARDY EVERBLOOMING VARIETIES SENT POSTPAID FOR \$1.00.} All Magnificent Plants. Sure to Bloom the First Year. A trial will convince you. Think of the pleasure from such a

Our great stock of Roses contains many very fine varieties which our catalogue does not, describe in detail, every way the equal, if not the superior, to the popular favorites.

Amongst these Roses are some of the finest ever grown by anybody anywhere; Roses that combine such beauty of form, richness of color, freedom of bloom and hardiness and health as to make them the equals, if not the superiors, of many popular favorites.

We want you to know these Roses as we do, hence we malke this remarkable offer. If you will send us $\$ 1$ we will forward sixteen of them, all different kinds, no two alike, properly labeled, postpaid, and safe arrival guaranteed. Yo's will not be disappointed in these Roses-take our word for it. They will bloom this year throughout the season, and will continue each succeeding year to bloom more profusely, and be a source of joy forever.

This offer Is only made to induce you to give us a trial, and it will be to our interest to send only a fine assortment of good Roses, well rooted, that are sure to bloom freely the first year. 

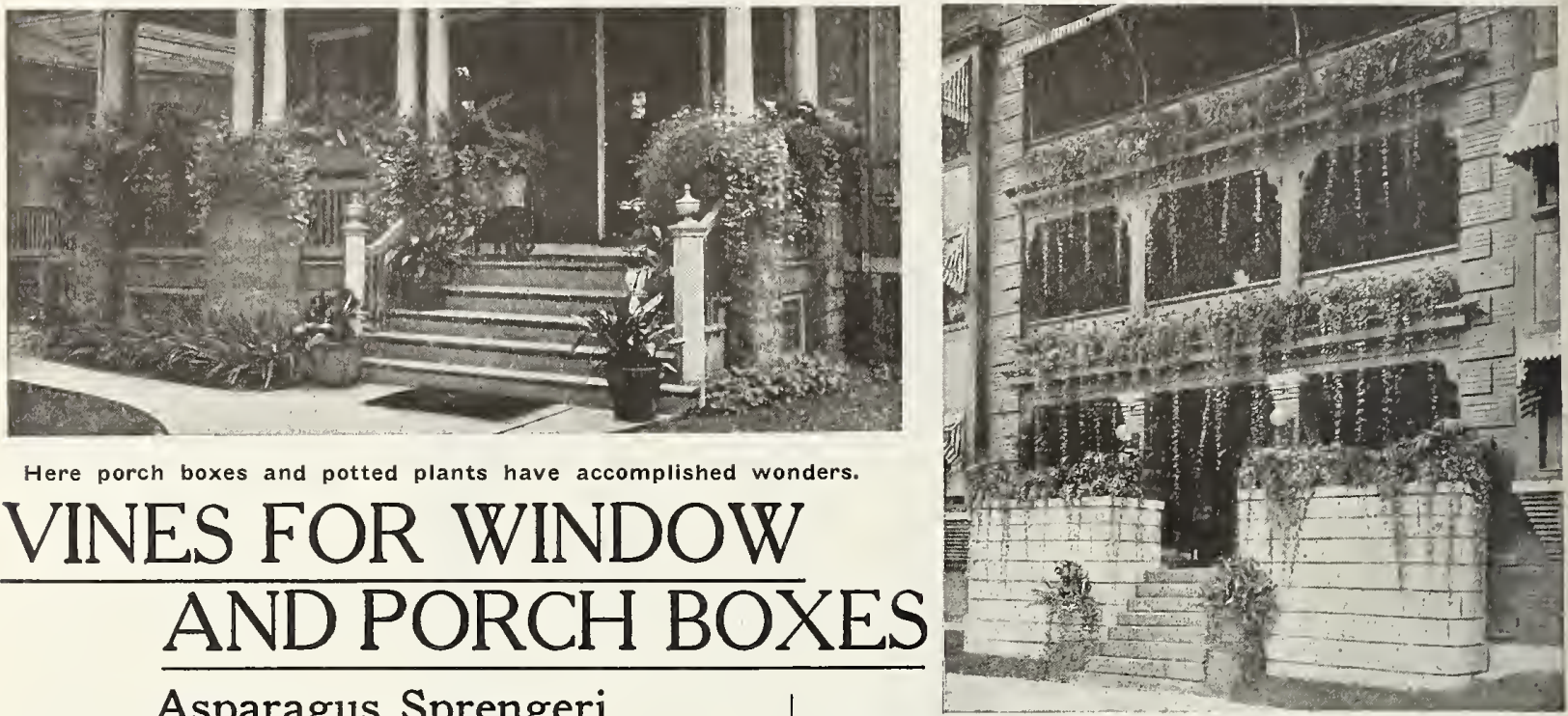

Here porch boxes and potted plants have accomplished wonders.

\section{VINES FOR WINDOW AND PORCH BOXES}

\section{Asparagus Sprengeri \\ (Trailing Basket Fern.)}

Not only is useful for cutting in sprays, but grown in suspended roots it makes one of the prettiest house plants we have. Price, 10 to 20 cents each; $\$ 1.00$ to $\$ 2.00$ per dozen.

\section{Glechoma}

(Variegated Ground Ivy). The foliage is a bright green, marked with pure white and has a refreshing fragrance similar to mint. Graceful and beautiful for hanging baskets. A general favorite with all of our customers, as there is a continued steady demand for it. Enţirely hardy when planted out, and makes an ornamental, dense mat on the ground. Each, 10 cents; dozen, $\$ 1.00$.

\section{Parrot's Feather}

An aquatic hanging plant is a novelty indeed, and we have it to perfection in this dainty little jewel. Its long, trailing stems are clothed with whorls of the most exquisite foliage as finely cut as the cypress vine and much more delicate. Planted in a watertight hanging basket, so water may be kept standing on the surface, it will trail finely. Price, 10 cents each.
This shows how flowers will do "down town" where they do not get much sun.

\section{Anthericum}

comosum. A pretty variegated plant well adapted for use in hanging baskets, or as an edging for porch or window boxes, with graceful, 4 to 6 inch long, deep green foliage with a band of creamy yellow through the center. Price $20 \mathrm{c}$ each.

\section{Coleus}

TRAILING QUEEN: Elegant fringed leaves blending from pink to crimson, finely scalloped edges. The plant is half trailing or running and is well adapted for window boxes, baskets or vases. Price, 10 cents each; per dozen, $\$ 1.00$

YELLOW TRAILING QUEEN. A center wedge of creamy white bordered green; the whole margined yellow. Price, 10 cents each; per dozen, $\$ 1.00$.

\section{Vinca}

VARIEGATED LEAVES. An elegant low growing, climbing vine; bright, glossy green leaves, widely bor-
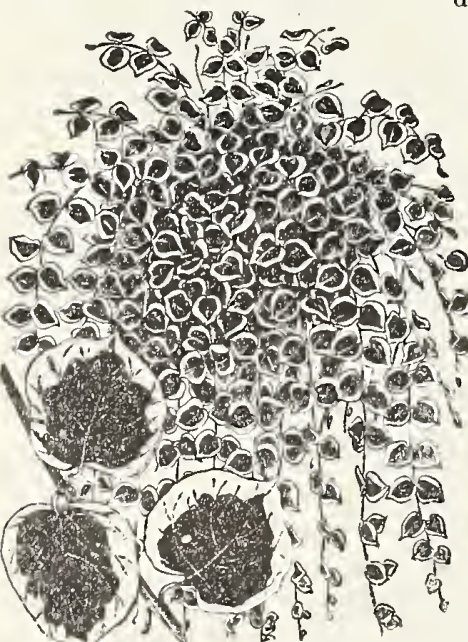

Vinca Major Veriegata.

\section{dered with creamy white; extra nice for pots, vases.}

baskets, window boxes ad rockeries; good everywhere;

always wanted. Price, 10 cents each; six for 50 cents; twelve for $\$ 1.00$.

HARRISONI. A variety of strong growth: margin of leaves rich, dark green, central portion light green, furnishing an abundance of star shaped, light blue flowers. Price, plants suitable for hanging baskets, 15 cents each; extra large, 25 cents each.

\section{Ivies}

ENGLISH. An old favorite vine, showy the year round if properly grown. Hardy in the South. Each, 5 cents; large, 25 cents.

KENILWORTH. An old favorite trailing Ivy. Perhaps the best for shaded places or rooms where light is not strong. Each, 10 cents; dozen, 75 cents.

GERMAN or PARLOR IVY. Well known Ivy which is very popular as a plant for hanging baskets and vases. Can be grown with very little trouble. Each, 10 cents; dozen, 75 cents.

\section{Russelia Elegantissima}

Especially adapted for hanging baskets, vases or window boxes. The plant is literally covered with brilliant coral-red flowers. Well grown plants, 3 to 4 feet in diameter, look like a shower of delicate coral blossoms. Price, 10 cents each; three for 25 cents.

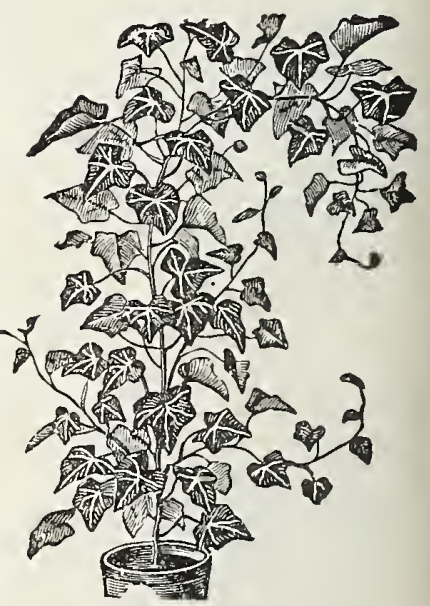

Engllsh Ivy. 


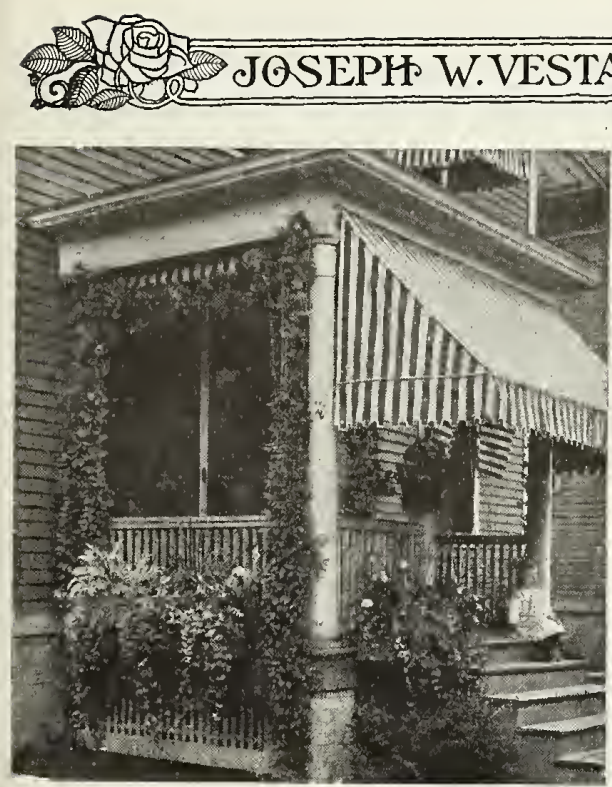

Porch boxes are wonderfully decoratlvecost but little.

THE SUNNY SIDE PORCH BOX COLLECTION, \$2.50. A selection of plants suitable for sunny locations.

4 Geraniums. Bright colors.

4 Petunias. All different.

2 Lantanas. Upright and trailing.

2 Coleus. Upright and weeping.

3 Vinca. Variegated.

2 Salvia. Scarlet.

2 Marguerites. Single white.

2 Verbenas. Red and pink.

2 Nasturtiums.

2 Wandering Jew.

SPECIAL.-One-half of above collection, same assortment but one-half the number of each kind, enough for a box three feet long, for $\$ 1.25$.

\section{Miscellaneous Plants for}

GERANIUMS. Double and Single and ivy Leafed. For adding color to a porch box or hanging basket, nothing is so effective as bright red Geraniums. We can supply them in two sizes. 20 cents each; $\$ 2.00$ per dozen.

FERNS. For shady porches. Ferns are an absolute necessity, they grow and thrive where blooming plants would be a failure. We recommend Boston, Scottii, Whitmanii and Cordata. Price, 15 cents each; 4 for 50 cents.

VERBENAS. For sunny situations Verbenas will be found well adapted for boxes and vases. Prlce, 10 cents each; $\$ 1.00$ per dozen.

SINGLE PETUNIAS. For a cheerful and charming array of color, the small flowered single Petunias can not be surpassed. You can have the seed at 10 cents per packet, or the plants well along to their blooming size at 5 cents each or 50 cents per dozen.

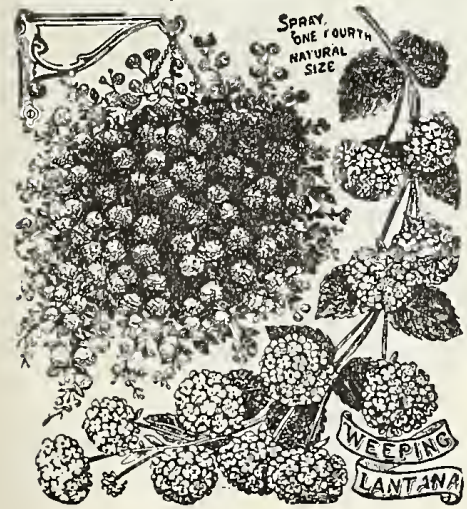

MONEYWORT. A beautiful trailing vine with small green leaves, suitable for hanging baskets, vases or covering graves. Price, 5 cents each; 6 for 25 cents.

SAXIFRAGA SARMENTOSA (Strawberry Gera. nium). A plant of low habit. Leaves nearly round, and striped freely with silvery bands. Blooms white, of a great beauty, and borne in spikes nearly twelve inches high. Adapted for hanging baskets, vases, etc This is also known as Strawberry Geranium. Price, 10 cents; 3 for 25 cents.

WANDERING JEW (Tradescantia Multicolor). Most beautifully variegated purple, scarlet and white. Price, 10 cents each; $\$ 1.00$ per dozen.

THUNBERGIA (Blackeyed Susan). Beautiful, rapid-growing climbers, thriving in a light rich soil in warm situations. Flowers white, cream, yellow and orange, with a heavily marked deep black eye. Price, 5c.
THE SHADY SIDE PORCH BOX COLLECTION, \$2.50. 2 Asparagus, Plumosa and Sprengerii.

3 Variegated Ground Ivy.

6 Ferns. Boston and Ostrich Plume.

Acalpho

2 Pllea, or Artillery Plant.

4 Coleus. Upright and trailing.

1 Russellia. Fountain Plant.

SPECIAL.-One-half of above collection, same assortment but one-half the number of each kind, $\$ 1.25$. $\left\{\begin{array}{l}\text { NOTE. - This } \\ \text { collection con- } \\ \text { t a ins enough } \\ \text { plants for a six- } \\ \text { foot box. }\end{array}\right.$

\section{(n)}




\section{Miscellaneous Bedding Plants and Bulbs}

\section{Acalphas}

Brighter and More Attractive Than Coleus.

AUTUMN TINTS. (Acalpha Blcolor). A most wonderful plant, surpassing the finest Coleus or Begonia in the rlch color of the leaves, which are beautifully marked wlth brlght green color margined with a wide irregular band of lemon. yellow and having wide yellow bars running lengthwise of the leaf, and also thickly dotted with yellow blotches. Its most important feature is its wonderful qualification for bedding, as it will stand bedding out like a Coleus; in fact, in the sunniest place it produces the highest coloring. Price, 15 cents each; 2 for 25 cents.

FIRE DRAGON. (Acalpha Trlcolor). Rich and beautiful. Mottled and blotched with crimson and carlet on green background. Foliage extra large and maintains its marking regardless of summer heat. Price, 15 cents each; 2 for 25 cents.

A. MARGINATA. The largest sort in the genus, growing in open ground up to 8 feet high. Fast growing. Leaves green, margined with varying shades of red, pink and cream. In cool weather is exceptionally gorgeous. 15 cents.

A. MILTONIANA. Of medium growth, with nar row, cut leaves, green and cream-colored. cents each; 3 for 40 cents.

\section{Aloysia \\ Citriodora}

\section{(Lemon Verbena.)}

The delightful fragrance of its leaves renders it indispensable in making bouquets. Price, 10 cents each.

\section{Alyssum}

LITTLE GIANT. A great improvement on the old double Sweet Alys wum, it belng of a more dwarf compact habit, with flowers twice as large Price, 5 cents each; 50 cents per dozen.

\section{Crinums}

FIMBRIATUM. Also called Angel Lily and Milk and Wine Lily. In this, the flower is a pure white with a streak of pink down the center of each petal. It is delightfully fragrant and blooms all summer. Prlce, large bulbs, 35 cents each.

KIRKII. Called Lily of the Orinoco. Plant same size as Kunthianum. Flower opens wide till it is 6 to 7 inches across. Its color is a glistening white with wide strips of deep carmine down each petal. The texture of petals is thick, crisp and luscious. It keeps opening blossoms for ten days and when well established, will have two or three otalks of blossoms a season. Prlce, large bulbs, 50c each.

KUNTHIANUM. Called Confederate Lily. A larger plant than preceding, as leaves often grow 4 inches broad and 4 feet long. The flower stalk rises 2 1-2 to 3 feet high, and is crowned with an umbel of 15 to 25 buds, of which there are from 3 to 6 in bloom all the time, and the cluster lasts a week or ten days. The flowers are trumpet shaped hanging down in a lovely cluster; each flower is about 10 inches long and opens 3 or 4 inches. Its color is a soft, white-striped on outside with a dull, but rich, deep rose, fading inside into the loveliest sea-shell pink. Prlce, large bulbs, 35 cents each.

\section{Achyranthus}

Ranks with Coleus as a bedder, but more hardy. Retains its brilliant coloring all the season. Price, 5 cents each; 25 for $\$ 1.00$.

BRILLIANTISSIMA. Leaves and stems of a beautiful ruby red. Splendid for bedding.

McNALLY. Golden yellow, veined green.

\section{Alternantheras}

Or Dwarf Coleus.

Price, 5 cents each; 50 cents per doz.; $\$ 3.00$ per 100.

AUREA NANA. It is admirably adapted for ribbon lines, carpet bedding, or massing front lines in foliage beds. It is of compact growth. Color of foliage, bright golden yellow.

BRILLIANAISSIMA. Crimson, scarlet and pink. Its gorgeous color gives it the name of Rainbow Plant."

PARYONCHOIODES MA. JOR. It is the Alternanthera so largely used in all ornamental carpet gardening. It grows only about six inches high, and can be kept much shorter by shearing it. The color is as bright when first planted as at any other time, and this is kept constantly. The color is brightest carmine,

\section{Amaryllis Johnsonii}

One of the most gorgeous bulbous plants grown. We have seen specimens of a few years' growth that completely filled a window. Nothing is more showy than this grand plant during late winter or early spring, bearing large flowers of intense crimson with a delicate white feather in each petal. Price, extra large bulbs, 50 cents each.

AMARYLLIS VITATTA. These are the finest of all Amaryllis, taking their place beside the Auratum Lily and some tropical orchids. The flower has six lovely petals of thick, crisp, velvety texture, they are rounded, wide and open wide, till the finest flowers are eight and ten inches across. The petals do not curve tightly back as in the Auratum Lily, nor remain nearly closed as in the trumpet of the Easter Lily, but just open wide. The colors are red and white, and the reds vary from a deep vivid, glowing crimson, the color of arterial blood, up through fiery scarlets which burn resplendent to an almost true orange, the color of light and passion combined, then with less yellow and fainter, they shade into lovely pinks. Price, large bulbs, 50 cents each.

AMARYLLIS FORMÓsISSIMA (Jacobean Llly). Gorgeous flowers of dark velvety scarlet, shading to maroon and having a satiny-white stripe in the center of each petal. Plant in sand and pebbles covered with water, or in soil. 25 cents each.

AMARYLLIS HALLII. Delicate lilac-pink, shaded with clear blue. The foliage dies down in July, after which the masses of blooms spring up as if by magic. 30 cents each. 


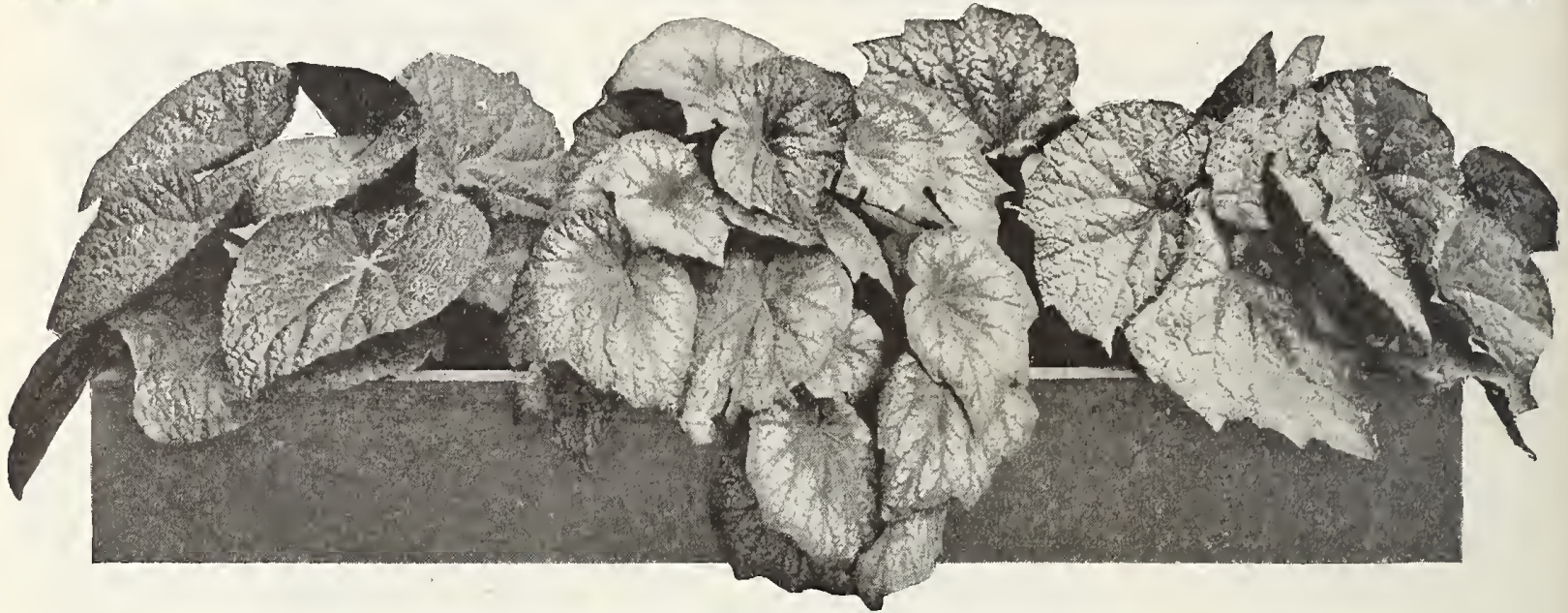

\section{Mammoth Leaved Rex Begonias}

"The Most Decorative of the Begonia Family."

The Rex division of the Begonia family has been a great favorite. In no other class of plants do we find the rich metallic coliage, lustre and various colors so satisfactrily blended as here. We find colors of bright green, silver colored, reddish bronze, as well as varieties of bright rosy plum color. The plants are grown exclusively for the great beauty of their foliage, as they make unexcelled pot plants. The Rex Begonia dislikes our dry atmosphere and bright sunshine, and thrives best in a rather shady and moist situation. The soil should be as near as possible of the nature of a mixture of loam, sharp sand, and well rotted cow manure. The soil should be light and porous. Price of Rex Begonia, good, strong established plants, 30 cents each; 2 different varieties for 50 cents; 5 for $\$ 1.00$.

\section{Beefsteak Begonia}

Sometimes called the

"Strawberry L e a f" Geraniúm; very orna. mental; leaves silver top, red und e $r$ n e a $t h$; $\mathrm{v}$ e $r \mathrm{y}$ pretty flowers. Each, 20 cents; 3 for 50 cents.

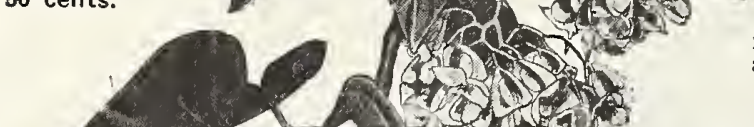

A superb new variety of the Coral Begonia, producing gigantic trusses of Beg. Coralline Lucerne

ronzy red flowers and flowering continuously from April to November. The foliage is dotted with silvery white. Blooms last from a month to six weeks, and are borne in immense clusters, almost hiding the plant. The color is bright coral-red, changing to a delicate pink. Nice plants, 25 cents; 3 for 60 cents.

\section{Pilea Arborea (Artillery Plant.)}

A pretty little plant of drooping, graceful habit and fern-like foliage, literally covered with small, pretty flowers, giving the plant a pleasing effect; fine for basket or pot plants. Price, 10 cents each.

\section{Manettia Bicolor}

The most beautiful and desirable of all vines. Can be grown in house or garden. In the house it can be trained about a window, forming a wreath of the most brilliant bloom both summer and winter. Flowers of a most intense scarlet, shading into flame, tipped with bright golden-yellow. Price, 10 cents each; three for 25 cents.

\section{Aspidistra}

One of the most useful house plants On account of its ability to thrive indoors it has been frequently aluded to as "The Cast Iron Plant." It has long, broadly lanceolate leaves gracefully disposed. Price, 25 cents each.

\section{Poinsettia Pulcherrima}

Coralline Lucerne Begonia.
This is the plant which produces the large clusters of red leaves or flowers which are seen in all the flower stores at Christmas. We offer fine plants. Price, 25 cents each.

\section{Banana Orinoco}

One of the finest Bananas and fruits splendidly. The leaves are borne in a palm-like crown or cluster, each leaf three to five feet long and two feet broad; of a clear shining green, curved and crinkled in a most pleasing manner. The most beautiful foliage plant that can be grown outside of a hothouse. Grand for bedding out in the summer, for conservatory or warm window decoration. Can be kept unwatered in a warm cellar over winter. Price, 25 cents each; five for $\$ 1.00$; large, by express, 50 cents each. Extra large, $\$ 1.00$.

\section{Where Grass Won't Grow}

These vines will cover the ground.

HARDY MOSS PINKS (Creeping Phlox)-Pink and white flowers. $15 \mathrm{c} ; \$ 1.50$ per dozen.

EVERGREEN HONEYSUCKLE-White flowers; recommended for embankments. $25 \mathrm{c} ; \$ 2.50$ per dozen.

MONEYWORT-Evergreen; will grow in dense shade. 10C: $\$ 1.00$ per dozen.

VARIEGATED GROUND IVY-Beautiful foliage; fine for covering graves. $15 \mathrm{c} ; \$ 1.50$ per dozen.

TRAILING HOUSELEEK-Yellow flowers; for edging and $\$ 1.00$ per dozen. carpeting bare spots, especially in cemeteries. $10 \mathrm{c}$; 


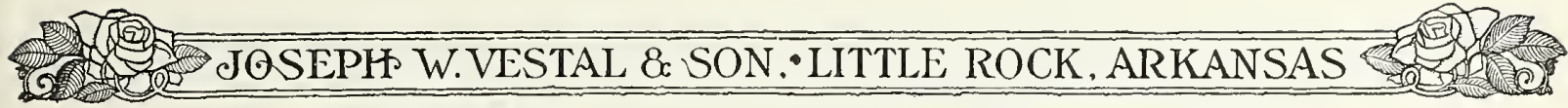

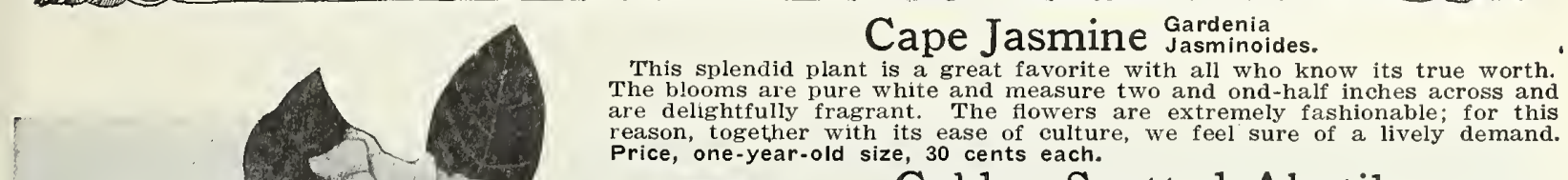

Golden Spotted Abutilon

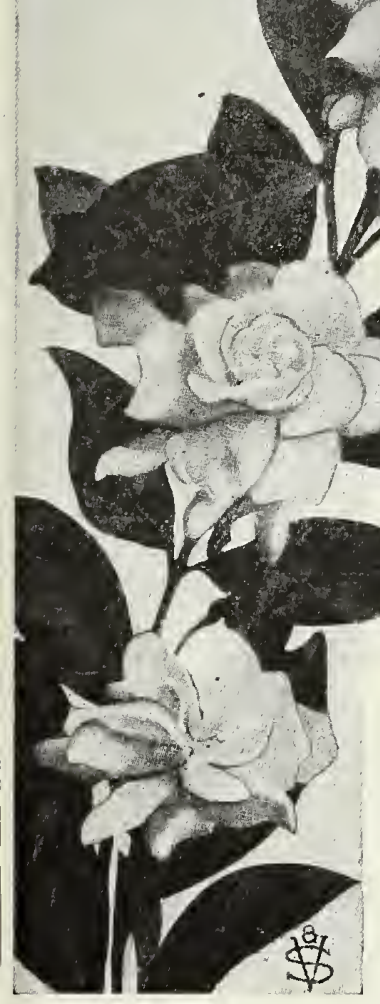

ECLIPSE. This is a novel and distinctive variety. The leaves are beautifully spotted with golden yellow on a green ground. The flowers are orange yellow, and are produced abundantly. An excellent plant for edging foliage beds. As a basket or vase plant it is unsurpassed. As a specimen in the window or conservatory it has few equals. Price, 10 cents each.

\section{Confederate Jasmine}

This makes an elegant hard wooded climber, or can be trained to bush form. It bears large branches of pure white flowers, with the most delicious perfume. Price, 20 cents each.

\section{Cestrum Parqui Night Blooming}

A beautiful tender shrub of easy cultivation; producing beautiful white flowers in clusters, and in the greatest profusion; overpoweringly sweet at night. Price, 15 cents each.

\section{Cestrum Diurnum Day Blooming}

A handsome quick growing evergreen shrub; producing quantities of sweet scented white flowers, valuable for cut flower work. Price, 15 cents each.

\section{New Coleus Defiance}

Poinsettia color with gold edge. This grand variety will supplant Winter Gem, to be grown as specimens for store trade. Price, 15 cents each.

\section{Coleus}

WINTER GEM. Has broad leaves that often measure eight inches across, beautifully marked with yellow and brightest crimson. Price, 10 cents each; larger, 25 cents.

TRAILING QUEEN. Elegant fringed leaves blending from pink to crimson, finely, scalloped edges. The plant is half trailing or running and is well adapted for window boxes, baskets or vases. Price, 10 cents each; per dozen, $\$ 1.00$.

YELLOW TRAILING QUEEN. A center wedge of creamy white bordered green; the whole margined yellow. Price, 10 cents each; per dozen, $\$ 1.00$.

\section{New Bedding Coleus}

The Coleus, a plant very familiar to all, is one which, for bedding purposes, can not be excelled. The foliage is very beautiful in many of the good newer sorts, and shows a great variety of markings and fine combinations. It is used in great quantities in private places, in small gardens and in the public gardens and parks. The Coleus is used to best advantage in planting in ribbons of color in the borders along drives, in beds of various shapes, such as stars, crescents, triangles, circles and squares, as the foliage, being of such various colors, can be used with striking effect Light colors against dark, with borders of contrasting color, which are easily obtained among the yellow, red, striped, mottled, brown, blue-black, plum and other colored sorts, secure effects

Cape Jasmine. when used on a fine lawn or in the border, hard to make with other plants.

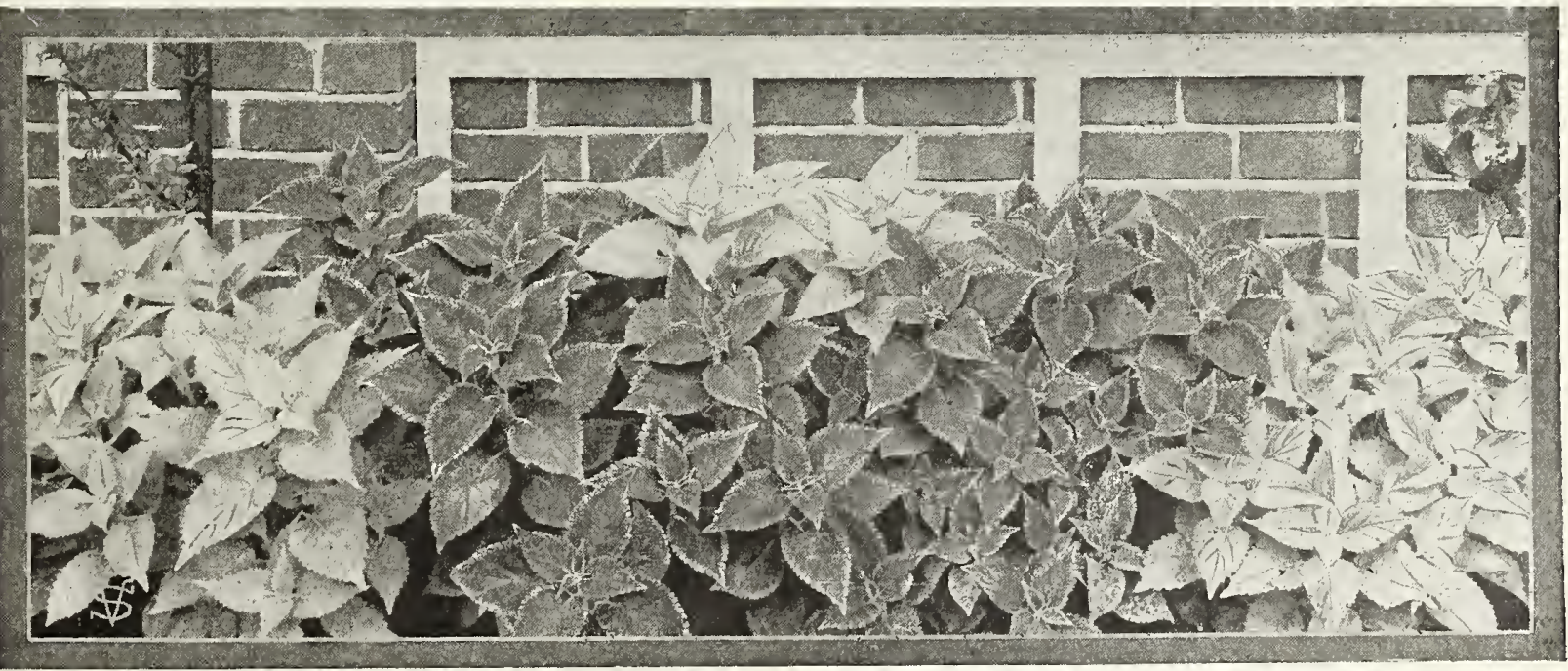

Vestal's Gorgeous Bedding Coleus. Price, 10 cents each; 75 cents per dozen; 100 plants for $\$ 4.00$. 


\section{CHRYSANTHEMUMS}

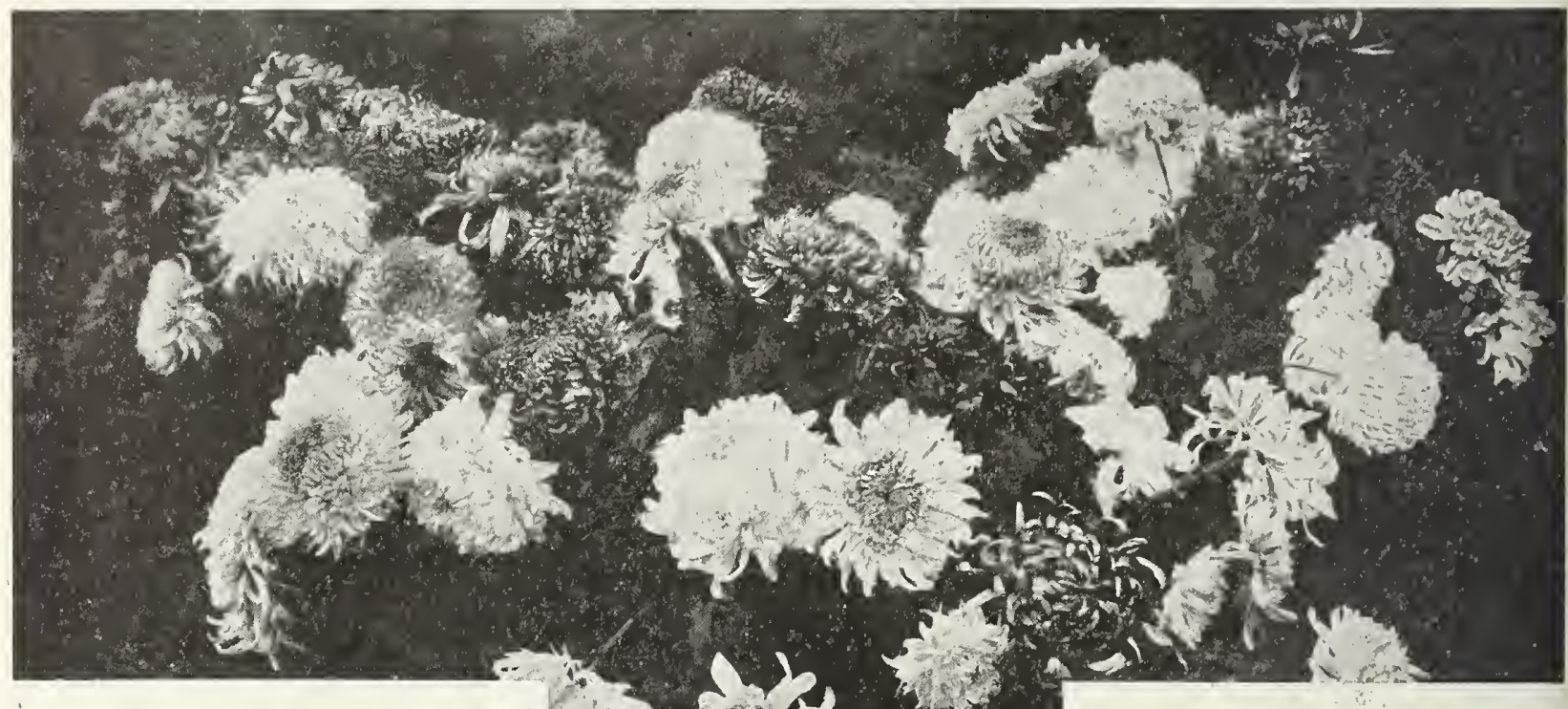

\section{New and Rare Varieties}

Prlce, 20 cents each; $\$ 2.00$ per dozen. ANTIQUE. A deep bronze sport of the favorite Dr. Enguehard. It is a duplicate of Enguehard in all respects save color.

AUTOCRAT. A commercial variety of great promise. Color snow white growth dwarf and robust.

BOB PULLING. One of the grandest exhibition yellows of recent years; of wonderful size, composed of petals an inch and a half in width, and 10 inches deep.

EDWIN SEIDEWITZ.' A beautiful late, incurved, bright pink, maturing from Thanksgiving to early December. Surpasses all late pinks we have grown.

JOSEPHINE FOLEY. The best white introduced last year. Purest white, strong in growth and stem. Early midseason.

HARVARD. Japanese reflexed, very dark crimson; in perfection November 15th and later.

HELEN LEE. A very delicate flesh or light pink, incurved and of very large size.

MISTLETOE. Blush white; strong, upright growth. One of the latest; not ready to cut until December.

MARIGOLD. A monster yellow; flower unsurpassed both in size and color in its season.

MRS. M. R. MORGAN. Very fine yellow; seedling of Timothy Eaton; splendidly shown last year.

NAGOYA. Fine late yellow; can be grown for Thanksgiving if desired.

ODESSA. Enormous yellow, very bright, grand in form; unexcelled in incurving yellow for exhibition.

SMITH'S SENSATION. A delicate shade of pink, of fine incurved form.

TEKONSHA. The best large flowering bronze. Strong upright growth. Those desiring a late bronze should not overlook this vriety.

YELLOW WM. TURNER. The yellow sport from Turner; a necessity for collections and for variety. Perhaps the finest incurved pink commercial variety in cultivation today.

CHAS. RAZER. A good commercial pure snow white, as handsome as Eaton.

COL. D. "APPLETON. A very large, deep golden yellow. DR. ENGUEHARD. Beautiful true pink. Ball shape. DICK. WITTERSTAETTER. An intense shade of red.

DAKOMA. A grand bronze of large size and beautiful form.

GLACIER. Pure white; we have never seen anything larger and more impressive.

GETTYSBURG. The color is of the richest velvety crimson. The outer petals are broad and drooping, and have a lustrous sheen in the sunlight.

GOLDEN WEDDING. The flowers are a great fluffy mass of clear golden yellow.

MRS. H. H. WEEKS. An immense flower with broad claw-like petals incurving to form a globe of white.

MRS. ROBERT FOERDERER. A fine globular flower of unique color, soft creamy yellow, with light amber shadings. M. ANTONIN MARMONTEL. One of the most beautiful of Chrysanthemums; the color is rosy crimson.

ROMAN GOLD. A darker yellow than Golden wedding.

SILVER WEDDING. The purest white, with broad, reflexed petals, forming a bold, handsome flower.

TIMOTHY EATON. One of the largest, and a winner of every cup and prize for which it was entered. Purest white, of true globular shape.

WHITE CLOUD. There is no grander white variety, no matter when it blooms.

WM. TURNER. A decided incurve of the purest white; flne form and a strong grower with clean foliage. 
A selection of very early flowering varieties which will furnish an abundance of flowers under ordinary cultivation during October, after Dahlias and other tender plants have been cut by frost. Price, 15 cents each; $\$ 1.50$ per, dozen.

ADELE GRISWOLD. An enormous flower of pure bright pink, with foliage well carried. Form and color grand. Five feet. One of the best.

CRYSTAL GEM. Early commercial, large in size, a good clear white, artistic in form, good stem and foliage.

CLEMENTINE TOUSEET. A very large, loosely incurving bloom, flowering early in October. Pure white.

CHRYSOLORA. This new variety can be briefly decribed as an early Col. D. Appleton.

DONATELLO. Bright yellow, ball-shaped.

EARLY FROST. Most popular early white, coming into flower September 15 th $h$ onward.

GOLDEN QUEEN. Fine, incurved yellow; form very double from any bud; a suggested improvement on Golden Glow.

ocoNTO. White; fine large blooms on very strong stems; langely grown for its period, which is early midseason.

OCTOBER QUEEN. (Smith, Commercial, 1916). Snow white, with incurving center and horizontal outer petals. Very promising as an early.

RAMAPO. Color of Col. D. Appleton, splendid foliage. A first-class yellow.

TIGER. (Smith, 1916). This is the variety named by President Wilson. Very round and finely finished into a perfect incurved.

YELLOW TOUSET. The yellow sport from C. Touset, exactly like it save in color.

UNAKA. A fine incurving bloom of a pleasing shade of pink.

\section{Pompon Chrysanthemums}

These beautiful small flowered varieties are again coming to the front, and are certain to become popular for outdoor bedding purposes. They are absolutely hardy, and produce an abundant, almost lavish, profusion of blooms, and the plants lend a coloration to the garden just at a time when other plants have been destroyed by frost. Frost does not materially affect the flowering. The collection embraces all the leading colors, and, with but a slight covering of leaves or coarse stable litter during the winter, will take care of themselves after once planted.

Price, 10 cents each; 3 for 25 cents.

CLORINDA. Semi-dwarf, producing erect sprays of an ven shade of bronze.

DIANA. A fine pure white.

EUGENE LANGAULET. Pompon anemone. There is nothing handsomer or more profitable among the small 'mums than this classy little shining, golden yellow Pompon GOLDEN CLIMAX. A very pleasing shade of bright yelow; medium.

GOLDEN WEST. A small golden yellow flower of great substance.

HELEN NEWBERRY. Two inches in diameter, high, rounded flowers of purest white, maturing Thanksgiving to Christmas, when most Pompons are gone.

INGA. Bright red of beautiful shade, fine size, and elegant form; one of the earliest.

KATIE MANNING. Very early yellow, extra good; can be cut for three weeks; opens flat, gradually reflexing into a globe.

KLONDIKE. Most beautiful yellow in the family; extra

LITTLE вов. Small red flowers, very free and pretty.

MINTA. A very free flowering light pink, unsurpassed by any of this color. Owing to its upright growth is one of the best for specimen plants.

NIZA. Delicate shell pink; very valuable owing to its being the very earliest of its color-matures October $10 \mathrm{th}$ medium sized blooms on dwarf plants.

QUINOLA. Stiff stemmed, golden yellow; a favorite.

SNOWDROP. Pure white; small flowers; very profuse bloomer.

SKIBO. Earliest of all; opens bronze, maturing into yellow.

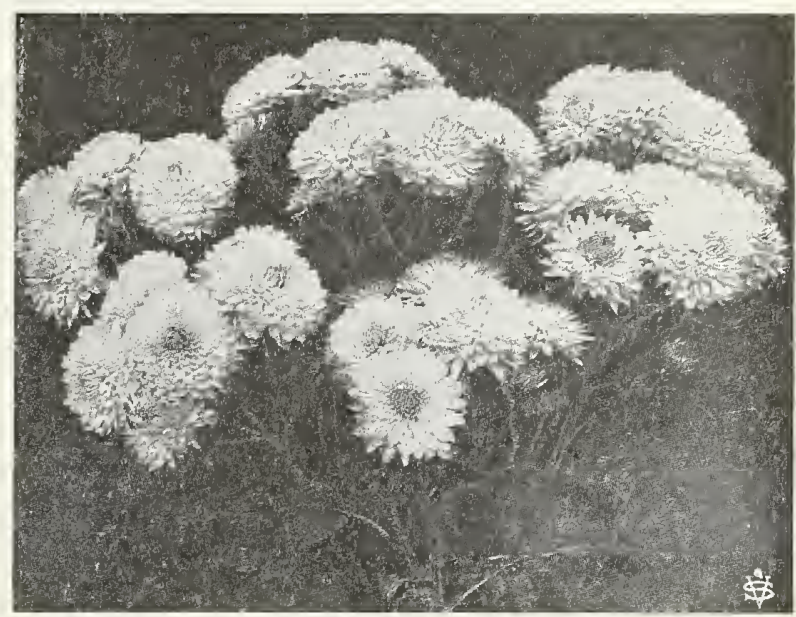

Pompon Chrysanthemum Golden West

\section{Single Varieties}

This type, although long ignored and in many places almost forgotten, has been recently shown in fine form, and now no exhibition will be complete without its Classes and Singles. For bush plants, decorative pot plants and table decorations, the Singles excel, and when well grown they displace and command more admiration than any of the large flowering types.

\section{Price, 10 cents each; 3 for 25 cents.}

ANNA. Pure white, belongs to the true single section, having but one row of petals. Fine for pot plants.

CLEA. Growth upright, forming large sprays of a delicate shade of light pink.

CEDDIE MASON. Bright crimson; medium-sized flowers make wonderful display.

CATHERINE LIVINGSTON. A pleasing shade of lavender pink, strong growth, producing fine sprays.

LADYSMITH. Early pink; useful for bush plants.

LILY GODFREY. Medium size, rosy lavender.

LITTLE BARBEE. Clear canary yellow, exceptionally large sprays of medium sized flowers.

HILDA WELLS. Beautiful Tuscan red, with a light yellow tinting at base of petals.

MRS. ALICE BROWNSON HUTSON. Daybreak pink; quilled in center; very fine.

SYLVIA SLADE. The showiest of all singles, the flower like a giant Cineraria, color rosy-garnet, with broad white ring around the disc.

\section{December Flowering Chrysanthemums}

To those having a small greenhouse, or are prepared to give them protection in any way, the following varieties can easily be had in flower at the Christmas holidays. Price, 15 cents each; set for $\$ 1.00$.

DECEMBER GEM. A ball-shaped white, with pink stripe on edge of petals, giving a pink or pearly tint to the bloom.

HELEN FRICK. Color a beautiful clear pink (like the Mermet Rose), slightly deeper at the center.

LAVENDER QUEEN. It is a lovely color, soft silvery lavender pink, decidedly distinct from any other pink.

OSPREY. A very late white of medium size, of absolutely perfect form, like a Dahlia.

THANKSGIVING QUEEN. An improved Silver Wedding, being larger and almost double. Color creamy white.

WHITE HELEN FRICK. When mature are pure white.

YELLOW DECEMBER GEM. Light primrose yellow, with whorled petals-large sized bloom.

DECEMBER QUEEN. Bright yellow, approaching orange: incurved and double. 


\section{CHOICEST VARIETIES OF CANNAS}

High-grade Cannas have for years been one of our leading specialties, and our fields the past season were a gorgeous riot of color from June to frost, and were admired by many visitors. To those who stopped to look closely at individual varieties, the wonderful improvement in Cannas was very manifest. No other bedding plant will give the same uniform good results in our varied and trying climate. They do well in all sections of the country and stand pre-eminently at the head of the list, succeeding in any sunny position in any kind of soll, but responding quickly to liberal treatment. For best results the beds should be spaded two feet deep and a generous amount of well-decayed manure of any kind thoroughly incorporated, and at all times supplying water freely. For best effect plant in large masses of one color, setting out the plants 2 feet apart.

\section{Allemannia}

The giant of all Cannas. Produces the largest flowers. The outer petals are scarlet, with very broad, golden yellow border. Inside of bloom is scarlet and dark red. Price, 10 cents each.

\section{Burbank}

A giant in size. Beautiful, rich, canary-yellow, the throat finely spotted crimson. Price, 10 cents each.

\section{Buttercup}

A profusely blooming Canna, of pure "Buttercup" yellow. There are many yellow varieties of various shades and markings, but for a clear, solid yellow bed, Buttercup is unsurpassed in its height. Price, 20 cents each.

\section{Beacon}

Moderate-sized flowers of rich cardinal-red, borne in impressive heads that make a mass of color almost unparalleled. Price, 15 cents each; $\$ 1.50$ per dozen.

\section{City of Portland}

Beautiful glowing salmon-pink flowers produced in greatest profusion on strong, branching stocks. A wonderfully fine Canna whose unceasing bloom makes it one of the best pink bedders in existence. Price, 25 cents each; $\$ 2.50$ per doz.

\section{Chas. Henderson}

Rich crimson flowered Canna. A splendid dwarf, compact grower, throwing up direct, compact heads of bloom of immense size. The individual flowers are among the very largest. Color, dark crimson; center of the flowers marked with gold pencilings. Price, 10 cents each; $\$ 1.00$ per dozen.

\section{David Harum}

Bronze leaved; flowers of bright vermilion-scarlet, mottled with deep red. Plants, 20 cents each; $\$ 2.00$ per dozen.

\section{Gaiety}

Reddish-orange mottled with carmine and edged with yellow. The tongue is yellow and densely spotted with carmine. Price, 25 cents each.

\section{"Gloriosa"}

Color is a brilliant vermilion-scarlet, bordered with deep golden-yellow; the flowers are borne in great clusters, and in such profusion that they crown the plant with a blaze of glowing color. 15 cents each; $\$ 1.50$ per dozen.

\section{Italia}

Great crinkly petals of clear yellow, irregularly overlaid with varied shades of orange-scarlet. Price, 10 cents each; $\$ 1.00$ per dozen.

\section{SPECIAL PRICES ON VARIETIES OF CANNAS}

\section{in Quantity for Bedding.}

Order 10 cent Cannas at $\$ 1.00$ per dozen, $\$ 8.00$ per 100 order 15 cent Cannas at $\$ 1.50$ per dozen, $\$ 10.00$ per 100 ; order 20 cent Cannas at $\$ 2.00$ per dozen, $\$ 12.00$ per 100 .

\section{HOW TO ARRANGE CANNAS IN A CIRCULAR BED}

Get the tallest-growing varieties in the center, and then carefully grade each succeeding circle, using dwarf kinds for the outside. Plant one Canna in center of bed, next six Cannas 18 inches apart in a circular row 18 inches from center. For each succeeding circle use six more Cannas than were used in the previous circle and make 18 inches farther away from the center. A 10 -foot bed thus planted will contain 1 Canna in center, 6 in first circle, 12 in second circle and 18 in outer circle, all 18 inches apart.

\section{Triumph}

A handsome shade of deep, rich crimson. Large flowers in fine, well built trusses, borne erect on strong stems. A good, vigorous grower and constant bloomer. Price, 15 cents each; $\$ 1.50$ per dozen.

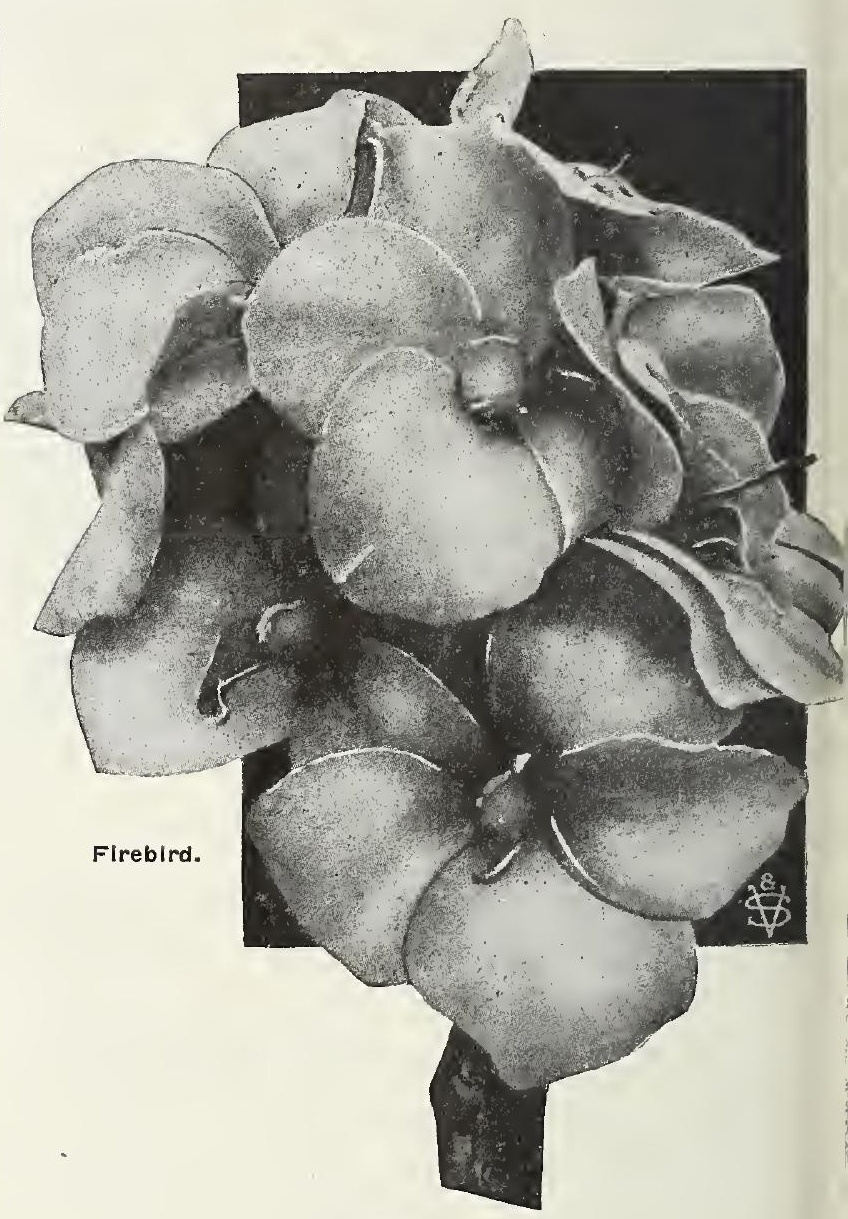

\section{Firebird}

This variety has been exploited for two years as a novelty, but the demand for it so greatly exceeds propagation, it must still rank with those of first consideration. The trusses are very large, compact and showy, with nicely rounded petals $2 \frac{1}{2}$ inches and more wide. Stalks are firm, upright, and bear their burdens well above the green foliage. The color is extremely desirable, being absolutely pure scarlet, with no suffusion, streaks or blotches whatever. A bed of Firebird is not only conspicuous-it is a regular conflagra. tion! Height medium. 30 cents each; $\$ 3.00$ per dozen. 


\section{CHOICEST VARIETIES CANNAS}

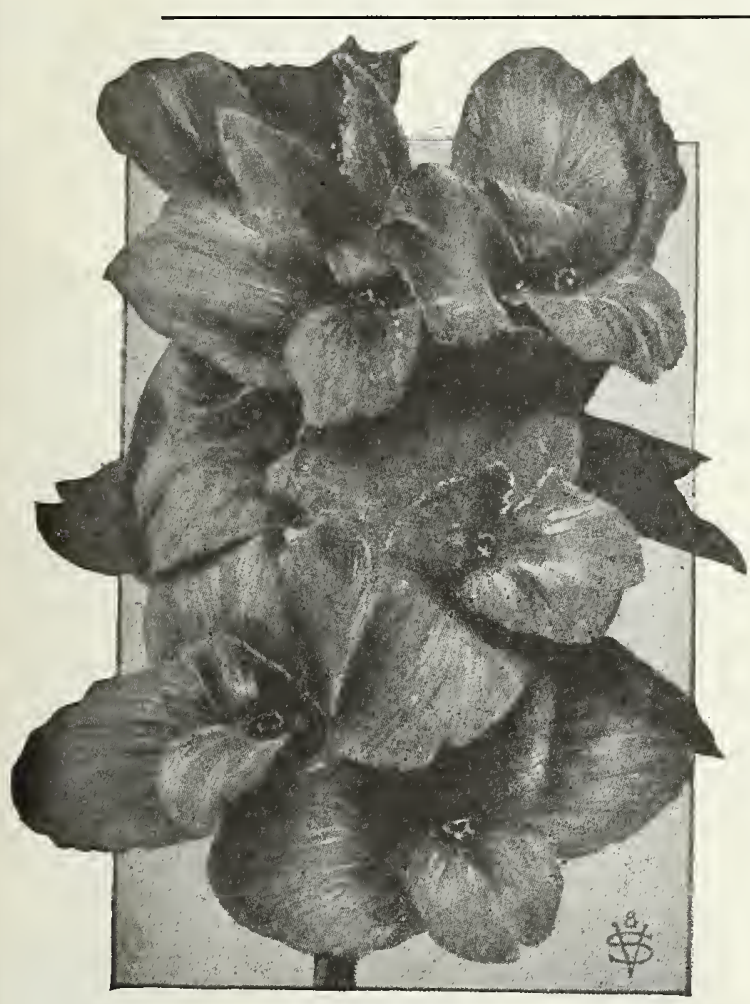

King Humbert

\section{The King of All Cannas} KING HUMBERT

In this grand Canna we have a combination of the highest type of flower with the finest bronze foliage. The flowers are as large as those of any of the Orchid flowering kinds, yet they have the firmness and substance of the Crozy typt. Its flowers are of a brilliant ordnge-scarlet, with bright red marking, while the foliage is broad and massive and of a rich copper-bronze. It is without doubt unsurpassed in the Canna family. Good strong plants, 20 cents each; 12 for $\$ 2.00 ; \$ 12.50$ per 100 , by express.

\section{Snowy White Canna,}

By all odds, the finest White Canna. Its great masses of snowy-white blossoms contrast finely with the splendid crimson and pink varieties, making the most gorgeous and showy flower beds for the lawn or garden it is possible to have. Strong plants, 20 cents each, postpaid; $\$ 2.00$ per dozen.

\section{Mrs. Alfred Conard}

One of the very best Cannas in commerce today. The large exquisitely shaded salmon-pink flowers are produced in great abundance on robust upright stalks; four feet. 25 cents each; $\$ 2.50$ per dozen.

\section{Louisiana}

The flowers are like beautiful orchids, size often more than 7 inches across, and every inch a vivid scarlet bloomer. Price, 15 cents each

\section{Martha Washington}

Extra large flowers. Color is clear bright rose-pink: prodiglous bloomer. The most showy and handsome of all pink Cannas. Price, 15 cents each.

\section{Pennsylvania}

The flowers are pure, deep scarlet, of immense size. A most excellent sort. Price, 15 cents each.

\section{Richard Wallace}

A tall growing, wide flowered, heavy trussed canary yellow, the largest and best of its color; bleaches very little. The longer we grow this variety, the more are we convinced it is the best all-'round yellow Canna we ever had. Price, 20 cents; $\$ 2.00$ per dozen.

\section{Souv. D'Antoine Crozy}

The color is an intense scarlet bordered with a band of deep golden-yellow. The foliage is broad and deep green. It grows about three to five feet in height, making a fine variety for the border of beds. Price, 20 cents each; $\$ 2.00$ per dozen.

\section{Splendor}

Massive heads of salmon-scarlet. Growth sturdy, but height only about three feet. Price, 15 cents each; $\$ 1.50$ per dozen.

\section{Wyoming}

A beautiful Orchid-flowering variety, with rich purplish bronze foliage. Flowers are large as King Humbert, and of good substance; bright orange, slightly rimmed and flaked

with rose. Price, 15 cents each. in Quantity for Bedding.

Order 10 cent Cannas at $\$ 1.00$ per dozen, $\$ 8.00$ per 100 ; order 15 cent Cannas at $\$ 1.50$ per dozen, $\$ 10.00$ per 100 ; order 20 cent Cannas at $\$ 2.00$ per dozen, $\$ 12.00$ per 100.

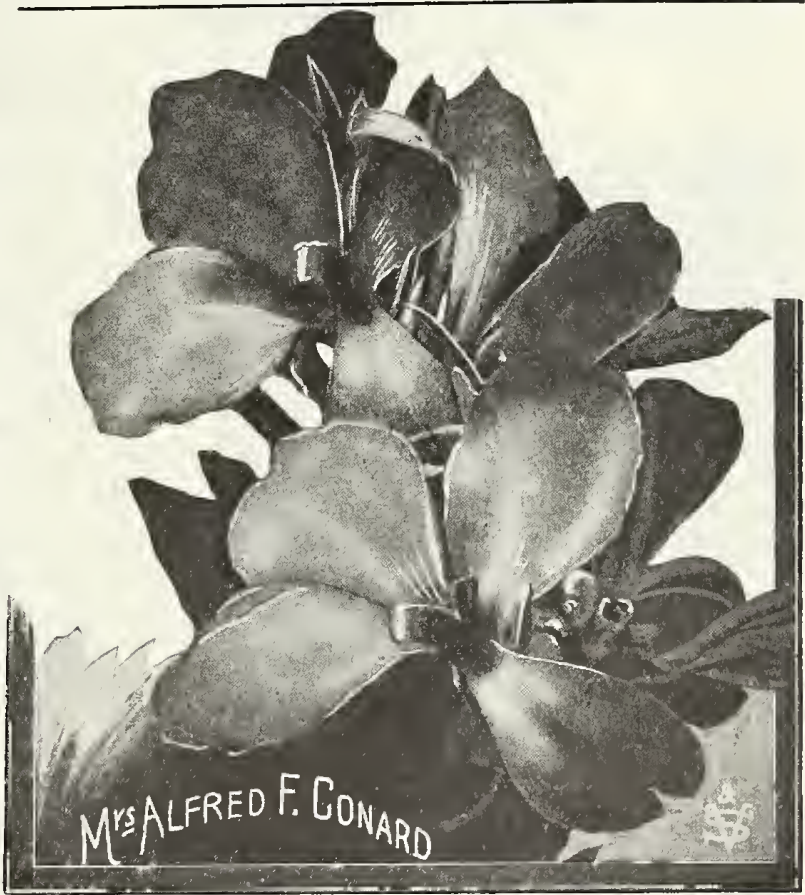

\section{For Effective Display Plant Canna Beds All One Color} For glaring, gorgeous color, grand foliage and profusion of bloom, nothing equals a bed of cannas. 


\section{GRAND GIANT DAHLIAS}

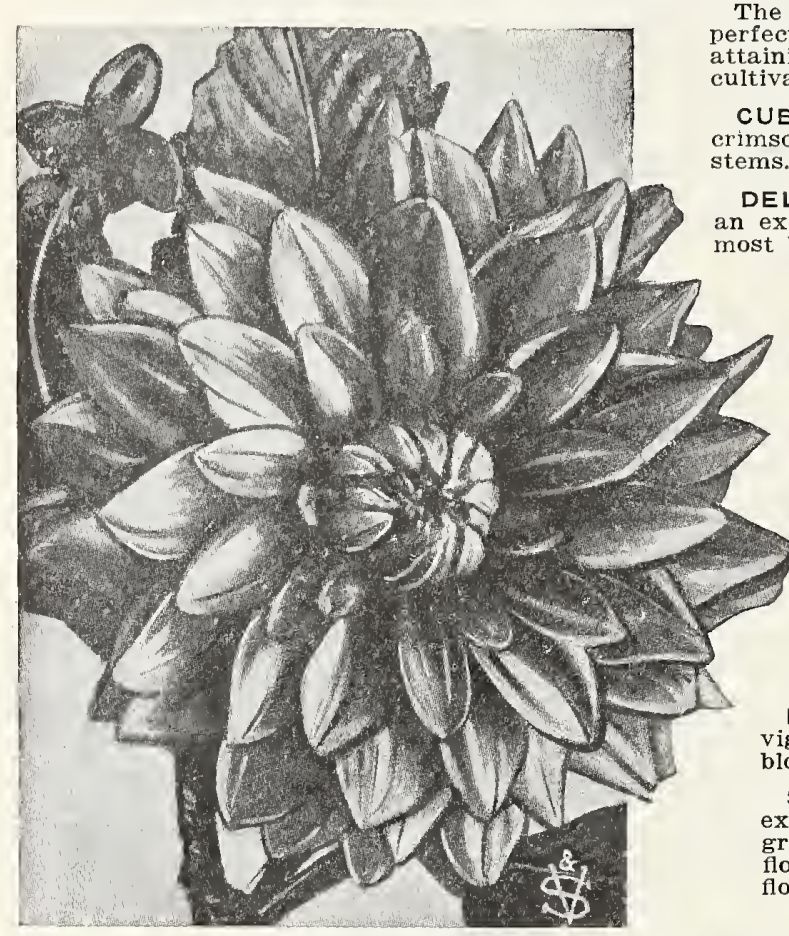

Jack Rose Dahlia.

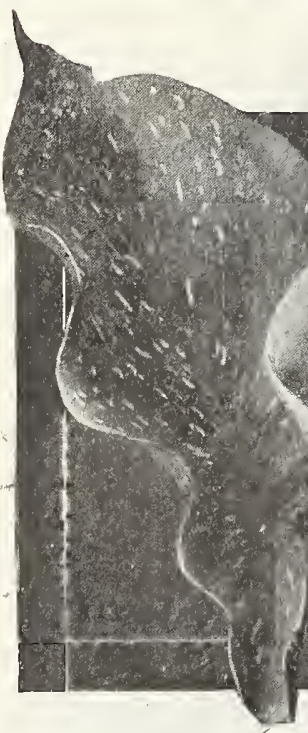

Spotted-Leaf Calla Lily.

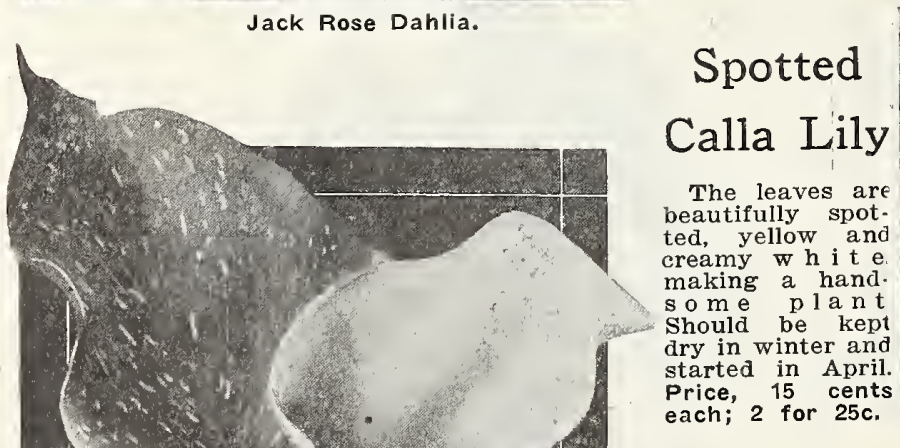

The sorts here offered are, without exception, the largest and most erfect double-flowering Dahlias now grown, flowers of all of them tize of between five and six inches across under ordinary

CUBAN GIANT. Flowers 6 to 7 inches in diameter; dark, glowing crimson shaded maroon; tall, strong grower with projecting flower

LICE. A large Dahlia of beautiful form and splendid size. It is n exquisite glowing rose pink, a soft yet brilliant color, one of the most beautiful we know.

JACK ROSE. Brilliant crimson-red, similar in shade to the popular "Jack" Rose, which suggested its name; perfect for garden decoration or for cutting.

COUNTESS OF LONSDALE. Extremely profuse bloomer; one of the very best. A pleasing blending of amber and salmon-pink.

MRS. ROOSEVELT. Of immense size and remarkably free flowering; color a delicate silvery rose, which is very attractive when cut.

QUEEN VICTORIA. Deep yellow, finely quilled. Flower's are of entirely distinct shape, globular in form, somewhat quilled. Extremely profuse bloomer on long stems, flowers being cut in sprays.

YELLOW COLOSSE. Flowers of very large size, of perfect form, pure primrose-yellow; the best of its color and valuable for all purposes.

RED HUSSAR, Intense scarlet-crimson. The plant is a strong, vigorous grower, with dark, glossy foliage. An early and free bloomer.

STORM KING. Still the finest of all white Show Dahlias. An extremely early, profuse and constant bloomer; a strong, vigorous rower of-dwarf, branching habit, producing large, perfectly-shaped flowers, on long stiff stems. One of the finest whites for cutflowers.

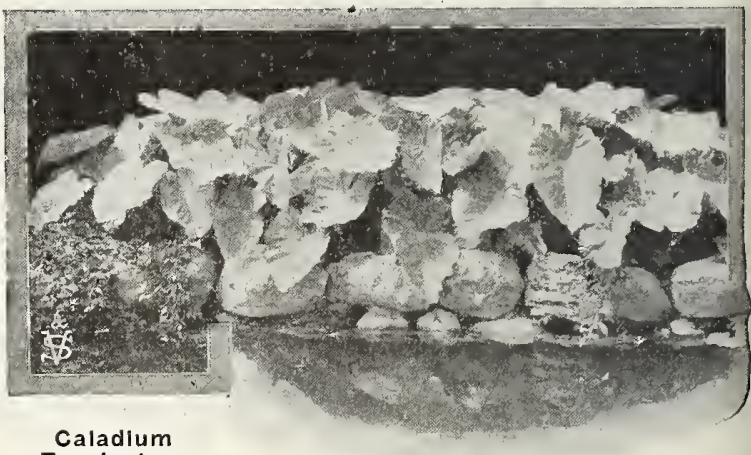

Caladium
Esculentum.

\section{New Yellow Calla, Mrs. Roosevelt}

This is the finest Yellow Calla yet produced. Flowers large and clear bright yellow; foliage deep green, finely spotted pure white; fine for house culture. Prlce, strong blooming size bulbs, 35 cents each; three for $\$ 1.00$.

\section{The White Calla or Llly of the Nile.}

This is one of our most highly valued house plants for winter and spring bloom. It should be dried off and kept dormant from the middle of June until September, then potted in good rich soil in four or five inch pots and given plenty of heat and moisture. Price, 20 cents each; two for 35 cents. A Word About Express Charges some florists are offering to prepay express charges on certain orders, but when A the same as for mail, the cost for sending being no more than it wer, are packed with a ball of soil on the roots, thus insurAll plants that wo send bj express, charges to be paid by purchaser, arsible consistent with safety.

ing their uninterrupted growth when received. We pack as light 
Gentlemen: Just a word to thank you for the beautiful plants sent lately. We set them out at once in the rain, so everything went right to growing. Your extra plants, roses, etc., was most generous. I must say I am very much pleased with everything. Will thank you again. MRS. L. M. HOWARD, Shreveport, La.

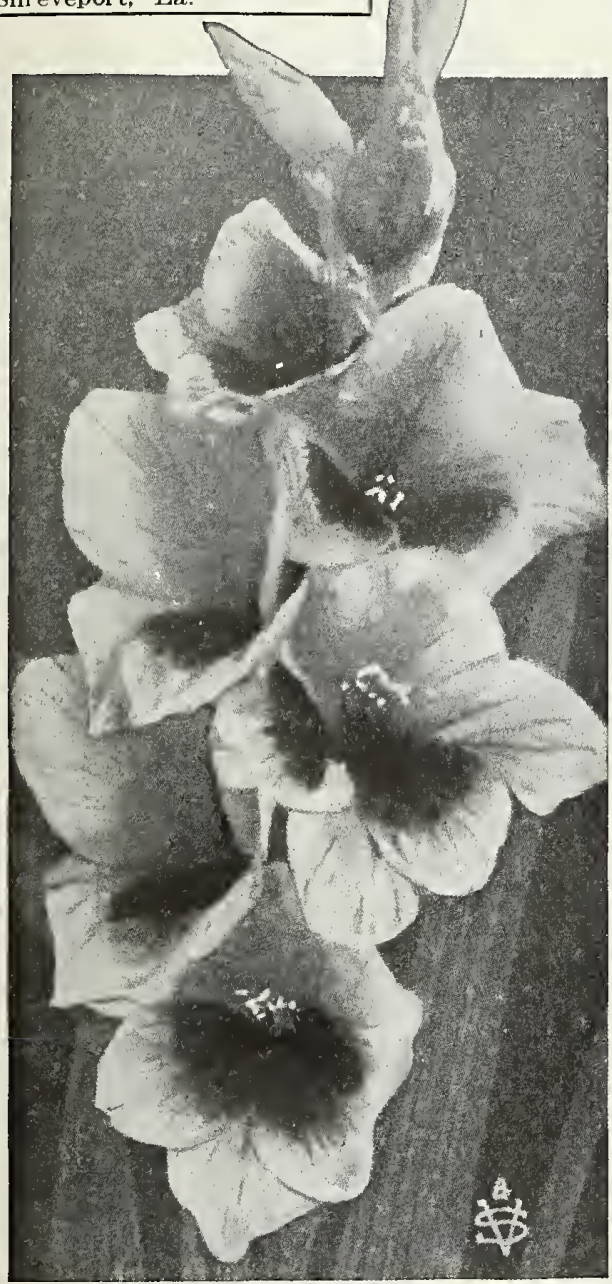

Butterfly Gladioli.

\section{Caladina}

FANCY-LEAVED. For conservatory or greenhouse; also suitable for outdoors when weather has become warm, in partial shade where protected from strong winds. 30 cents each; $\$ 3.00$ per dozen.

\section{Alocasia Illustris}

An excellent plant to grow in connection with fancy-leaved Caladiums or for planting in the open border in a partly shaded position. The foliage is large, of a dark green, clouded with a velvety blue black. Planted in light, well enriched soil, with a good supply of water, it makes plants two feet high, which form a striking object in sub-tropical gardening. Price, 25 cents each; five for $\$ 1.00$. $\$ 1.00$ each.

\section{Vestal's Summer Flowering Gladioli}

Among the most popular summer-flowering bulbs, and of high decorative value, either in the garden or as a cut-flower. All bulbs sent out by us are first class, sunny position about April 1.

GLADIOLUS AMERICA. The most beautiful variety in cultivacents each; 6 for 50 cents; 12 for 85 cents.

LEMOINEI, or BUTTERFLY GLADIOLUS. Known as Orchid-flowering Gladiolas. Crimson, white, brown, pink, etc. 6 for $30 \mathrm{c}$; 12 for $50 \mathrm{c}$.

GROFF'S HYBRID SEEDLINGS. Will produce the purest and most

\section{Our New American Seedling Gladiolus}

The most celebrated strain of Gladiolus in existence. Each bulb will bloom in ten weeks to three months after planting. All colors. 6 for 30 cents; 50 cents per dozen; $\$ 3.00$ per 100 , postpald.

\section{Caladium Arboreum}

This noble plant while young resembles the well known Caladium Escuentum, but grows to gigantic dimensions as it attains age, and while the atter dies down annually at the bulb, this grows into a stem or trunk, which retains the foliage through the winter if kept in the conservatory foom. Plants, under good culture, frequently attain eight to twelve feet in height. Price, from four and five-Inch pots, 50 cents and

\section{Caladium Esculentum (Elephant's Ear.)}

One of the most effective plants in cultivation for the flower border, or for planting out upon the lawn. It will grow in any good garden soil, and is of the easiest culture; but to obtain the best, results it should be planted in rich compost and plentifully supplied with water. Price, large strong bulbs, 20 cents each; six for $\$ 1.00$.

\section{Cinnamon Vine}

Well-known hardy climber; quick grower, with beautiful glossy heartshaped leaves and sweet-scented flowers. Vines will run 25 to 40 feet in one season. Good roots, each, 10 cents; 3 for 25 cents.

\section{Madeira Vine (Mignonette vine.)}

The glossy, waxy leaves of this dainty vine from the Andes makes it, perhaps, the most liked of all climbers. The leaves are light green above and rosy chocolate underneath; flowers white and deliciously fragrant. Price, 5 cents each; 50 cents per dozen.

\section{Fairy Lilies}

(Zephyranthes). Beautiful dwarf, bulbous plants, very effective for masses or borders, flowering with great profusion during summer. ALBA. Pure white, $6 \mathrm{c}$ each; 50c per dozen. ROSEA. Large, rose-colored flowers. $6 \mathrm{c}$ each, 50c per dozen.

\section{Tuberoses}

Plant liberally of this beautiful summer flower. We offer only the finest bulbs.

WARF EXCELSIOR PEARL. Flowers pure white, very double, of immer dozen, postpald.

MEXICAN EVERBLOOMING. Bears snow-whit flowers. 10 cents each; $\$ 1.00$ per dozen, postpald.

NEW VARIEGATED-LEAVED. The leaves are bordered with white; white flowers. 10 cents each; 3 for $25 \mathrm{c}$; $\$ 1.00$ per dozen.

\section{Special Offer}

We send, postpaid, Nine Excelsior Peari Tuberoses, Three Mexican Everbloom. Ing and Three New Varlegated - leaved -15 in all-for $\$ 1.00$

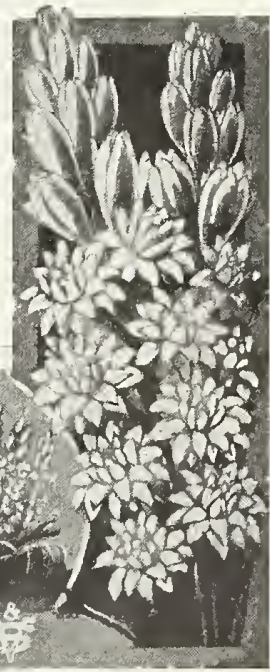

Dwart Pearl Tuberose. 


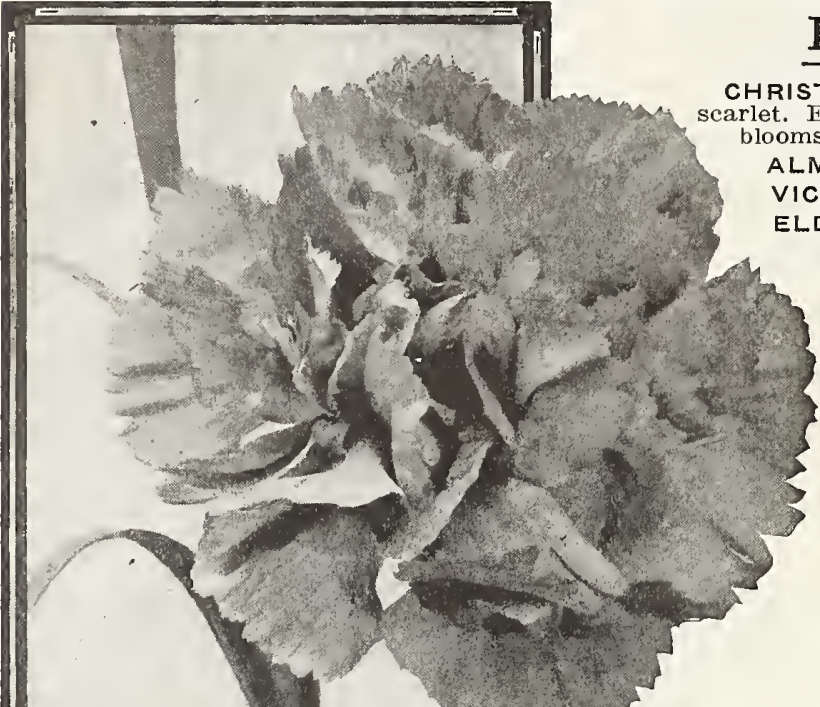

\section{Everblooming Carnations}

HRISTMAS CHEER. New. Color is a brilliant, glowing Poinsetta looms in a season. Price, 25 cents each.

ALMA WARD. New white; large: fragrant. Price, 15c each. VICTORY. Magnificent scarlet; very bright. Price, 15c each, LDORADO. Yellow penciled red; intensely fragrant. Prlce, 15 cents each.

ENCHANTRESS. Beautiful rose-pink; large. Price, 15 cents each.

CLIMAX. Rich salmon, prettily fringed; clove scented. Price, 15 cents each.

WHITE ENCHANTRESS. Snow-white; very rich fragrance. Price, 15 cents each.

\section{New Double Blue Lobelia}

KATHLEEN MALLARD. This beautiful and distinct Lobelia is a variety of the $L$. Speciosa which originated from a chance seedling. The color is the most beautiful and intense blue, the flowers each three-fourths inch in diameter and literally cover the plant. Price, 15 cents each; $\$ 1.25$ per dozen.

\section{Clerodendron Balfouri}

(Bleeding Heart Vine.)

We can safely recommend this great Clerodendron as one of the most satisfactory plants for window eulture now known. It is a vigorous, rapid, healthy grower, and produces an abundance of blooms which are bright crimson surrounded by pearly-white petals, producing a striking contrast against the dark green foliage. It can be used for a fine specimen pot plant, and can be grown to fine form by cutting off the ends of the growing shoots. A partially shaded position is conducive to rapid growth. Price, 25 cents each.

\section{Ficus Elastica \\ (Indian Rubber Plant.)}

Very large, smooth, leathery leaves; evergreen foliage. The plant attains a large size and tree shape. Each new leaf is inclosed in a long coral red envelope, looking like a great red flower bud. Price, 50 cents each; large plants, 75 cents each. We can also supply Ficus Elastica Variegata at $\$ 1.00$ each.

\section{Popular Oleanders}

\section{Kentia Belmoreana}

This Palm is not affected by the dust and dry air of the house, and will grow and thrive where few other plants would live. Plants, 12 inches high, 50 cents each.

\section{Phoenix Roebelini}

Resembles the beautiful Cocos Weddelliana in graceful foliage, but is much more vigorous in growth, and its gracefully recurving leaves, with very narrow, dark green pinnae, give it a lightness and airines not surpassed by any other variety. Large size, $\$ 1.50$ each.

Dear Sirs: My order of flowers reached me in perfect order last year and I received a prize and many compliments on my Coleus bed. The florists in our town wanted to supply me, but I have bought for many years plants from you and had such good success I could not make the change. MRS. W. A. W., Denton, Texas.

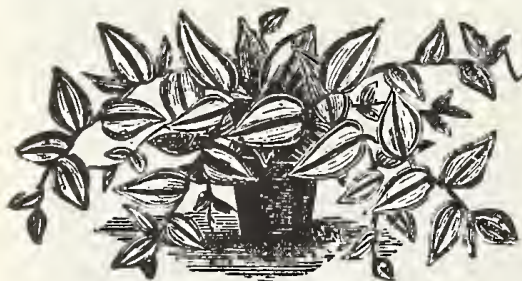

Wandering Jew

(Tradescantia Tri. color)

Most beautifully variegated purple, scarlet and white. Tradescantla Trlcolor Wandering Jew.

\section{Price, 25 cents each.}

These old-fashioned shrubs are becoming immensely popular again. No plant makes more handsome specimens in tubs for the veranda or yard. Can be wintered in the cellar.

OLEANDER ROSEA Double pink flowers; the old favorite; very sweet. OLEANDER LILIAN HENDER. SON - Double white flowers; fragrant.

\section{Cuphea}

\section{Llavea}

The stamens are pure white; the body of the flower is pea green and is covered with fine crimson hairs like a moss rose. The plants are always in bloom when given proper care. Price, 10 cents each.

CUPHEA PLATY. CENTRA (C I g a r Plant). Scarlet pendulous flowers; neat compact habit; constant bloomer. Price, 10 cents each.

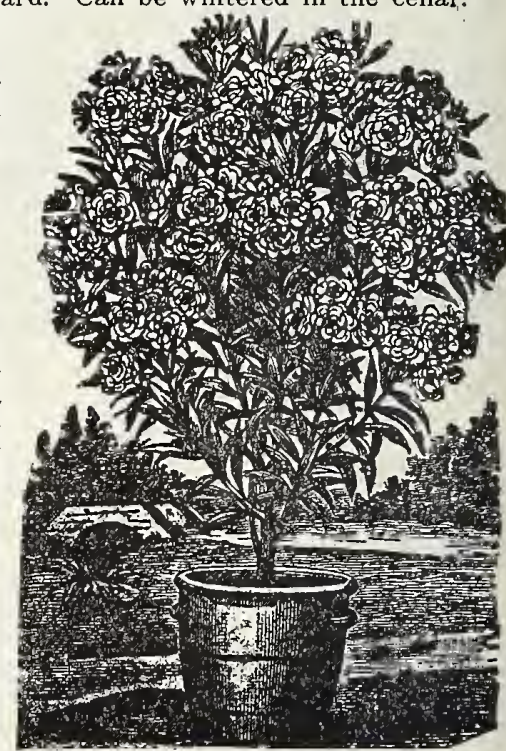


These beautiful plants for home decoration vie with the Palms for first place in the esteem of flower lovers. They are finely cut and oddly shaped. Ferns give a graceful effect produced by few other plants and they do exceedingly well in the parlor and conservatory. The Nephrolepis family, of which the well-known Boston is a member, has furnished us many beautiful species of late years. We recommend all the varieties listed.

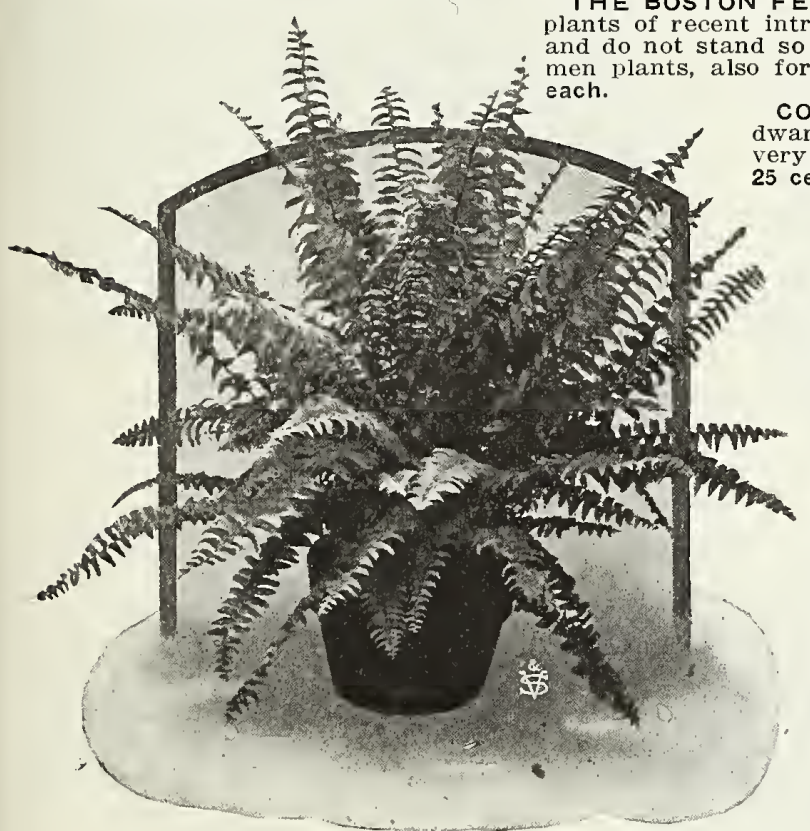

"Teddy Junior" Fern.

\section{New Fern John Wanamaker "The Wanamaker Boston Fern."}

Originated from Scholzelii, with longer, narrower, gracefully drooping fronds. It is not so compact in growth as Scholzelii, and therefore does not decay in the center, and is a durable house fern. It is a rapid grower, making an abundance of fronds, and is quite distinct from any other Fern. Price, nice plants, 25 cents each; larger plants, 50 cents each.

TEDDY JUNIOR. New dwarf Fern. Fronds are broad and beautifully tapered from the base to the tip, drooping just enough to make a graceful plant. Produces nearly four times as many fronds as any other Fern introduced. Compact, vigorous and thrives under most any condition. Price, 25 cents; large, 50 cents.

\section{Asparagus Ferns}

Their beautiful sprays of lovely, feathery foliage can be cut freely for bouquets, etc.

ASPARAGUS SPRENGERI. Emerald Feather. Very valuable for vases and baskets. A strong, vigorous plant, very easily grown and requires little care. Price, 15 cents and 25 cents each.

ASPARAGUS PLUMOSUS. Climbing Lace Fern. An extremely graceful window climber. The fine, feathery foliage is always bright and green. Price, 15 cents and 25 cents each.

\section{Moss Fern}

\section{(Selaginellia or Lycopodium.)}

Much used in fern dishes or grown up in four or five-inch pots. Its foliage is always fresh, green, very delicate and beautiful, lace-like. A bright, green creeper that in a short time completely covers the pot, and will spread on to anything within reach. Price, 15 cents each. more erect in growth, much darker shade of green, y gracefully arched. Very desirable as a house plant. Price, cents each; larger, 50 cents each.

WHITMANII. We think this the most popular Fern. Rather dwarf in growth, but graceful, very compact, dense and feathery. Each frond or branch has a double row of perfect little fronds set at right angles to the mid-rib, and so thick they seem almost crowded. It is a healthy, vigorous grower, constantly unfolding fresh fronds of light green that contrast exquisitely with the deep green of the older fronds, It is somewhat like Barrowsii, but decidedly more fluffy, more delicat,e and beautiful. Fine young plants, 25 cents and 35 cents.

PLUMED SCOTTI FERN. (Nephrolepis Scholzeli). The ideal plumed Fern, holding the same position to all other plumed varieties that Scotti holds to the old Boston. It is a sport from Scotti, possessing all the merits of that most popular variety, but with the pinnate sub-divided, giving it an airy, feathery appearance. Price, nicely shaped plants, 25 cents; larger 50 cents.

"HEIZERII." This magnificent Fern has never before been offered for sale by any florist or catalogue firm. It is a sport from the now famous Teddy Junior Fern, and while its habits of growth are to produce a shorter frond, it retains all the valuable characteristics of the parent plant. The fronds are broad and beautifully tapered from base to tip they droop just enough to make a shapely, graceful plant, permitting it to finish with a fine full center and perfect symmetrical spread. Price, 25 cents each; larger, 50c each.

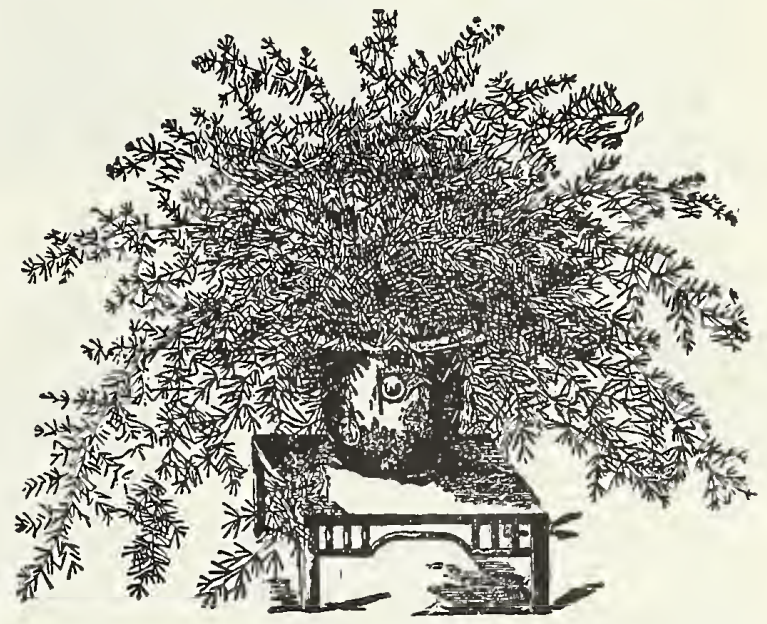

Asparagus Sprengerii.

PARLOR FOLIAGE COLLECTION.

4 Strong Plants for only $75 \mathrm{c}$, postpald.

In this collection we give you a strong plant of the best of all Ferns, "Whitmanii," also a plant of the new Fern "Scholtzi," together with a Boston Fern and a plant of the Lace Fern, for 75 cents.

FOUR ELEGANT WINDOW PLANTS FOR 75 CENTS 


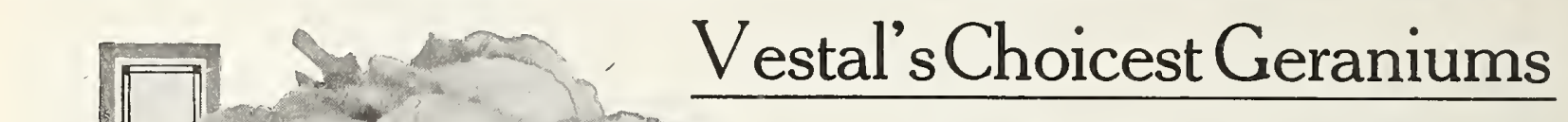

\section{Best Double Varieties}

Price, 15 cents each, or $\$ 1.25$ per dozen.

ALPHONSE RICARD. Produces flowers in great masses. Both fioret and truss are of enormous size. Color a brilliant shade of orange-red.

BEAUTY POITEVINE. The trusses of bloom and individual flowers are of immense size and excellent shape. Beautiful rosy-salmon, nicely shaded, and tinted deep orange to pure salmon.

BUCKNER. Large flowering, a fine bedder. Flowers white; not a trace of coloring at center. One of the finest whites.

BERTHA DE PRESSILY. Beautiful silver-rose of exquisite brightness; the blooms are extra large, very double; the habit is dwarf robust and branching.

JEAN OBERLE. An exquisite shade of hydrangeapink, fading to white at the outer edges; florets and truss extremely large.

LA FAVORITE. Pure white, elegant flowers of surpassing beauty; fine for bedding and cut flowers.

LUIGI GRANDI. Violet carmine, red on upper petals; a most handsome color.

MARQUIS DE CASTELAINE. Deep rosy-scarlet shading into pure scarlet.

MRS. LAWRENCE. Bright satiny salmon pink, slightly tinged white.

MRS. ANNIE VINCENT. Exquisite, semi-double flowers of a pure carmine color, somewhat maculated white.

RED WING. Deep cardinal red, with a soft velvety sheen unusually attractive; semi-double flower.

QUEEN OF CRIMSON, S. A. NUTT. The best dark, rich crimson bedding Geranium; blooms incessantly. This is the darkest and richest Geranium grown. It is a very bright, dark, deep rich velvety maroon, an excellent bedder and a perfect pot plant, one that must find its way into every collection. Stands the sun perfectly and is always a mass of bloom.

\section{Best Single Geraniums} Price, 15 cents each, or $\$ 1.25$ per dozen.

ALICE OF VINCENNES. A very distinct and pleasing combination of color; white ground with charming gradation of shades, from white throat through a beautiful shade of violet crimson to an intense scarlet margin.

DRYDEN. Bright cochineal red, shading to pure white in center.

GRANVILLE. Color the most beautiful shade of dark rose pink; white blotches on base of upper petals.

L'AUBE. Pure snow-white; splendid habit and growth of plant. Best single white to date.

MRS. E. G. HILL. Distinct and pleasing shade of salmon with light shading to center. Finest salmon flowered to date.

PANAMA. A very much improved Dryden. Much brighter in color with distinct white markings in the upper petals. Very free flowering.

\section{Apple-Scented Geraniums}

There are few, indeed, who are not acquainted with this grand old favorite. A plant of it will fill a room with its delicious odor, which is precisely like the fragrance of apple blossoms. Price, 20 cents each.

LARGE LEAF ROSE. Indispensable in the formation of bouquets.

MRS. TAYLOR. Fragrant foliage. Flowers scarlet magenta.

NUTMEG. Highly scented. A valuable variety.

CLORINDA. Large, neyron-red flowers.

DR. LIVINGSTON. A skeleton leaved, rose scented, with finely cut foliage.

LEMON. Lemon scented. A grand variety.

BALM SCENTED.

TRANSIT. An elegant new variety of Rose Geranium, with gracefully cut foliage.

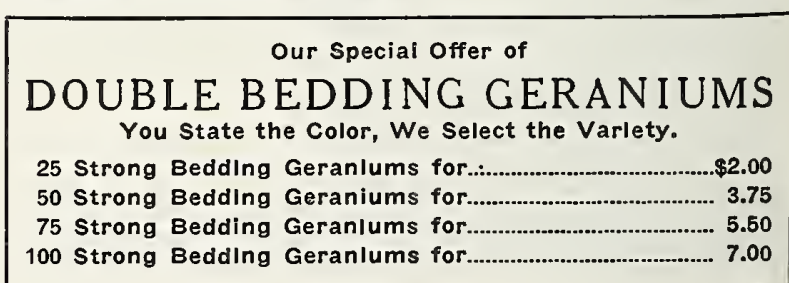




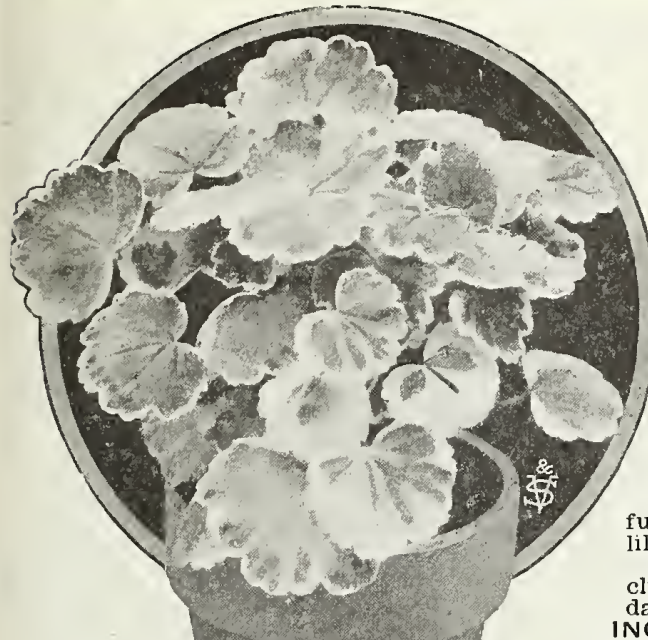

\section{VARIEGATED-LEAVED GERANIUMS}

Chielly remarkable for their bright, variegated foliage; very pretty and attractive particularly for pots and window culture. 15 cents each, 4 for 50 cents.

HAPPY THOUGHT. A tri-color Geranium with very dark green foliage, having a light creamy-almost white-center, with a dark band about the light zone. Flowers bright scarlet.

MAD. SALLEROI. A very compact variety of Silver Geranium. A thrifty, healthy grower, rarely reaching a height of more than six inches; leaves very small, of a peculiar clear green, edged with pure white.

VARIEGATED S. A. NUTT, A new introduction with liberal, healthy, remarkably beautiful variegated foliage; the green and creamy white being about evenly apportioned, of the same general form, freedom, character and color as the famous S. A. Nutt.

\section{Ivy Leaved Geraniums}

Nothing more desirable for baskets, vases or for any trailing or climbing plant utility. Price, 15 cents each, or $\$ 1.25$ per dozen.

ALLIANCE. A happy alliance of the soft, waxy finish of the Ivy class with the constitutional virility of the Zonales. The flowers are gracefully semi-double, very freely borne in trusses of conspicuous size. Delicate ilac-white, upper petals feathered and blotched crimson-rose.

CAESAR FRANCK. Enormous trusses of semi-double flowers, shaped and clustered much like "Crimson Rambler" Rose; vividly crimson, with a slight dash of rose at the base of petals.

NCOMPARABLE. Very large trusses and florets; a charming shade of nine-rose.

JEANNE D'ARC. Flowers very large; the purest white

RYCROFT SURPRISE. Bold, vigorous, upright habit; large trusses of a lovely shade of soft pink: free and effective.

Variegated Leaf Geranlum Mad. Salleroi.

\section{The Strawberry Geranium}

A Lovely Plant for Baskets and Vases. One of the handsomest plants imaginable, a gem of many colors. exceedingly rare and beautiful. Leaves nearly round, and striped freely with silver bandsblooms white, of great beauty and borne in spikes nearly twelve inches high; of easiest growth. Adapted for hanging baskets, vases, etc. Will stand neglect and mistreatment and grow very rapidly either in sunny place or shade. Price, 10 cents each; 3 for 25 cents.

\section{Heliotropes}

\section{Four Grand New Varieties.}

Heliotropes are universal favorites on account of their delightful fragrance and flowering equally as well as bedding plants in the summer, or as pot plants in the house during the winter. A bed filled with them produces a mass of color that can hardly be equaled by any other kind of plants. Indeed, there is nothing that will give so many sweet-scented flowers all through the summer as Heliotropes. They can be potted up in the fall and will flower more or less all winter.

ALBATROSS. Large panicles of pure white flowers in great profusion all season; the best white variety to date.

HEAVENLY BLUE. Large, close panicles of equisite light blue flowers, with white eye.

LAVENDER QUEEN. Very large trusses of a beautiful shade of lavender, suffused with rosy mauve.

ROYAL PURPLE. Color deep violet purple, with white eye. Price, 15 cents each; four sorts for 50 cents.

\section{Impatiens}

(Suitan's or Zanzibar Baisam.)

Charning plants for the decoration of the conservatory or window. Price, 15 cents each; two for 25 cents.

Gentlemen: I almost forgot to acknowledge the receipt of Roses and plants received from you last week. Was very well pleased with them. As ever, MRS. CHAS. BRAC'T, Fort Smith, Ark.
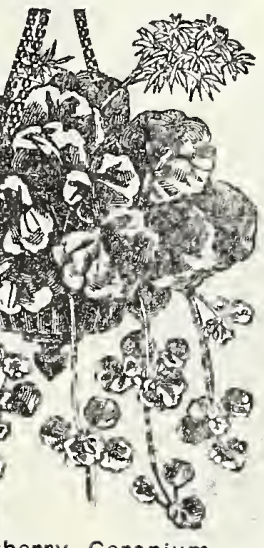

y ceranum

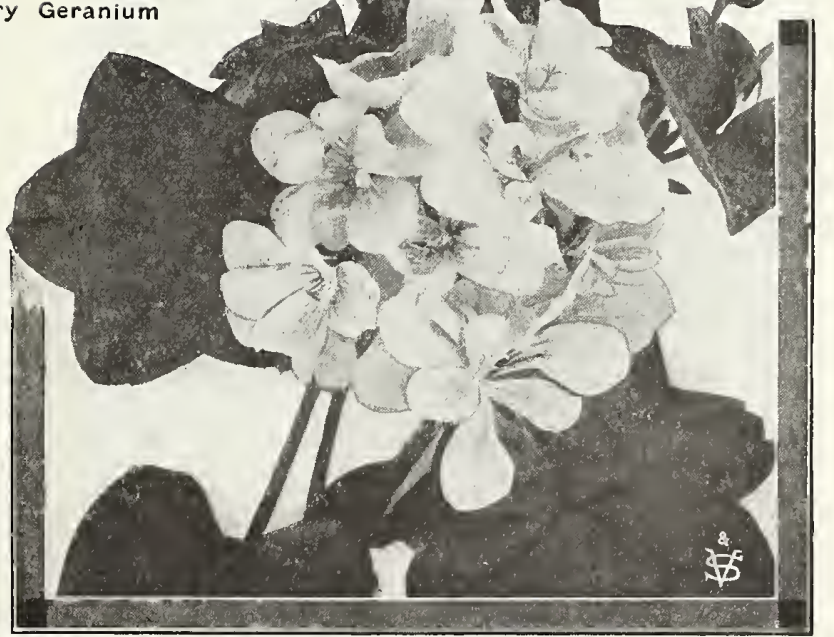

Ivy Leaf Geranium Caesar Franck.

Gentlemen: I received $\mathrm{my}$ nice box of plants and more Never before have them all. such lovely plants, all in fine condition and all living. Many thanks for your nice collection. I shall always send to you for plants ofrom now on. Your customer,

Marie, Ark. 
New Rare Large Flowering Hibiscus

(Chinese.)

Large growing tropical shrubs, with large glossy, dark green foliage, blooming freely in our hottest, sun, producing their enormous bright colored flowers in great numbers during the entire summer. Succeeds admirably out during the summer, producing a very tropical effect, the blooms averaging five or six inches in diameter and are gorgeously colored. The plants can be wintered over in a warm cellar or pit, and again bedded out in the summer. We have reduced the price, bringing them within reach of all. Price, first size, 15 cents each; second size, 30 cents; large size, 50 cents.

AURIANTICA. Large, double, orange colored flowers; an early and profuse bloomer.

BRILLIANTISSIMA. The largest flowered of all the single varieties. Color a brilliant scarlet, flushed with orange, the base of petal stained deep crimson; an extra fine variety.

COLLERII. Double; yellow, with maroon center; very fine; free flowering; best of this color.

GRANDIFLORA. Rich, glossy foliage, blooming profusely throughout the summer, literally covering the plant with scarlet crimson flowers.

LAMBERTII. Flowers large, deep crimson color; very fine.

PEACHBLOW. The flowers are double and from four to five inches in diameter; of a charming, rich, clear pink color

SUB VIOLOCEA. Flowers enormous, semi-double: clear carmine, tinted with violet. Probably the largest flower in the Hib iscus Chinensis family. An unusually free bloomer.

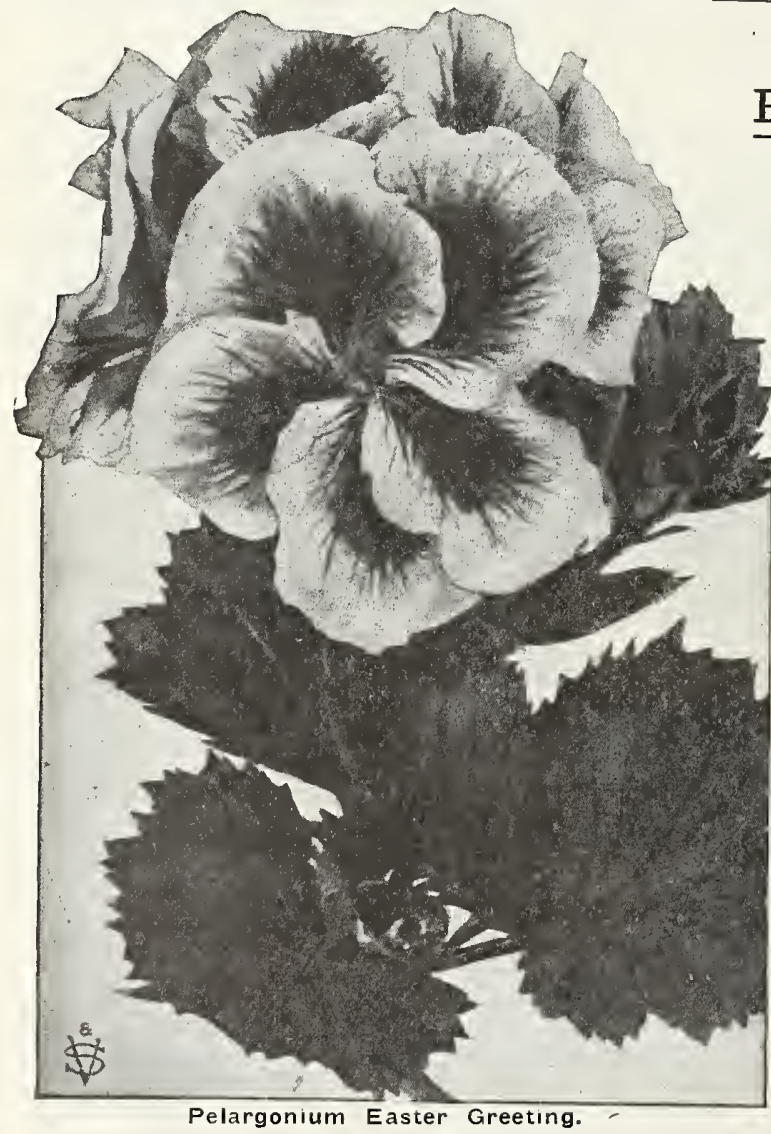

\section{Magnolia Fuscata}

\section{(Banana Shrub.)}

Desirable greenhouse shrub, succeeding admirably as a window plant. Produces its brownish yellow flowers late winter or early spring; exquisite fragrance, similar to a ripe banana. Strong plants, 60 cents each.
The New Everblooming Pelargonium

\section{Easter Greeting}

The flowers of Easter Greeting have the large size and-the gorgeously rich coloring of the "Lady Washington Geranium." To this is added, in Easter Greeting the habit of continuous blooming, which has made the ordinary bedding Geranium so highly valued. Easter Greeting is the first of a new race and one of the most valuable introductions in recent years. As an Easter plant it rivals the Azalea: but unlike the Azalea, Easter Greeting will remain in full bloom all summer. Each, 15 cents; larger, 50 cents.

\section{Pelargonium Novelties}

Price, 20 cents each; set of 7 for $\$ 1.25$

SWABIAN MAID. This new sport of Easter Greeting has large reddish carmine flowers with five very regular black blotches bordered with purplish carmine. Very effective coloring. Its habit, foliage, robust growth, and everblooming qualities are like its parent Easter Greeting.

WURTEMBERGIA. Medium sized florets of a bright carmine, with large velvety, sharply defined blotches.

WOLFGANG. Florets large and slightly crimped, ground color, reddish carmine, with five well defined violet black spots.

GARDENERS JOY. The ground color is apple blossom pink, the two upper petals have blotches of carbon brown.

PRINCE BISMARCK. Immensely large flowers, strongly crimped of fine shape, with from six to ten petals, color rich purple with velvety black blotches.

GERMAN GLORY. The upper petals contain two large purple magenta red spots, distinctly veined. An exceedingly beautiful and entirely new color in pelargoniums.

LUCY BECKER. This grand novelty is a sport of Easter Greetings and is like it in everything but color, which is a rosy-pink. It is, if anything, even more free in bloom.

\section{New Marguerite}

MRS. F. SANDER. Unlike all other Marguerites, its color is of the purest glistening white throughout; in size it frequently measures five inches across; the center of the flower is a mass of closely arranged fringed florets; these are surrounded or edged by the broad, shining white ray-petals, forming a flower which reminds one forcibly of a glorified double Pyrethrum. These are produced on long stems with a freedom not known in other varieties of the Marguerite. 


\section{SPLENDID FREE-BLOOMING LANTANAS}

EASILY GROWN; SURE TO BLOOM

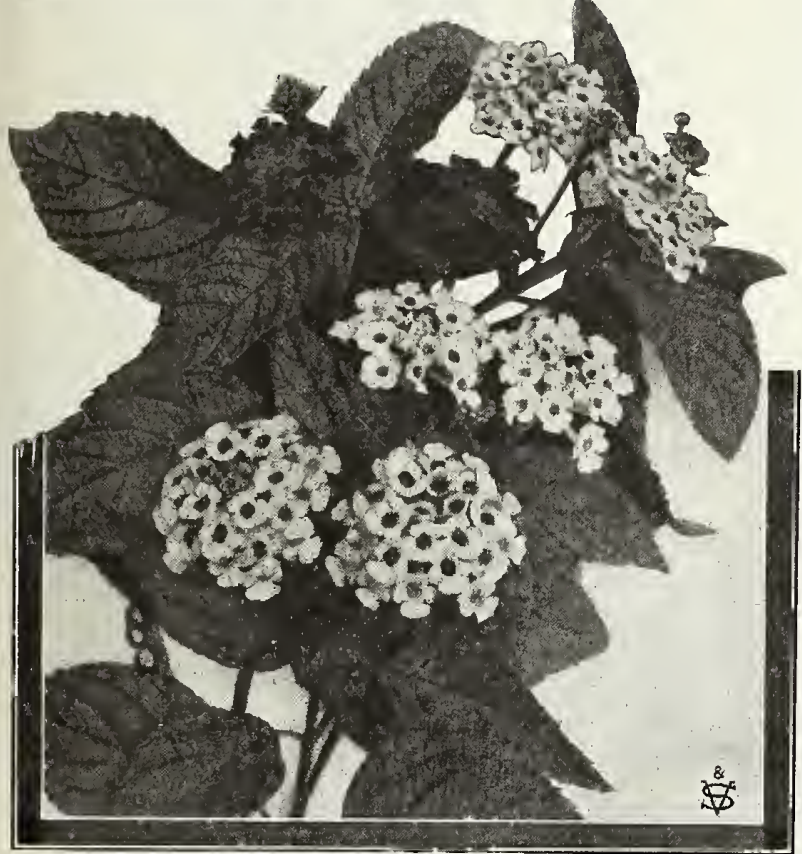

Lantana or Bush Verbena.

\section{New and Beautiful Fuchsias \\ Easily Grown; Sure to Bloom.}

For ease of culture, varied colors, profusion of bloom and adaptability to all localities we strongly recommend Fuchsias, the best varieties of which are offered in the following list, They are suitable alike for winter blooming or for growing outdoors, either in beds or in pots, boxes or vases, as the case may be. A collection of flowering plants is not complete without Fuchsias, and the extremely low price at which splendid sorts are offered permits of a choice collection of different varieties. Price, 15 cents each; 4 distinct kinds for 50 cents.

\section{Weeping Lantana}

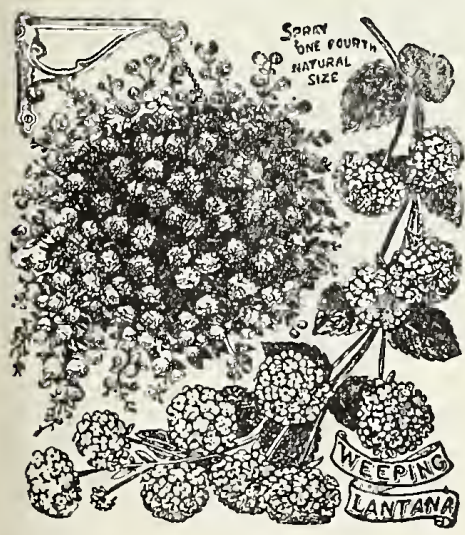

A New Weeping Plant of Great Beauty.

One of the grandest plants grown. The The plant has a most graceful, d r o o p ing habit, grows very rapidly and blooms continually summer and w in t e $r$, producing large clusters of flowers of the most delicate lilac or rosy-pink. of nothing of recent introduction that is so easily grown and gives so much pleasure and satisfaction as this beautiful L a n t a na. each; $\$ 1.25$ per dozen, postpaid. Foliage a beautiful dark green. We know
THE VERY BEST AND NEWEST VARIETIES.

Try a few Lantanas this year for bedding. They stand sun and drought remarkably well, and are never out of bloom. Grown in pots or tubs, they make splendid specimen plants for porch or lawn, and can be kept in a light cellar during the winter. Price, 15 cents each; four for 50 cents.

A. Cook. Dwarf; opens orange and yellow; changes to bright rose; a free bloomer; foliage and florets small; very pretty.

ALBA PERFECTA. Pure white. A gem among white bedders.

FRANCINE. Quite dwarf; flowers large; rosy lilac.

JAVOTTE. Center bright yellow; light border; very free bloomer; a good variety.

JACQUES MINOT. Plant vigorous but compact in growth flower at first opening is deep orange red, changing to deep vivid crimson; very fine, and brightest Lantana we have.

RADIATION. Opens orange yellow, changing to brilliant red florets; very large; a good bloomer, showing both colors until in full bloom.

SUNSET. Bright golden yellow of immense size, changing to orange and yellow, with brilliant red center.

PINK BEAUTY. Covered with flowers of silvery rose with center of soft yellow; a beautiful contrast.

THAIS. Blush, shading to cream.

ULTIMA. Magnificent pure golden yellow.

VIOLET KING. The buds and umbels extra large, of light yellow and pink; opens yellow and golden center, and as they open changing to pink and orange. When about onehalf in full bloom the first florets change to a beautiful violet maroon shade and show all of those colors until in full bloom.

\section{Plumbagos}

The Plumbagos are always satisfactory plants, either for pot culture or for the garden. They are constant bloomers, and their delicate and graceful flowers are very useful for cutting.

CAPENSIS. A well known favorite. Sky blue flowers. Price, 15 cents each.

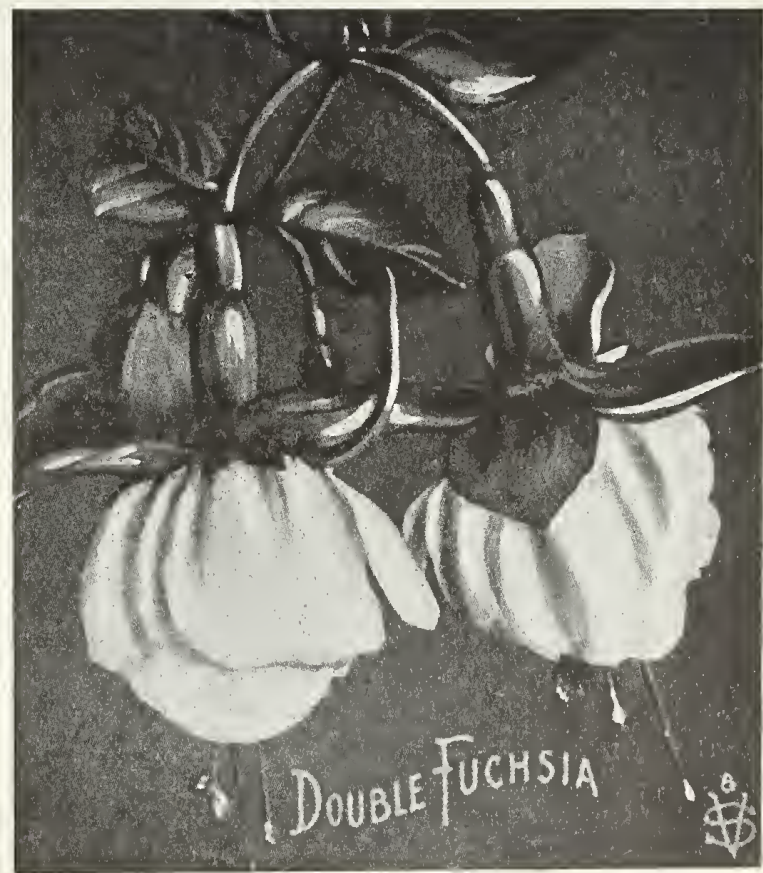




\section{Double and Single Petunias for Bedding}

\section{Giant Double Petunias}

Are as large as Hollyhocks: as double as double can be, with edges finely fringed; petals fluted and crinkled, intensifying and varying the colors with high lights and darks shadows, bringing out a richness and effect unmatched by crumpled velvet, which the flowers resemble. There is a variety of colors-selfs, blotched, veined, margined, etc.; in short, these double Petunias are unsurpassed by any other strain in the world. Price, 15 cents each; $\$ 1.50$ per dozen.

\section{Large Flowering Single Fringed Petunias}

The Single Petunia is one of the finest bedding plants for massing, mixed borders, or for vases. The brilliancy and variety of its colors, combined with the duration of its blooming period, renders it invaluable for garden decoration. Our collection is unsurpassed for brilliancy of color and size of bloom. It includes all the brightest shades of pink, purple, rose, white, etc. Price, 10 cents each $\$ 1.00$ per dozen.

\section{Dusty Miller}

Almost too well known for a description. This is the old Dusty Miller used for edging beds of Coleus, Geraniums, Cannas, etc Leaves silvery white. Price, 10 cents each; $\$ 1.00$ per dozen.

\section{Madagascar Periwinkle or Vinca}

This is a most attractive plant, blooming the entire summer season, forming a handsome shrub two feet in height and diameter. Color, rose, white, and white with crimson center. Price, 10 cents each; $\$ 1.00$ per dozen.

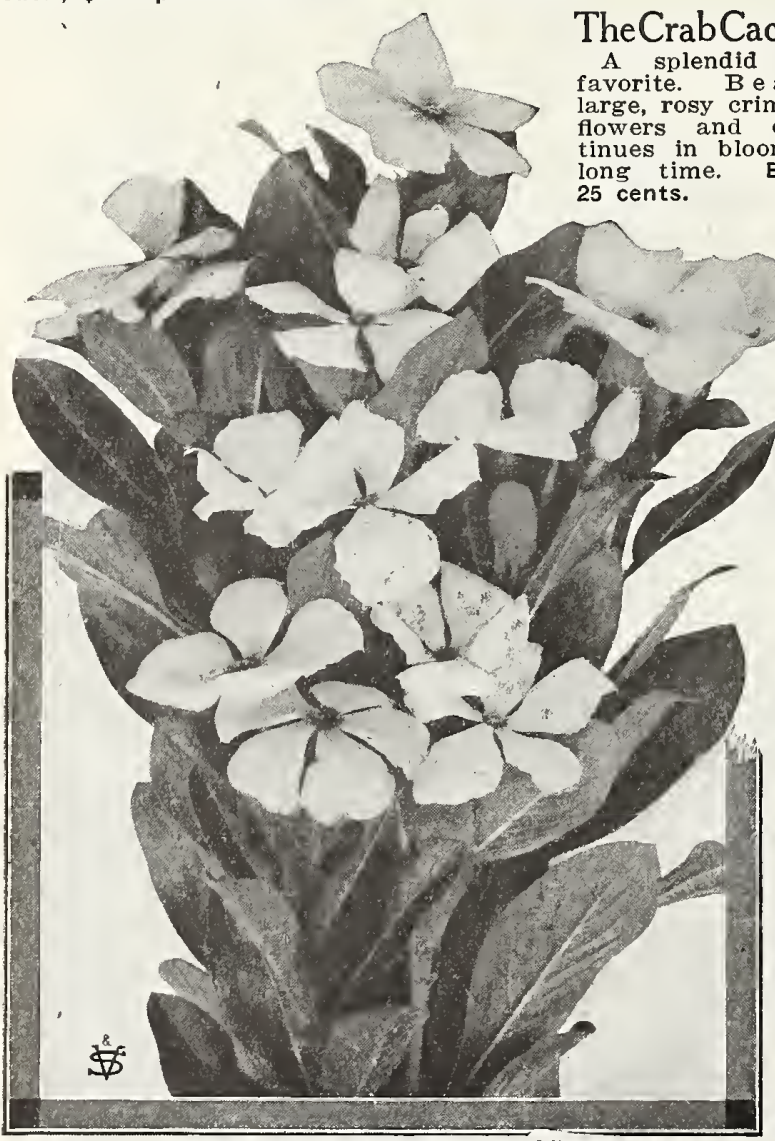

Madagascar Perlwinkle or VInca

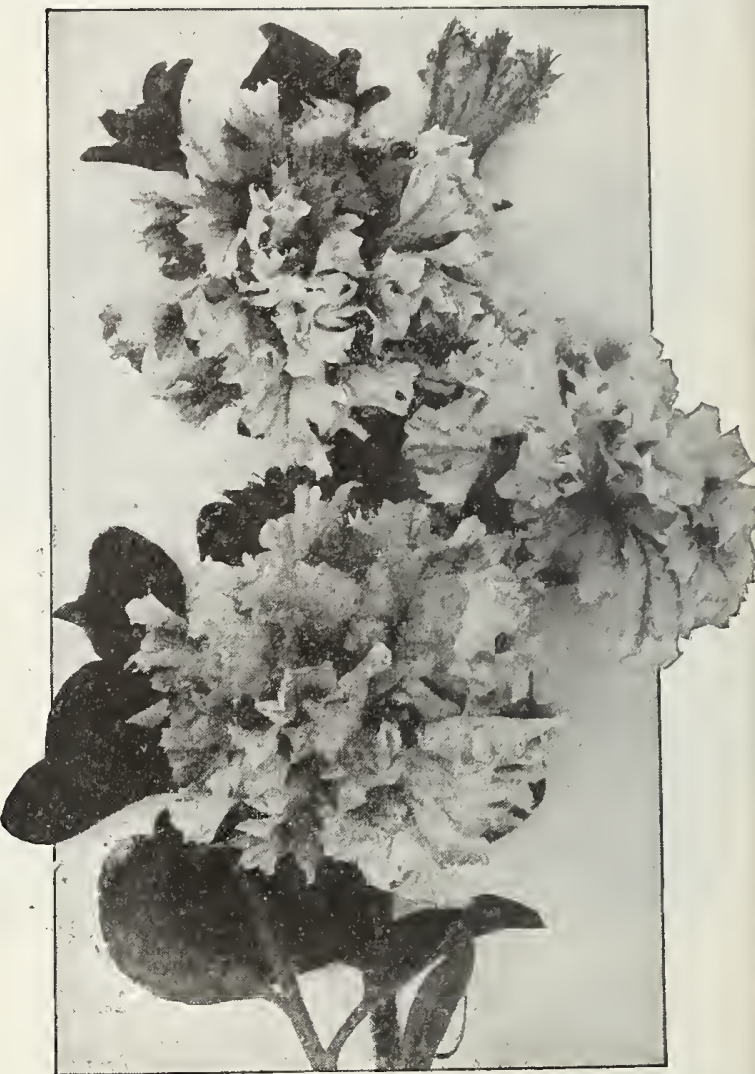

Double Fringed Petunias.

Feverfew, Little Gem

This variety surpasses the old variety in every respect. It is very dwarf, growing only from eight to twelve inches high. The flowers are larger and of more perfect form, and of the purest white and of free flowering habit, the plant being perfectly loaded with bloom. Price, 10 cents each; $\$ 1.00$ per dozen.

\section{English Daisies}

We can not praise too highly these pretty little spring blooming plants; charming little plants for edging and borders, among our earliest hardy spring flowering perennials. Price, 5 cents each; 50 cents per dozen.

SNOWBALL. A large and very double pure white Daisy.

LONGFELLOW. Best red variety; very double.

\section{Gynura Aurantiaca}

\section{Velvet Plant.}

Velvet Plant seems an appropriate name, the leaves being always taken as artificial. They and the stems are entirely covered with purple hairs; shining, glistening, reflecting many new colors. Any change of position appears to alter the color of the foliage. Price, 10 cents each.

\section{Trailing Houseleek}

Beautiful light green foliage, and yellow flowers in masses; much used for edging and carpeting bare spots, especially in cemeteries. Price, 10 cents each; $\$ 1.00$ per dozen. 


\section{NEW}

Grand, low-growing, bushy shrubs, hardy only in very sheltered locat,ions. Unequaled for porch and lawn decoration during summer. The blooms are immense, and come in such quantities as almost to cover the bush. On the approach of freezing weather, store in a light, cool cellar and water only sufficiently to keep the roots from drying up. If they start growth during the winter, move to cooler quarters. To make these Hydrangeas bloom blue, incorporate one-half pound of alum, broken into pieces about the size of a hickory-nut, with each bushel of soil.

Price for all, from 3 -inch pots, 25 cts. each; from 4-inch pots, $40 \mathrm{cts}$. each, postpaid; from 6 -inch pots, $60 \mathrm{cts}$. each, by express.

AVALANCHE. Magnificent, large, white; very free-flowering.

BOQUET ROSE. Large clusters of rosy amber changing to bright pink. Quite a distinct color and very beautiful.

LA LORRAINE. Large flowers; pale rose turning to bright pink.

MME. E. MOUILLERE. Large individual flowers of pure white which form massive heads. Won the Silver Medal at Boston, 1913.

MOUSSELINE. Mauve-rose with cream-colored center; often comes darker.

HORTENSIS. A well known favorite plant, producing large heads of pink flowers in great profusion. It thrives best in a shaded situation, with a plentiful supply of water.

\section{OFFER 60: ${ }^{-7}$ Any 3 of above, in 3-inch size, 60} cts; any 3 in 4-inch size, $\$ 1$, postpaid; or any 3 in largest size, $\$ 1.50$, by express.

\section{Sansevieria Zeylanica}

The leaves grow erect, 1 to 2 feet high, and are beautifully cross-barred with pure white and deep green.

Price, 15 cents and 20 cents each; extra size, 35 cents each.

\section{Umbrella Plant \\ (Cyperus Alternifollus.)}

Can easily be grown in a bowl or dish half-filled with rich soil, then filled with water. Price, 15 cents and 20 cents each.

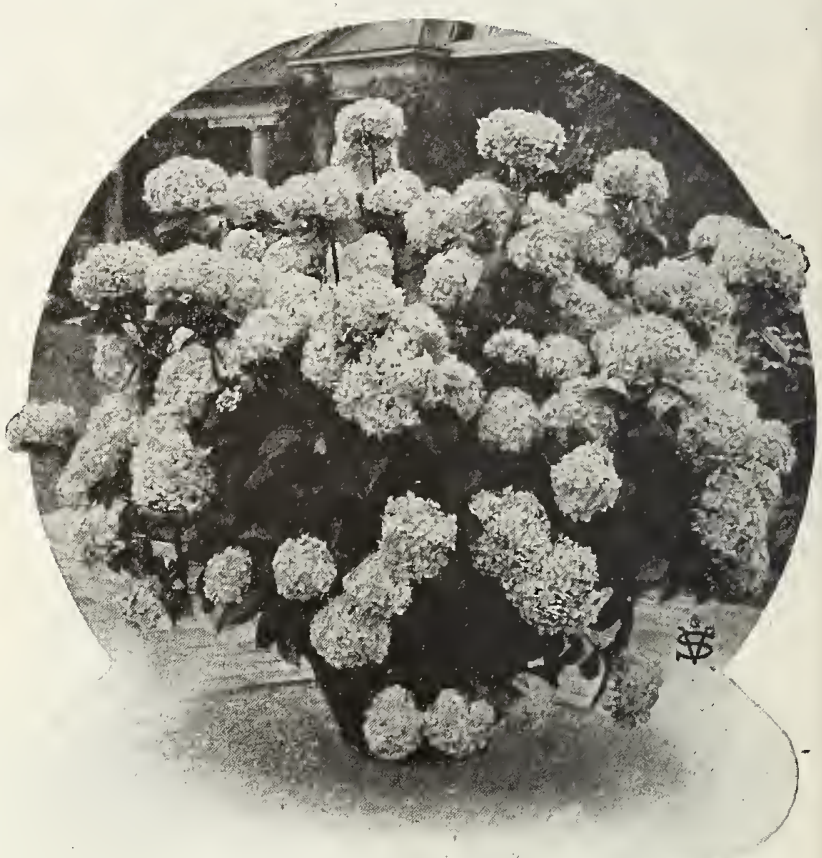

French Hydrangea.

Try a few along the base of your porch.

\section{Fragrant Hardy Garden Pinks}

Favorite of the Old-Fashloned Garden-the Fragrant Pinks. ABBOTTSFORD. A beautiful deep carmine, marbled with white. 10 cents each, three for 25 cents; 80 cents per dozen.

ELSIE. Bright rose, maroon center. 15 cents each.

HER MAJESTY. A grand variety; clear snow-white, elegantly fringed and delightfully clove-scented. 15 cents each; two for 25 cents; $\$ 1.50$ per dozen.

WHITE RESERVE. Everblooming. Snow-white; nicely fringed. Blooms from May to October. 15 cents each.

\section{GREAT “MAY-DAY” SALE \\ BETTER THAN EVER-FROM MAY 10 TO JUNE 10.}

CHOICE PLANTS AT GREATLY REDUCED PRICES. In growing so many varieties of plants in such large quantities we can not anticipate orders and grow just what will be required of each variety meet the demand. We always want to make sure we have enough of everything, and consequently we usually have a surplus of many of our choicest plants. Now, in order to close out our surplus stock at or near the end of the season we have decided to offer them at greatly reduced prices for thirty days after May 10, or from May 10 to June 10 . Persons ordering these collections will be surprised at the number and value of the plants they will contain; in fact, were we to foot them all up at catalogue prices, you would find you were getting them at less than half price. We reserve the right to select varieties, but will allow purchaser to state for what purpose intended, whether for pot culture or bedding; but unless otherwise ordered, the collection will contain plants for both pot culture and bedding. All orders received prior to May 10th will be forwarded promptly on that date.

One Hundred Choice Plants by Express for $\$ 3.00$. Thirtyfive Cholce Plants for $\$ 1.25$.

NOTE-Where patrons have no express office we wIIl send the offer of 35 plants by parcel post for $\$ 1.60$. 


\section{Bleeding Heart.}

These pretty spring bloomers with their graceful, drooping sprays of heartshaped pink and white flowers, are very ornamental, and bloom freely early in season. Price, 25 cents each.

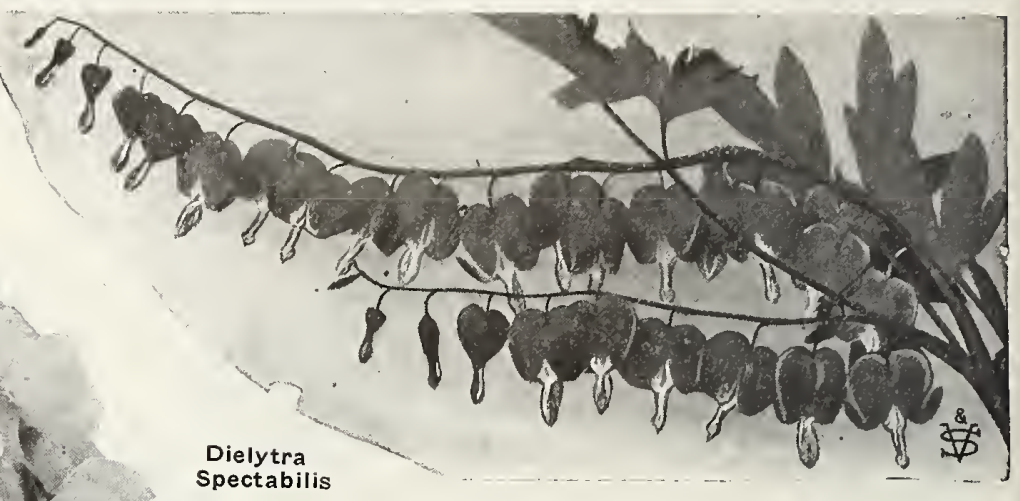

\section{Hollyhock}

Double. Its long spikes of short-stemmed rose-like flowers are particularly well suited to plant against the wall or fence, or in the background of a hardy perennial border. Five best colors-Yellow, Crimson, White, Maroon and Pink. Price, 15 cents each; one each of the four colors, 50 cents.

\section{Hibiscus-Mallow}

HARDY WHITE HIBISCUS (White Mallow.) Tall, freeflowering, perfectly hardy; color white, deep crimson center. Price, 30 cents each; 2 for 50 cents.

HARDY PINK HIBISCUS. (Pink Mallow.) Similar to the hardy white Hibiscus, but the flower is of a clear even pink, very striking. Price, 30 cents each; 2 for 50 cents.

HARDY CRIMSON HIBISCUS. (Crimson Mallow.) Immense striking deen rrimson flowers; nothing with as much merit has been in troduced in recent years. Price, 35 cents each.

\section{German Irises}

IRIS KING (New). Height, 30 inches, standard rich yellow; falls velvety plum edged yellow. A very striking variety.

GYPSY QUEEN. Standard old gold, shaded smoke pearl. Falls black maroon shaded and reticulated yellow; late bloomer.

MADAME CHEREAU. Height, 3 to 4 feet. Pure white, edges beautifully penciled azure, superb.

HECTOR. Height, 30 inches, standard soft clouded yellow; falls rich violet red; very showy.

CELESTE. Falls bright blue, uppers delicate grayish blue; all having a lavender effect.

DR. BERNICE. Height, 30 inches, standard coppery bronze; falls rich velvety plum; extra.

PURPLE KING. A deep rich purple very showy and effective in color scheme.

BLACK KNIGHT. Smoky purple.

Price of German Iris, 20c each; 6 for \$1, postpald.

\section{Japan Iris}

nd distinctive white eye EDMAND ROSTAND. Large flowers of reddish violet, with well defined star shaped white center.

FRAU ANTON BUCHNER. Dwarf; large flowered white. LA VAGUE. Immense conical heads; warm rosy lilac with emphatic carmine eye.

HENRI MURGER. Pure white; bright rosy eye.

MRS. JENKINS. The best tall early white for massing.

OBERGARTNER WITTIG. Bright magenta, with crim-

son-carmine eye; large flowers and truss; one of the best.

RYNDSTROM. Lively rose-pink, similar to shade of Paul

Neyron Rose. A grand variety.

R. P. STRUTHERS. Rosy-carmine, with claret-red eye, fine.

PANTHEON. Deep salmon rose; very fine.

PROF. SCHLIEMAN. Salmon rose; carmine eye.

SUNSHINE. Large, aniline-red, with crimson-red eye and light halo.
The magnificence of these new Iris surpasses description. The flowers are of enormous size, averaging eight to ten inches across, and of indescribable and charming hues and colors, varying like watered silk in the sunlight, the prevailing colors being white, crimson, rose, lilac, lavender, violet and blue; each flower usually representing several shades, while a golden yellow blotch, surrounded by a halo of blue or violet, at the base of the petals intensifles the wealth of the coloring. The Japan Iris is perfectly hardy and flowers in great profusion in July and August. Price, 15 cents each; four for 50 cents. 


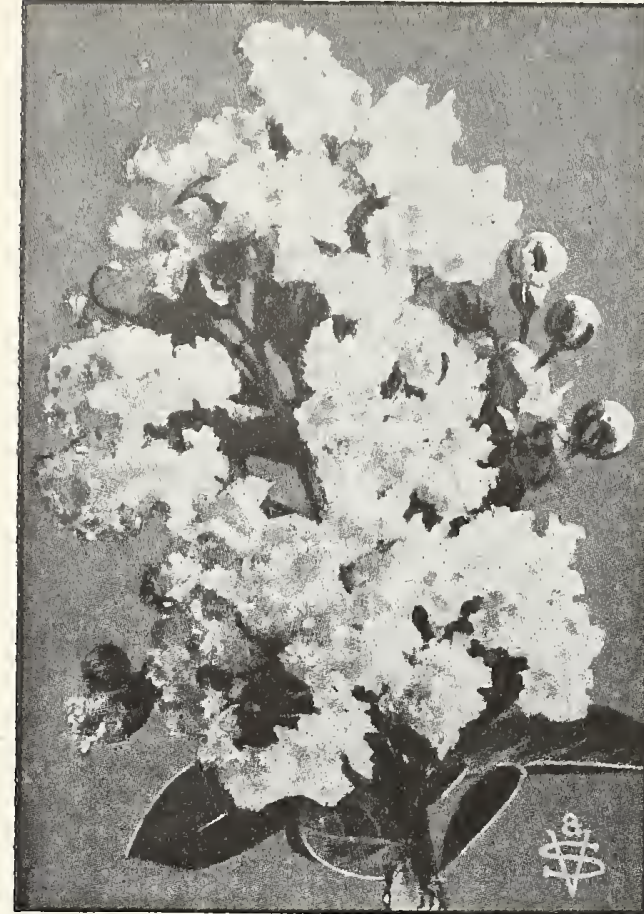

Beautiful White Flowered Crape Myrtle

By planting ornamental shrubbery you can rapidly increase the value of your property. The first cost is small and as the plants are perfectly hardy they require little care.

\section{Double Altheas-Rose of Sharon}

They grow neat and compact, and make nice shapely trees, four to six feet high. They bloom in August and September, when other flowers are scarce, and are literally covered with large, perfectly double flowers, like roses, of different brilliant and striking colors. Price, 35 cents each.

JOAN d'ARC. This is entirely new, and the finest Double White Althea ever introduced; grows regular and compact, and is literally covered with large, perfectly double pure white flowers, three inches across.

BANNER. Large double flowers; clear bright pink.

LUCY. Large, double rose-red flowers; very handsome.

DOUBLE PURPLE. Double flowers; reddish purple.

TOTUS ALBUS. Finest single pure white.

\section{Buddleia}

VARIABILIS VEITCHIANA. (Butterfly Shrub, or Summer Lilac). Violet-mauve flowers, borne in spikes 12 to 15 inches long; blooms from July till frost. Should have winter protection. 20 cents; two-year, $35 \mathrm{c}$.

\section{Calycanthus}

(Sweet Scented Shrub). Flowers chocolate color, very double and deliciously fragrant; remains in bloom for a long time; very desirable. Price, 35 cents each.

\section{Crape Myrtle-Lagerstroemia}

INDICA. Very beautiful shrub. A profuse and continuous bloomer; flowers bright rosy pink, curiously crimped petals. Prlce, 35 cents each.

NEW CRIMSON. Vivid crimson. Price, 35 cents each.

WHITE. Flowers purest white and beautiful; of recent introduction and a general favorite where known; of vigorous and symmetrical growth. Price, 40 cents each.

\section{Deutzias}

PRIDE OF ROCHESTER. Grows strong and upright, four to six feet high; flowers very double and full; pure white, tinged with blush.

CRENATA. Single. Pure white flowers.

FLORA PLENA ROSA. Flowers double white tinged with pink, in racemes four or five inches long; one of our finest hardy shrubs. Price, 40 cents each.

\section{Forsythia-Golden Bells}

This is one of the most useful shrubs for the permanent decoration of buildings. It can be easily trained over a wall, fence or tree trunk. The flowers are bell-shaped, of a clear yellow, and there are no green leaves. It is the earliest shrub to bloom. Price, nice strong plants, 25 cents each.

\section{Rhus-Sumach}

PURPLE FRINGE. (Smoke Tree).. A round-headed low tree. In July and August covered with reddish seed-vessels like purple mist. Very attractive. Price, 50 cents each.

\section{Chionanthus-White Fringe}

Early in June it sends out large numbers of showy, pure white feathery-like flowers. Very fragrant and extremely pretty against the large green foliage. Price, large field. grown plants, 50 cents each.

\section{Common Snowball}

A grand hardy shrub with handsome showy flowers produced in large globular clusters. Is an old-time favorite. Price, large field-grown plants, 40 cents each; three for $\$ 1.00$.

\section{Japanese Snowball}

Erect and compact, 6 to 8 feet high. flowering in June with large white blooms. Price, large field-grown plants, 40 cents each; three for $\$ 1.00$.

\section{Mock Orange-Philadelphus}

SINGLE. Creamy white, cupped flowers; intensely fragrant. Two-year, 40 cents each, by express.

DOUBLE. Bears quantities of double white, fragrant flowers. Two-year, 40 cents, by express.

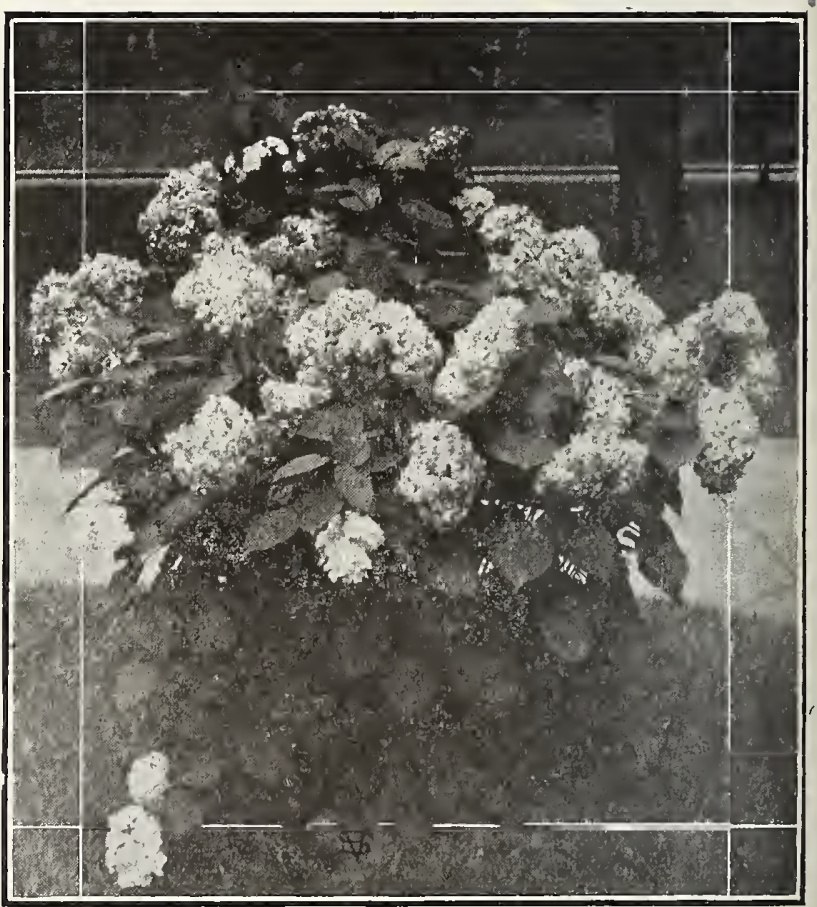

"Hills of Snow," or Snowball Hydrangea. 


\section{WEIGELIA}

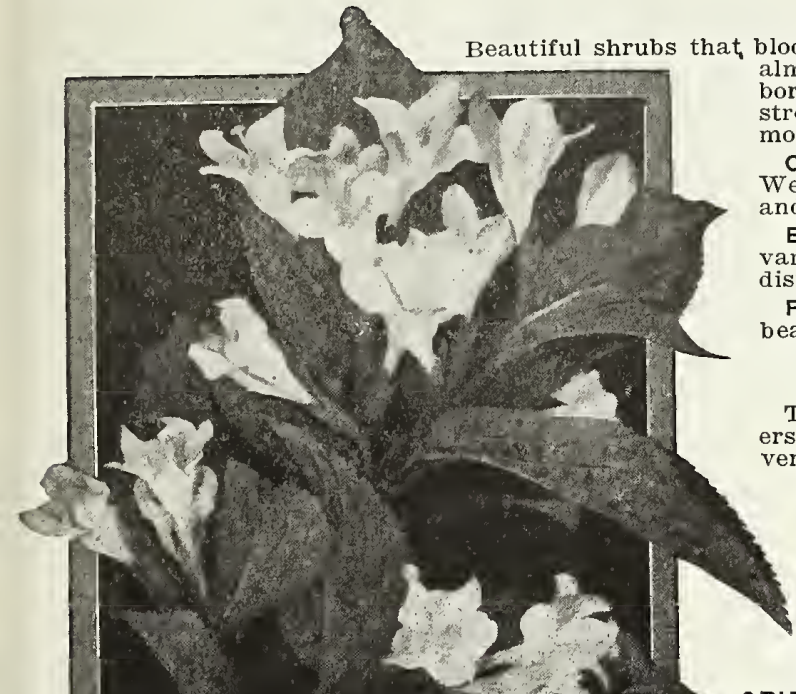

in April. The tlowers are produc They are very desirable for the the lawn. We strongly recommend them as good shrubs to set out. One of ten most popular shrubs.

CANDIDA. This is the very best of all the white-flowered Weigelias; a strong, upright, erect grower; flowers are pure white, and produced in great profusion.

EVA RATHKE. We certainly have a grand acquisition in this variety, that is at once a remarkably free bloomer and entirely distinct color, being a rich reddish purple.

ROSEA VARIEGATA. A variety bearing rose colored flowers; beautiful variegated foliage. Price, 40 cents each.

\section{Lonicera-Bush Honeysuckle}

The upright Honeysuckles have bright and pretty fragrant flowers followed by the showy berries that last through the fall. Make very desirable and attractive hedges. Price, 40 cents each.

\section{Spirea-The Spireas}

SPIREA ANTHONY WATERER. A fine, hardy, perpetual blooming shrub, particularly desirable for the door yard and lawn, or wherever fine, hardy flowering shrubs are wanted. Make nice round bushes only 15 to 18 inches high; begins to bloom almost as soon as planted, continuing all summer and fall; rich, rosy, red flowers. If lifted and taken indoors will bloom all winter. Strong plants that will bloom this season, two-year, $35 \mathrm{c}$ each.

SPIREA VAN HOUTTEI. The grandest of all white Spireas; it is a beautiful ornament for the lawn at any season, but when in flower it is a complete fountain of white bloom, the foliage hardly showing. Clusters of twenty to thirty flat white florets make up the raceme, and are set close along the drooping stems. Price, 35 cents each.

\section{Spirea Colossa Alba}

Pure white flowered, dware growing variety; very good for edging beds of taller growing shrubs. Price, 40 cents each.

\section{Pink Flowering Almond}

\section{Hydrangea}

Weigelia.

One of the best and most reliable shrubs, giving a great abundance snowy white flowers in Autumn when blossoms are few. Hardy, grows well in any rich moist soil. To secure large clusters of blosof the previous year to one to three pairs of buds, depending upon the quantity of blossoms desired.

PANICULATA GRANDIFLORA. Blooms in August, September and October. The flowers are rich creamy white, changing to pink, and borne in immense clusters, more than a foot long; it blooms in August, the first and every succeeding year; continues in bloom for months. Hardy, no trouble to grow. Prices for strong plants that will bloom this season, two-year size, 40 cents.

ARBORENSCENS GRANDIFLORA. (Hills of Snow) Comes into bloom in many places as early as July 4 . Makes a plant much like the common. Hydrangea, but blooms with purest snow-white flowers. 40 cents.

\section{Lilac}

PURPLE. Grand new variety; flowers deep purple; fragrant; blooms second year. Price, 40 cents each.

White. Rare and beautiful. Very sweet. Price, $40 \mathrm{c}$ each.

\section{Evergreens}

GOLDEN ARBOR VITAE. (Biota Aurea.) This is a handsome and compact Arbor Vitae of beautiful golden color. Price, 50 cents each. Larger, $\$ 1.00$ each.

PYRAMIDAL GOLDEN ARBOR VITAE. In every respect the same as above, except that the general form of the tree is taller and cone-shaped. Price, 50c each. Larger, $\$ 1.00$ each. ROSEDALE ARBOR VITAE. An exceedingly handsome evergreen with light bluish green foliage, turning to stee blue in winter. Price, 50 cents each

BIOTA AUREA NANA. Of very dwarf and compact habit: a perfect gem for small gardens or cemetery lots. It far surpasses the old Biota Aurea where a very dwarf tree is desired. Price, 50 cents each.
(Prunus Sinensis)-Flowers double, rose color, one of the first to flower in the spring. Very showy. Price, by express. $50 \mathrm{c} \mathrm{each}$.

\section{White Flowering Almond}

Same as pink variety in growth and habit, but bearing white flowers. They should be planted together. Price, by express, 50c each.

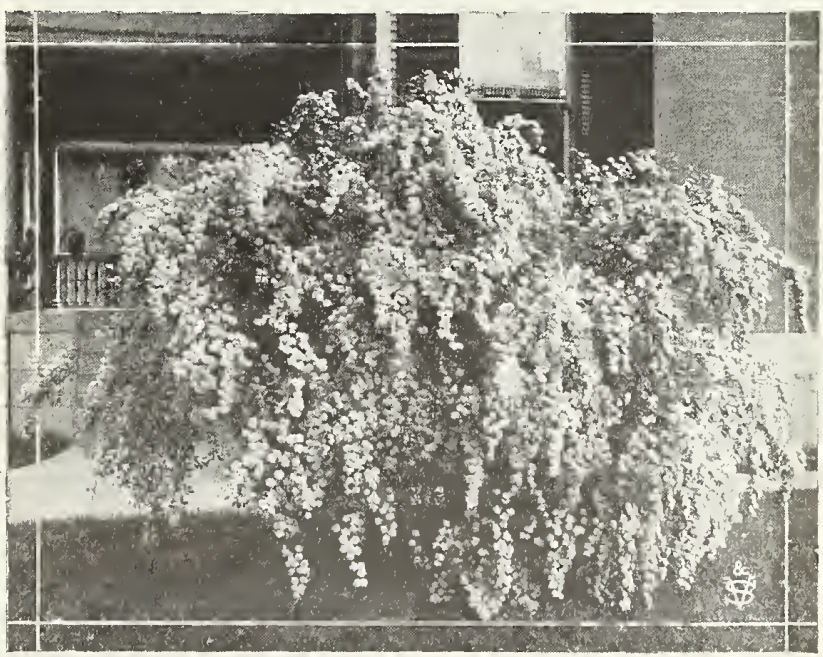

Spirea Van Houttei. 


\section{Beautiful Hardy Climbing Vines \\ Hop Vines}

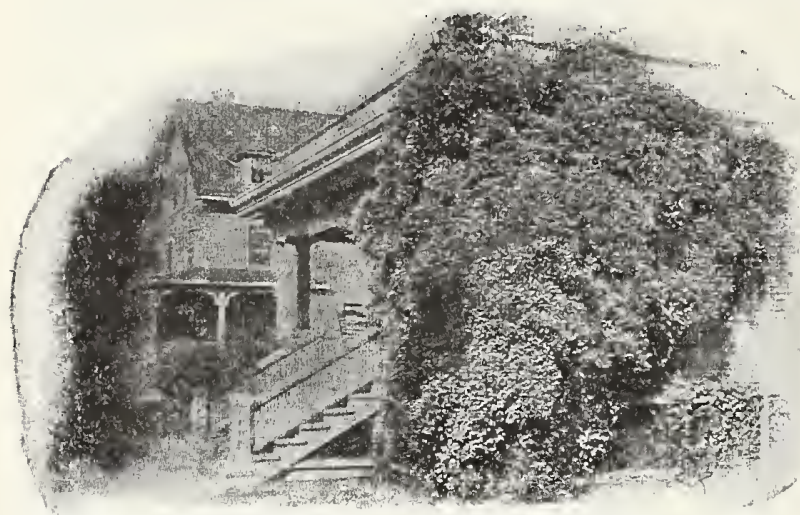

The Hardy Sweet Scented Clematis Paniculata.

\section{Clematis Paniculata}

Flowers are rich, creamy white, star-shaped, and borne in beautiful clusters, completely covering the vine with beautiful star-shaped blossoms, exceedingly fragrant; the sweetest of all Clematis, and one of the hardiest and easiest to grow. Price, good strong plants, 30 cents each; two for 50 cents.

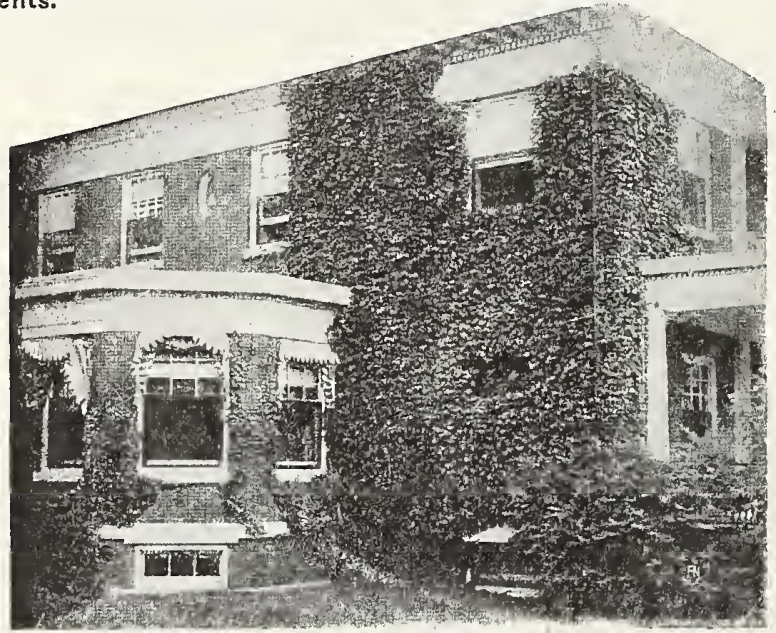

Boston Ivy second year after planting.

Vines are indispensable on every home.

\section{Boston Ivy}

A beautiful hardy climbing plant, for covering walls, as it clings firmly to the smoothest surface, covering it smoothly with overlapping leaves, which form a perfect mass of follage. The color is a fresh, deep green in summer, changing to the brightest shade of crimson and yellow in autumn. It is quite hardy, and becomes more popular every year. Prlce, strong plants, 35 cents each; 2 for 60 cents.

\section{Aristolochia Sipho (Dutchman's}

A vigorous and rapid growing elimber, bearing singular brownish-colored flowers, resembling in shape a pipe. Its flowers, however, are of little value compared to its lightgreen leaves, which are of very large size, and retain their color from early spring to late fall; perfectly hardy. Price, strong plants, 60 cents each.
GREEN-LEAVED. A useful climber for covering unsightly places. It is a rapid grower and bears a profusion of seedpods suitable for many domestic purposes. Price, 25 cents each; $\$ 2.50$ per dozen.

\section{Bignonia (Trumpet)}

For covering unsightly-places, stumps, rockwork, or wherever a showy-flowering vine is desired, the Bignonias 'will be found very useful. The flowers are large, attractive and borne profusely when the plants attain a fair size.

RADICANS. Dark red, orange throat, free blooming and very hardy. Price, 25 cents each; $\$ 2.50$ per dozen.

\section{Antigonon Leptopus (Mountain)}

A lovely climber from Central Mexico with beautiful rosecolored flowers in racemes two feet long. The profusion of bloom is such as to give the resemblance of Roses at, a distance, hence the Mexican name "Rosa de Montana," or "Mountain Rose." Described by its discoverer as the most beautiful climber he had ever beheld. Price, 30 cents each; 4 for $\$ 1.00$.

\section{Honeysuckles}

GOLDEN JAPANESE, Flowers creamy white, fragrant, scarcely more beautiful than the golden netted leaves.

HALL'S. Even in cold climates this vine holds its-leaves until January; in the South it is evergreen. It is the freest growing and blooming sort of all, showing fragrant flowers of buff and white from May until December.

SCARLET TRUMPET. The most beautiful and brilliant of all Honeysuckles; is also the hardiest and most vigorous. The stems often twine about second story windows, wreathing them in early spring with large, inodorous clusters of long, tubular scarlet flowers. The foliage is bluish green, the berries scarlet. Also called Coral Hon eysuckle. Price, strong plants, 25 cents each; $\$ 2.50$ per dozen.

Virginia Creeper .ampelopsis quinguefolia

Woodbine-A well known hardy, rapid, high climbing vine. clinging to walls, trellises and trunks of trees. The foliage fades in the autumn and as sumes brilliant and gorgeous shades of yellow, crimson and scarlet in the fall. Strong plants, $40 \mathrm{c}$; 3 for $\$ 1.00$.

Wistaria-chINESE BLUE.

There is no vine more decorative in its effect than the Wistaria. Its long, twining branches bearing great sprays of light purple and blue flowers in $\mathrm{May}$ sway with every passing breeze. For $\mathrm{p}$ or $\mathrm{ch}$ decoration without too much shade they have no superior. Price, 30 cents each.

CHINESE WHITE

The white variety, in all respects same as purple, except in color. Prlce, 40c each.

English Ivy

One of the most beautiful vines for walls, pillars, tree trunks, ground covers, etc., that can be used. The Ivy of literature and old European ruins. Prlce, strong plants, $15 \mathrm{c}$ each; $\$ 1.50$ per dozen; extra strong plants, 25 cents each; $\$ 2.50$

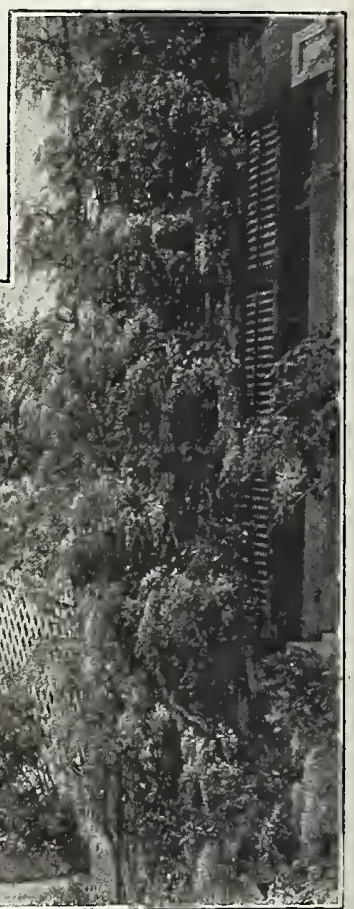
if desired.
Wistarias will climb to your roof, 


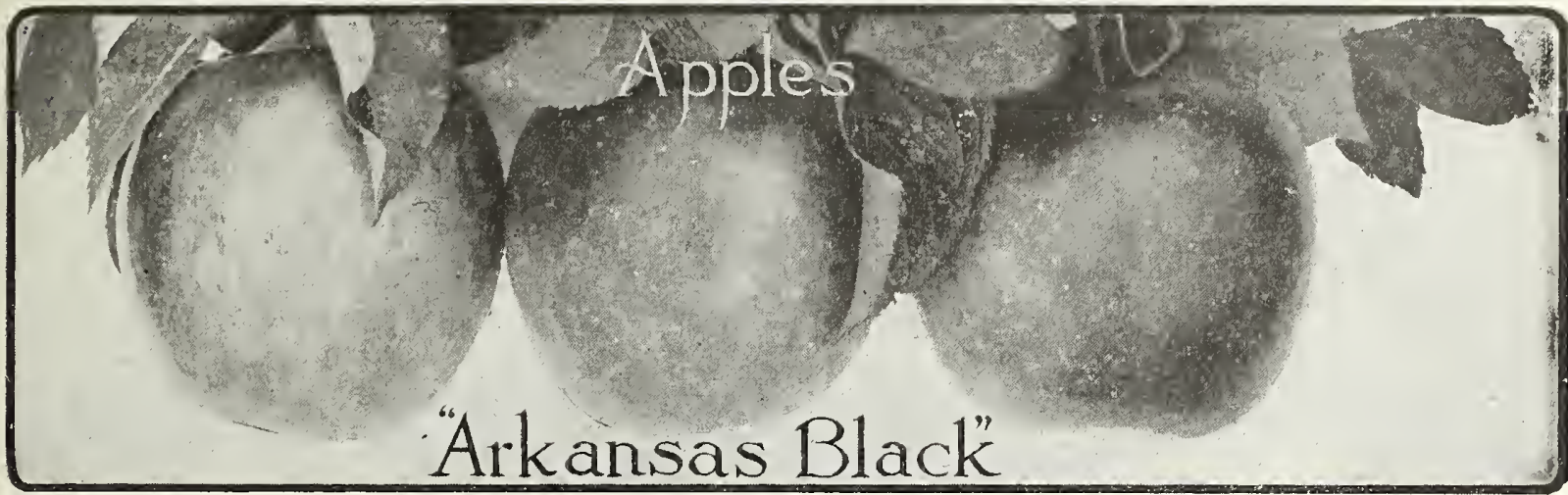

The universal domestic fruit. Apples are pre-eminently the fruit of commerce, more widely and more extensively grown than any other fruit. Many sections of the Southwest are leading in the production of apples. Our list comprises the varieties recognized as standard. Great care has been exercised in selection and all trees are healthy and vigorous and free from disease.

Apples, 50 cents each; $\$ 5.00$ per dozer.

DUCHESS OF OLDENBURG. Tree a strong grower, young and abundant bearer. Fruit large, yellow streaked red, rich sub-acid flavor, juicy and good.

YELLOW TRANSPARENT. One of the most desirable early apples in cultivation. Early bearer, frequently producing fine fruit on 2-year trees in nursery rows. Good grower and hardy, fruit pale yellow, good size and good quality; skin clear white at first, becoming a beautiful pale yellow when fully matured. Ripens before Early Harvest.

EARLY HARVEST. Medium to large; pale yellow; tender with a mild, fine flavor. An erect grower and a good bearer; excellent for orchard and garden; one of the first to ripen.

RED JUNE. Medium conical; deep red; juicy. Very productive.

RED ASTRACHAN. Large, beautiful deep crimson, overspread with a thick bloom; juicy, rich, acid and productive. One of the best of the summer apples.

SUMMER QUEEN. Large; yellow, marked with red and orange; flesh tender, crisp, juicy and highly flavored. Tree vigorous and yielding heavily. Nothing finer among the early fall varieties.

HORSE. Large; green; acid. Good for cooking and drying. Known everywhere. A very productive variety.

MAIDEN'S BLUSH. Rather large, smooth, with a fine evenly shaded red cheek or blush, on a clear, pale yellow ground; flesh white, tender, sprightly with a pleasant, subacid flavor; bears large crops. Valuable market sort.

YELLOW BELLFLOWER. Beautiful, and excellent for any purpose. Yellow, tinged with red; oblong, crisp and juicy, with an aromatic flavor.

JONATHAN. Medium, pale yellow, nearly covered with brilliant stripes of lively red; flesh white, juicy, spicy, subacid, fine grained, rich. Tree a slender grower, very productive. An excellent fruit and favorite market variety.

STALMAN'S WINESAP. An improvement over the Winesap. The fruit is large, and it is much more prolific than the Winesap, which it resembles in color and flavor. A fine apple.

KING DAVID. Fruit a beautiful deep red with occasional blotches of yellow. The tree is a vigorous grower, very productive, and produces fruit when quite young.

MAMMOTH BLACK TWIG. A large, dark red apple. Tree is a very good grower and very productive. A good market variety.

\section{Crab Apple}

TRANSCENDENT CRAB-APPLE. A large, superior variety; golden-yellow with rich crimson. Flesh crisp, juicy and aromatic, making excellent jelly and preserves. Small core. Tree wonderfully vigorous and productive. Price, 50 cents each.

\section{Quinces}

Price, 3 to 4 feet, 50 cents each.

BOURGEAT. A new golden prolific variety of best quality, yielding immense crops, fruiting at three and four years. Fruit of largest size round rich golden colot and very

作

MEECH. A vigorous grower and immensely productive; fruit is large, lively orange-yellow, and has good cooking qualities.
DELICIOUS. A remarkable variety introduced in the West several years ago, where it is being largely planted and rapidly taking first rank both for commercial and home orchards. No new variety has ever so quickly gained popularity in so many different apple sections. Fruit large, nearly covered with brilliant dark red; flesh fine grained, crisp and melting, juicy, with a delightful aroma; of very highest quality. A splendid keeper and shipper. Tree one of the hardiest, a vigorous grower, with good foliage. A regular annual bearer.

ARKANSAS BLACK. A fair-sized, winter, market apple. Color beautiful maroon. Flesh firm and fine-grained. Juicy and keeps well. Tree is a vigorous grower, hardy and productive: comes into bearing quite young.

GRIMES GOLDEN. Greatly prized as a hardy variety, golden yellow, with small dots; flesh yellow, juicy, tender, crisp, rich, sprightly sub-acid, with a fine aroma.

\section{EARLY PLANTING IN- SURES CERTAIN SUCCESS.}

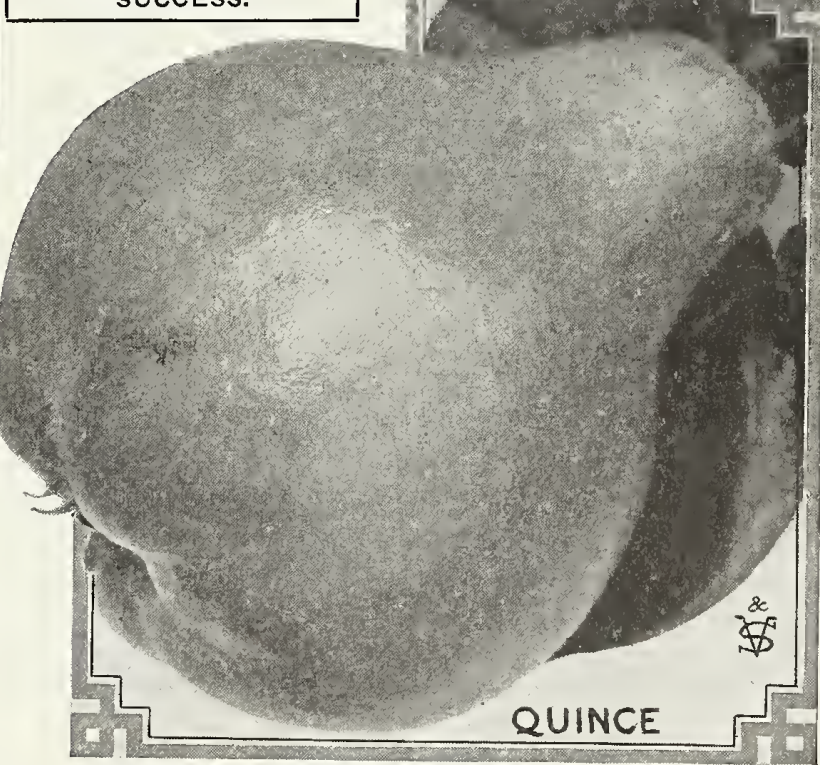
producing annual crops. Medium, roundish oblate; rich 


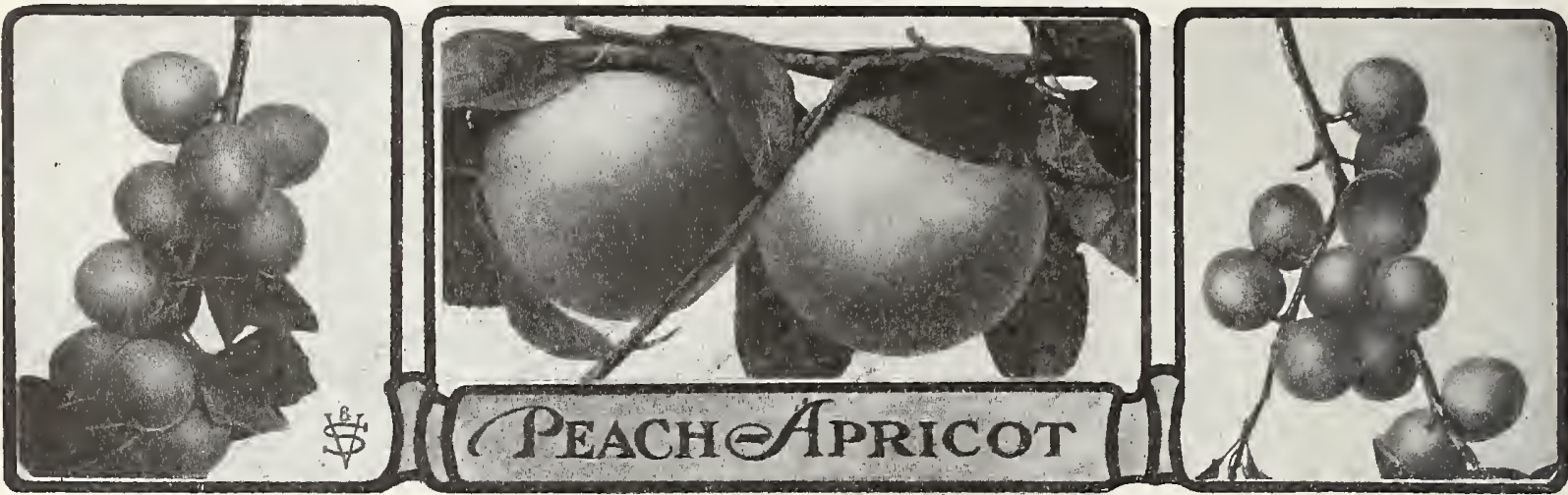

Moorpark Apricot.

Elberta Peaches.

Royal Apricot.

Price, 40 cents each; $\$ 4.00$ per dozen.

SNEED. Medium; creamy white, with carmine mottling; flesh greenish white; juicy; semi-cling; quality fair.

ADMIRAL DEWEY. Ripens with the Triumph; better form and color, stronger grower, hardy and productive.

GREENSBORO. The largest and most beautiful colored of all the early varieties. Double the size of Alexander, ripening at the same time. Flesh white, juicy and good.

MAMIE ROSS. Creamy white, almost covered with delicate carmine. Mamie Ross is unquestionably the best of this valuable hardy group.

CRAWFORD EARLY IMPROVED. This strain far better than old Crawford Early and hardier. Large, yellow, bright red cheek. Succeeds best in clay soils.

MOUNTAIN ROSE. White, nearly covered with light and dark rich red. Splendid quality; popular.

CARMAN. Large; creamy white, with deep blush; skin tough, but flesh very tender and of fine flavor; prolific bearer. A most profitable and popular variety. Ripens June 20 to July 1.

CHAMPION. Large; skin creamy white, with red cheek; flesh rich and juicy. Ripens middle to last of July.

BELLE (Belle of Georgia). Very large; skin white, with red cheek; flesh, white, firm, and of excellent flavor: very prolific; excellent shipper. Tree a rapid grower. July 5 to 20 .

\section{Figs}

The below named sorts succeed well here. Price, two to three feet size, 50 cents each; ten for $\$ 5.00$.

BROWN TURKEY. Medium brown; sweet and excellent; very prolific and reliable.

BRUNSWICK. Very large violet; quality good, and productive.

CELESTIAL. Makes large trees; hardy farther north than most other varieties. Small, pale-violet fruit, fine flavored, very early, commencing to ripen in June and continuing two months.

\section{Apricots}

Price, 50 cents each.

EARLY GOLDEN. Medium size, pale yellow, vigorous and prolific. The tree is a very strong grower, hardy, vigorous, and productive. Bears about the fourth year. Blooms late. One of the newer and most promising apricots.

MOORPARK. Very large, orange color, with a deep orange-red cheek. Flesh firm, quite juicy, rich, luscious flavor. The most delicious apricot grown. A vigorous grower, hardy, moderately productive. Bears fourth year. One of the most popular varieties because of its great size and superior qulaity.

ROYAL. Large, roundish, oval, light yellowish orange color. Very rich, highly flavored, which makes it especially valued for drying and canning. A commercial favorite in the orchards.

\section{Mulberries}

HICK'S EVERBEARING. Large, black, sweet, very proliflc; fruit several months. Ripe in June, July and August. Price, 50 cents each.
CAPT. EDE. Large, yellow, excellent quality. Tree hardy both in bud and blossom. Said to be an improved Elberta, ripening ten days earlier.

ELBERTA. The best known and most popular of all peaches and the standard market, sort. Large, yellow with beautiful blush; not of highest quality, but tender and good.

Rank, vigorous grower.
MATHEW'S BEAUTY. Skin golden yellow, streaked with red; flesh yellow, firm, of excellent quality, equal to Elberta in market quantities; ripens later.

OLD MIXON CLING. Large, yellow with red cheek; juicy, high quality.

CRAWFORD LATE IMPROVED. Large, very handsome, fairly hardy. Later, surer bearer, larger, finer quality and hardier than the old strain.

LEMON CLING. Large, lemon-shaped; beautiful light yellow, blush red, fine canning and preserving peach.

HEATH LATE WHITE. Large; oval; skin creamy white; very seldom with any red; flesh pure white to the stone: juicy and sweet, with good aroma. Very popular for preserving. Ripens beginning of September.

LATE ELBERTA. Identical with Elberta in size, color, shape and quality, but ripens a month later.

HENRIETTA. Fine cling; large size; skin deep yellow shaded brownish red in the sun; flesh firm and juicy.

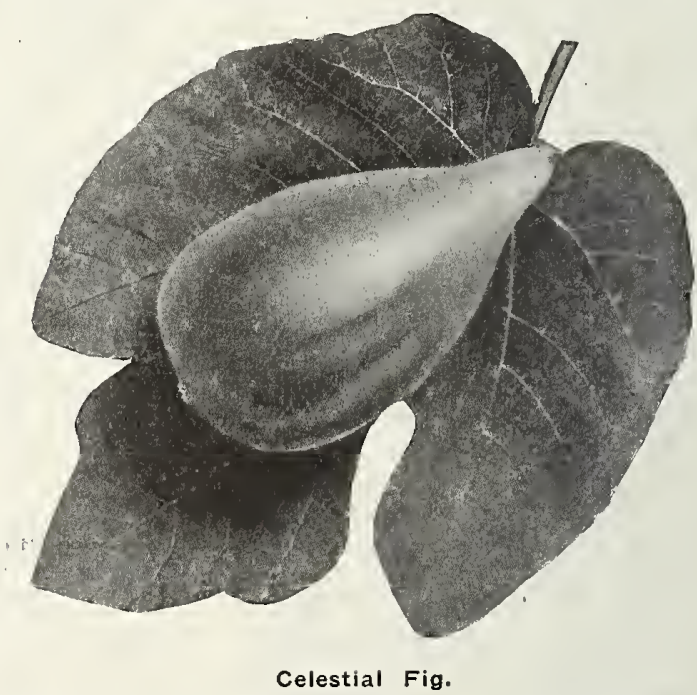

Orders for Fruit Trees received too late in spring for planting will be sent the following fall. 


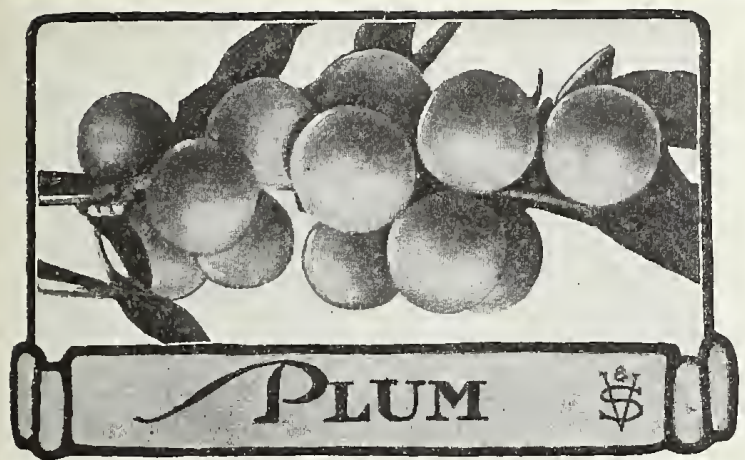

The ability of the Plum to adapt itself to various conditions of soil and climate makes it one of our most valuable fruits. When properly.grown and well ripened on the tree the Plum is one of the most delicious fruits. Price, 50 cents each; $\$ 5.00$ per dozen.

ABUNDANCE (Botan). One of the oldest and best known Japanese varieties; hardy and productive. Fruit large, lemon yellow, with heavy bloom; good quality. August.

BURBANK. The best and most profitable among growers for market; ripens 10 to 14 days after Abundance. Tree hardy, sprawling vigorous grower, unequaled in productiveness; bears young. Fruit large, excellent quality; cherry red with lilac bloom.

RED JUNE. Recommended as "by all odds the best Japanese plum, ripening before Abundance." One of the vigorous, upright growers; productive: fair size, vermilion red pleasant quality. Ripens a week before Abundance. August.

SATSUMA (Blood). Large, globular, with sharp point. Color, purple and red with blue bloom, flesh firm, juicy, dark red or blood color, fine quality; pit very small. Hardy and vigorous grower. August.

WICKSON. Very large; heart-shaped; deep red; flesh firm, juicy and of fine flavor; pit small. Excellent for shipment. Tree of vigorous, symmetrical growth, bearing well. Early August.

WILD GOOSE IMPROVED. Bright red, very sweet and juicy. This strain is superior to old Wild Goose; fruit largest; tree healthier.

12 ASSORTED FRUIT TREES.

These are our largest 4 to 5 -foot trees, $\$ 4.00$.

Apple.

1 Yellow Transparent.

1 Maiden's Blush.

1 Delicious.

1 Arkansas Black.

1 Satsuma. Plum.

1 Red June.

Largest size, 4 to 5 -foot trees.

1 Elberta.

1 Bartlett
Peach.

1 Greensboro.

1 Belle of Georgia.

1 Late Elberta. Pear.

cherry.

1 Montmorency.

\section{Small Fruits}

Raspberries, Blackberries and Grapes.

RASPBERRIES. $10 \mathrm{st}$. Regis: The only successful everbearing red Raspberry, brilliant crimson, large, juicy. Old canes bear until August, when canes of this season's growth produce fruit. Hardy, vigorous.

BLACKBERRIES. 10 Early Harvest. Early, large, long berries; flesh juicy, good flavor; productive.

GRAPES. 1 Moore Early: Very early; deep, purplish black; ripens two weeks ahead of Concord.

1 Niagara: Mid-season; green, larger than Concord; vigorous, productive. A splendid small fruit collection, $\$ 2.00$.

Gentlemen: I have just received the plants and trees ordered from you and all satisfactory. Thanking you very much for the extra plants and trees. MRS. A. O. MURDOCK, Shelbyville, Tenn.

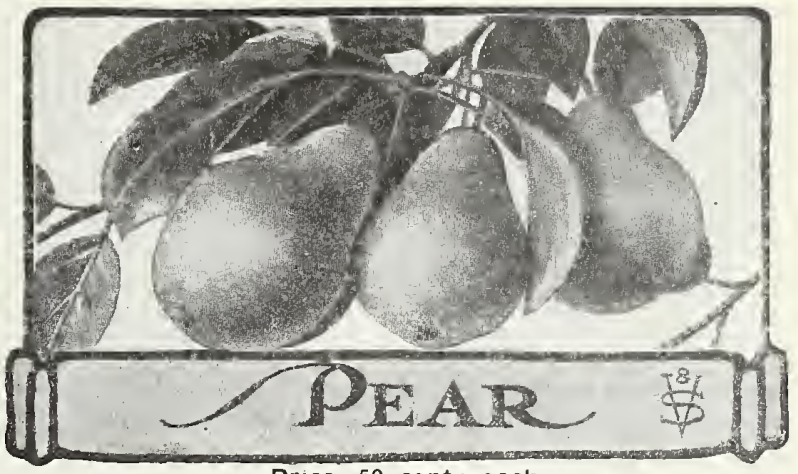

Price, 50 cents each.

KEIFFER. Its large size, handsome appearance and remarkable keeping and shipping qualities make it exceedingly profitable for market. October and November.

LAWRENCE. Medium to large, golden yellow, melting with rich aromatic flavor. Tree moderate grower, good bearer. September to October.

BARTLETT. Clear lemon yellow with soft blush. Buttery juicy and highly flavored. A great bearer. One of the favorite varieties.

SECKEL. Small, rich yellowish brown and red. Flesh rich, fine flavor. August.

DUCHESSE. Very large, greenish yellow, spotted with russet. Flesh white, buttery, with rich, excellent flavor.

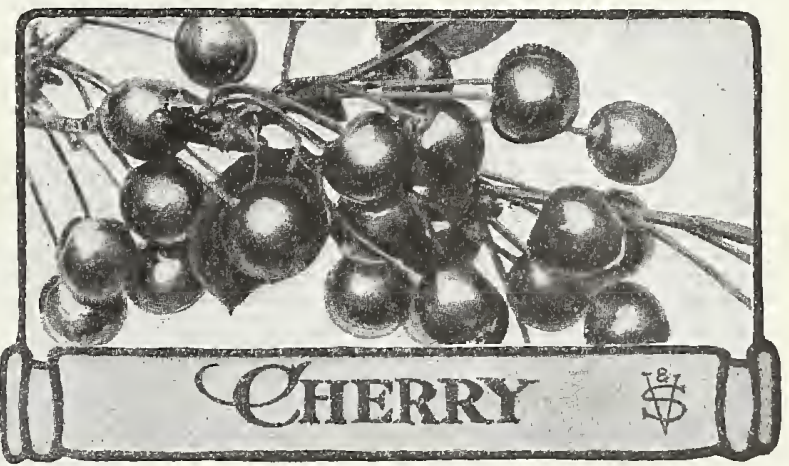

Thrive in nearly all sections, preferring an elevated naturally light, dry, retentive soil. The sour kinds need more moisture and will grow in heavier land. They bear better when associated with another variety.

Price, 50 cents each.

BLACK TARTARIAN. Deep, purplish-black; very large, fine, sweet, rich flavor. A favorite. Beautiful tree, strong, upright, and bearing well. June.

EARLY RICHMOND. A cherry of medium size; dark red melting and jjuicy; unsurpassed for cooking purposes. Trees small and bushy, the hardiest of all varieties; uninjured by the coldest winters, and very productive in almost any locality. May and June.

ENGLISH MORELLO. Medium to large; deep red. Excellent for cooking; tender, acid and juicy. Tree of comparatively slow growth, dwarfish, forming a round, compact head; adapted to nearly all localities; very productive. July and August.

MONTMORENCY. Red, rich, acid, very hardy and productive. June.

GOVERNOR WOOD. Large, heart-shaped; light yellow, marbled light red, juicy, sweet, rich. An, old variety and still a favorite.

Gentlemen: The Roses and Grape Vines came a few days ago and $I$ want to thank you so much for the generous lot of extras you added to the order. Yours very truly, MRS. P. W. IONS, San Angelo, Texas. 


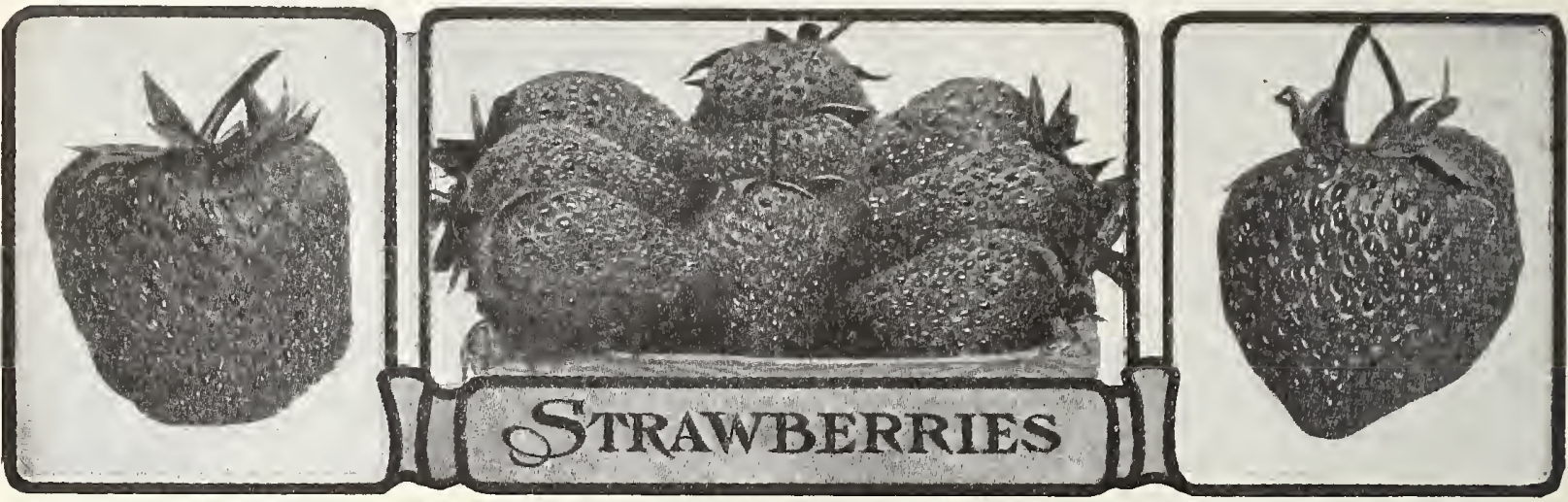

Lovers of Strawberries consider them the most delicious of earth's products, and it is certain that the big, juicy, firm, rich red berries offered in this collection are fit for a royal feast. After long trials and careful comparison we have selected from all the known sorts the varieties offered below as the most desirable and luscious Strawberries for the home or market garden. They are all uniformly large, handsome, rlch colored and delightfully flavored. They make an ideal collection for the family garden. Price, postpaid, by mall, 25 for 60 cents; 50 for $\$ 1.00 ; 100$ for $\$ 1.50$. By express, not prepald, 100 for $\$ 1.25 ; 1,000$ for $\$ 10.00$.

AROMA. A good grower and a reliable variety. Berries are of large size, rich in color, with smooth surface and prominent yellow seeds, and a high aromatic flavor. It ripens late and in many sections of the South is the best late variety.

KLONDIKE. This variety is noted for its large yields of beautiful berries, uniform in shape, rich blood-red in color and having a flavor that is neither sweet nor sour, but mildly delicious.

EXCELSIOR. This variety is one of the very best extra earlies yet introduced, and is a vigorous, healthy growerunusually productive for so early a sort-outyielding other standard earlies two to one, while the fruit averages large, is very handsome and firm.

SENATOR DUNLA?. Thoroughly tested and proved one of the best standard varieties wherever tried; strong, hardy, deep-rooted plants; a great bearer of bright, glossy red berries of first-class quality.

GANDY. A reliable late variety, berries bright crimson, very uniform in size and shape, large and firm, plants vigorous and healthy.

BRANDYWINE. A fine, large, late, handsome, productive berry of excellent quality; regular conical form; dark, glossy red, extending to the center. Plant healthy and vigorous, abundant producer.

LADY THOMPSON. Early, strong, upright plants, root deeply; many long runners. Thrives in all soils, but best in rich loam or sand. Berries medium to large, regular, glossy pink, solid, meaty, excellent.

\section{Vestal's Earliest Strawberry}

of all Strawberries in -our list, this ripens the earliest, producing an abundance of perfectly round, beautiful berries of very rich and delicious flavor. In fact it is one of the most productive varieties we have and as it ripens so extremely early it is the favorite home garden variety and also for the large grower, as the market price of the fruit is often 20 cents per quart. A delicious table berry and one of the very best for family use. Price, 25 for 60 cents; 100 for $\$ 2.00$.

\section{Fall Bearing Strawberries}

Fall-bearing Strawberries seem to be no longer an experiment, as they are becoming essential all over the country, and are making good every place they have been tested. If these varieties are disbudded, until say August 15th to September 1st, and allowed to fruit, they will give large quantities of ripe berries until checked by hard freezing. The two varieties we offer we consider the best.

Price, 25 for $\$ 1.00 ; 50$ for $\$ 1.75 ; 100$ for $\$ 3.00$, postpaid.

SUPERB. This is the most wonderful everbearing Strawberry ever produced. It outrivals its parents both in large size and wonderful productiveness. Plants are strong. healthy and deep rooters. The fruit is medium to large in size, very firm, uniform shape, bright red, and has the native Strawberry flavor.

PROGRESSIVE. This is the strongest growing plant of all the fall-bearing varieties we have seen. The plants are very large and heavily rooted, producing a phenomenal crop of medium to large fruits, of a dark red color both inside and out.

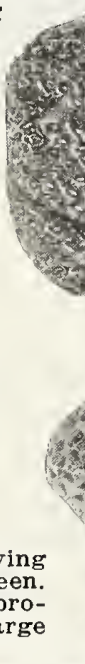

Gentlemen: I am writing just a few lines to say "My Pruit trees and rose plants arrived today in fine condition," and I want to thank you for the nice large trees; also the extra trees and rose plants you kindly sent. MRS. W. H. LANTZ, Muskogee, Okla.

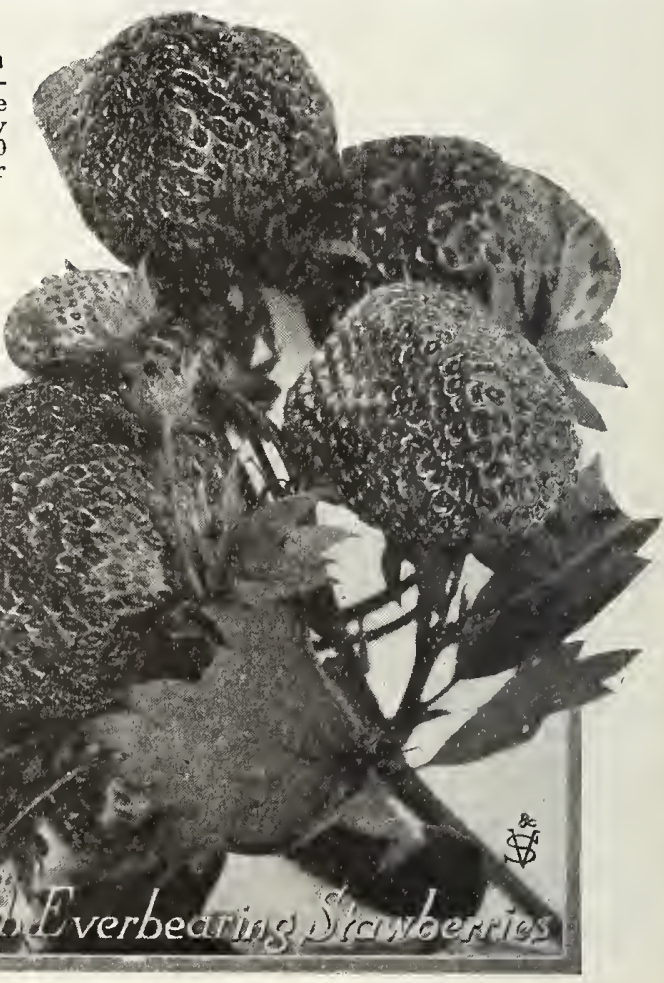




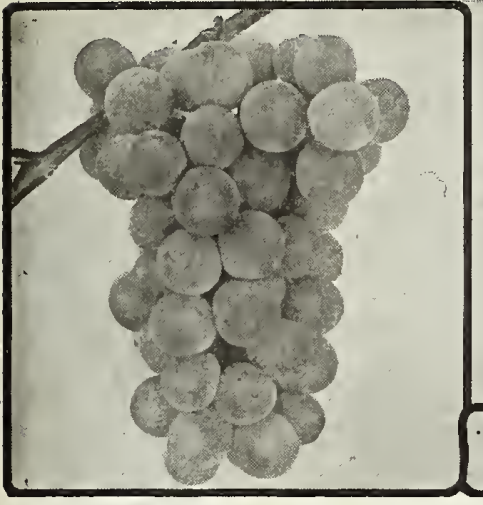

Moore's Early.

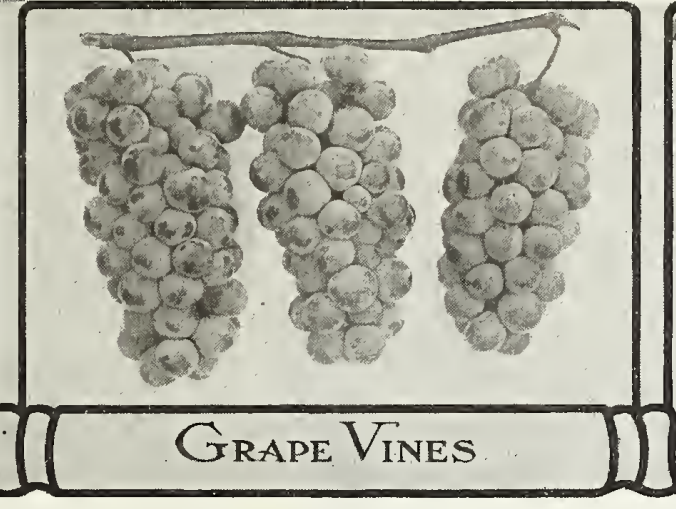

Delaware.

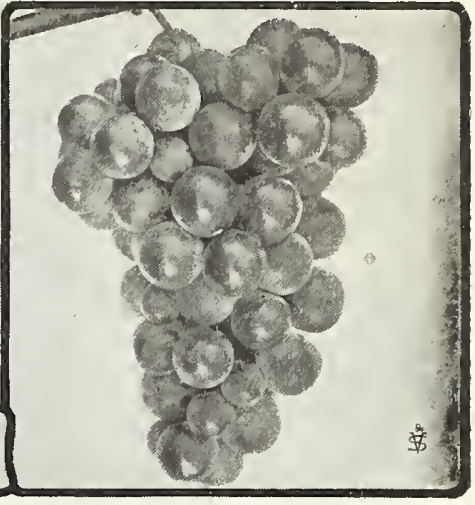

Concord.

Everyone should have a few grape vines in the home garden. They require very little cultivation and returns are quick and abundant. They can be trained over fences, trellises or doorways, and thus be ornamental as well as useful.

Prlce, two-year-old vines, 25 cents each; twelve vines for $\$ 2.50$.

AGAWAM. Berries very large, with thick skin; pulp soft, sweet and sprightly, very vigorous, ripens early.

BRIGHTON. Bunch, large, well formed; berries above medium, round, excellent flavor and quality; one of the earliest in ripening.

CAMPBELL'S EARLY. Bunch and berry large; glossy black.

CONCORD. Considered to be the best all-around grape grown; productive; bunches large, compact, berries large, juicy and. sweet.

WORDEN. A splendid grape of the Concord type, larger, better quality and earlier. Vine vigorous; hardy and productive.

DIAMOND. The leading early white grape, ripening before Moore's Early. White, with rich yellow tinge. 'Fine variety for home garden.

NIAGARA. Occupies the same position among the white varieties as Concord among the black. Bunch and berries large, greenish white changing to pale yellow when fully ripe; quality much like Concord.

MARTHA. Bunch and berries large, when fully ripe a light golden yellow; juicy, tender, sweet. One of the most satisfactory white varieties.

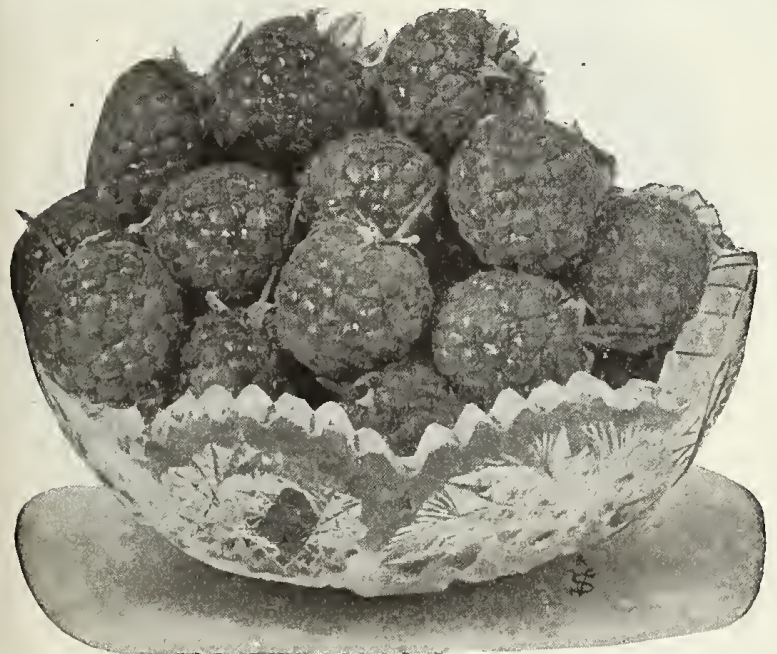

St. Regls-The New Everbearing Raspberry.
MOORE'S EARLY. Bunch large, berry large round, with heavy bloom, vine exceedingly hardy. Its earliness makes it desirable; succeeds admirably in the South.

DELAWARE. Bunch small and compact; light red; very sweet.

EMPIRE STATE. Very large bunch, medium size berries. Juicy, rich, sweet and sprightly.

WYOMING RED. A red grape resembling the Delaware in color and flavor, but much larger.

\section{Scuppernong Grapes}

Price, two-year-old vines, 50 cents each.

\section{Dewberries}

LUCRETIA. (Very Farly Dewberry). Glossy black, large, juicy, sweet. Hardy. Ripens two weeks before Blackberries. Price, $\$ 1.00$ per dozen.

\section{Gooseberries}

One-year-old, each, 25 cents; 12 for $\$ 2.50$.

DOWNING. Whitish green; vigorous and prolific; of splendid quality for deserts or cooking; fine for general culture

HOUGHTON. Medium pale red berries; tender and good; very productive and vigorous.

\section{Currants}

Price, 25 cents each; $\$ 2.50$ per dozen.

CHERRY. Fruit large, bunch small, deep red, acid.

FAY'S PROLIFIC. Extra large stems and berries, color rich red, fine quality, very productive.

WHITE GRAPE. Large, yellowish-white, sweet.

\section{Raspberries}

Price, $\$ 1.00$ per dozen; $\$ 5.00$ per 100 .

COLUMBIAN. Large, dark red, strong, robust and productive.

CUMBERLAND. A black cap of exceptionally large size; of extra fine quality.

CUTHBERT. Large, deep, rich crimson.

GREGG. Large fruit, firm.

KANSAS. The hardiest; strong, good quality.

ST. REGIS (Red). (Everbearing Raspberry). Large, brilliant crimson berries, highest quality. Most productive; only successful everbearing Raspberry. Price, 10 cents each; 12 for $\$ 1.00$.

\section{Blackberries}

Blackberries respond generously to good treatment. They prefer a deep soil, inclined to sand, but will grow and fruit almost anywhere.

EARLY HARVEST, KITTATINNY, RATHBUN, OHMER. Price, $\$ 1.00$ per dozen; $\$ 5.00$ per 100 . 
This page and the next one tells you how you can have a successful vegetable garden without waiting for seeds to grow. If you buy the plants from us, ready started, you gain over a month, and have a supply of fresh, crisp, choice vegetables for your table almost before you know it. What a joy it is to step out from your kitchen door and gather from your own yard the vegetables you want, in all their original freshness and delicious goodness!

A few Artichokes-some choice Tomatoes-a sprig or two of Parsley-possibly a Cabbage or Cauliflower and there's your meal. Such vegetables are not dust covered. Not dried and withered. Not stale and unappetizing. Not handled three or four or five times before they reach you. But clean-and palate-pleasing-right from your own garden to your own table.

You don't need a lot of ground in which to grow a home supply. A few square feet of garden is enough. Order a few plants of the varieties you prefer and you will have fresh vegetables at your command all the year round.

When plants like these are so easily grown-and when the cost of living is so high todaywe can not understand why every house-wife does not grow her own vegetables. The cost of growing is practically nothing-and one can not buy such Vegetables as one can pick from one's own garden patch.

\section{Asparagus Roots}

PALMETTO OR CONOVER'S COLOSSAL. The two most popular varieties of Asparagus. A little corner in your garden planted to Asparagus will give you enough for your needs. For description see Vegetable Seeds. 25 cents per dozen; $\$ 1.50$ per 100.

\section{Horseradish Sets}

WILL GROW IN ANY OLD CORNER, ANYWHERE. Can be grated fresh as wanted and far better than when bought from most vegetable stands, as a little goes a long way. 40 cents per dozen, postpaid; $\$ 2.00$ per 100 .

\section{Rhubarb Roots}

You ought to have a few roots of this delicious vegetable in your garden. It is not only a luscious dish-but very healthful and good for one to eat. Contrary to the opinion of some, it is not at, all hard to grow. Price, 20 cents each; 6 for $\$ 1.00$.

\section{Cabbage Plants}

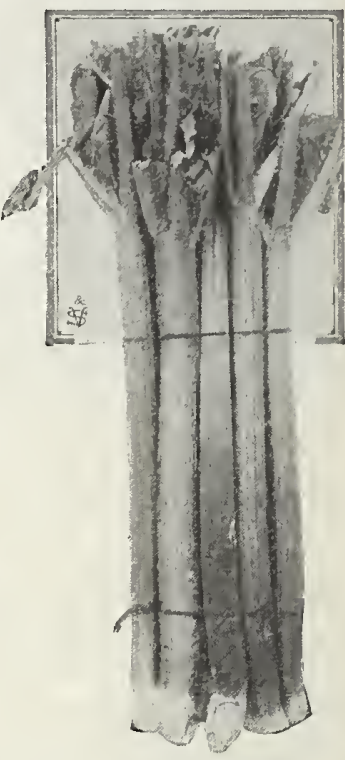

Rhubarb.

EARLY FLAT DUTCH-EARLY WAKEFIELD-LATE PREMIUM FLAT DUTCH-LATE DRUMHEAD-EARLY SUMMER-EARLY ALL.HEAD-SUCCESSION-SURE HEAD. These are the choicest summer and winter varieties. We grow nething but the best-and ship only the strongest and hardiest plants. See full description in Vegetable Seed Section. Field-grown. Ready about March or April. We can supply the above varieties of Cabbage, field-grown, plants at the uniform price of 50 cents per 100; $\$ 4.00$ per 1,000 .

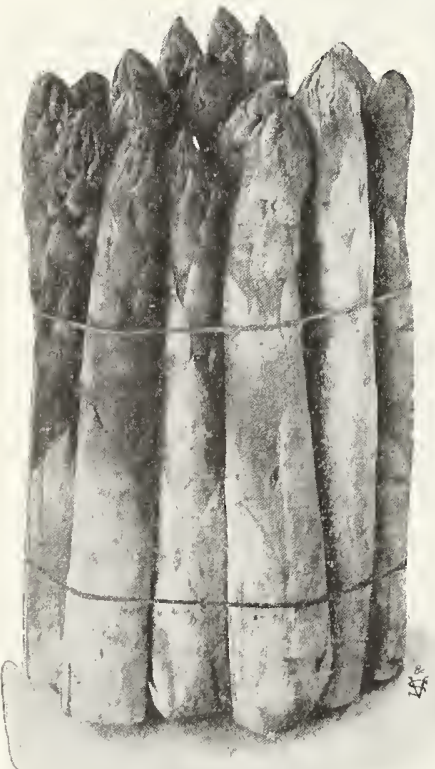

Asparagus.

\section{Cauliflower Plants}

SNOWBALL. Our leading variety. An extremely early-large headed-snow-white Cauliflower that looks good, keeps well, tastes right. You will be delighted with the Snowball Plants. For description see Vegetable Seeds Section. Early transplanted. 25 cents per dozen; 75 cents for $50 ; \$ 1.25$ per 100 .

\section{Egg Plants}

NEW YORK LARGE IMPROVED PURPLE. A choice variety. Easy to grow. Egg Plant is very delicious and very healthful. Pot-grown. Ready about Anril. Large, round, purple variety. 50 cents per dozen; $\$ 4.00$ per 100 .

\section{Celery Plants}

GOLDEN SELF BLANCH.

ING. One of the most satisfactory varieties you can buy. Golden yellow in color with thick, crispy stalks. Tender, sweet, free îrom stringiness. A dozen plants will give you all the celery you will want for greens and table use. It is always fresh and delicious when picked in your own garden, just when you're ready to eat it. Plants, 20 cents per dozen; per hundred, $\$ 1.25$.

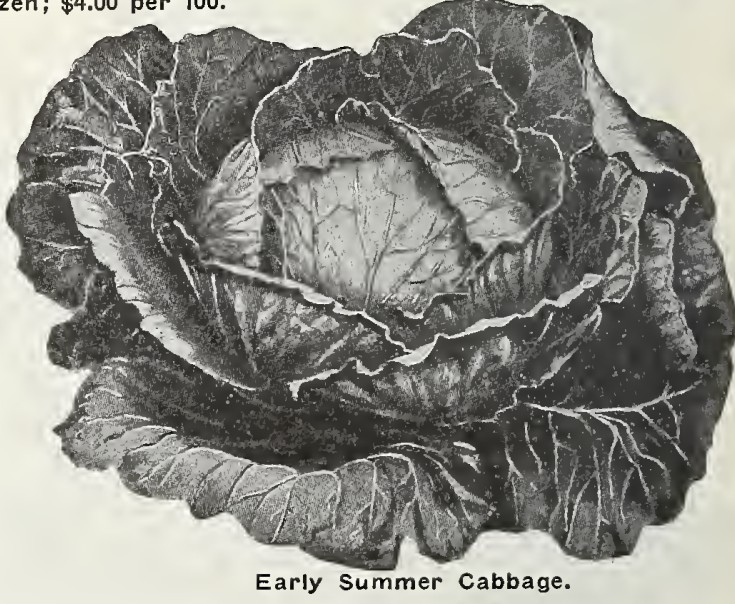




\section{Earliest of All Tomato}

\section{2 for $25 \mathrm{c}-100$ for $\$ 1.50$, Postpaid}

An Extremely Early, Wonderfully Productive Varlety.

This is such an exceptionally fine Tomato that it is deserving of special mention. Extremely Early-and produces heavily all season till cut down by the frost. Large in size with solid meat, smooth skin, and fine deep red color. Richly flavored and a remarkable keeper making it specially desirable as a shipping Tomato. Ready for delivery in March.

\section{Tomato Plants}

At a cost of only a few cents any small family can, with very little care and attention, raise sufficient Tomatoes for their every need. All season long a few plants will supply more than can be eaten, and will produce enough to can for winter use, too. The best varieties for the table or canning: Ponderosa, Stone, Trophy and Earlina. Ready for deliverv in March.

POT.GROWN TO M A TO PLANTS. Ready April. Our Pot-grown Tomato Plants have a splendid reputation. We can supply all the leading varieties. 40 cents per dozen; $\$ 3.00$ per 100 .

TRANSPLA N T E D TOMATO PLANTS. Ready about April. Our plants are all transplanted and the very best in every respect. We can furnish all the leading varieties and in any quantity. 20 cents per dozen; $\$ 1.00$ per 100 ; $\$ 5.00$ per 1,000 .

\section{Lavender}

The leaves are sometimes used for seasoning, but the plant is chiefly grown for its flowers, which are used in the making of perfumes. Price, 20 cents each.

\section{Sage Plants}

Sage is usually wanted when not obtainable. Two or three plants are all that are necessary to give you all the fresh and dried Sage needed. 15c per plant; $\$ 1.00$ per dozen, postpald.
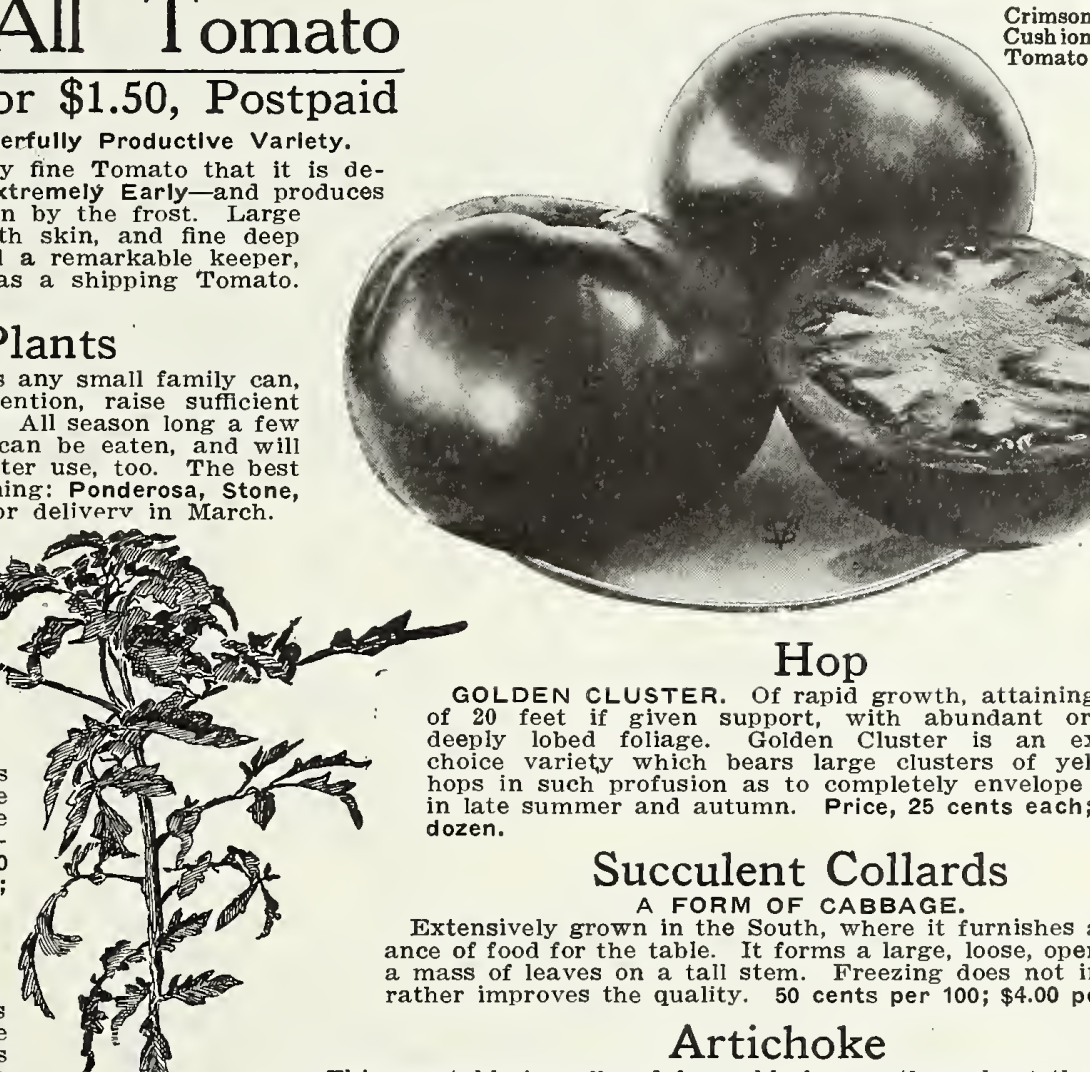

Crimson Cush ion 


\section{The Best New Vegetables, Novelties and Specialties of Merit}

\section{Golden Bantam Sweet Corn}

Is becoming each year more firmly fixed in popular favor because of its extreme early character, vigorous growth, and surpassingly delicious flavor. It is pronounced by thousands of planters the finest extra-early Sweet Corn ever grown. Although the dry grain is entirely free from any flinty glaze, it is exceptionally hard and firm, hence can be planted earlier than any other true Sweet Corn. The stalks are dwarf and sturdy in habit, growing to a height of four feet; they bear two or three good small ears, which have eight rows of broad yellow grains. Pkt., $15 \mathrm{cts}$.; 1/4 lb., 35 cts.; lb., 60 cts.

\section{Sweet Corn}

IMPROVED GOLDEN BANTAM produces a large stalk, as well as an average of two large ears measuring from 8 to 9 inches in length with ten or more rows of large grains. The corn is of strong growth and the large ears are well filled and the grains are exceptionally sweet. The grains are as sweet as the original Golden Bantam, yet remaining soft and tender for a longer period than any early sweet corn. Last year the demand exceeded the supply and we were obliged to refuse many orders. Price, pkt. 15c, $1 / 2$ Ib. $35 \mathrm{c}$, 5 lbs. $\$ 3.75$, postpaid; 100 lbs. $\$ 40.00$.

\section{Detroit Dark Red Beet}

One of the best Beets for the market and home garden. Has a deep, rich color. Tops small, upright in growth; leaves dark green, shaded with red; root medium-sized, nearly round, very smooth, of dark blood-red, zoned with a lighter shade of the same color. Pkt., 10 cts.; oz., 20 cts.; $1 / 4$ Ib., 60 cts.

\section{Full Measure Bean}

A Handsome, Round, Smooth, Green-Podded Stringless Bush Bean. Extra Early, Fine Quality and of Dellclous Flavor.

This extra early variety, although comparatively new, has been pretty widely distributed, and we have yet to hear anything but praise about its fine quality and other merits; it is in fact an ideal Snap Bean, producing a fine crop of round, straight, solid, fieshy pods averaging 61/2 inches long, wonderfully tender and brittle, without a trace of tough interlining, and having no string when broken, excepting when the pods are quite old. The flavor is most delicious, while the delicate green color of the pods is retained after cooking, adding to its attractiveness when served. The plants are of robust, compact habit, unexcelled in bearing qualities, maturing the crop very regularly. It is extra early, the pods being fit to pick four days before other varieties of approximate size. $\mathbf{P k t}_{.}, 15 \mathrm{cts}$.; $1 / 2$ lb., 35 cts.; lb., 60 cents.

\section{Cauliflower}

Pkt., 25 cts; $1 / 4$ oz., $\$ 1.00$; oz., $\$ 3.50$.

EARLY SNOWBALL. Produces large, handsome heads, measuring eight to ten inches across; pure snow white; close, compact and of the finest quality. The stalks are short, of compact growth, and can be planted closely. It is extra early, a very certain header, and equally good for a late crop. Unsurpassed by any strain offered.

EXTRA-EARLY ERFURT. The plants may be depended upon to form large, firm white heads; very early.

When heading, tie the outside leaves loosely over the head to protect it from the sun.
Collards

Pkt., 10 cts.; 1 oz., 30 cts.

GEORGIA SOUTHERN, or CREOLE. Forms a large, loose, open head, or a mass of leaves on a tall stem. Freezing does not injure, but rather improves their quality. Sow thick in drills, in rich ground, transplanting when four inches high, or sow in drills where the plants are to remain and thin to two or three feet apart in the row when of proper size. In the South sow from January to May, and August to October.

\section{Chinese or Celery Cabbage}

This vegetable is called Pe-Tsai, or Cut Cabbage, by the Chinese gardeners, and is beginning to attract attention in America. It does not form a cabbage head, but when grown to its full size resembles the Cos Lettuce, and the outer leaves may be used during its growth. The flavor is mild, and it is used either as a salad or cooked. Pkt., 10 cents.

\section{Pimento Pepper}

Thickest Fleshed of All Peppers-The Solld Meat Is Always Sweet.

The fruits are rich crimson-scarlet in color, while the form is very distinct, being of regular conical shape, as shown in the illustration. The peppers measure from 2 to $21 / 4$ inches across at the stem end and average from 3 to $31 / 2$ inches in length. The skin is perfectly smooth, without any ridges. The peppers are never hot in any part of the fruit, even the fiesh around the seeds being sweet. The fruits are just the right size for stuffing for individual use. The plants branch freely, and produce a heavy crop. We feel sure that the New Pimento Pepper will quickly become very popular. Pkt. 10c, oz. 50c.

\section{Icicle Radish}

\section{Finest Long Whlte.}

Finest and longest of the very early, pure white varieties; ready for use in 20 to 25 days. This Radish is not only crisp and tender when young, but retains these qualities until the roots attain large size, so that it will remain in fine condition longer than any other first-early variety. Is excellently adapted for forcing purposes or successive sowings in the open ground. Pkt. 10c, oz. 25c, 1/4 lb. 75c, lb. $\$ 2.50$.

\section{Iceberg Lettuce}

A beautiful Lettuce, with large, curly leaves of a bright, light green, with a very slight reddish tinge at the edges. Handsome heads, unusually solid because of the natural tendency to the large, strong leaves to turn in, which also causes thorough blanching. Crisp, tender and fine flavor. Pkt. 5c, $1 / 2$ oz. $10 \mathrm{c}$, oz. $15 \mathrm{c}, 1 / 4 \mathrm{lb}$. $50 \mathrm{c}$.

\section{New Davis Perfect Cucumber}

Davis Perfect Cucumber resembles a hot-house Cucumber so closely that dealers can not tell the difference, it being equally good for hot-house or outdoor culture. It is ideal in shape, rich, dark green color, uniform and regular in size. It is exceedingly tender, and as a slicing Cucumber for the table is unsurpassed. It is almost seedless one-third of its length from the stem end, and the seeds contained in it, when in slicing condition, are so small and tender that they are almost unnoticed. Exceedingly productive. Pkt., 5c; oz., 10c; $1 / 4$ lb., 25c; I/2 Ib., $45 c$; lb., $85 c$.

IMPORT ANTTNOTIICE SHIPMENTS OF PERISHABLE GOODS can only be made at your risk. When for作

For twenty-eight years it has been our custom to guarantee the arrival in good order of perishable plants, roots, and cold storage bulbs. This custom for the present period we regretfully are obliged to change. While we will continue to supply and carefully pack such merchandise, we do not wish to hold ourselves responsible for the delays and negllgence of transportation companies.

If shipments arrive in bad condition, accept them and receipt for them accordingly, and make claim for your loss on the transportation company. We, of course, will hold ourselves ready to assist you in any possible way. It has been found that claims can be collected more readily by the person receiving the goods than by the shipper.

Our custom to guarantee the actual arrival of goods, except at points where there is no freight or express agent, will still be continued, and claims for loss or non-arrival of merchandise not perlshable will as In the past be cared for by us, so you run no risk of having to make claims for lost goods. 


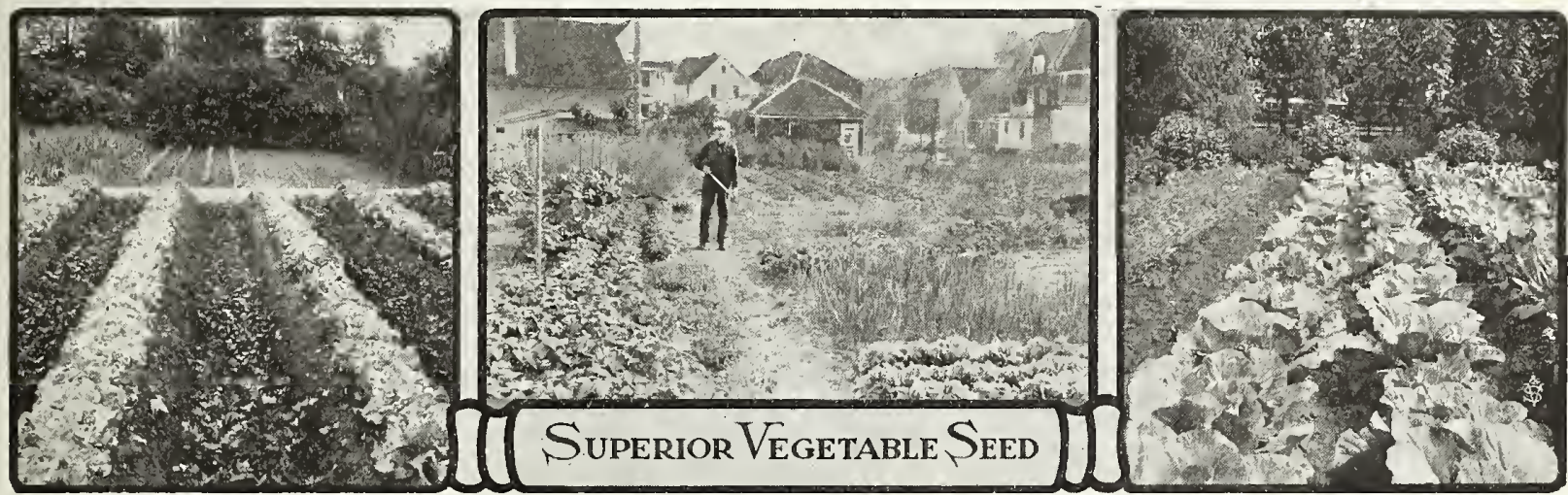

\section{STANDARD VEGETABLE SEEDS}

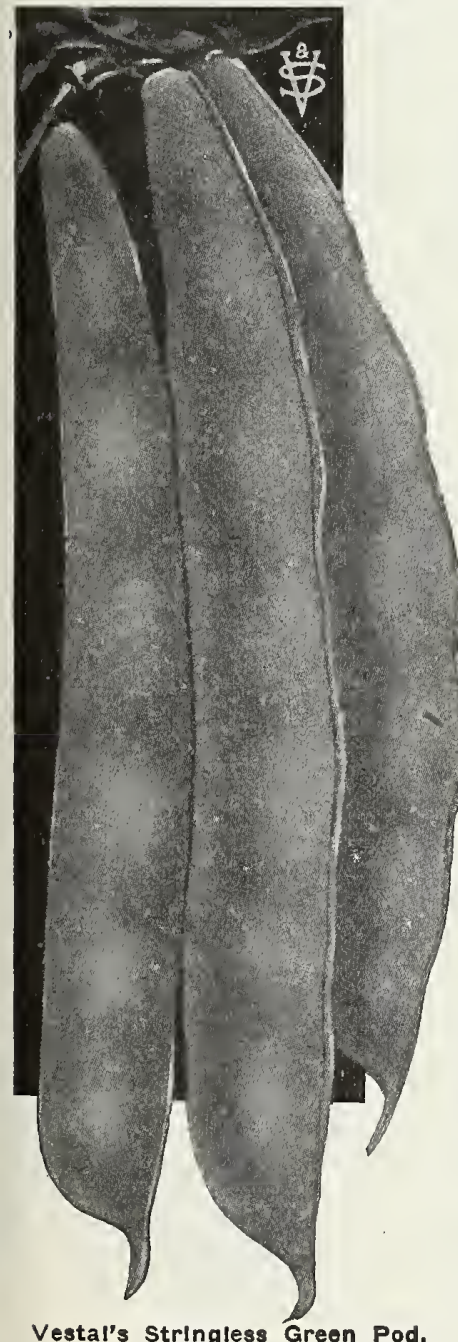

Under this heading we offer standard varieties of vegetables. All our seeds are put up in liberal packets, with full cultural directions upon each. We pay the postage on all seeds ordered by the packet, ounce, quarter-pound, half-pound and pounds, and we guarantee safe delivery in all cases.

As to Our Packets of Seed. The average packet selling at 5 cents postpaid is too small. We, therefore, prefer to put up a more liberal quantity and sell at 10 cents. This is very much more satisfactory, both to you and to us. All seedmen have now adopted the rule of selling all seed by the pound. A quart of Beans or Peas is equal to about two pounds.

\section{Beans, Dwarf Bush or Snap}

Pkt., 15 cts.; $1 / 2$ lb., 35 cts.; lb., 50 cts.

VESTAL'S IMPROVED EXTRA.EARLY RED VALENTINE. Unexcelled for snaps. Preferred by many to the wax varieties. Vigorous-growing vines, bearing many long, roundish pods, deeply creased; flesh, crisp and tender. The Beans are fairly large, pink, marked with red. This variety maintains all the strong points of the various Valentine strains now on the market.

VESTAL'S STRINGLESS GREEN POD. Very early and productive, handsome and of first quality. A fine variety to plant for successive crops; may be grown in this way until killing frost. Pods average 6 inches or over in length; round, thick and meaty, entirely stringless even at maturity.

NEW EMERALD BEAUTY BEAN. The Emerald Beauty is a flat green-podded bush Bean, a prolific and continuous bearer, the first in spring and the last in the fall. It is absolutely stringless, very tender and delicious flavor. The plant is of remarkably handsome and thrifty growth. The rich green pods are of immense size, thick, broad, extra long; uniform shape, solid, meaty and of high quality.

\section{Wax Pod Bush Beans}

Pkt., 15 cts.; $1 / 2$ lb., 35 cts.; lb., 50 cts.

IMPROVED PERFECTION GOLDEN WAX. A medium early variety and a heavy cropper, on vines of vigorous bushy growth, with good rust-resisting nature. The pods are golden-yellow, fleshy and solid, brittle, waxy texture and have an exquisite rich butter flavor, excellent for home and market garden. May be sown any time to early fall with the assurance of a good crop.

NEW DAVIS KIDNEY WAX. The King of Flat Wax Beans. Surely time, energy and brains have culminated in this, one of the grandest Flat Wax Beans. A beautiful form, handsome long pods, attractive color, luscious flavor, prolific yielder, rust proof, excellent shipper, making this grand Bean a perfect success.

\section{Beans, Pole or Running}

Pkt., 15 cts.; $1 / 2$ lb., 35 cts.; lb., 50 cts.

KENTUCKY WONDER, or "OLD HOMESTEAD," The pods, seven to nine inches long, are so fleshy that they are greater in width than in breadth, being deeply creased or "saddle-backed." They are solidly meaty, stringless when young and of finest quality. If pods are gathered as they mature, the vine will continue to bear to the end of the season.

WHITE CREASEBACK. A popular early green-podded pole Bean for snapshorts: of rapid growth and very productive. Pods grow in clusters and are from five to six inches in length, perfectly round, being deeply creased or "saddle-backed" They are solidly fleshy, entirely stringless, and of fine quality. The dry seed is pure white and excellent for winter use.

LAZY WIFE'S. The pods, of medium dark-green color, measure from four and a half to six inches in length. They are broad and retain their rich, tender, and stringless qualities until nearly ripe. Each pod contains 6 to 8 round white beans, which make excellent winter shell beans.

CUT.SHORT, or CORN HILL. An old variety, excellent for planting in hills of corn. Round, slender pods, well-formed, with small white Beans flecked with red. Very prolific and good. 


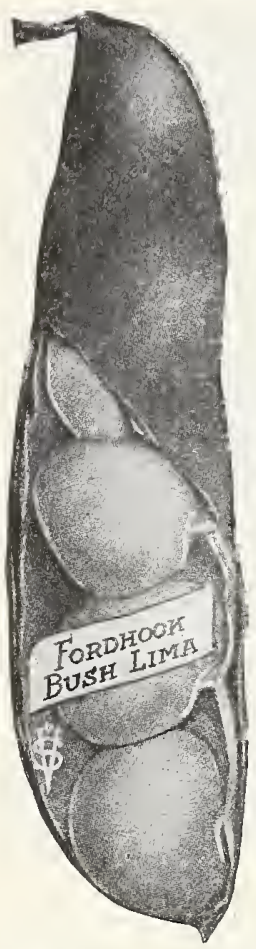

\section{BUSH LIMA BEANS}

Pkt., 15 cts.; 1/2 lb., 35c; lb., 50c.

\section{Burpee's Improved}

Plants True Bush; No Poles, No Stakes

This has uniformly larger pods than Burpee's Bush Lima, while the pods contain more Beans, which are thicker and remain green even in the dry stage. The plants are very prolific, bearing pods in clusters of from 5 to 7. The individual pods average 5 to 6 inches long and contain from 5 to 7 Beans. The Beans are exceedingly thin-skinned and of dellghtful flavor. They almost "melt in your mouth," to use a popular expresslon.

\section{Fordhook}

Enormous Pods and Beans; Equaling

Those of Pole Limas.

The Fordhook is entirely distinct in habit of growth. The stiffly erect bushes branch freely and bear tremendous crops. It is ready for use as early as the popular Burpee's Bush Lima, but the Beans are much plumper and remain green much longer. The shelled Beans are very fat, are closely packed in the pods, which shell very easily. Pods are borne in clusters of from 4 to 6 , average 4 to 5 inches long and contain usually 4 tender Beans of a delightful flavor.

\section{SEREDED POLE LIMA BEANS}

\section{Packet, 15c; $1 / 2$ lb., 35c; 1 lb., 60c.}

Prodigious Yielder; Early and Continuous.

EARLY LEVIATHAN. This will not only give large Lima Beans earlier than any other strrains, but is also much more productive, both early and throughout the season. It is a strong grower, clinging well to the poles, and is a sure cropper. The pods differ from those of other early pole Limas in being straighter and longer. The pods hang out from the foliage in large clusters and contain three or four and sometimes five large beans to the pod.

Delicious Green Limas; From July Until Frost.

Quality and Flavor; Tender, Rich and Buttery-The True Lima Taste.

KING OF THE GARDEN. A strong grower and uniformly large podded. The pods frequently contain five to six very large beans. These beans are of excellent quality, easily shelled; large, handsome appearance.

CHALLENGER OR "POTATO" LIMA. Vines are very productive, but pods mature later than the large flat sorts. The pods are produced in large clusters, and average three to four inches in length; they are quite thick, containing three to five beans, the ends of which are flattened by being crowded closely together. They are of excellent flavor

SMALL-SEEDED POLE LIMA. These are highly esteemed throughout the South as "Butter Beans," and well worth growing North, as they are hardy, early, and extremely productive. They also make good winter shell-beans.

CAROLINA, SIEVA OR SEWEE. (The "Butter Bean" of the South). These grow quickly, mature early, are immensely productive, and continue in bearing throughout the season. The vines are slender, with rather small, shiny, dark-green leaves. Pkt. 15 cts.; $1 / 2$ lb. 30 cts.; lb. 50 cts.

\section{Brussels Sprouts}

Pkt., 10cts.; oz., $30 \mathrm{cts.;} 1 / 4$ lb., 80 cts.

This interesting plant bears a stalk perhaps two feet high, closely covered with little buds or sprouts, one to two inches in diameter which resembles tiny heads of cabbage. These are tender and delicious when creamed the same as cabbage.

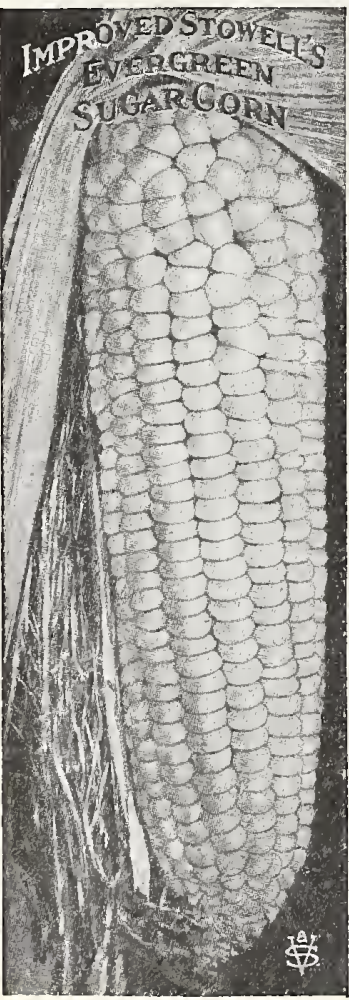

BUTTER BEANS. In the South the Sieva or small Lima, whether of dwarf or tall growth is the "butter bean," while in the North this name is usually given to any wax-podded variety. Please staţe which you want!

\section{CUCUMBERS}

Pkt., 5 cts.; oz., 15 cts.; $1 / 4$ lb., 50 cts.

ARLINGTON' WHITE SPINE. Beautiful in shape, color and of the finest quality. The fruit is long cylindrical, dark green with very white crisp and tender flesh of excellent flavor. In the United States the Arlington is used more, perhaps, than any other variety.

KLONDIKE. A very early strain of White Spine, with dark green skin which holds its color a long time. Fruit 6 to 7 inches long and produced in profusion. Quality unsurpassed.

CUMBERLAND. Is of the hardy, White Spine type, The pickles differ from all other hardy sorts in being thickly set with fine spines over almost the entire surface. During the whole period of growth the form is very straight and symmetrical, thus being as choice for slicing as for pickles.

\section{Corn, Sweet or Sugar Pkt., 15 cts.; lb., 60 cts.}

CALIFORNIA GOLDEN COUNTRY GENTLEMAN CORN. This is a wonderful combination of the "Cream and Honey" Sugar Corn and the well-known "Country Gentleman" Sugar Corn. Could you possibly think of anything more deliciou than the good points of these two corns combined into one? Don't take chances of forgetting it-send in your order today certain.

HOWLING MOB. This is one of the new varieties that has attracted much attention by reason of its many goo points. This is the largest eared Early Sweet Corn in existence, producing two fine large ears to the stalk.

PREMO. Of excellent quality, sweet, and tender. The stalks grow about five feet high, and generally bear two well-developed ears to the stalk.

COUNTRY GENTLEMAN. Excellent for private family use where quality is preferred to size. The cob is very small, giving great depth to kernel.

STOWELL'S EVERGREEN. Hardy and productive, tender and sugary, remaining a long time in a fresh condition suitable for cooking.

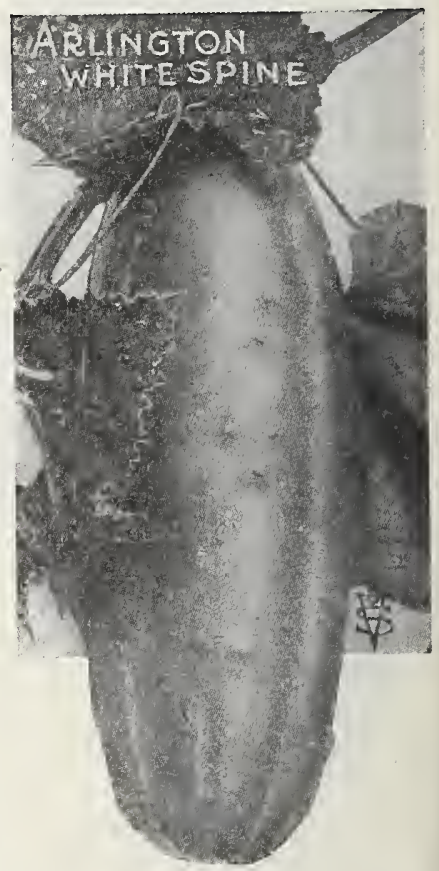




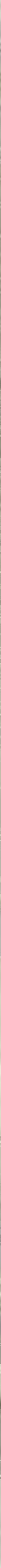




\section{CABBAGE SEED}

Pkt., 10 cts.; oz., 60 cts.; $1 / 4$ lb., $\$ 2.00$; lb., $\$ 7.00$.

EXTRA.EARLY JERSEY WAKEFIELD. Best early variety. Heads of medium size, pyramidal, pointed, firm and solid, with few outside leaves; uniform in size and time of maturing, and of good quality.

LARGE JERSEY OR CHARLESTON WAKEFIELD. HaS uniform heads much larger than Early Wakefield, and matures a few days later. Does as well on clay ground as on other soil. Very popular with Southern gardeners.

ALL HEAD EARLY. For uniformity, reliability of heading, size, earliness and quality it is very superior. Its heads grow compact and free from spreading leaves.

EARLY SUMMER. In size, form, solidity and earliness this is truly a model cabbage. It heads Just after our July Wakefield.

EARLY SUCCESSION. A wonderful Cabbage for solidity, productiveness and fine large heads. Matures early, has handsome color and fine quality.

SURE HEAD. Produces large, round flattened heads that are all head, with fewer outer leaves, very uniform, firm and weighs from 10 to 15 pounds each.

SELECT LARGE LATE FLAT DUTCH. An excellent keeping variety; more extensively grown for main crops than any other sort. Heads large, broad, roundish flat; solid and of good quality.

RED DANISH STONEHEAD. Heads perfectly round and extremely solid; large in size; deep purplish red showing but slight traces of white.

PERFECTION DRUMHEAD SAVOY. Of superior quality; the largest solid-heading Savoy, and has the rich flavor of the cauliflower. The plants are strong and vigorous, and withstand the ravages of the cabbage worm better than other kinds. Pkt., 10 cts.; oz., 30 cents.

\section{Pop Corn}

Pkt., 15 cts.; lb., 50 cts̀.

QUEEN'S GOLDEN. The largest pop corn. The stalk grows to six feet high and bears two to three ears each. It is yellow, but pops perfectly white.

WHITE RICE. Stalks grow six feet high. Produces 3 or more ears on a stalk. The grains are sharply pointed.

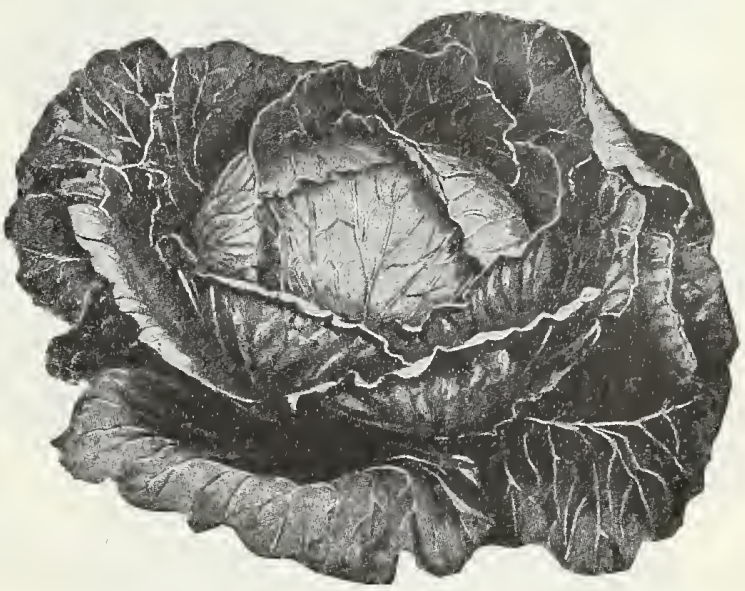

Early Summer Cabbage.

\section{$\mathrm{Ka}^{\prime} \mathrm{e}$ or Borecole}

Pkt., 10c; 0z., 25c; 1/4 lb., 75c; lb., $\$ 2.50$.

DWARF GREEN CURLED, GERMAN GREENS or SPROUTS. Is very dwarf and spreading. The leaves are beautifully curled and of a bright green color. Quite hardy.

\section{Endive or Chicory}

NEW SELF-BLANCHING ENDIVE. A perfect selfblanching curled Endive, beautiful and graceful in shape, most attractive, perfect color, shading from a large, rich golden heart to the outer leaf of emerald green. Pkt., $10 \mathrm{cts.;}$ oz., 15 cts.; 1/4 lb., 60 cts.; lb., $\$ 2.00$.

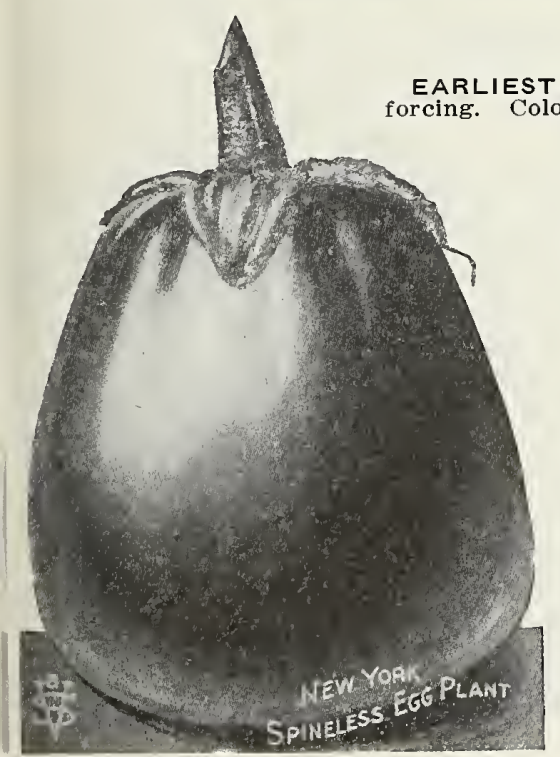

\section{Carrots, Best Table Varieties}

Pkt., $10 \mathrm{cts.}$; oz., $25 \mathrm{cts}$; $1 / 4$ lb., $85 \mathrm{cts}$.

EARLIEST FRENCH FORCING. The earliest small round variety, much used for first early reddish orange, and bunches very
kitchen garden. Quality the best.

EARLY SCARLET SHORT-HORN. Roots deep orange, short and stocky; flesh fine-grained, well-flavored; grows well in shallow soil. One of the best for outdoor planting and table use.

OXHEART. An early, short, thick variety of fine quality. Popular for market use when small, as it can be bunched to good advantage. Deep orangecolored roots, thick and fleshy, with little core.

LONG ORANGE. Latest and largest of all. Deep reddish color, thick and fleshy with a small core. Valuable also for stock feeding.

\section{Celery}

Pkt., $10 \mathrm{cts.;} \mathrm{oz.,} 25 \mathrm{cts.;} 1 / 4$ lb., $85 \mathrm{cts}$.

GOLDEN SELF-BLANCHING. Of dwarf, compact growth with thick, solid stalks which blanch readily to a beautiful creamy white. Requires very little earthing up to blanch crisp and hard. Very easy to grow,

WHITE PLUME. A good, early variety somewhat similar to Golden Selfblanching. Pure white, tender, and delicately flavored.

\section{Eggplant}

Pkt., $10 \mathrm{cts.}$; oz., $60 \mathrm{cts}$; $1 / 4$ lb., $\$ 2.00$.

BLACK BEAUTY. From ten days to two weeks earlier than the purple varieties, and of rich, luscious, purplish black color, distinct sort and a favorite where known. The plants are remarkably healthy in their growth and yield an abundance of large fruits. The fruit is very attractive in appearance. This variety is entirely spineless. Very best.

NEW YORK IMPROVED LARGE PURPLE. A leading variety; fruit very large, oval-shaped, smooth, deep purple; flesh white and of good quality. The seed we offer is a very fine strain of this popular sort. 


\section{Lettuce}

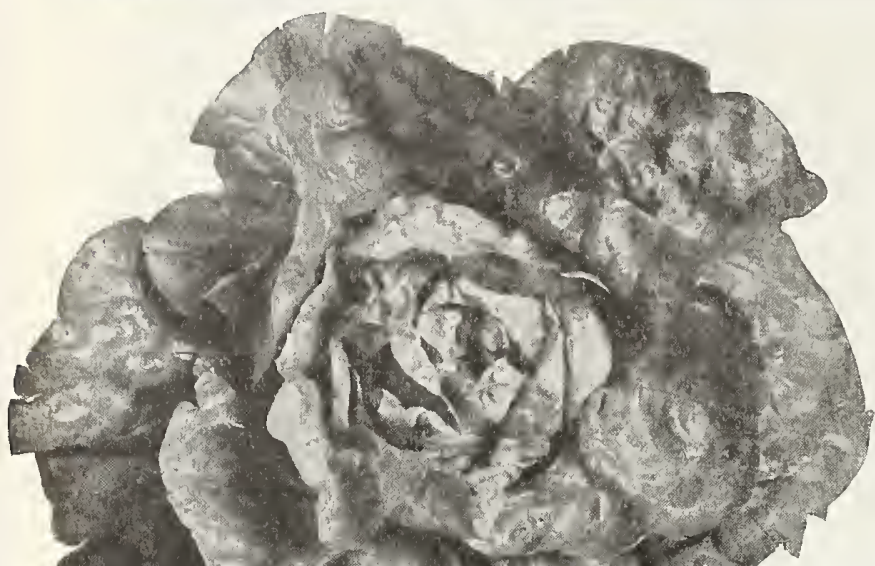

Pkt., 5 cts.; oz., 20 cts.; 1/4 lb., 50 cts.; lb., $\$ 1.75$.

BIG BOSTON. With Southern gardeners who ship North, this is most popular, the best early large heading sort South; a valuable first early. Plants are vigorous, mature large heads of bright green leaves, which are very tender.

CALIFORNIA CREAM BUTTER LETTUCE. Outside leaves are a medium green color, inside is folded a solid head of rich, creamy yellow color. The largest growers consider it one of the best in cultivation.

"ALL SEASONS." A handsome, very large, solid head, leaves a beautiful light green and the inner ones are very tender, crisp and a beautiful golden color. It goes to seed very slowly.

HANSON. Grows to large size and is uniformly sure heading. Heads very solid and beautifully blanched, crisp, mild and tender. One of the finest varieties to grow for market during the summer months.

WAYAHEAD. Very early sure-heading and finest quality. Heads very large and solid. Outer leaves light green, inner yellow.

MAY KING. A handsome, light green heading variety of medium size and excellent quality. Outdoors the heads mature exceptionally early, attaining a size suitable for use before other

Callfornla Cream Butter Lettuce.
18 $8+x^{2}+15$ sorts, and often the edges of the outer leaves have a brownlsh
is very compact for so large a head. It is very satisfactory also tinge. The plant is very

\section{Watermelons}

Pkt., 10 cts.; oz., 15 cts.; 1/4 lb., 40 cts.; lb., $\$ 1.25$.

KLECKLEY'S SWEETS. A variety of great merit. The skln is a little too thin to make it a good shipplng variety, but for home use or local markets it is one of the leaders. The melons are large, oblong, with dark green skin and bright scarlet flesh; solid to the heart and of luscious flavor, ripening early.

FLORIDA FAVORITE WATERMELON. The flesh is a beautiful, clear crimson, extending to the rind. The rind is tough, making it an excellent shipper. It is beautifully striped light and dark green, and a very large yielder. The shape is oblong, the flavor is sweet and melting, making it one of the best in cultivation, both for the home garden and large growers.

GEORGIA RATTLESNAKE. Has gained great popularity for its large size and great shipping qualities; shape oblong, of light green color and beautifully mottled and striped with a light shade; flesh scarlet; rind thin, very solid, and both sweet and delicious.

DUKE JONES. One of the largest and most productive melons. Early, round and of fine appearance; of fine flavor and a great shipper.

JUMBO. One of the finest of melons; shape round to oblong, rind green with lighter colored stripes, flesh deep red, surpassing most other varieties in flavor; one of the best for shipping. Average weight 40 to 60 pounds; have been known to weigh 80 pounds.

HALBERT HONEY. A very sweet, long, dark green variety. Fruits average 18 to 20 inches long, have a thin rind and deep red meat of delightfully delicious flavor; pulp entirely free from stringiness; seeds white. One of the finest for the home garden.

SWEETHEART. Large, heavy melons, with pale green skin netted with darker lines; solid, deep rich red flesh, crisp and delicious; a first-class shipper.

WATSON. A large oblong Melon, the skin of which is dark green, with thick netting all over, quite distinct from other varieties. The rind is thin, but tough, and the flesh a bright, attractive red color, of a delicious, sweet and satisfying flavor. It is a very good shipping Melon.

\section{Mustard}

Pkt., 5 cts.; oz., $15 \mathrm{cts}$.; $1 / 4$ lb., 40 cts.; lb., $\$ 1.25$

SOUTHERN GIANT CURLED. This is very highly esteemed in the South, where the seed is sown in the fall, and the plants used very early in the spring as a salad.

FORDHOOK FANCY. This is the finest of all mustard, curled like an ostrich plume. In fact, it is sold under the name of "Ostrich Plume." Splendid flavor, can be cooked any time of the year, like spinach, and by many is considered far superior.

\section{Muskmelons}

\section{Pkt., 10 cts.; oz., 20 cts.; $1 / 4$ lb., 60 cts.; lb., $\$ 2.00$.}

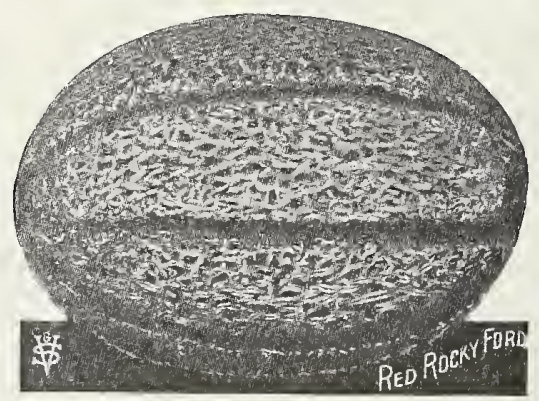

MONTREAL NUTMEG. The larg e fruits are nearly round in form, slightly flattened at the ends, with very large broad heavy ribs. Dark green skin, th i ckly covered with heavy netting. The flesh is two Inches thick, light green, melting, delicious flavor.

BURRELL GEM. The melons are six to seven inches long by four and a half to five inches in diameter, rather sharply sloping at the ends. They are quite well ribbed and covered with a fine grayish netting. The skln is a rlch dark green, contrasting finely with the deep orange-salmon colored flesh, sweet and tender. The flesh is thick and firm, ripening close to the skin, leaving only a thin rind.

ROCKY FORD, or NETTED GEM. Oval-shaped; small and uniform; thick-meated; flesh light green in color and of uniformly fine, luscious flavor; skin ribbed and thickly netted; prolific.

"PAUL ROSE." The fruits are nearly round or slightly oval, ribbed and heavily netted; of a light green or faint golden hue when fully ripe. The flesh is thick of a rich deep orange color, and ripens close down to the rind, with small seed cavity.

DELICIOUS GOLD LINED MUSKMELON. Growers of muskmelons, both for home use and for market, will be delighted with "Delicious Gold Lined." The melons are same size as "Rocky Ford," but specimens run more uniform as to size and shape, which is nearly round, and the skin is covered with a thick grayish netting, adding much to the appearance of the melon. The flesh is green, with slight golden tint next to the seed cavity, and the flavor is delicious, being remarkably sweet and juicy. 10c per pkt.; oz., 20c; $1 / 4$ Ib., 50c.

\section{Okra}

Pkt., 10 cts.; oz., 15 cts.; 1/4 lb., 40 cts.; lb., $\$ 1.25$.

WHITE CREOLE. Pods long, round, smooth; velvety white surface.

LONG POD. Productive; pods very long and slender; deep reen. 


\section{Peas Extra Early and Early}

Packet, 15 cents; lb., 50 cents.

ALASKA. An extra early hardy Pea. Pods of perfect shape, well filled with smooth peas of unrivaled quality. Seed blue.

GRADUS. An early wrinkled Pea, which is very hardy and can be planted extremely early. The vine grows about $21 / 2$ feet high. Pods large and well filled with good sized peas. One of the earliest.

NOTT'S EXCELSIOR. This excellent dwarf wrinkled extra early Pea is robust and vigorous and produces in profusion handsome pods, closely packed with large peas of fine flavor.

THOMAS LAXTON. An early variety of large-podded Pea. The plant is a very hardy and strong grower, producing extra large size pods in abundance, and the quality is delicious. This variety will mature as early as many of the smooth extra early Peas; height, 3 feet.

\section{Second or Medium Early Sorts}

MCLEAN'S ADVANCER. A green, wrinkled variety, about $21 / 2$ feet high, with pods abundantly produced, and filled to the end; of excellent flavor. A first-class Pea in every respect.

EVERBEARING. Grows about 20 inches high; pods of good length; peas very large, wrinkled and in quality unsurpassed. For continuance and profusion of bearing this variety is unexcelled.

\section{Late or Main Crop}

IMPROVED STRATAGEM. One of the finest dwarf wrinkled Peas. Their quality is unsurpassed, vines grow to a height of eighteen or twenty inches, do not require sticking and are loaded with pods that are crowded with immense dark green peas.

CHAMPION OF ENGLAND. One of the richest and best flavored peas grown; height three to four feet, seed wrinkled, whitish green and much shriveled.

TELEPHONE. One of the flnest tall wrinkled marrows yet introduced. Vine strong, producing abundantly. The pods are of large size and filled with large delicious peas. Height three to four feet.

PROLIFIC GIANT PODDED SUGAR PEAS. Excels all other Sugar Peas in size, productiveness and quality. Vines are about 30 inches in height. The pods are gigantic in size, broad, sweet and tender, extremely fleshy and equal to the best Snap Beans for cooking pods and all. This is a very decided improvement in Sugar Peas.

\section{Rutabagas or Swedes}

Pkt., 10 cts.; oz., 20 cts.; 1/4 lb., 60 cts.; lb., $\$ 2.25$.

Sow from the 20 th of June to the middle of July, in drills two feet apart and thin out to eight inches in the rows.

IMPROVED GOLDEN HEART RUTA$B A G A$. One of the best of the Swedes; hardy and productive; flesh yellow, sweet and well flavored; shape slightly oblong, terminating abruptly; color purple above and yellow under the ground; rich in flavor.

LARGE WHITE RUTABAGA (Sweet

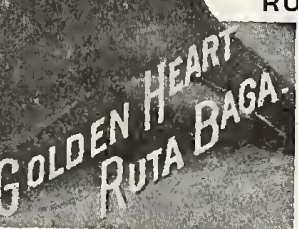
Russian). This variety is most excellent either for table or stock. It grows to a large size: flesh wh i t e, solid, firm tex$t u r e$, sweet a n d rich: keeps well.

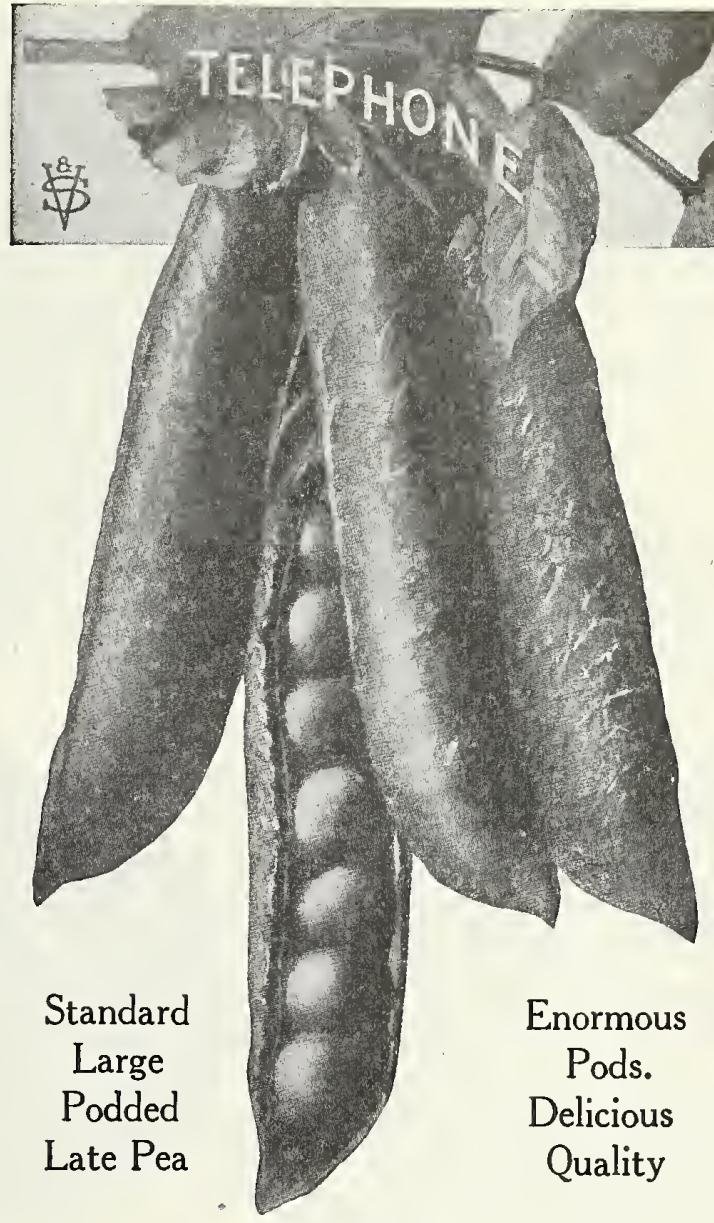

\section{Turnip}

Pkt., 10 cts.; oz., 20 cts.; 1/4 lb., 50 cts.; lb., \$2.25.

YELLOW GLOBE. One of the best for general crop; flesh firm and sweet; grows to a large size, excellent for table use or feeding stock.

PURPLE TOP WHITE GLOBE. Originated from the "Purple Top Flat Turnip," and is extensively planted, and popular for its qualities. The flesh is firm, fine grained, sweet and rich flavored; it is of good size and globe shaped, has a splendid appearance, is a good producer and fine keeper. A splendid table variety and tip-top for stock.

EARLY PURPLE TOP. Strap leaved. Fine table variety, being tender and of delicious flavor. It is in season about a week later than White Milan, in shape it is broad and flat like a disc, medium size, fesh white, fine grained and tender. On top the color is dark red or purple, below white, has few leaves, entirely upright in growth, good keeper.

EARLY WHITE FLAT DUTCH. An early white leaved variety; of quick growth, mild flavor and excellent quality; also grown for a fall crop.

COW HORN or LONG WHITE. This variety is pure white, carrot-like in form, growing nearly half out of the ground and slightly crooked. It, is delicate and well flavored. Used also as a green manuring crop.

SEVEN TOP. Cultivated extensively in the South for the tops, which are used for greens. It is very hardy and will grow all winter, but does not produce a good root. 


\section{Everbearing Tomato MY MARYLAND}

The Earllest, Largest, Most Prolific and Meatiest Red Tomato Grown.

Wonderfully prolific new Tomato. Clusters average 15 fine, large red or scarlet Tomatoes, and the beauty of it is that they all run about the same size, absolutely free from the acidy taste so common in most varieties. Seed-cavities are exceedingly small, we believe it to be the meatiest Tomato grown. This Tomato combines all the good qualities of each parent-earliness of the Earliana, size from Ponderosa. When cut by the frost there is still plenty of green fruit on them. Originator's own stock. Pkt. 20c 2 pkts. $35 \mathrm{c} ; 1 / 4$ oz. $\$ 1.00$.

\section{Ponderosa - The Giant Tomato}

The largest variety of practical value. The plants ripen early and bear well until very late; very solid, almost seedless, of good sub-acid flavor and of immense size, frequently weighing considerably more than 2 pounds. Somewhat scattered on the vine, and a small percentage are rather rough. Our strain, however, is now producing a much smoother fruit than when first introduced. Good Tomato for home use; splendid slicer. Pkt. 10c; 1/2 oz. 40c; oz. $75 \mathrm{c}$.

\section{Acme}

Pink purple. Vine hardy and productive. Fruit in clusters of 4 or 5, round, smooth and of good size; flesh solid, excellent flavor, no better variety for market gardeners who want an early purple fruited sort. Pkt. 10c; oz. $35 \mathrm{c}$.

\section{Livingston's Dwarf Stone}

The advent of Dwarf Stone marked a new epoch in Dwar Tomatoes. The fruits are larger than those of Dwarf Champion and nearly as large as those of our Standard Stone.

It is very prolific. Fruit smooth; ripens evenly. The color is bright red. You may set the plants of Livingston's Dwarf Stone as close as 18x24 inches and still produce an abundant crop. Pkt., 10c; $1 / 2$ oz., 35c; oz., $55 \mathrm{c}$.

\section{New Globe}

This new Globe or Ball shaped Tomato is ideal for the home garden; it is excellent for slicing without waste, one slice like another. The rich, juicy, meaty tomato flavor gives a certain zest and joy in the eating. The vines ripen the first fruits with the second earlies, they yield a heavy crop and continue to bear until frost. Price, per packet $10 \mathrm{c}$; $1 / 2$ oz. $35 \mathrm{c} ; 1$ oz. $60 \mathrm{c}$.

\section{Crimson Cushion}

Or Beefsteak Tomato, is very large, round and regular bright scarlet skin, flesh solid, best quality, seed cells smal and few. Plants are very prolific, fine appearance. Price, per packet $10 c ; 1 / 2$ oz. $35 c ; 1$ oz. $60 c$.

\section{Earliana}

The earliest smooth, bright-red Tomato of good size. It has been developed in the light, warm soil of Southern New Jersey, where effort is made to market Tomatoes at the earliest, possible date. It is so far superior in hardiness, sure-setting of fruits, size and smooth uniform shape, now practically controls the markets of our Eastern cities during the last week of June and the month of July. The plants are compact in growth, with short, close-jointed branches, setting fruits very freely. With our strain the Tomatoes are quite uniform in size and of smooth regular form, averaging three inches in diameter and from two to two and a half inches in depth; they are fleshy, solid and excellent for shipping purposes. Price, per packet $10 \mathrm{c} ; 1 / 2 \mathrm{oz}$. $35 \mathrm{c}$; 1 oz. $60 \mathrm{c}$.

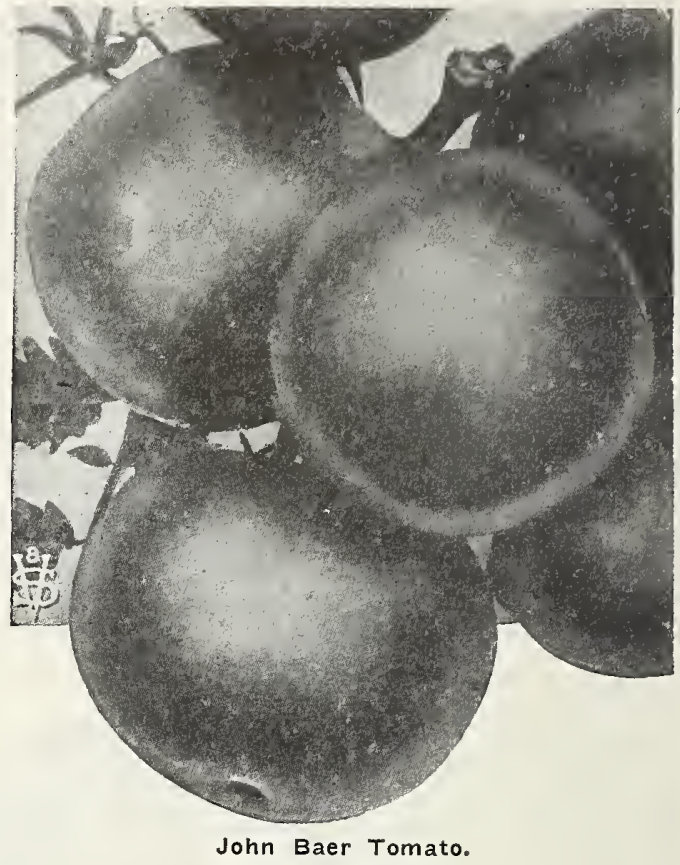

John Baer

Fruits are the largest of the extra early sorts and are also most attractive in color. They are nearly round, smooth, firm and of excellent quality. It is one of the very earliest to ripen its first fruits and it continues to furnish marketable fruits much longer than other very early varieties. An invaluable sort for market gardeners' use. Our seed is grown from originator's stock. Pkt. 10c; oz. 40c; $1 / 4$ lb. $\$ 1.25$.

\section{Squash}

Pkt., 10 cts.; oz., 15 cts.; $1 / 4$ lb., 50 cts.; lb., $\$ 1.75$.

WHITE BUSH SCALLOP, PATTYPAN. Commences maturing early and will bear throughout the season if Squashes are kept gathered. Large; pure white skin; flesh is of fine quality.

YELLOW BUSH SCALLOP. Very early flat variety with edges regularly marked or scalloped. Skin pale yellow, flesh deep yellow, of fine flavor with small cavity.

GIANT SUMMER CROOKNECK. A long, roundish Squash with the stem completely turned back upon itself. The seed we offer produces Squashes much larger than the ordinary Crookneck type of the old gardens.

\section{Fall and Winter.}

Pkt., 5 cents; ounce, 15 cents; $1 / 4$ lb., 50 cents.

GOLDEN HUBBARD. Skin and flesh deep yellow. Very dry and of excellent flavor. Particularly good for pies on account of its bright color.

HUBBARD. A standard late Squash. Skin dark green: flesh fine grained, dry, sweet, late keeping.

IMPROVED CUSHAW. Skin mottled green with stripes. Very solid, with yellow flesh which is fine grained, sweet and excellent for pies.

WINTER CROOKNECK. A favorite late keeper, remaining in good condition for months after all others are gone; yellow skin; sweet, fine-grained flesh.

\begin{tabular}{|l|l|l|}
\hline If you have been particularly successful with any of our seeds, \\
tell us about it. It will help us to induce others to be successful.
\end{tabular}




\section{Parsnips}

Packet, 10 cents; ounce, 30 cents; $1 / 4 \mathrm{lb}$. $\$ 1.00$ : $\mathrm{lb} ., \$ 3.00$.

IMPROVED HOLLOW CROWN. The variety most cultivated. The roots are tender and sweet, and their yield per acre is heavy. Always good and in demand.

IMPROVED GUERNSEY. An improvement over "Hollow Crown." much larger in diameter, but not so long the roots are more easily gathered. This sort gives general satisfaction, having good quality.

\section{Parsley}

Packet, 10 cents; ounce, 20 cents; $1 / 4 \mathrm{lb}$., 50 cents; Ib., $\$ 1.50$.

Parsley is used for seasoning soups and stews, for salads, and is also very universally used for gardening; also for ornamental borders in the flower garden: succeeds best in rich, mellow soil. As the seeds germinate very slowly, three or four weeks sometimes elapse before it makes its appearance. It should be sown early in the spring.

CHAMPION MOSS CURLED. A compact growing, fine-cut and beautifully curled variety.

\section{Crisp Radishes}

Pkt., 10 cts.; oz., 30 cts.; V/4 lb., $\$ 1.00$.

WHITE-TIPPED SCARLET TURNIP Bright scarlet with clearly defined white tips. Foliage short, making it well adapted for forcing. A great favorite. Packet, 5 cents.

EARLY ROUND DARK RED. Very early, small round Radish: entire Radish is of a rich, scarlet color. This splendid variety has always been a great favorite with market gardeners and for kitchen garden alike.

BRIGHTEST LONG SCARLET (Cardinal White-Tipped). Resembles Early Long Scarlet Short-Tipped in shape and size; extra-early; bright scarlet; white-tipped; a rapid seller.

SCARLET GLOBE. This splendid globe Radish is the very finest early strain of the round, bright red Radishes. Nothing can surpass its table excellence or its beauty. The skin is a bright scarlet; flesh pure white, crisp, tender and of delicious quality. Fine for market gardeners who want a large first-early forcing Radish.

FRESH BREAKFAST WHITE TIPPED ROCKET. Of quick growth: very mild and tender; of an oval form scarlet tipped with white. One of the best for home garden.

LONG WHITE ICICLE. Grows about 4 inches long; slightly stumprooted, and of transparent whiteness; short leaves, matures quickly; most excellent flavor; equally desirable for home.

EARLY SNOWBALL. One of the quickest growing, besides one of the prettiest round varieties in the whole list; white as snow, smooth as glass, very crisp and extremely tender.

\section{Winter Radishes}

Pkt., $10 \mathrm{cts}$; oz., 30 cts.; 1/4 lb., $\$ 1.00$ ROSE CHINA WINTER.

CALIFORNIA MAMMOTH WHITE.

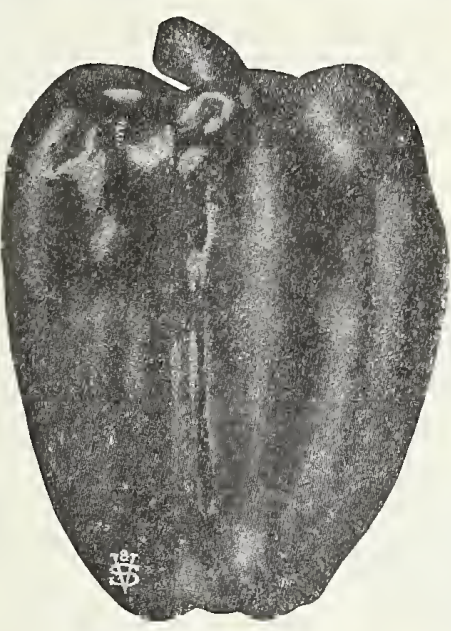

Mammoth Ruby King.

\section{Peppers}

Packet, 15 cts; ounce, 75 cents.

CHINESE GIANT. Without doubt one of the very best and largest Mango Peppers that was ever introduced. Its mammoth size, splendid shape, beautiful, Fich glossy flesh and mild flavor, all lead us to speak of it in words of commendation. Very popular with all. Its strong. bushy plants, which are literally loaded with the splendid large fruits, begin bearing quite early and continue throughout the season.

SWEET MOUNTAIN. One of the large sorts. Very thin skinned, sweet and mild flavored; much used for stuffed pickles.

LARGE BELL, or BULL NOSE. An early variety and of mild flavor; the skin is quite thick and fleshy; of medium size; is very popular.

MAMMOTH RUBY KING PEPPER. Extra selected stock. This magnificent variety is now recognized as one of the best Red Peppers for market or family use.

RED CAYENNE. Long slim pod, rather pointed; bright red when ripe; very hot and pungent.

\section{Pumpkins}

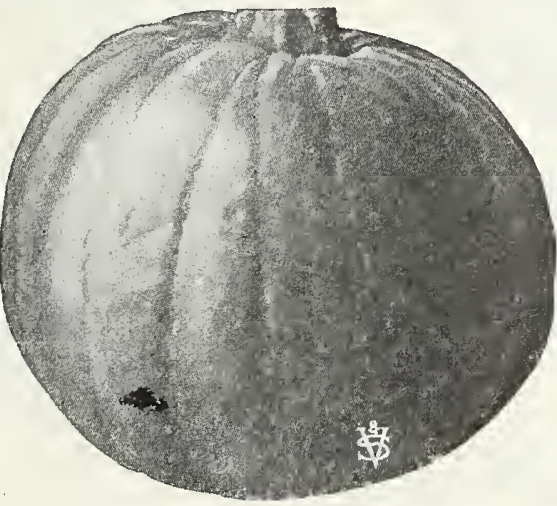

Mammoth Prize Pumpkin

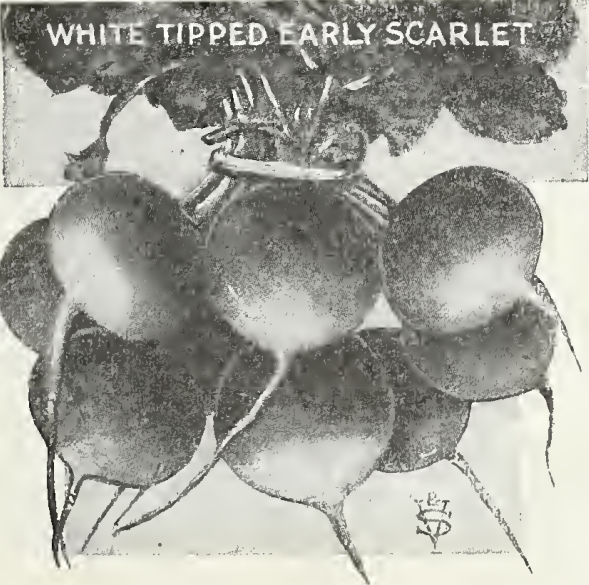

Pkt., 10 cts.; oz., 20 cts.; 1/4 lb. 50 cts.; Ib., \$1.75.

LARGE CHEESE. Of large size shape flat like a cheese box, very pro ductive. Keeping quality excellent proextra well flavored and sweet. A good sort for pies as well as stock feeding Skin buff color; flesh yellow.

WINTER QUEEN OR WINTER LUXURY. Generally regarded as the finest quality pie Pumpkin its high quality it is the best winter keeper of all. In size about nine ten inches in diameter; its skin is beautiful deep orange yellow with very close netting almost as russeted as a potato.

LARGE FIELD, OR "BIG TOM." The standard Pumpkin grown in corn fields to make a feeding crop for cattle. The vines are stron for cat and wonderfully prolific. Fruits average 15 to 20 inches in diameter. Smooth, hard reddish orange skin with rich orange yellow flesh.

SUGAR PIE PUMPKIN. Is so well known as the best pie Pumpkin it quires little description. The fruit is small to medium size, with solid fine grained flesh, sweet sugary, delicions flavor. They all call for "more;" the seed cavity is small.

KING OF MAMMOTH. A really enormous variety; specimens have been grown as large as 200 pounds. Notwithstanding its immense size it is among the best pie Pumpkins. Flesh fine-grained, sweet and tender. Requires a late crop corn season to mature and should be given plenty of room (one plant to a hill) to reach its largest size.

\section{Spinach}

VICTORIA. A new variety; dark green leaves: long standing. We can recommend this very hightly. PKt. $10 \mathrm{c}$

BLOOMSDALE ROUND - SEEDED SAVOY. The best for family purposes. Packet, 10 cents. 


\section{Vestal's Reliable Flower Seeds}

In the following pages is offered a carefully chosen list of Flower Seeds, in which no want of the flower-garden has been neglect, the numerous varieties insuring a wide range of color, form, height, habit and season, thus permitting selection for any and every ornamental purpose.

PLEASE USE THE ORDER SHEET that is enclosed in catalogue; by so doing, the filling of orders is speeded, and the chance of errors lessened. The complete index will contribute to an easy and rapid selection of seeds wanted.

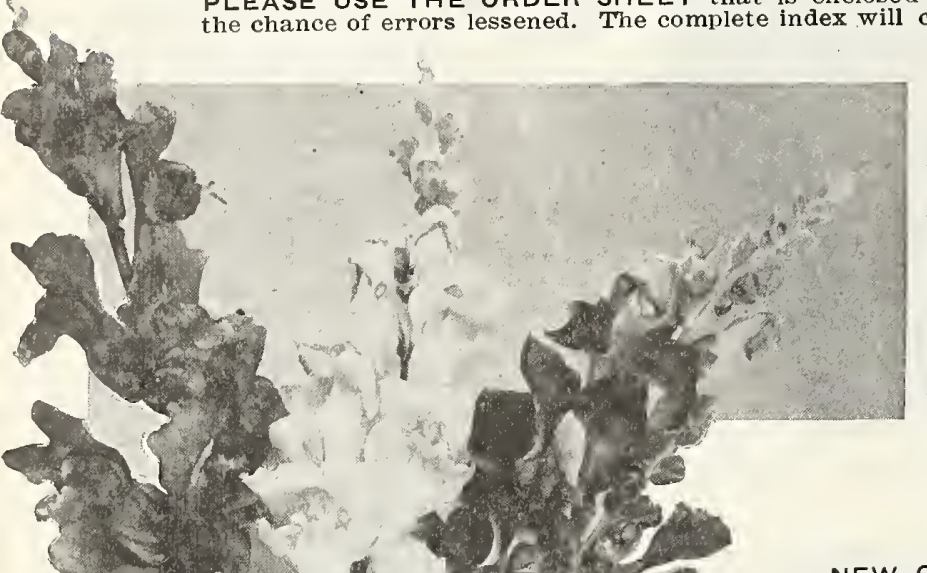

Asters

GIANT' CHRYSANTHEMUM FLOWERED. We offer four of the most distinct colors separate, also choicest mixed. Pure White, Light Blue, Dark Blue, Rose. Price, per packet, 10 cents; three packets for 25 cents; six packets for 45 cents. Mixed colors, including all of the above and many other colors. Price, per packet, 10 cents.

SEMPLE'S BRANCHING. They bloom two to three weeks Te offer them in four separate colors. Pure White, Crimson, Lavender, Bright Pink; also choicest mixed. Price, per packet, 10 cents each; three packets for 25 cents; six packets for 45 cents.

TRUFFAUT'S PAEONY FLOWERED PERFECTION Flowers very large, double and beautifully incurved; grow about eighteen inches high. Over twenty-five distinct colors are included in the splendid strain we offer. Mixed seed. Price, per packet, 5 cents.

NEW QUEEN OF SPRING. The plants are vigorous and healthy of low, dwarf growth, and produce their queenly heate double flowers profusely. Price, per packet, 10 cents. NEW GIANT COMET MIXED. Flowers of large size, closely resembling curled Chrysanthemums. All colors mixed. packet, 10 cents.

MIXED ASTERS FOR GENERAL PLANTING, our own mixture, embracing many choice varieties. Price, $1 / 4$ oz., 75 cents.

\section{Allegheny Vine}

ADIUMIA CIRRHOSA. A graceful hardy climber; the feathery resembles that of the Maiden Hair Fern, the flowers foliage closely resembles that of the Maiden cover the plant. Price, per packet, 10 cents.

\section{Aquilegia (Columbine.)}

DOUBLE VARIETIES, Finest Mixed. Price, per packet, 10 cents. SINGLE VARIETIES. Finest Mixed. Price, per packet, 5 cents.

\section{Ageratum (Floss Flower.)}

PLUE PERFCTION. Color deep amethyst-blue. Price, per packet, 10 cents. GRANDIFLORA WHITE. Pure white. Price, per packet, 10 cents. MIXED. Consisting of white, light blue and dark blue. Price, per packet, 10 cents.

\section{Alyssum}

ITTLE GEM. They soon become one mass of white, remaining in full bloom from spring to fall. Hardy annual. Price, per packet, 10 cents.

SWEET ALYSSUM. Very fragrant; white. Hardy annual. Grows one-half foot high Price, per packet, 5 cents.

\section{Amaranthus}

JOSEPH'S COAT. Foliage red, green and yellow. Price, per packet, 5 cents.

PRINCE'S FEATHER. Brilliant foliage, red feather-like flowers; fine. Price, 5 cents per packet.

SUNRISE. The most brilliant of this brilliant family. The foliage is bronzy crimson, S per packet.

\section{Antirrhinum (Snapdragon)}

Nothing has been more improved in the past few years than the Antirrhinum, and they are now very popular and fashionable. Sown in spring they bloom from mid-summer until frost. They succeed best in light soil in a sunny position. They, are hardy perennials, but can be treated as annuals.

QUEEN VICTORIA. Purest white. Price, per packet, $10 \mathrm{c}$ QLACK PRINCE. Dark crimson. Price, per packet, 10c. LUTEUM. Sulphur yellow. Prlce, per packet, 10 cents. ROSEUM. Brilliant pink. Price, per packet, 10 cents.

FIRE KING. Orange and scarlet. Price, per packet, $10 \mathrm{cts}$. VENUS. Delicate pink. Prlce, per packet, 15 cts.

GIANT FLOWERED MIXED. A mixture of the newest varieties, having flower spikes nearly a foot long of most brilliant colors. Price, per packet, 10 cents.

\section{Quick Growing Vine Collection}

\section{Seven packets for 25 cents.} ORNAMENTAL GOURDS, SMALL VARIETIES. Chil. dren's favorite. Rapid climbers, small, brilliant colorec fruit.

BALSAM APPLE. A quick growing climber, with orna mental foliage and curious yellow fruits.

TRUE WHITE MOONFLOWER. Rapid growing annua climbing vines. Large white flowers.

COBEA SCANDENS. A fine, rapid growing climber, wit handsome, large bell-shaped flowers.

JAPANESE VARIEGATED HOP. Leaves variegate green and white.

HEAVENLY BLUE MOONFLOWERS. A very popula vine for covering large spaces.

BALLOON VINE. A rapid climber; seed vessels look lik miniature balloons.

A SUITABLE VINE FOR EVERY PURPOSE. TRY THIS FINE, LARGE COLLECTION. 


\section{The Cardinal Climber}

A Spléndid New Vine.

CRESTED MIXTURE. A mixture of the best sorts in shades of yellow, rose, erimson, scarlet and purple; very fine. Price, per packet, 5 cents.

DWARF MIXED. Fine dwarf varieties of Cockscomb. Price, per packet, 5 cents.

NEW PLUMED CELOSIA MAGNIFICENT. Each branch is tipped with a pointed head of richly colored bloom, which later broadens to a loose, plumy head of the most brilliant color. The colors embrace all shades of orange and yellow, salmon, scarlet and crimson. Price, per packet, 10 cents.

\section{Chrysanthemums Annual}

NORTHERN STAR (New Annual Chrysanthemums). The radiant white of petals, passing toward the center into a soft yellow, shows up strikingly against the bold black disk, and there is no doubt that this new Chrysanthemum will prove a real treasure to growers of flowers for cutting. Price, per packet, 15 cents.

EVENING STAR (Annual Golden Marquerite). Pure golden-yellow; in general appearance resembles the yellow Paris Daisy. Price, per packet, 10 cents.

BRIDAL ROSE (New Annual Chrysanthemum). Flowers like large double Daisies and are massed on the plants; fine for cut flowers. One of the best, bedding plants yet introduced. Price, per packet, 10 cents.

\section{Cypress Vine}

SCARLET. Per packet, 5 cents.

WHITE. Pure white. Price, per packet, 5 cents.

MIXED. Price, per packet, 5 cents.
A beautiful annual climber, the result of a cross between the Cypress vine and Scarlet Star Spomea which is far handsomer than either, with beautiful, deeply lanciniated foliage and literally covered with a blaze of circular fiery cardinal-red flowers from mid-July till frost. Price, 25 cents per packet.

\section{Cosmos}

MAMMOTH PERFECTION. White. This strain produces the largest flowers, perfectly white, beautifully shaped and in great masses. Fine for cutting. Price, per packet, 10 cents.

MAMMOTH PERFECTION. Pink. The largest flowers in rose-pink come from this seed. Color pure and brightvery fine. Price, per packet, 10 cents.

MAMMOTH PERFECTION. White. This strain produces crimson, very brilliant and striking. Price, per packet, $10 \mathrm{c}$

NEW MAMMOTH PERFECTION. Mixed. Flowers of unusual size in all shades of pink, crimson and white. Plants branch very freely, growing about six feet high, and are a mass of bloom above the fine green foliage. Price, per packet, 10 cents.

SUMMER FLOWERING DWARF COSMOS. Dawn. This variety is of compact growth, growing four or five feet high, and blooming in July, much earlier than the taller varieties. Flowers very large, white shaded to pink in the center. Price, per packet, 10 cents.

SUMMER FLOWERING, DWARF, MIXED. All colors. Price, per packet, 5 cents.

\section{Calliopsis or Coreopsis}

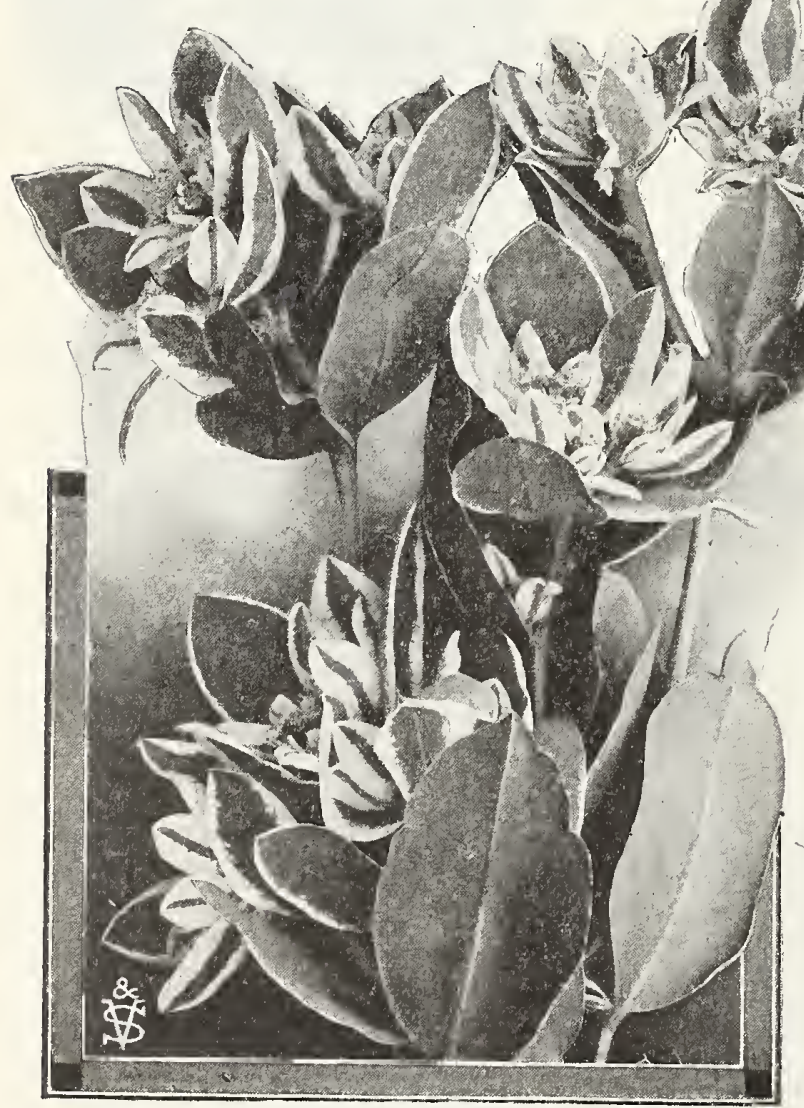

Snow on the Mountain.
Showy and free flowering annuals, blooming early and continuing until frost. The flowers are very showy, and excellent for cutting.

GOLDEN WAVE. A very showy sort with large yellow flowers, with dark brown centers. Price, per packet, 5 cents.

LANCEOLATA GRANDIFLORA. I a $\mathrm{r} g$ golden yellow. Price, per packet, 5 cents.

\section{Burbank's Shasta Daisy}

In growth the plants are as strong as a common field Daisy-very tall-well branched, with fine-cut foliage and huge white flowers, borne in profusion on long, stiff stems. The flowers are pure white with gold center; petals very long and center soft and velvety. Price, per packet, 15 cents.

MARGUERITE DAISIES. The old favorite variety of small white Marguerites. Price, per packet, 10 cents.

\section{Hollyhocks}

These are old-time favorites; beautiful for a background, lawn groups or for screens. Older forms will frequently flower from fall-sown seed, but require a good season to do so.

FINE DOUBLE. A percentage flower the first season from seed sown the previous fall; 5 to 8 feet. Bright red, maroon, bright rose, salmon, salmon-rose, scarlet, white, yellow and mixed.

ALLEGHENY MAMMOTH FRINGED. Very large, loosely formed, semi-double flowers, finely fringed. Early-sown seed will flower the first season.

Price, 20 cents per packet; three for 50 cents.

\section{Euphorbia Marginata or "Snow-on- the-Mountain"}

This native annual is quite popular as a garden plant on account of its showy appearance and ease of culture in almost any soil-even the poorest-if in a sunny location. It is of rank branching growth about 2 feet high. The foliage of light green being broadly margined with silvery-white, giving the effect-in miniature-of "Snow-on-the-Mountain."

Price, 10 cents pkt. 
TALL OR CLIMBING NASTURTIUM. Price, per packet, 10 cents; per ounce, 30 cents. BUTTERFLY. Of a clear lemon-yellow, marked on lower petals with a blotch of rich terracotta red.

CHAMELON. Flowers of various colors. On the same plant.

CAPRICE. Beautlfully mottled and blotched flowers, large and brilliant.

DARK CRIMSON. Deep velvety red, brown and brownish crimson.

FLAMMEUM. A heavy rich scarlet flower with brown markings.

FASHION. A pure ecru, overlald with a deep veining of old rose.

RED SPUR. Some are deep orange, spotted with blood red.

KING THEODORE. The deepest crimson variety.

MIDNIGHT. Dark green foliage. Flowers brownish red. Ounce, 20c.

MOON LIGHT. Pale straw-colored flowers.

SUNLIGHT. Beautiful yellow. Fnormous flowers, Ounce, 15 cents.

TWILIGHT, Salmon, suffused with rose. Ounce, 20 cents.

SALMON QUEEN. A rich, but, soft velvety shade of salmon.

\section{NEW GIANT-FLOWERED TALL}

This mixture contains all the varieties named of giant flowered Nasturtiums, besides a number of new varieties not named or described. For size of flowers and magniflcence of color, nothing can surpass these. This mixture is absolutely unequaled. Price, 10 cents per packet; 30 cents per ounce.

\section{Dwarf or Tom Thumb Nasturtiums}

Price, per packet, 10 cents; per ounce, 30 cents.

KING. Dark foliage and flowers of a rich velvety crimson. NEW DWARF GOLDEN MIDNIGHT. The contrast between the clear golden yellow foliage and extremely dark flowers is most remarkable.

NEW FRENCH CHAMELON. Flowers of the most diversified colorings and many brilliant markings on a single plant.

CARMINE KING. Dark foliage, rich velvety carmine flowers. PRINCE HENRY. Straw yellow, heavily suffused with rose. PEARL. Clear lemon yellow shading to faint primrose.

\section{SPECIAL MIXTURE OF DWARF NASTURTIUMS}

This mixture contains many different varleties of dwarf, or "Tom Thumb" Nasturtiums. Both this mixture and the "Special Mixture" of Tall Nasturtiums include varieties having blooms of a velvety texture new to the species, and some showing odd colors heretofore unknown. Price, per packet, 10 cents; per ounce, 30 cents.

\section{PETUNAS}

DOUBLE PETUNIAS. Seed of the double varleties of Petunias is very hard to obtain. We have secured some fine imported seed which will produce a large percentage of double flowers of the largest varieties in bright colors and tints. Price, per packet, 25 cents.

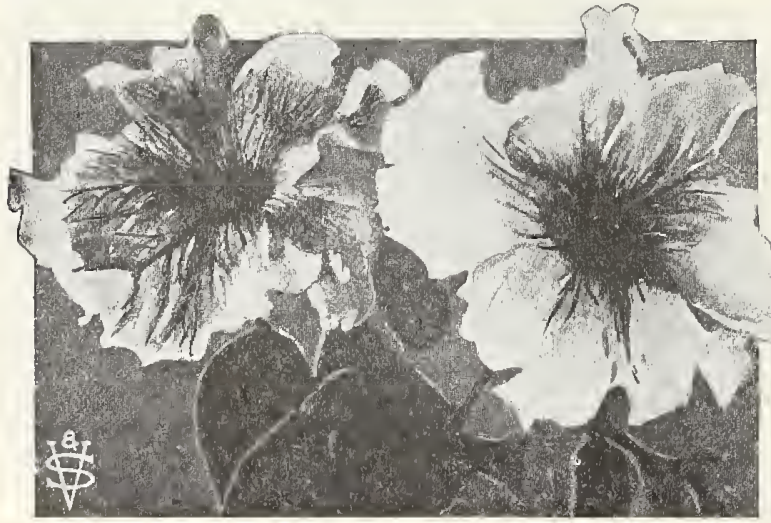

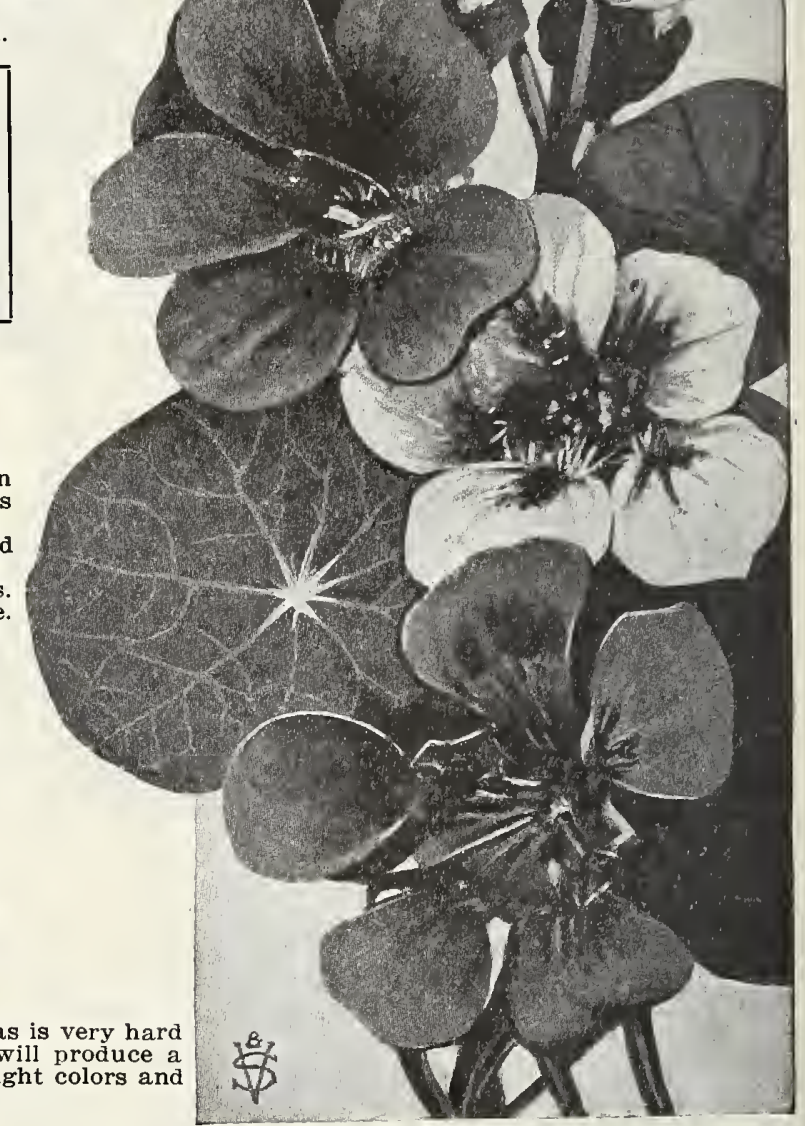

Dwarf Nasturtiums.

NEW GIANT FRINGED PETUNIAS.

GIANT FRINGED SCARLET, MIRANDA. Very beautifu flower of brilliant scarlet with fringed edge of delicate rose. Blossoms are immense and rich coloring. Price, per packet, $20 \mathrm{c}$. GIANT FRINGED MIXED. In great variety of color and with deeply fringed and ruffled edges. Price, per packet, 15 cents.

BLOTCHED AND STRIPED. A fine strain, flowers beautifully blotched, striped and marked Price, per packet, 10 cents. VENOSA, OR VEINED VARIETIES. Flowers of delicate shade of pink and white, veined from the throat to the edge of the petals. Price, per packet, 10 cents.

FANCY STAR. All shades of rose, crimson and magenta, strikingly marked with a bold, clear-cut white star. Price, per packet, 10 cents.

COUNTESS OF ELLSMERE. A beautiful flower of a most exquisite color, pure glistening pink like a La France Rose, with white throat. Price, per packet, 10 cents.

PURE WHITE. Fine, pure white flowers. Price, per packet, 10 cents.

FINE MIXED. Price, per packet, 5 cents. 


\section{Vestal's Beautiful Sweet Peas}

OUR NEW MIXED SWEET PEAS. This surpassing mixture includes the very finest and most distinct varieties now in cultivation. No strain offered will give better results and all who buy will be more than pleased.

\section{Vestal's "Prize" Mixture}

OF GRANDIFLORA, OR LARGE FLOWERING SWEET PEAS.

This superb mixture is our special pride. During the several years we have sold it, it has been our constant aim to improve and perfect it. The different kinds and sorts contained in this mixture are grown separately, so that we have an opportunity to choose only the largest and most beautiful varieties. These we mix ourselves in proper proportions for the most brilliant effect. It embraces the finest American and Eckford varieties, as well as the latest novelties, and will produce a great abundance of giant flowers of beautiful colors. Some are edged, mottled, blended, flaked and striped. Without exception, this is the very finest mixture it is possible to make. We recommend that our customers buy these seeds by weight and plant liberally. Price, per packet, $10 \mathrm{c}$; ounce, $20 \mathrm{c}$; pound, $\$ 2.00$.

\section{Large Flowering Sweet Peas}

(Improved.)

We offer below a list of the best varieties of Sweet Peas now grown. In our selection we have the clearest, most distinct shades-that stand in the sun-and do not fade quickly when cut. Get a splendid supply of new seed, as nothing can be more satisfactory. Sow seed as early in the spring as ground can be worked, so that plants get an early start. Cut blooms as fast as they appear, which prevents them seeding. Seeding stops the blooming. Price, per pkt., 5 cents; seven pkts. for 25 cents.

DOROTHY ECKFORD The grandest pure white yet introduced. Extra large flowers, beautiful shell shape; purest white. Vines produce an enormous amount of bloom

JANET SCOTT. This might almost be called a new shade of rich pink. The unusual size of the wings give the flower an normous size.

SUNPROOF SALOPIAN. Finest, most brilliant scarlet, never changing colors.

KING EDWARD VII. Most gorgeous large flowers; rich blood-scarlet; new and unrivaled.

BLACK KNIGHT. Large flowers of the finest texture; a bright shining reddingmaroon, very striking. A very desirable color.

SYBIL ECKFORD. Delicate blush pink and lemon yellow, changing to pink.

ST. GEORGE. Rich salmon-orange; very brilliant.

LOTTIE ECKFORD. Large blossoms, shaded light blue on white ground, edged purple; new.

FLORA NORTON. A beautiful rich avender; one of the most pleasing thades; very large flower.

CAPT. OF BLUES. A grand flower of bright indigo-blue; the wings are a ighter shade of blue, extra large lower.

\section{Vestal's Special Blend Spencer Sweet Peas}

If Planted Now They WIII Blossom Forth in a Riot of Brilliant Beauty During May and June.

Among recent sweet pea novelties there has appeared nothing finer than the new race of Orchid Flowering or Countess Spencer Peas.

They are distinguished for their gigantic size-usually measuring two inches across. The bold, erect standards, which are uniformly waved, crimped and fluted in exquisite fashion, the charming blending of harmonious colors, the exceedingly long stems, which make them excellent for cutting; the great profusion of flowers and the large number on the stems, usually three or four, make this type so superior in every way that we believe it is certain to supersede the old varieties.

The Sweet Peas in our SPECLAL SPENCER BLEND are made up of the finest named Spencer varieties and range in color from the purest white to shades of pink, lavender, blue, yellow and crimson, and are just the kind to make your garden a success.

It is the very best blend possible to produce and will surely delight all who want a great variety of colors.

Price, per packet of 110 to 125 seed, 20 cents; per ounce, 50 cents, postpald.

CULTURE - The culture is very simple. Plant seed 3 to 4 inches deep in the most convenient place you happen to have, very early in the
spring-just as early as possibleFebruary, March or April-according to the season and locality. Keep the ground loose and mellow; give the young plants some support to climb on-wire netting, twine or brush. Keep the flowers picked off as fast as they open (this is very important), and they will bloom abundantly for weeks.

Extra Early Flowering Sweet Peas

Any of the following varieties of Sweet Peas may be brought into flower from forty to sixty days after planting the seed. These varieties are called winter blooming kinds by florists who grow them in greenhouses. They also are used for the earliest outdoor blooming. Per packet, 15 cents; per ounce, 50 cents.

BURPEE'S EARLIEST'WHITE. Flowers purest white. An abundant bloomer, flowers appearing forty-five days after seed is planted.

BURPEE'S EARLIEST OF ALL. Blooms fortyfive days after seed is planted in the ground. Color light pink and white; dainty.

MRS. F. J. DOLANSKY. This early-flowering variety is of strong, vigorous growth. Flowers of a bright pure pink.

MRS. CHAS, H. TOTTY, Flowers of a beautiful sky-blue or light lavender. Unusual size, lovely color

LEMARQUIS. Is an early flow ering type, navy-blue; very fine. EARLIEST SUNBEAMS. A very desirable variety for early flowering. The flowers are of rich primrose color, generally borne three on a strong stem.

EXTRA EARLY FLOWERING MIXED SWEET PEAS. Per packet, 15 cents; per ounce, 50 cents. 
Price, per packet, 15 cents; per ounce, 50 cents, for any named Spencer Sweet Pea.

\section{Asta Ohn}

Pinkish lavender, the wings showing a little more clear lavender. Good size and best Spencer form.

\section{Blanche Ferry Spencer}

The popular old "painted lady" pink and white Sweet Pea in magnificent new form.

\section{Beatrice Spencer}

White, tinted with soft pink and buff on standard, while the wings have prominent blotches, of a brighter pink near base.

\section{Countess Spencer}

The original Spencer type Sweet Pea and to the present day one of the best pinks. The color is bright clear pink on white ground. The pink deepens towards edge of standard. Standard and wings beautifully waved. Strong grower and bears numerous fours.

\section{Florence Nightingale}

Clear lavender with a little mauve color in flower.

\section{Florence Morse Spencer}

Beautiful light pink, deepening towards edges. Very large, open, wavy form of the best Countess Spencer type, with long stems and four blossoms to the stem. Perhaps better described as a light, pink-edged Countess Spencer. Our new strain of it comes perfectly true.

\section{George Herbert}

Bright rosy carmine of large size and best Spencer form.

\section{Helen Lewis}

Standard orange, wings rosy salmon. Large, wavy. One of the earliest Spencer varieties and still a favorite.

\section{King Edward Spencer}

Rich crimson, waved. Flowers are large and of fine Spencer form. It is a vigorous grower and is a good variety for exhibition and for garden.

\section{King White}

A superb white. Purity of whiteness and vigor, form and size remarkable, substance wanting. This is a grand Pea for dry climates but is too thin where rains are frequent during blooming time.

\section{Othello Spencer}

The popular shade of deep maroon, very rich and unusual immense flowers much crinkled. One of the varieties of the Sweet Pea family.

\section{Primrose Spencer}

Both standard and wings are of beautiful, soft Primrose or creamy yellow color. Flowers are very substantial and in a class of their own in both color and size.

\section{Royal Purple}

The best Purple Spencer Sweet Pea. As the name suggests the color is near "Royal" Purple. The color deepens and improves as the flowers age which is a good point in a purple variety. One of the most distinct and successful Spencer introduced. A strong grower and very floriferous, excellent flower.

\section{Hardy or Everlasting Sweet Peas}

A splendid vine, bearing blossoms just like Sweet Peas; all colors, on good, long stems. Fine for covering fences, lattices, etc. Perfectly hardy. Mixed, all colors, price, $10 \mathrm{c}$ per packet; $50 \mathrm{c}$ per ounce.

\section{Senator Spencer}

The combination of color in the flowers is charminga deep claret or chocolate, striped and flaked on a ground of light heliotrope. Both standard and wings are extra large, wavy and drooping. Flowers are usually borne four to the stems.

\section{Vermilion Brilliant}

Scarlet, waved. To date this is one of the best Scarlet spencer. The color is a rich scarlet but has some crimson in it. It is a vigorous grower for a scarlet and flowers are of good form. A good number of four bloomed sprays are produced.

\section{Wedgewood}

Wedgewood is a unique shade of lovely light blue. The flowers, of good size and substance, are well waved in both standard and wings; they are borne almost uniformly in four-flowered sprays upon long stout stems.

\section{White Spencer}

This stock was the first waved white variety. Is conceded to be the best.

\section{Yarrawa}

The flowers are exquisitely waved and when well grown average two and one-half inches in diameter. They are produced usually in fours on extra long, strong stems. The color is a bright rose-pink with a clear, creamy base, the wings being slightly lighter in tone. Yarrawa, grown out doors, begins to flower fully two weeks earlier than the summer Spencers.

\section{Hercules}

A magnificent soft rose-pink of truly giant proportions, un doubtedly the best pure pink. A flower of great substance; the broad spreading and beautifully waved standard frequently measures two and one-half inches in diameter.

\section{Illuminator}

Pronounced the most glorious Sweet Pea ever seen. A rich cerise-salmon with an indication of bright orange which scintillates and glistens under-bright sun. Flowers four to a stem, beautifully waved and large.

\section{Dainty Spencer}

White, with exquisite rose-pink edges. Of uniformly large size and elegant shape.

\section{Margaret Atlee}

A new shade of pink unlike any other variety, being a glowing pink on a cream ground. The flower is of true Spencer size and form and the plants so vigorous that many "duplex" or double flowers are produced.

\section{Fiery Cross}

This is considered the finest scarlet in existence, of perfect spencer type and a wonderfully brilliant color.

\section{Captain of the Blues}

A large clear purplish blue full spencer size possessing bluish purple wings with veins of rosy purple.

\section{Mrs. Cuthbertson}

An improved Apple blossom, a bi-color, having rose pink standard with pure white wings, very large and fine. The best of the bright pink and white Spencers.

\section{Leaflet "How to Grow Sweet Peas"}

includes new information on the subject, and how the English grow big ones for exhibition. Free to Customers when asked for. 


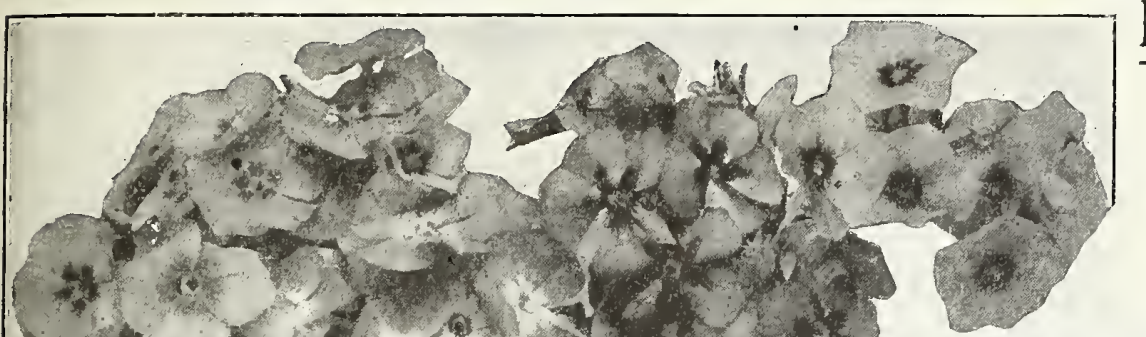
so until frost. They may be used in a variety of ways, such as a carpet to beds of roses, in beds or borders, that they show to best advantage, Price, per packet, 10 cents; two packets, 15 cents; five packets, 30 cents.

CARNEA. Delicate rosy-flesh color.

SNOW STORM. Large flowering, pure white,

GLOWING CRIMSON. Beautiful shade of brilliant crimson. BRILLIANT ROSE. True bright pink.

COCCINEA. Bright scarlet

GOLDEN GLOW. Beautiful rich yellow.

VIOLET. Dark violet or purple

NEW PHLOX "SALMON STAR-EYED." (Salmanae Stellante.) A pleasing addition to the dwarf Phlox so universally liked for their vigorous growth and abundant blooms. The flowers, borne in immense trusses, are unusually large and of a most pleasing rosy-salmon with a clear white eye. Price, per packet, 15 cents.

STAR-EYED (Stellatas), mixed colors. Grand large flowers; beautiful colors, each flower having a white star eye. Price, per packet, 10 cents.

STRIPED MIXED. Pure white, with brilliant colored stripes. Price, per packet, 10 cents.

STARRED AND FRINGED PHLOX. Most distinct and striking. The flowers have a star-like appearance, white margins border the edges of the petals. Price, per packet, 10 cents.

\section{Phlox Grandiflora, Mixed}

We believe the Grandiflora mixed to be the grandest strain ever introduced. It grows neat and compact; flowers of uniform size, produced in greatest profusion. The colors embraced in this mixture show a wonderful diversity, comprising 28 distinct shades and markings. Price, per packet, 5 cents; seven packets for 25 cents.

\section{Zinnias}

No flowers are more easily grown from seed in the open ground, and few bloom so continuously throughout the entire summer. Those acquainted only with the old-time Zinnias will be surprised at the perfection to which the newer strains have attained.

\section{Mammoth Flowered Zinnias.}

MAMMOTH PINK. The largest and handsomest Zinnia known; flowers are deep pink; very striking. Price, per packet, 10 cents.

MAMMOTH SNOW QUEEN. Very large pure white flowers, which re fine for cemetery planting. Price, per packet, 10 cents.

MAMMOTH GOLDEN QUEEN. Large flowers of pure, clear lemonyellow. Price, per packet, 10 cents.

MAMMOTH CRIMSON JACQUEMINOT. Large flowers of velvety texure and rich crimson shade; extra fine, Price, per packet, 10 cents.

MAMMOTH MIXTURE. A mixture of the large-flowering type, in which are the white, yellow, gold, scarlet, crimson and purple. Price, ser packet, 10 cents.

SPECIAL OFFER. One packet each of the Five Mammoth Zinnias or 40 cents.

Other Types of Zinnias.

CRESTED AND CURLED. Curiously twisted petals, giving the flower he appearance of a small Japanese Chrysanthemum. Price, per packet, cents.

ZEBRA MIXTURE. A fine mixture of all the striped sorts; very inique and interesting. Price, per packet, 5 cents.

LILLIPUT MIXTURE. A fine class of free-flowering Zinnias, with mall, perfect flowers; fine for cutting, as they bloom most abundantly. 'rice, per packet, 5 cents.

BUTTON, RED-RIDING-HOOD. This little gem grows but a foot high; f compact form, and covered the entire season with little button-like, ntense scarlet, very double flowers not over an inch across; as a border is highly effective. Price, per packet, 10 cents.

SPECIAL OFFER. One each of the above four types, crested and urled, Zebra, Lilliput and Button, for 20 cents.

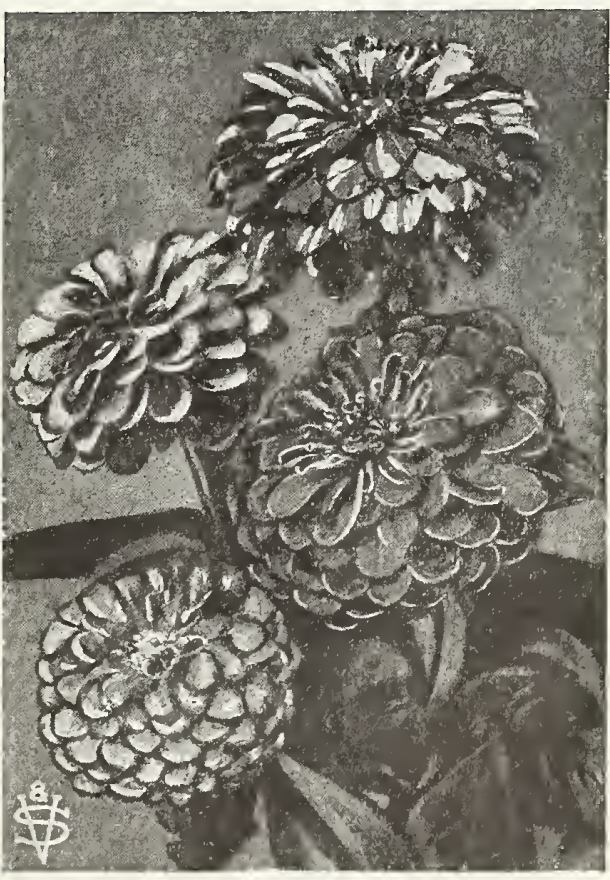

ZInnias. 


\section{Vestal's Mammoth Flowering Verbena Seed}

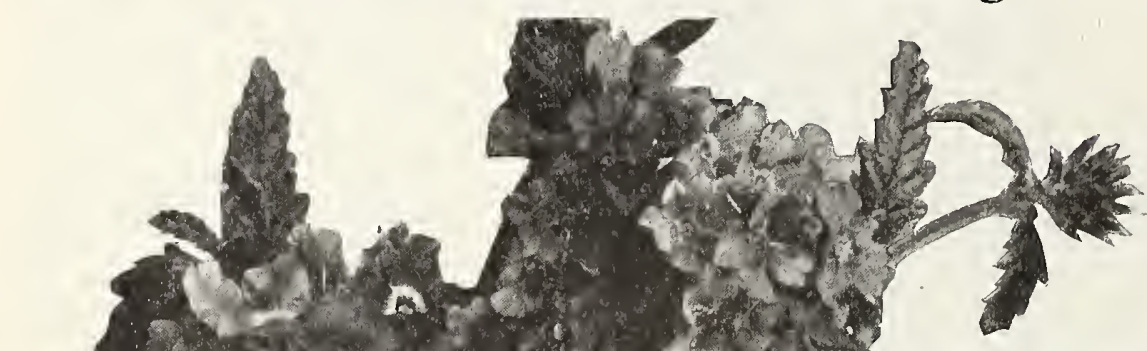

seed than from cuttings, being more (

MAMMOTH WHITE. Flowers of unusual size, of snowy whiteness, excellent for cemetery bedding. Price, per packet, 10 cents.

MAMMOTH SCARLET DEFIANCE. A variety with very small leaves and large head of brilliant fiery scarlet. Price, per packet, 10 cents.

MAMMOTH COERULEA. Beautiful deep blue, very large florets marked with white eye. Price, per packet, 10 cents.

MAMMOTH PINK MIXTURE. Beautiful shades of pink, cerise and cherry; in very large heads of handsome bloom. Prlce, per packet, 10 cents.

MAMMOTH ITALIAN STRIPED. We offer here a mixture of the best striped Verbenas, which will come in a great variety of colors, such as white and red, white and pink, white and purple, ețc. Price, per packet, 10 cents.

VESTAL'S MAMMOTH MIXTURE. This is a fine mixture of the mammoth flowered Verbena which will produce heavy trusses of bloom in which the individual fiorets are of unusual size. The colors are all that are known in the Verbena family. Price, per packet, 10 cents

SPECIAL OFFER. One packet each of the Six Mammoths for 50 cents.

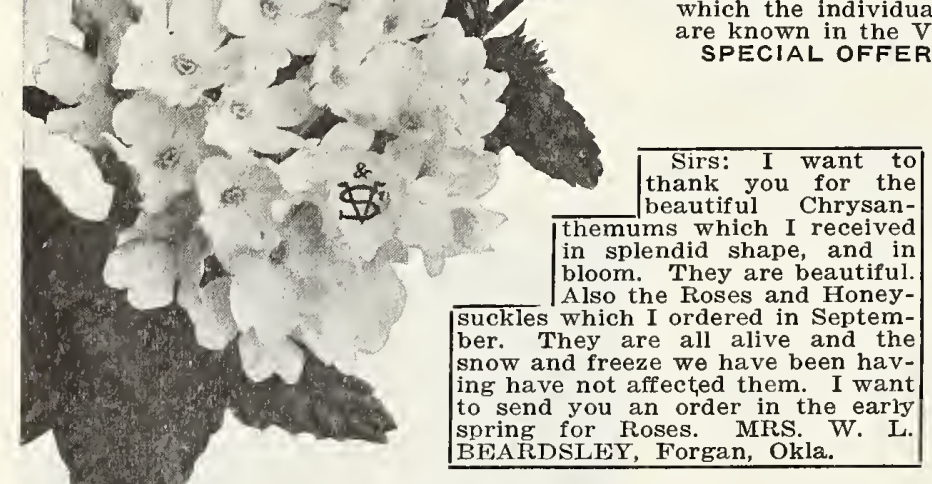

Salvia

The Salvia is now a standard bedding plant, and well deserves its honor. Seed is best started under glass, though self-grown seed frequently comes up in great numbers where a bed of these plants has Geen the previous year.

SPLENDENS. Large, scarlet; exceedingly showy and useful for cutting and for ornamental beds. Price, per packet, 10 cents.

\section{New Salvia \\ "Scarlet Dragoon" or Fireball}

A new dwarf, extra early flowering variety. The plant itself rarely grows over a foot high, while the erect spikes of brilliant scarlet flowers average a foot in length, making the total height of the plant when in full bloom between 20 and 24 inches by about the same in diameter. This new variety is most highly valued because it begins to bloom many weeks before the older sorts; continues a veritable "ball of fire" throughout the summer and fall. Price, per packet, 20 cents.

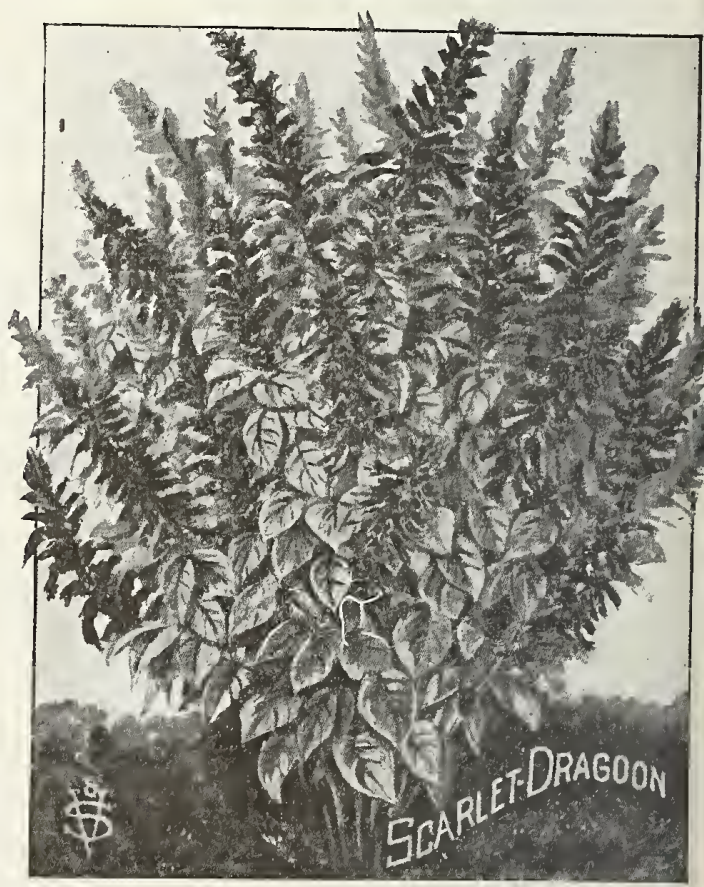

\section{Vinca Rosea (Madagascar Periwinkle.)}

Ornamental free-blooming plants. Seed must be sown early and plants will bloom first summer. Can be taken up in Iall like Chrysanthemums, then potted and kept in bloom through winter.

ALBA. White with rose eye Packet 10 cents.

ALBA PURA. Pure white. Packet, 10 cents.
ROSEA. Rose with dark eye Packet, 10 cents. 


\section{General List of Vestal's Superb Flower Seeds}

ABUTILON (Flowering Maple). Free flowering plant with various colored beautiful drooping bell-shaped flowers. Mixed, 10c per pkt.

BALSAM PEAR. The same as Balsam Apple except in fruit, which are six inches and over in length, orange colored. Fine medicinally. Price, 5c pkt.

BRYONOPSIS LACINIOSA. Annual climber with pale green foliage and showy fruit, first green striped white, turning when ripe to bright scarlet striped white. Price, 5c per pkt.

BROWALLIA. Favorite bedding plant, producing beautiful blue flowers during summer and autumn months. Price, $5 c$ per pkt.

CANNAS. Best mixed sorts of all colors, scarlet, pink, yellow and variegated. Price, 5c per pkt.

CENTAUREAS. Cyanus. Cornflower, Blue Bottle, Ragged Sailor). Flowers blue, pink or white. Fine mixed, 5c per pkt.

Double Cyanus (Double Cornflower). A handsome flower. Mixed, 5c pkt.

CANDYTUFT. Fine border plant similar to sweet Alyssum. Rose Cardinal. Bright rose; fine for borders or cutting. Prlce 5c pkt.

Dark CrImson. Richest dark shade. Prlce, 5c pkt.

Empress. Grows larger trusses of pure white flowers. Fine for cemetery use. Price, 5c pkt.

Mixed. All shades known in Candytufts. Prlce, 5c pkt.

COBOEA SCANDENS. (Cups and Saucer VIne). Purple. Price, pkt. 10c.

White. Price, 10c per pkt.

CAMPANULA (Canterbury Bells). Double. Mixed. 5c pkt. Single. Mixed. $5 c$ per pkt.

CALENDULA (Pot Marigold). Favorite. Beautiful double giant lemon yellow flowers striped white. $5 \mathrm{c}$ per pkt. Orange KIng. Mammoth flowers of rich orange yellow flowers. $5 \mathrm{c}$ pkt.

CLARKIA. Single mixed. All colors, 5c pkt.

Double Mixed. All colors, 5c pkt.

COWSLIP (Primula Veris). A beautiful hardy spring flowering perennial; flowers of different colors such as yellow, brown edged yellow, etc. Very fragrant. Prlce, $5 c$ per pkt.

COLEUS. Fine Mixed. Prlce, 10c per pkt.

CANARY BIRD VINE. A beautiful rapid climber, the charming little canary colored blossoms bearing fancied resemblance to a bird with its wings half ex. panded. Price, 5c per pkt.

CLEOME PUNGENS (Giant Spider Plant). Plant grows 4 to 5 feet with flowers bright rose color. Seed pods resemble a many legged spider.

DELPHINUM (Hardy Larkspur). Gold Medal Hyblrds. Spikes 2 to 3 feet of large flowers mostly blue shades. Prlce, 25c per pkt.

Coelestlnum. Exquisite celestial blue with white centers. A beautiful variety of new and most pleasing shade. Prlce, 25c per pkt.

DIANTHUS or Sweet clove Pinks. Nobllis. Improved varieties of the Single flowering Japan Pinks. Colors vary from white to dark red. Price, $10 \mathrm{c}$ per pkt.

Double Snowball. Pure double white flowers, very full and deeply fringed like a Carnation. Price, $10 \mathrm{c}$ per pkt.

Double Imperial Pink. Double large flowers of pink shades. Price, 10 cents.

Double Fireball. Rich shades of double crimson and scarlet. Prlce, 10c.

Double Fringed Excelsis. A new double flowering Japanese Annual. Price, 10c.

New Double Pink Count Kerchove. Petals dark blood red, marked with velvety black spot. Large double fowers. Price, 15c pkt.

Mixed. Best mixed varieties. Price, $5 \mathrm{c}$ per pkt.

DATURA (Trumpet Flower). Cornucopia (Horn of Plenty). The flowers average 8 inches long by 5 across. French white inside, purple outside; fragrant. Price, $10 \mathrm{c}$ pkt

DIGITALIS (Foxglove). Beautiful hardy perennial. Flowers are borne on long spikes.

Gloxiniaflora Mixed. This is the finest strain, rich in color and splendidly mottled. Price, $10 \mathrm{c}$ per pkt.

Monstrosa Mixed. Best mixture of large flowering type. Price, 10c pkt.
FORGET-ME-NOTS. Turquoise. Large blooms clear tur quoise blue. Price, $10 \mathrm{c}$ pkt.

Mixed Colors. Containing white, pink, pale and deep blue. Price, 5c pkt.

DAHLIAS. Single Giant Perfection Mixed. Flowers very large and perfect. Price, $10 \mathrm{c}$.

Single Cactus Mixed. The petals are curiously quilled, giving the flower the look of Cactus blooms. All shades. Price, 10c.

Single Striped and Spotted. Flowers distinctly striped with slashes of contrasting color to thickly spotted. Price, $10 \mathrm{c}$ pkt.

Double Pompon Mixed. This type of Dahlias is perfectly double and round. Blooms freely. Price, 20c pkt.

Double Cactus Flowered Mixed. Flowers very full and double petals curled and twisted resembling Cactus blooms. Mixed colors. Price, 20 cents.

Double Premium Mixed. Finest mixture of the large double flowering varieties. Price, $15 \mathrm{c} \mathrm{pkt.}$

ESCHSCHOLTZIA (Calif. Poppy). Flowers in all colors resembling Poppies. Price, 5c pkt.

MIxed. $5 \mathrm{c}$ pkt.

Burbank's Carmine KIng. Flowers clear carmine crimson. Blooms freely and something new and distinct. Price, $15 \mathrm{c}$ pkt.

FEVERFEW. A free flowering plant, bearing clusters of small double white flowers. Fine for cut flowers. Price, 10c pkt.

GAILLARDIA (Blanket Flower). Very showy free flowering plants that are quite hardy and are very easily raised from seed.

Picta Lorenziana. Double flower beautifully formed, maroon tipped, with yellow and crimson combination. Price, 5c pkt.

Grandiflora Single. Beautifully marked petals in brilliant colors. 5 cents pkt.

GYPSOPHILA (Baby's Breath). Small star-like flowers and borne in feathery-like sprays. Fine for boquets and cutting.

Elegans. White and Rose mixed. Price, 5c.

Convent Garden. Improved strain with long sprays of flowers. Prlce, $5 \mathrm{c}$ pkt.

GODETIA (Satin Flower). Very attractive plant for gardens. Gloriosa. Blood red flowers. Price, 10c per pkt.

Choice Mixed. All colors. Price, 10c pkt.

GOURDS. Nest Egg. The Gourds are round, resembling eggs. Price, 5c pkt.

Dish Rag or Sponge. With long green fruit often used for wash rags or bathing purpose. Price, 5c pkt.

Small Mixed. Varieties. Gooseberry, apple, lemon, pear shaped, etc. 5c pkt.

Large Varieties. Dipper, sugar trough, club, bottle shaped, etc. $5 \mathrm{c}$ pkt.

HELIOTROPE. Mixed many varieties. Price, 10c pkt.

HIBISCUS (Marshmallow). Crimson eye with white centers. Price, 10c pkt.

HYACINTH or Jack Bean. Beautiful climbing vine. Dayllght. White flower. 10c pkt.

Darkness. Flowers lavender purple. Price, $10 \mathrm{c}$ pkt. Mixed. White pink and purple flowers. Price, 10c pkt.

HOP. Japanese variegated. Strong growing climber, variegated leaves. $5 \mathrm{c}$ pkt.

KOCHIA SCOPARIA. Summer Cypress or Mexican Burn ing bush. Fine for borders to Cannas, used extensively for hedges. Price, 10c pkt.

LANTANAS. Very profuse bloomers. Mixed all colors. 5 c pkt.

KUDZU VINE. Japanese Hardy climbing vine, flne where quick shade is desired. Hardy everywhere. Price, 10c pkt.

LAVENDER. Very fragrant flowers. Plant too well known for description. $5 \mathrm{c}$ pkt.

LOVE IN A MIST (Negelia). Compact free flowering plant; hardy annual. $5 \mathrm{c}$ pkt.

LINUM (Coccineum Scarlet Flax). Fine border plant, foll age fine and delicate with flowers of scarlet crimson, of long duration. 5c pkt. 
LOBELIA. Bushy plant, with masses of bright winged shaped flowers.

Compacta. Mixed colors. Bush form suitable for borders. $5 c$ pkt.

Gracillis. Fine mixed. Climbing varfety suitable for boxes and baskets, all shades of blue. Price, $5 \mathrm{c}$ pkt.

PYRETHRUM. Foliage plant for borders of ornamental beds.

Aureum. (Golden Feather). Bright golden foliage. Price, $10 \mathrm{c}$ pkt.

Selaginoides. Leaves very finely cut. Price, $10 \mathrm{c} \mathrm{pkt.}$

MIGNONETTE. Finest large-flowering.

Red Goliath. New. Price, pkt. 10c.

The Machet. Deliciously scented. Price, pkt. $5 \mathrm{c}$.

Giant White. White florets. Price, 5c.

Common Sweet. Price, pkt. 5c.

NICOTINA SANDERAE. New Carmine Tuberose-flowered Tobacco. 10c pkt. Grows about 2 feet high; handsome carmine-red flowers; very fragrant.

PLATYCODON (Hardy Chinese Bell Flower). Flowers are bell shaped and come in all colors. Price, 5c pkt.

PORTULACA, or Sun Moss. Does best in light sandy soil and sunny situation.

Double Mixed. Flowers perfectly double; fine for bedding. Price, 10c.

Single Mixed. All colors, profuse bloomers. Price, 5c pkt.

PASSION FLOWER. A very beautiful flowering vine easily raised from seed. Too well known for description. Price, 10c pkt.

PENNESTUM. Ornamental grasses; $2 \frac{1}{2} \mathrm{ft}$. high, with beauţiful plumes. Pkt., $5 \mathrm{c}$.

RUEPPELIANUM. Purple fountain grass, with purple plumes. Pkt., 5c.

LONGISTYLUM. Silver-plumed grass. Like the purpleplume grass, only silver white plumes. Price, 5c pkt.

POPPIES. Snowdrift. Snow-white flowers. 5c pkt.

Fairy Blush. Delicate blush pink. 5c pkt.

Golden Gate. Flowers are variegated or changeable colors. 5c pkt.

Cardinal. Double cardinal scarlet flowers. 10c pkt.

Shirley Mixed. Single and Double, flowers 4 inches across. 5c pkt.

Double Carnation Flowered. Improved strain, distinct, shades and colors; double beautifully fringed petals. 5c pkt.

Paeony Flowered Mixed. Double flowers like a Paeony. $5 \mathrm{c}$ pkt. The set of 7 varieties above for $25 \mathrm{c}$.

Glant Oriental. (Hardy variety). A charming summer flowering plant, deep crimson flowers, with black spot on each petal; very showy plant for the garden. Price, 10c pkt.

Iceland Mixed. Hardy variety. Very beautiful with orangescarlet yellow and white flowers. Price, 10c pkt.

SALPIGLOSSIS (Velvet Plant). Blooms in the fall, having funnel shaped flowers. Very showy border plant. Grandiflora mixed, 5c pkt.
SCHIZANTHUS. Plants compact growth, $11 / 2 \mathrm{ft}$. high with butterfly-like flowers; very showy. Price, 25c pkt.

STOCKS (Gilliflower). Very fragrant flowers, fine for cutting.

Perpetual White. Price, 10c per pkt.

Perpetual Mixed. Price, 10c pkt.

Large Flowered Dwarf German Mixed. 5c pkt.

STRAWFLOWERS (Everlasting). Batchelor's Button. Flowers globed shaped, very double, white, pink rose, purple and striped; very good bloomers. Price, $5 \mathrm{c}$ per pkt.

Helichrysum. (Strawflower fine for winter boquet,s). Cut before the buds expand. Mixed colors. 5c pkt.

Rhodanthe. The lovely everlasting either in the garden or for winter boquets; flowers, white rose or crimson. 5c per pkt.

SUNFLOWER. Russian Giant. Enormous double flowers of deep golden yellow. 5c pkt.

Orion. Petals curled and twisted like a Cacti Dahlla; fine for cutting. Price, 10c pkt.

Double Miniature. Dwarf plants with double round miniature pompon shaped sunflowers. Price, 5c pkt.

Red Sunflower. Something new, flowers showing the red color so much desired. Petals straight and flat, which are colored in the various shades of red with distinct circle of yellow and purple around the dark disk. Price, 25c per pkt.

Chrysanthemum Flowered. Flowers entirely double, resembling in form a double chrysanthemum. Color, bright yellow golden color. Price, 15c.

SWEET WILLIAMS (Dianthus Barbatus). Double MIxed. All colors from white to deepest crimson. Price, 10c.

Single Mlxed. All shades of fine single varieties. Price, $5 \mathrm{c}$ pkt.

Double Midnight. A mixture of the darkest richest crimson shades. 10c pkt.

THUNBERGIA (Black Eyed Susans): Rapid growing climbers, fine for vases, rustlc work and for twining among heavy growing vines. All shades of colors. 10c pkt.

SCABIOSA (Morning Brides). Maxima Plena. Double large flowered type, very fragrant and fine for garden decorations. Annuals, $1 \frac{1}{2}$ to $2 \mathrm{ft}$. high. Price, $10 \mathrm{c} \mathrm{pkt.}$

WILD CUCUMBER. Rapid growing climber reaching about $30 \mathrm{ft}$. in one season. Has beautiful clusters of sweet scented flowers, with ornamental prickly seed pods. Price, 5c per pkt.

LARKSPUR (Delphinums Annual). Giant Hyacinth Flow. ered. New from Germany. All colors. Price, 10c pkt.

Double Tall Stock Flowered. Spikes of double flowers, 18 inches long. Very beautiful. Best mixed colors. 10c pkt.

FOUR O'CLOCK. Mixed colors. 5c per pkt.

DUSTY MILLER. Silver Leaved Centaurea. $10 \mathrm{c}$ per pkt. MORNING GLORY. Double White Tassel. Price, 10c per pkt. WALL FLOWER. Delicious, fragrant flowers on massive spikes. Fine for beds or borders.

Double Mixed. Price, $10 \mathrm{c}$ per pkt.

Single Mixed. 5c per pkt.

\section{Surprise Collection Flower Seed \\ TWENTY PACKETS FOR SEVENTY-FIVE CENTS.}

In this collection we have included all of the most popular and best flowering annuals. The seeds of each flower are of the best varieties, and will give a fine array of flowers for a little money.

SWEET PEA. A big packet.

LARKSPUR. Very sweet.

ALYSSUM. Very sweet.

SCABIOSA. Mixed double.

CLOVE PINKS. All shades.

COSMOS. Mammoth blooms.

MIGNONETTE. Sweetest scented.
MORNING GLORY. A large packet.

ASTER. Largest flowering.

NASTURTIUMS. Rich shades.

PHLOX. Brightest colors.

POPPY. Very showy.

PETUNIA. Best mixed.

GAILLARDIAS. All shades.
PANSY. Mammoth flowers. ZINNIAS. Giant flowered. CANDYTUFT. Every shade.

SWEET WILLIAM. Richest colors. CENTAUREA. Largest flowering.

VERBENA. Fine flowered. 


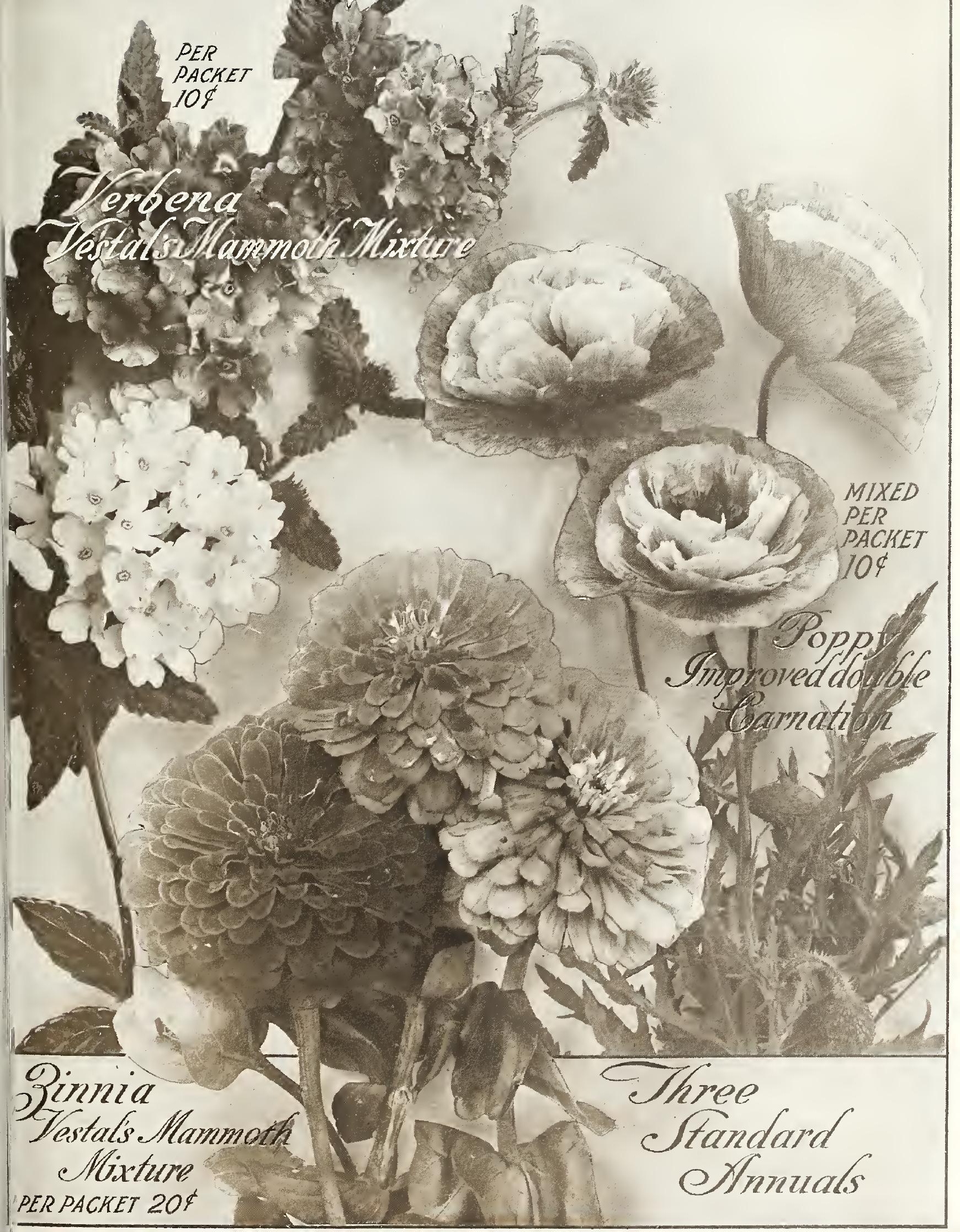


